\title{
Aboveground and belowground response of European beech to drought: field studies and experiments
}

\author{
Dissertation \\ zur Erlangung des Doktorgrades \\ der Mathematisch-Naturwissenschaftlichen Fakultäten \\ der Georg-August-Universität zu Göttingen
}

vorgelegt von

Ina Christin Meier

aus Göttingen

Göttingen 2007 
D 7

Referent: Prof. Dr. Christoph Leuschner

Korreferent: Prof. Dr. Frank Thomas

Tag der mündlichen Prüfung: 3. Mai 2007 


\section{This dissertation is substantiated by the following publications}

1 Leaf size and leaf area index in Fagus sylvatica forests: competing effects of precipitation, temperature and nitrogen availability

Meier IC · Leuschner Ch

Ecosystems (2008, accepted)

2 The belowground drought response of European beech: fine root biomass and carbon partitioning in 14 mature stands across a precipitation gradient

Meier IC · Leuschner Ch

Global Change Biology (2008, accepted)

3 Genotypic variation and phenotypic plasticity in the drought response of the fine root system of European beech

Meier IC $\cdot$ Leuschner Ch

Tree Physiology (2008) 28 297-309

\section{Additional publications}

4 Climatic data, tree ring records

Meier IC

In: Encyclopedia of Global Warming and Climate Change (under review)

(eds. Philander SG, Golson JG). Sage, Thousand Oaks.

5 On the niche breadth of Fagus sylvatica: soil nutrient status in 50 Central European beech stands on a broad range of bedrock types

Leuschner Ch $\cdot$ Meier IC $\cdot$ Hertel D

Annals of Forest Science (2006) 63 355-368

6 Nutrient return with leaf litter fall in Fagus sylvatica forests across a soil fertility gradient

Meier IC · Leuschner Ch · Hertel D

Plant Ecology (2005) 177 99-112 


\section{Table of contents}

$\begin{array}{ll}\text { Chapter } 1 & 1\end{array}$

General introduction

Chapter 2

Materials and methods

Chapter 3

Leaf size and leaf area index in Fagus sylvatica forests:

competing effects of precipitation, temperature and nitrogen availability

Chapter 4

The belowground drought response of European beech: fine root biomass and carbon partitioning in 14 mature stands across a precipitation gradient

Chapter 5

Genotypic variation and phenotypic plasticity in the drought response of the fine root system of European beech

Chapter 6

Synopsis

Summary

Zusammenfassung

References

Appendix

Danksagung

Curriculum Vitae 
Chapter 1

General introduction 


\section{Background}

\section{Global climate is changing}

The latest assessment report of the Intergovernmental Panel on Climate Change on the impacts of human-induced climate change reconfirms that global atmospheric concentrations of greenhouse gases have increased markedly since 1750 as a result of human activities, and cause radiative forcing (IPCC 2007). The warming of our climate system is unequivocal, as is now evident from observations of increases in global average air and ocean temperatures, widespread melting of snow and ice, and rising global average sea level (Haeberli \& Beneston 1998, Joughin et al. 2004, Rignot 2006, IPCC 2007). During the last 100 yrs the earth has heated up by $0.74^{\circ} \mathrm{C}$; with the linear warming trend over the last 50 yrs nearly twice as much that for the last $100 \mathrm{yrs}$.

At regional scales, numerous long-term divergent changes in climate have been observed. For instance, temperatures in Germany have increased by $0.9^{\circ} \mathrm{C}$ during the last $100 \mathrm{yrs}$, which is more than the global or European trend (Schönwiese et al. 2003). The frequency of extreme temperature events has changed: cold days, cold nights and frost have become less frequent, while hot days, hot nights, and heat waves have become more frequent. Changes in precipitation patterns are at least as divergent as in temperature patterns: rainfall increased in eastern parts of North and South America, northern Europe and parts of northern and central Asia, while drying has been observed in southern Europe, southern Africa and parts of southern Asia. Droughts are linked to higher temperatures, reduced precipitation, changes in sea surface temperatures, wind patterns, and decreased snow pack and snow cover. Meanwhile, the frequency of heavy precipitation events has increased over most land areas, consistent with warming and accompanying increases of atmospheric water vapour.

Projections for the future predict a warming of about $0.2^{\circ} \mathrm{C}$ per decade, analogous to a temperature change of $1.8^{\circ} \mathrm{C}\left(1.1-2.9^{\circ} \mathrm{C}\right.$; B1 scenario: environmental sustainability) to $4.0^{\circ} \mathrm{C}\left(2.4-6.4^{\circ} \mathrm{C}\right.$; $\mathrm{A} 1 \mathrm{FI}$ scenario: fossil intensive, very rapid growth) until the end of the century (IPCC 2007). Even if all radiative forcing agents are held constant at year 2000 levels, a further warming trend would occur in the next two decades at a rate of about $0.1^{\circ} \mathrm{C}$ per decade, mainly due to the slow response of the oceans, and would continue for centuries. Since the world's energy needs and consequently the emission of carbon dioxide will continue to grow for at least the next three decades (IEA 2005), constancy at 2000 levels is not very likely. Continued greenhouse gas emissions will cause further warming and induce many changes much larger than those observed during the $20^{\text {th }}$ century. 
Global warming will influence the global hydrological cycle. Projections indicate decreasing water availability and increasing drought risk in many regions of the world (Gerten et al. 2007), manifest as reductions in river discharge (e.g., Chalecki \& Gleick 1999), ground water resources (e.g., Sandstrom 1995), or soil moisture (Gregory et al. 1997, Wetherald \& Manabe 2002). However, rate and distribution of precipitation strongly depend on a variety of parameters, e.g., topography, vegetation structure, and land use, and therefore strongly differ in their spatial and temporal distribution. For Germany, ECHAM4 global circulation model shows a shift of the seasonal distribution of precipitation to reduced rainfall in summer and enhanced precipitation in late winter and spring (Lindner \& Cramer 2002, Kunstmann et al. 2004). Hot extremes and summer heat waves like in summer 2003 will continue to become more frequent in central and southern Europe (EEA 2004, Kundzewicz et al. 2006, Rowell \& Jones 2006). However, regional precipitation patterns in Germany can be manifold. Trömel \& Schönwiese (2007) project that an increase in precipitation in winter will be widespread in Germany, while rainfall decreases in summer will be smaller, with spatial different trends in the western and eastern part of Germany.

\section{Shift of species ranges as response to global warming}

In the past, migration has been the most common response of plants to Quaternary climate change (Huntley et al. 1991). Palynological data indicate that plant species tracked during Quaternary climate changes favourable conditions with estimated migration rates of 150-500 m year ${ }^{-1}$ (Huntley et al. 1991). Global analyses document significant range shifts of present vegetation toward the poles (or metres per decade upward) of $600 \mathrm{~m} \mathrm{year}^{-1}$ (Grabherr et al. 1994, Meshinev et al. 2000, Kullman 2001, Parmesan \& Yohe 2003, Peñuelas \& Boada 2003). These maximum rates of migration are one or two orders of magnitude too slow to track the predicted climatic changes in the next century and species may not be able to avoid the severest effects of global warming. Climate-induced ecological change is also expected to outpace the rates at which successional processes could occur in forests. The understanding of the plasticity of plant responses towards changing climatic conditions therefore becomes increasingly important. 


\section{Plant responses to elevated carbon dioxide and temperature}

The predicted rapid and simultaneous changes in several environmental factors controlling forest ecosystem function are raising concerns about future terrestrial ecosystem productivity. Among the most critical of these are the atmospheric concentrations of $\mathrm{CO}_{2}$, temperature, and precipitation (Bazzazz 1990, Mooney et al. 1991). The most direct influence mediated by anthropogenic climate change is the dramatic increase of carbon dioxide. The primary effect of elevated $\mathrm{CO}_{2}$ in most ecosystems is through a direct positive effect on photosynthetic C-fixation that increases net primary production (NPP) (Lindroth et al. 1993, Hamilton et al. 2002, Norby et al. 2002). With an increase of $\mathrm{CO}_{2}$, water use efficiency is initially improved, i.e., substantially less water is transpired per unit of carbon assimilated (Lockwood 1999, Medlyn et al. 2001a, Polley et al. 2003). However, improved water use efficiency does not necessarily lead to increased drought tolerance (Tschaplinski et al. 1995). Long-term growth in elevated $\mathrm{CO}_{2}$ concentrations has been observed to cause reduced sensitivity and acclimation of stomatal conductance to vapour pressure deficit in beech and chestnut (Heath 1998), reduced sensitivity to drought in beech (Heath \& Kerstiens 1997), and reduced sensitivity to atmospheric $\mathrm{CO}_{2}$ concentrations (Santrucek \& Sage 1996, Idso 1999). Increasing temperatures and vapour pressure deficits additionally increase the rate of evapotranspiration (Norby \& Luo 2004). Photosynthetic acclimatization to elevated $\mathrm{CO}_{2}$ and temperature reduces the water use efficiency. Thus, actual water use per individual tree may increase, if the stomatal response to $\mathrm{CO}_{2}$ and temperature is weak, particularly when $\mathrm{CO}_{2}$ enrichment causes increases in total leaf area and boosted biomass production (Eamus 1996, Betts et al. 1997, Kimball et al. 1999). Without commensurate increases in precipitation, water stress can result even at constant rainfall levels.

Secondary effects of $\mathrm{CO}_{2}$ and temperature on soil moisture via their effects on stomatal conductance and transpiration can also influence ecosystem processes (Hungate et al. 1997, Yang et al. 2003). As forest evapotranspiration is increased, soil moisture is likely to decrease, which might have consequences for run-off, production, soil mineralisation, and regional climate change (Fig. 1; Zak et al. 1993, Field et al. 1995, Kirschbaum 1995, Sellers et al. 1996, Thornley \& Cannell 1996, Kellomäki \& Vaisanen 1997, Rustad et al. 2001, Hayhoe et al. 2007). Besides, interactive effects might be expected to occur such that warming alters the relationship between $\mathrm{CO}_{2}$ and NPP, or $\mathrm{CO}_{2}$ alters the effect of temperature on species composition. 


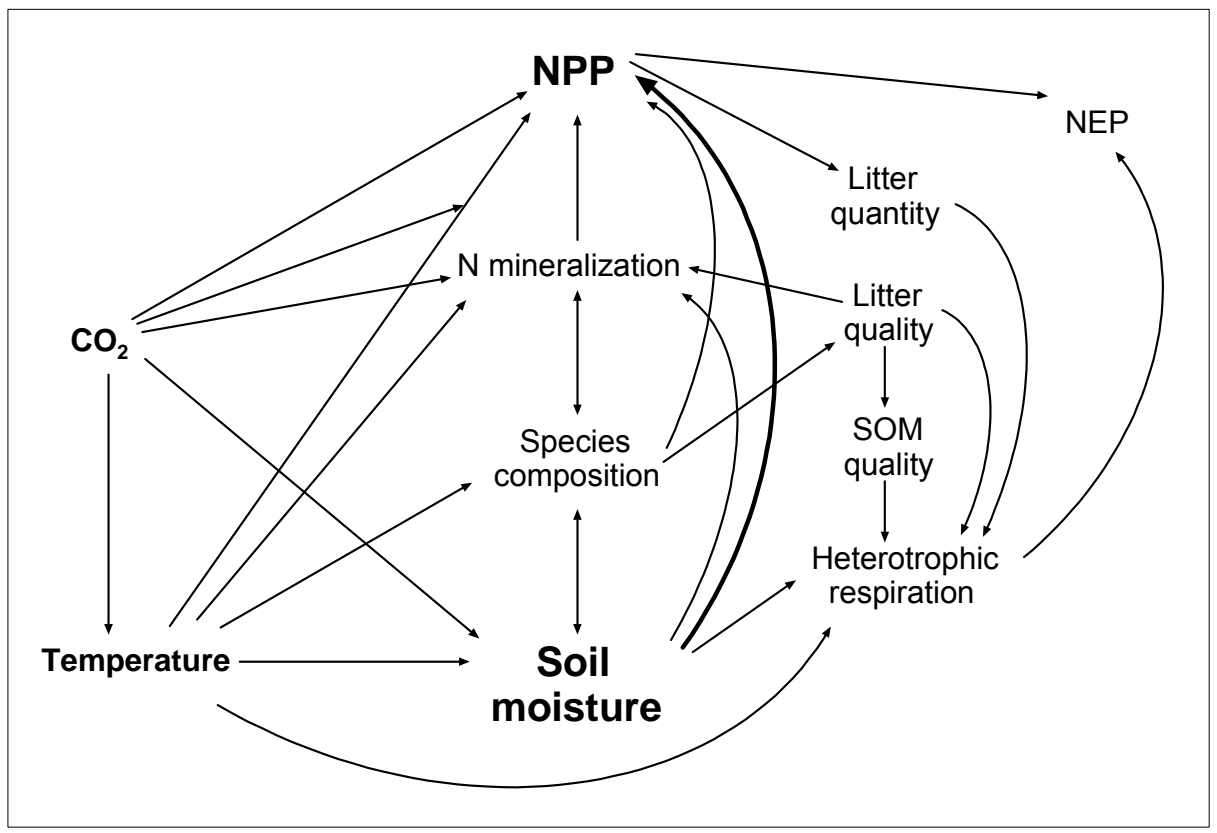

Figure 1. A simplified causal loop diagram for illustrating the interactions between atmospheric $\mathrm{CO}_{2}$ concentrations and temperature on ecosystem processes (according to Norby \& Luo 2004, modified). NEP $=$ Net ecosystem production, NPP $=$ Net primary production, $\mathrm{SOM}=$ Soil organic matter.

Both elevated $\mathrm{CO}_{2}$ and temperature could contribute to a reduction of soil moisture conditions: despite an initial increase of water use efficiency, elevated $\mathrm{CO}_{2}$ will in the long-term lead to increased water use due to photosynthetic acclimatization to elevated $\mathrm{CO}_{2}$ and thus a decrease of water use efficiency, which is even combined with boosted biomass production. Rising temperature will increase the water use of plants by elevated vapour pressure deficit and, thus, evapotranspiration. The affect of both increased $\mathrm{CO}_{2}$ and temperature on soil moisture will further impair the water supply for plants that will be already diminished due to lower precipitation amounts in summer. Water deficiencies might become more hazarding for ecosystems than altered $\mathrm{CO}_{2}$ or temperature regimes. Therefore, a deeper understanding of the response of plants to soil moisture deficits is required.

\section{Increasing water stress during the growing season}

In many regions of the world, net primary production is in the first instance limited by available soil water and only secondly by temperature, $\mathrm{CO}_{2}$, or radiation (Nemani et al. 2002, Xiao \& Moody 2004). The geobiosphere as a whole appears to be currently in a state of water deficiency (Lee \& Veizer 2003). Therefore, future precipitation decreases in summer will likely have great impacts on ecosystem processes. Although precipitation patterns are spatially and temporally highly variable and predictions have 
a higher uncertainty factor than those for $\mathrm{CO}_{2}$ and temperature, models rather tend to predict a decrease of precipitation during the growing season in central and eastern Germany. Precipitation is often used as a proxy of soil water availability; therefore declining precipitation can be linked to a decrease in soil moisture. If soil water content falls below some species-specific level, plants experience drought stress that alters both soil-root and leaf-atmosphere interfaces and threatens the integrity of the liquid phase continuum from soil to leaves (Bréda et al. 2006). Consequently, transpiration rate and carbon assimilation are disordered at low soil moisture. The amount of stored carbohydrates is reduced and the storage compartments cannot fully be refilled at the end of the growing season. Any additional demand on already limited reserves may delay or inhibit recovery of the growth potential (Deans 1979, Kuhns et al. 1985). As a consequence, both height and radial growth, as well as bud production and leaf area are frequently smaller during several years following a severe drought (Becker 1989, Battaglia 1998, Le Dantec 2000, Bréda et al. 2006). Stem diameter growth of trees has often been observed to be even more sensitive to soil water shortage than photosynthesis (Dreyer 1997). Moreover, drought-induced physiological disorders increase tree vulnerability to secondary stresses like insect damage (Tuomi et al. 1988, Docherty et al. 1997, Rouault et al. 2006), pathogens (Dale et al. 2001, DesprezLoustau et al. 2006), frost or another drought. Additionally, nitrogen nutrition is likely to be modified by drought (Fotelli et al. 2004, Geßler et al. 2004). Such cumulated processes may lead to long-term responses sometimes over several years and may end either with complete or partial recovery of tree growth, or with a final shift into decline and eventual death (Law et al. 2002). Tree decline is related to a hydraulic dysfunction (Pockman \& Sperry 2000) or to a deficit in carbon balance, while mortality may be related to local variability in soil properties or to genetic diversity among and within tree species (Bréda et al. 2006). Indeed, such mortality can be regarded as the expression of a selection process against sensitivity to drought.

\section{Possible consequences of anthropogenic climate change for European} beech forests

In Central Europe, European beech (Fagus sylvatica L.) is the economically most important deciduous tree species (Table 1). F. sylvatica is a late-successional tree species with a wide natural distribution range that spreads from southern Sweden to central Italy and from France and northern Portugal to central Greece (Fig. 2). The high shadow tolerance as seedling and sapling, and the ability to cast deep shade as mature tree makes European beech a strong competitor. F. sylvatica is therefore able 
to displace other tree species and to get to dominance on sites representing a relatively broad spectrum of nutrient and hydrological regimes, from highly acidic to basic soils (Leuschner et al. 2006a) and from low to high rainfall conditions.

Table 1. Current surface ratio of tree species in Germany (Bundeswaldinventur 2001-2002).

\begin{tabular}{lrrllr}
\hline Deciduous trees & {$[\%]$} & & Coniferous trees & [\%] \\
\cline { 1 - 2 } \cline { 5 - 6 } European beech & 14.8 & & Norway spruce & 28.2 \\
Oak & 9.6 & & Pine & 23.3 \\
All deciduous & 40.1 & & All coniferous & 57.6 \\
\hline
\end{tabular}

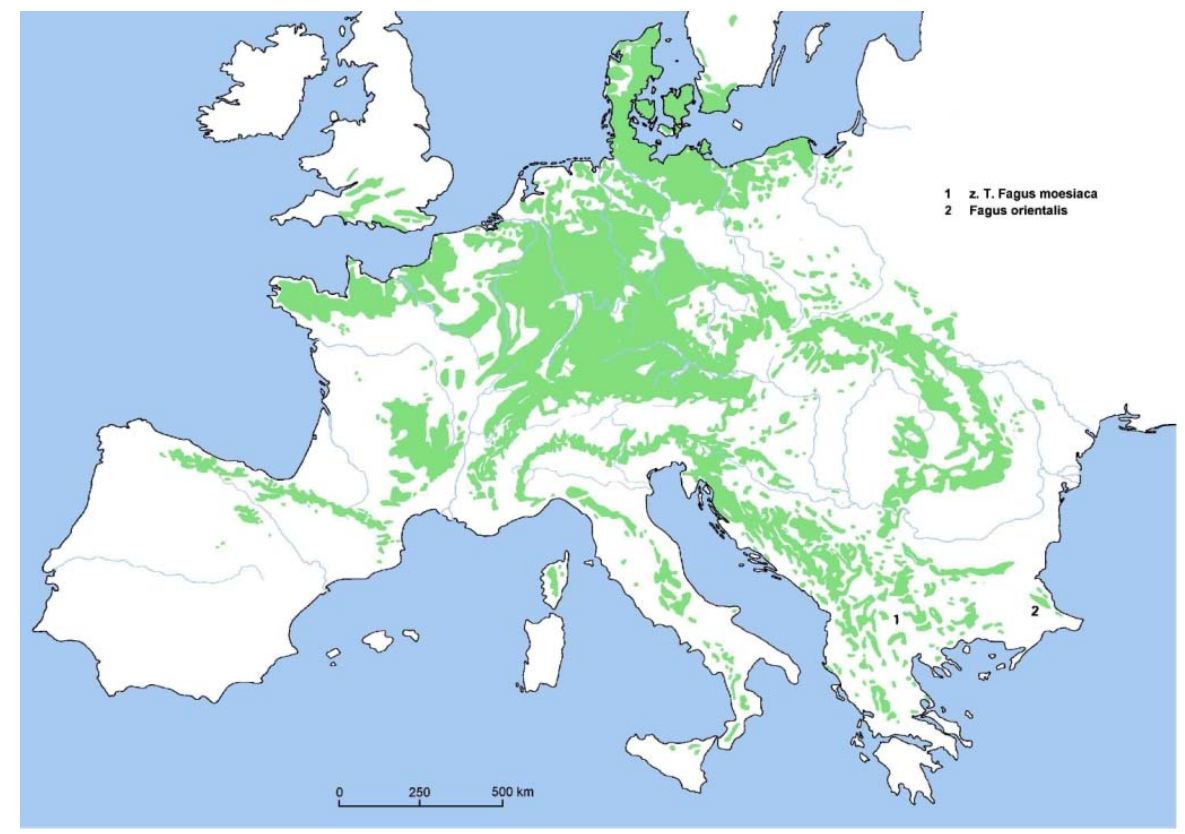

Figure 2. Natural distribution of beech forests in Europe (according to Bohn 1992, modified by Hertel).

In some observations, elevated $\mathrm{CO}_{2}$ concentrations were found to increase the wateruse efficiency in beech saplings and forest stands, thereby stimulating photosynthetic carbon gain and growth (Medlyn et al. 2001b, Bergh et al. 2003). However, Cech et al. (2003) found in mature stands of $\mathrm{F}$. sylvatica a negligible $\mathrm{CO}_{2}$ effect on stand transpiration and water use efficiency. The growth response to $\mathrm{CO}_{2}$ changes with time: in long-term $\mathrm{CO}_{2}$ enrichment experiments (FACE-experiments) with beech saplings and mature forest stands, growth was initially stimulated, but varied largely between years and was not persistently increased (Spinnler \& Körner 2002, Körner et al. 2005). Körner (2003) concluded that growth is not limited by carbon supply, but rather controlled by sink activity and by a direct control by other environmental or developmental constraints. Therefore, growth and competitive ability of European 
beech will not necessarily respond to increasing $\mathrm{CO}_{2}$ concentrations, but may be stronger influenced by intensive droughts that occur during the growing season (Geßler et al. 2007).

Even though $F$. sylvatica grows on sites representing a relatively broad spectrum of hydrological regimes, this tree species has been found to operate its transpiration close to the cavitation induction point (Bréda et al. 2006). Hence, beech is more sensitive to drought-induced xylem embolism and to stem growth reductions upon water shortage than other temperate broad-leaved tree species such as oaks (Bréda et al. 1993, Epron et al. 1995, Magnani \& Borghetti 1995, Backes \& Leuschner 2000, Cochard et al. 2001, Leuschner et al. 2001a). Drought-sensitive beech regulates water loss conservatively (Backes \& Leuschner 2000). In only moderately dry summers, a sensitive stomatal regulation prevents dramatic reductions in turgor, leaf water potential, and photosynthesis. During irregular severe droughts stomatal responses do not appear to adequately prevent loss of hydraulic conductivity (Geßler et al. 2001). Marked decreases in predawn leaf water potential (Tognetti et al. 1995, Backes \& Leuschner 2000), canopy conductance (Granier et al. 2000, Geßler et al. 2004, Schipka et al. 2005), photosynthetic capacity (Terborg 1998, Bergh et al. 2003), stem diameter growth (Brockmann et al. 1987, Becker et al. 1994, Lebourgeois et al. 2005, Schipka et al. 2005), height growth (Braun \& Flückiger 1987, Frech 2006), and NPP (Ciais et al. 2005) cannot be avoided. Dry-hot weather conditions during summer can also lead to a direct reduction of canopy leaf area index of beech due to premature leaf shedding or to canopy dieback on shallow soils in the course of severe droughts (Stefancik 1997, Bréda et al. 2006, Kohler et al. 2006).

In general, plants tend to produce smaller, more xeromorphic leaves and a reduced total leaf area when exposed to drought. For mature trees or forests of European beech, however, the leaf area-water supply relationship is not well understood yet. The existing gradient studies in forests focussing on the leaf area-water supply relationship referred to long gradients and typically included a tree species turnover between the moist and dry ends of the gradient (e.g., Grier \& Running 1977, Hinckley et al. 1981, Runyon et al. 1994, Turner 1994, Jose \& Gillespie 1997, Cunningham et al. 1999, Reich et al. 1999, Wright et al. 2004). This kind of data may allow general conclusions on how water shortage affects forest leaf area within biomes, but it gives no insight into a tree species' adaptive potential with respect to leaf area development and leaf morphology. Yet, the leaf area-water supply relationship may serve as a valuable indicator of tree vitality, when the water regime changes (Thuiller et al. 2004).

However, while some attention has been paid to the drought response of aboveground organs such as stems, twigs and leaves, only very little is known about the response of 
the root system of mature beech trees to water shortage. Fine roots, i.e., roots $<2 \mathrm{~mm}$ in diameter, represent a small but functionally highly important fraction of tree biomass, which might respond more sensitively to drought than aboveground organs. Although fine roots constitute only about $2-3 \%$ of the total biomass, fine root production may account for roughly $50 \%$ of the carbon cycled in forests, and can consume up to $66 \%$ of the annual photosynthate assimilated by the canopy (Nadelhoffer \& Raich 1992, Hendrick \& Pregitzer 1993, Vogt et al. 1996). Any distortion of the fine root system by stressors such as drought should therefore not only influence tree vitality, but might also affect carbon and nutrient cycling in the ecosystem.

According to the optimal partitioning theory, plants should allocate relatively more carbon and nutrients should be allocated to root growth than to aboveground growth, when plant growth is limited by water and/or nutrient shortage (Bloom et al. 1985). However, evidence in support of this theory, when applied to tree root growth during water shortage, is partly contradictory and should be scale-dependent. The few studies that examined the root systems of a single tree species along precipitation gradients showed decreases in fine root biomass with decreasing rainfall (Nisbet \& Mullins 1985, Leuschner \& Hertel 2003, Leuschner et al. 2004). Increasing water shortage was found to inhibit fine root production in temperate forests (e.g., Teskey \& Hinckley 1981, Kuhns et al. 1985, Burton et al. 2000, Joslin et al. 2001). However, stimulation of tree fine root growth by drought has also been reported (e.g., Santantonio \& Hermann 1985, Leuschner et al. 2001a). Unfortunately, most data sets refer to one or two stands only. This makes conclusions on the more general relationship between tree root system size or activity and water availability difficult.

European beech will have to respond to rapidly changing climatic conditions or will face local extinction if not sufficiently adapted to altered drought and temperature conditions. Adaptability to a changing environment can be achieved by different means: a population can exhibit a high degree of genetic variability, comprising genotypes adapted to different environments, or a given genotype can exhibit a certain degree of phenotypic plasticity, coding for the ability of the individual to express different physiological or morphological phenotypes in different environments (Gregorius \& Kleinschmit 1999, Pigliucci 2001, Callaway et al. 2003). Rapid climate change as predicted requires a better understanding of the genetic and phenotypic basis of the adaptation of beech leaves and fine roots to altered drought regimes. 


\section{Objective and approach}

Since global warming and the resulting weather extremes, e.g., increased summer droughts, are predicted to proceed at an accelerated rate (Rowell \& Jones 2006, IPCC 2007), a deeper insight into the ability of important late-successional tree species to respond to these rapidly changing climatic conditions is required. This response will need a broad ecological adaptability, which can be achieved by either a high degree of genetic variability of a population or a high degree of phenotypic plasticity in physiology and morphology exhibited by a given genotype.

In this study, the drought response of drought-sensitive European beech (Fagus sylvatica L.) was studied on the two key interfaces for water flow in the soil-plantatmosphere continuum (SPAC): fine roots and leaves.

Major aims of this study were to

(i) investigate long-term adaptive responses of adult beech trees to low soil moisture,

(ii) test the optimal resource partitioning theory, which predicts enhanced root growth during drought in order to reduce water limitation in desiccated soil, and

(iii) differentiate between the specific contribution of phenotypic plasticity and genetic variability to the drought response of Fagus sylvatica in a common garden experiment.

The drought response of beech was investigated in a combination of field studies and experiments:

- in a transect study with 14 mature forest stands on uniform geological substrate, but with a large decrease in annual precipitation (970 to $520 \mathrm{~mm} \mathrm{yr}^{-1}$ ) (Chapter III and IV) and

- in a common garden experiment with four beech populations from regions with low to high precipitation, grown at ample (10 vol.\%) or reduced soil moisture (5 vol.\%) in the outdoor Göttingen Rhizolab Facility (Chapter V). 
Chapter 2

Materials and methods 


\section{Methodically approach}

In this study, the drought response of European beech was studied simultaneously at several levels. Studies were conducted with both beech saplings and mature forests stands. A precipitation transect study (field study) investigated the in situ reaction of adult trees; while in an experimental investigation in the defined conditions of the outdoor Göttingen Rhizolab Facility, interacting covariates could be completely excluded from the drought response of beech saplings.

\subsection{Transect study}

\section{Study sites}

Fourteen mature beech forests with comparable stand structure were selected for study in the centre of the distribution range of Fagus sylvatica in central Germany (Fig. 1). The sites were chosen along a $150 \mathrm{~km}$ long WNW-ESE transect in level to slightly sloping terrain at elevations of 230 to $440 \mathrm{~m}$ a.s.l. All stands grew on the same geological substrate (Triassic sandstone of Middle Bunter) to ensure sufficient comparability of soil chemical conditions. Stand selection criteria were (i) closed canopy without major gaps, (ii) even-aged stand structure (100 to $140 \mathrm{yrs}$ old; extremes: 90 and 157 yrs), (iii) no significant presence of other tree species, and (iv) similar stem densities $\left(175-250 \mathrm{ha}^{-1}\right)$.

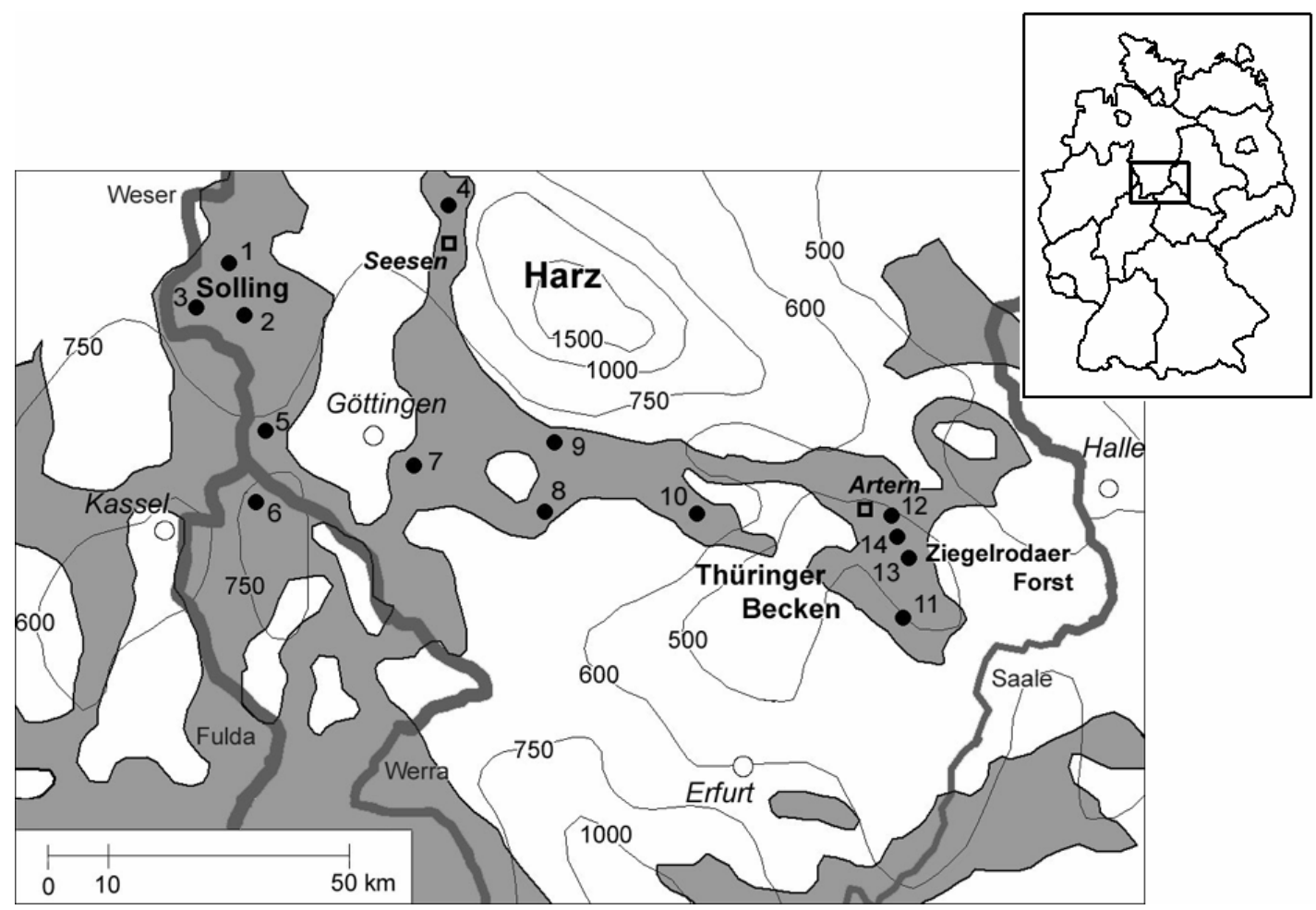

Figure 1. Survey map of the distribution of annual precipitation (isohyets in $\mathrm{mm}$ ) and of the geological substrate Middle Bunter (grey) in central Germany. Dots designate the location of the 14 study sites (Map basis: Kartographische Anstalt Georg Westermann 1985, modified). 
Seesen

[mm]

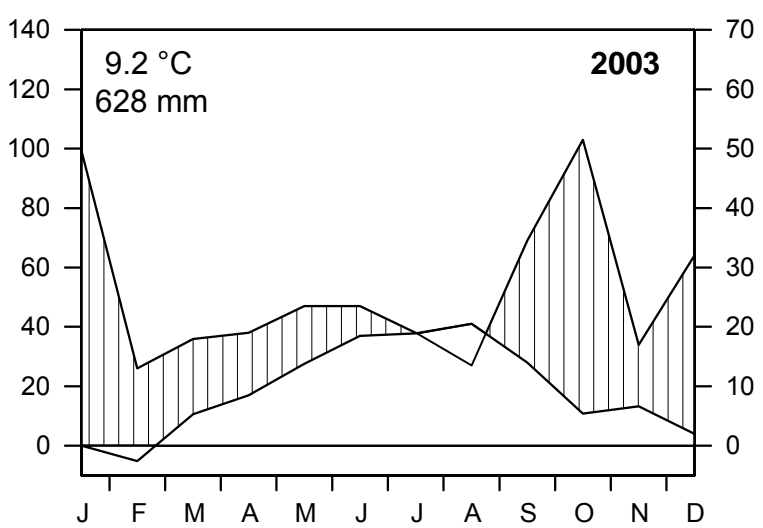

[mm]

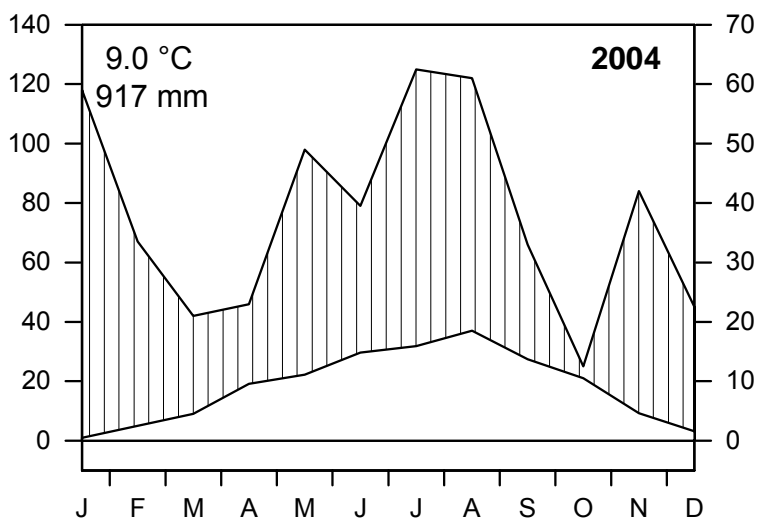

$\left[{ }^{\circ} \mathrm{C}\right][\mathrm{mm}]$
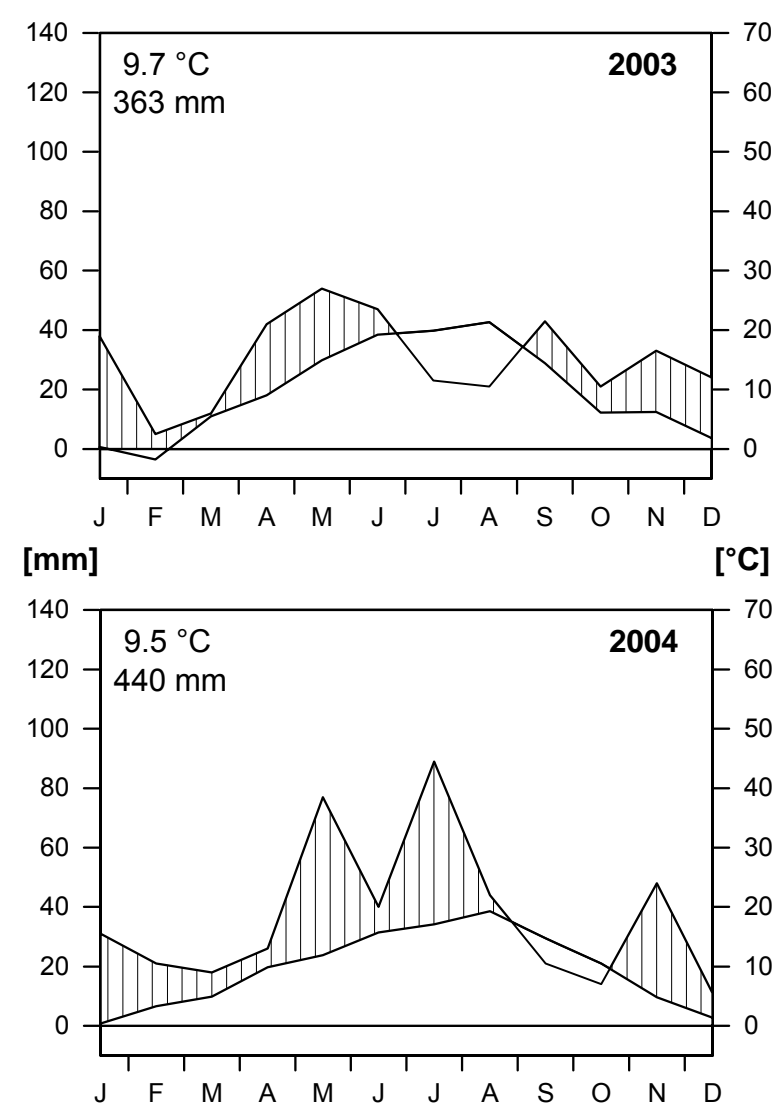

[mm]

$\left[{ }^{\circ} \mathrm{C}\right][\mathrm{mm}]$

$\left[{ }^{\circ} \mathrm{C}\right]$
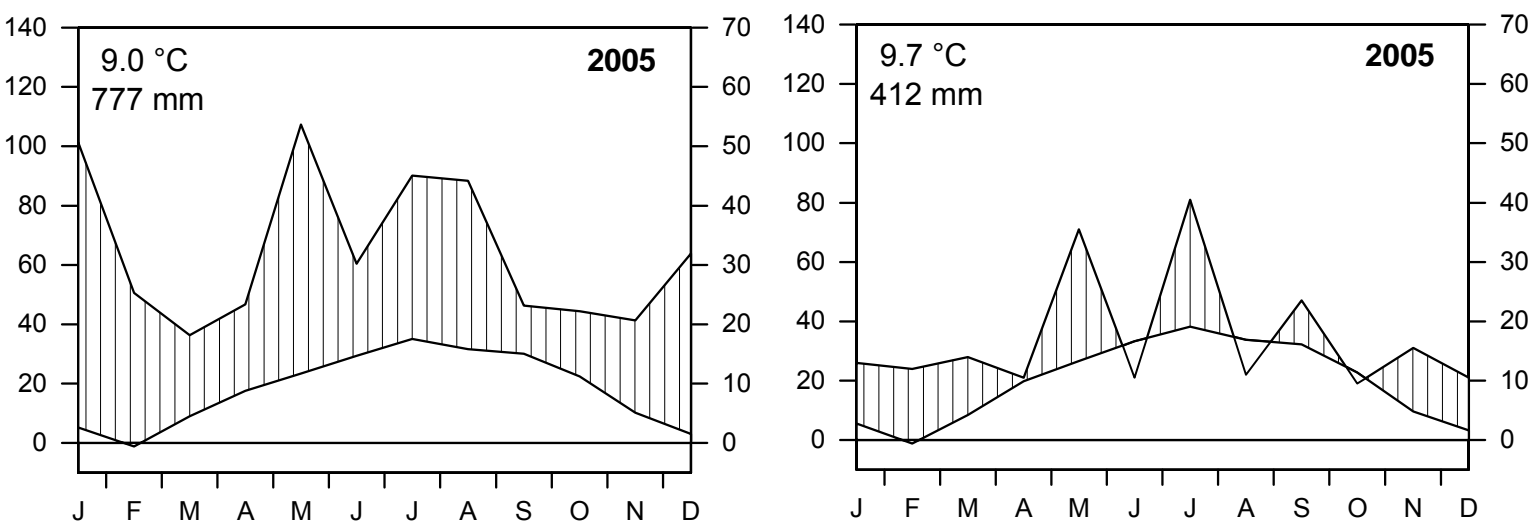

Figure 2. Climate diagrams of climate stations located on the moist (Seesen) and on the dry end (Artern) of the investigated precipitation gradient in Germany. Values given are data for the dry year 2003, the wet year 2004 , and the moderately dry year 2005 . Long-term means: Seesen $8.5^{\circ} \mathrm{C}, 859 \mathrm{~mm} \mathrm{yr}^{-1}$; Artern $8.6^{\circ} \mathrm{C}, 475 \mathrm{~mm} \mathrm{yr}^{-1}$.

The stands were founded either from seeds or from planting of seedlings of autochthonous (local) origin. Typically, beech formed a single closed canopy (monolayer) with a second tree layer and shrubs being mostly absent. Forest management activities in the stands had not been conducted for at least seven yrs, in most cases for more than ten yrs prior to the study. Mean tree height in the upper canopy layer was $34 \mathrm{~m}$ in the 14 stands (extremes: $30-38 \mathrm{~m}$ ) and mean breast height diameter was 
$41 \mathrm{~cm}(32-51 \mathrm{~cm})$. The sites were not affected by compensatory liming activities of forestry except for stand \#6 (8 yrs ago) and \#3 (13 yrs ago).

Mean annual temperature was $7.8^{\circ} \mathrm{C}$ with a tendency for slightly higher temperatures in the eastern, more continental section of the gradient. Mean annual precipitation

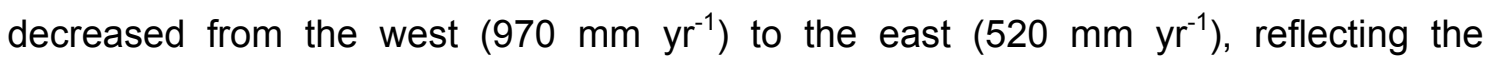
transition from a more sub-oceanic to a more sub-continental climate in the rain shadow of the Solling and Harz mountains. The corresponding summer rainfall (May to September) decreased from 420 to $270 \mathrm{~mm} \mathrm{yr}^{-1}$. The investigation took place from 2003 to 2005, in three years with highly contrasting precipitation and temperature regimes (Fig. 2). The summer 2003 was the hottest summer in the region since 1901, with about $20 \%$ less annual precipitation than the long-term mean in the study area. In contrast, the summer 2004 was wetter than the average record for the study area, while in the summer 2005 , the precipitation regime was closer to the average.

\section{Determination of biomass allocation patterns and morphology}

Stand leaf mass or annual leaf production and leaf area index (LAI) were recorded by litter trapping in 2003 and 2004 in all 14 stands. Leaf area was analysed with the computer program Win FOLIA (Régent Instruments, Quebec, Canada). Leaves of the upper sun canopy were harvested in July/August 2005 and 2006 with a crossbow. Next to leaf area analyses these leaves were also used for determination of $\delta^{13} \mathrm{C}$ in the dry mass (details in Chapter III).

In the years 2003 to 2005, profile totals of fine root biomass and necromass of beech were investigated by soil coring. For detecting the mostly detritus-like fine root necromass, every third root sample of the 2005 campaign was subjected to an in-depth analysis for even smallest root fragments, adopting a method introduced by Van Praag et al. (1987) and modified by Hertel \& Leuschner (2002). Specific fine root surface area (SRA) was determined with the computer program WinRHIZO (Régent Instruments, Quebec, Canada). The cumulative fine root surface area index (RAI) was obtained by multiplying fine root biomass with SRA. Fine root biomass samples were extracted in July 2005 for analysing the $\delta^{13} \mathrm{C}$-signature in the dry matter by mass spectroscopy (Delta plus, ThermoFinnigan, USA). The ingrowth core method was applied for assessing the growth potential of the fine roots in the 14 stands. By relating root increment per year to the standing stock of fine root biomass in the direct proximity of the cores, relative fine root ingrowth rate as a rough estimate of fine root turnover could be calculated (details in Chapter IV). 


\subsubsection{Soil nutrient status of European beech stands across the precipitation transect}

In the transect study of 14 beech forests with a large reduction of annual precipitation (970-520 mm $\mathrm{yr}^{-1}$ ), sites on the same geological substrate (Triassic sandstone of Middle Bunter, formation 'Hardegsen Folge') were chosen to ensure sufficient comparability of soil chemical conditions. Among the five 'ecosystem state factors' defined by Jenny (1941) - climate, relief, organisms, parent material and time - four were regarded to be approximately constant in this investigation. Variation in parent material and relief could be reduced to a minimum by selecting suitable beech stands on the Triassic sandstone Middle Bunter, with absent or insignificant cover layers of quaternary loess and in similar topographic positions within a limited area. The time factor had a similar influence at all studied forest sites, because all soils have developed since the Holocene since about 12,000 yrs, and all beech stands were of similar age. A major strength of this study is that single-species stands of the same tree species were compared, which largely eliminates the organism factor that might have a profound influence on the properties of forest floor and mineral topsoil.

Yet, variable precipitation amounts can also have an effect on soil chemical properties and nutrient status of forest soils under a temperate suboceanic climate by faster rock weathering, greater leaching of soil elements, and increased atmospheric deposition (Stark 1994, Newman 1995, Quilchano et al. 1995, Raich et al. 2000). In order to analyse the effect of annual rainfall on soil development and nutrient status of beech forests of the transect study, the aims were (i) to define the range of important soil chemical and nutrient parameters among the 14 Central European beech forests grown on Triassic sandstone, and (ii) to investigate the dependence of the nutrient status of the beech forests on the precipitation amount.

\section{Soil sampling and chemical analyses}

A soil profile examination was carried out at every study site in a soil pit in the centre of the plot following the criteria of 'Arbeitskreis Standortskartierung' (1996). Humus forms were classified according to Green et al. (1993), soil types after IUSS-ISRIC-FAO (2006). Soil samples were taken in April 2004 at five randomly chosen locations within the $20 \times 20 \mathrm{~m}$ study plot in both the organic layer and the mineral soil (0-10 and 10-20 cm depth). To account for spatial variability, each of the five samples consisted of four sub-samples that were taken at random locations within a $50 \mathrm{~cm}$ radius around the respective sampling point. These sub-samples were mixed and used for single analysis. Sample preparation and chemical analyses mainly followed the protocol given 
by 'Bundesweite Bodenzustandserhebung im Wald' (BMELF 1994). Additionally, plantavailable phosphorus according to Bowman \& Cole (1978) was extracted by resin bags that were placed for $16 \mathrm{~h}$ in a solution of $1 \mathrm{~g}$ soil material suspended in $30 \mathrm{ml}$ water (Sibbesen 1977). The phosphorus was re-exchanged by $\mathrm{NaCl}$ and $\mathrm{NaOH}$ solutions and analysed by blue-dyeing (Murphy \& Riley 1962) and photometric measurement. For the characterization of the $\mathrm{N}$-supply, leaves of the upper sun canopy were sampled with a crossbow in 2006 in ten of the 14 stands ( $n=8$ per stand) and analysed for $\delta^{15} \mathrm{~N}$ by mass spectroscopy (Delta plus, ThermoFinnigan, USA) at the Centre for Stable Isotope Research and Analysis (KOSI) of the University of Göttingen.

\section{Statistical analyses}

Means and standard errors of the soil chemical data were calculated from each five samples per study site. Statistical analyses were conducted with the package SAS, version 8.2 (Statistical Analyses System, SAS Institute Inc., Cary, NC, USA). Probability of fit to normal distribution was tested by a Shapiro-Wilk test. In the case of Gaussian distribution, mean values of the study sites were compared by a one-factorial analysis of variance followed by a Scheffé test. We employed linear regression analysis to quantify the influence of precipitation, temperature and various soil chemical factors on each other. Significance was determined at $p<0.05$ in all tests.

Soil types, humus profiles, and soil chemistry of beech forests on Triassic sandstone

The 14 investigated Central European beech forests on Middle Bunter grew on soil types ranging from podzolic Umbrisols in the moister stands to acidified Cambisols in the drier stands (Table 1). Humus forms were varying from leptomoders to thin vermimulls, with a tendency for thicker organic layers at high soil moisture conditions.

Soil acidity of the mineral soil ranged from $\mathrm{pH}(\mathrm{KCl}) 2.7$ to 5.0 and significantly increased from stands with less than $600 \mathrm{~mm} \mathrm{yr}^{-1}$ (mean $\mathrm{pH} 3.6$ ) to stands with more than $900 \mathrm{~mm} \mathrm{yr}^{-1}$ (mean pH 3.0; Fig. 3a). Correspondingly, the buffer range changed from the cation exchange to the Al buffer range at the moister end of the transect. In the Al buffer range exchangeable cations are lost and increasingly more silicatic aluminium is dissolved in the soil solution. Elevated Al contents in the soil solution may negatively influence the activity of decomposers and have toxic effects on fine roots (Barceló \& Poschenrieder 2002) in the forests stands with high annual precipitation amount. 
Table 1. Topographic, edaphic, and climatic parameters of 14 beech stands on Triassic sandstone along a precipitation gradient in central Germany. Mean annual precipitation and temperature were derived from weather station data that was corrected for altitude.

\begin{tabular}{|c|c|c|c|c|c|c|c|}
\hline $\begin{array}{c}\text { Site } \\
\#\end{array}$ & $\begin{array}{l}\text { Altitude } \\
\text { [m a.s.l.] }\end{array}$ & Exposition & $\begin{array}{c}\text { Inclination } \\
{\left[{ }^{\circ}\right]}\end{array}$ & $\begin{array}{c}\text { Humus } \\
\text { form }\end{array}$ & Soil type & $\begin{array}{c}\text { Precipitation } \\
{\left[\mathrm{mm} \mathrm{yr}^{-1}\right]}\end{array}$ & $\begin{array}{c}\text { Temperature } \\
{\left[{ }^{\circ} \mathrm{C}\right]}\end{array}$ \\
\hline 1 & 400 & NW & 9.1 & Im & $\mathrm{pU}$ & 970 & 7.3 \\
\hline 2 & 380 & NW & 4.0 & Im & U-L (p) & 950 & 7.4 \\
\hline 3 & 340 & NW & 4.3 & Im & $U(p)$ & 910 & 7.7 \\
\hline 4 & 250 & SW & 7.4 & Im & L-U (p) & 860 & 8.2 \\
\hline 5 & 410 & $\mathrm{NE}$ & 1.6 & $\mathrm{~m}$ & L-C & 820 & 7.3 \\
\hline 6 & 440 & NW & 6.7 & $\mathrm{vm}$ & L & 800 & 7.1 \\
\hline 7 & 250 & $\mathrm{~N}$ & 1.2 & $\mathrm{~m}$ & C & 680 & 8.2 \\
\hline 8 & 340 & SW & 9.5 & $\mathrm{~m}$ & C & 670 & 7.7 \\
\hline 9 & 320 & $S$ & 4.3 & $\mathrm{vm}$ & L-C & 650 & 7.8 \\
\hline 10 & 320 & NW & 4.8 & $\mathrm{vm}$ & L-C & 580 & 7.8 \\
\hline 11 & 280 & NW & 2.3 & $\mathrm{~m}$ & C & 580 & 8.0 \\
\hline 12 & 230 & SW & 5.2 & Im & C-eL & 550 & 8.3 \\
\hline 13 & 240 & SE & 3.0 & $\mathrm{~m}$ & C-L & 550 & 8.3 \\
\hline 14 & 280 & NW & 1.3 & $\mathrm{~m}$ & C & 520 & 8.0 \\
\hline
\end{tabular}

Humus form (cf. Green et al. 1993): Im = leptomoder; $m=$ mullmoder; vm = vermimull.

Soil type (WRB): $C=$ Cambisol, $e=$ eutric, $L=$ Leptosol, $p=$ podzolic, $U=$ Umbrisol

The observed increase in acidity with increasing precipitation was paralleled by a tendentious decrease of base saturation in the mineral soil from stands with low to high annual precipitation amount (mean 51 to $36 \%$; Fig. 3b). The variation of base saturation was comparably high, though, and the correlation to annual rainfall not significant. Soft beech foliage has been found to be highly susceptible to leaching processes, which are a very important pathway in the nutrient cycle of the basic cations calcium, magnesium and potassium (Rothe et al. 2002). However, $\mathrm{Ca}, \mathrm{Mg}$ and $\mathrm{K}$ inputs to soils has been observed to be less than outputs, indicating net leaching from the mineral soil (Ukonmaanaho \& Starr 2002). Increasing summer deficit in the water balance reduces this leaching loss of base cations (Yavitt \& Wright 1996). Thus, lower annual precipitation at the drier end of the transect of this study caused lower leaching rates from the soil and relative enrichment of soil base cations in the long-term, whereas higher annual precipitation amounts caused a relative depletion. The enhanced leaching of base cations from the soil in the moist stands induced nutrient deficiencies, as indicated by a higher, viz more unfavourable C/K (548 vs. $267 \mathrm{~mol} \mathrm{~mol}^{-1}$; Appendix: Table A1) and C/Mg (833 vs. 463) ratios in the organic layer in stands with high annual rainfall. 

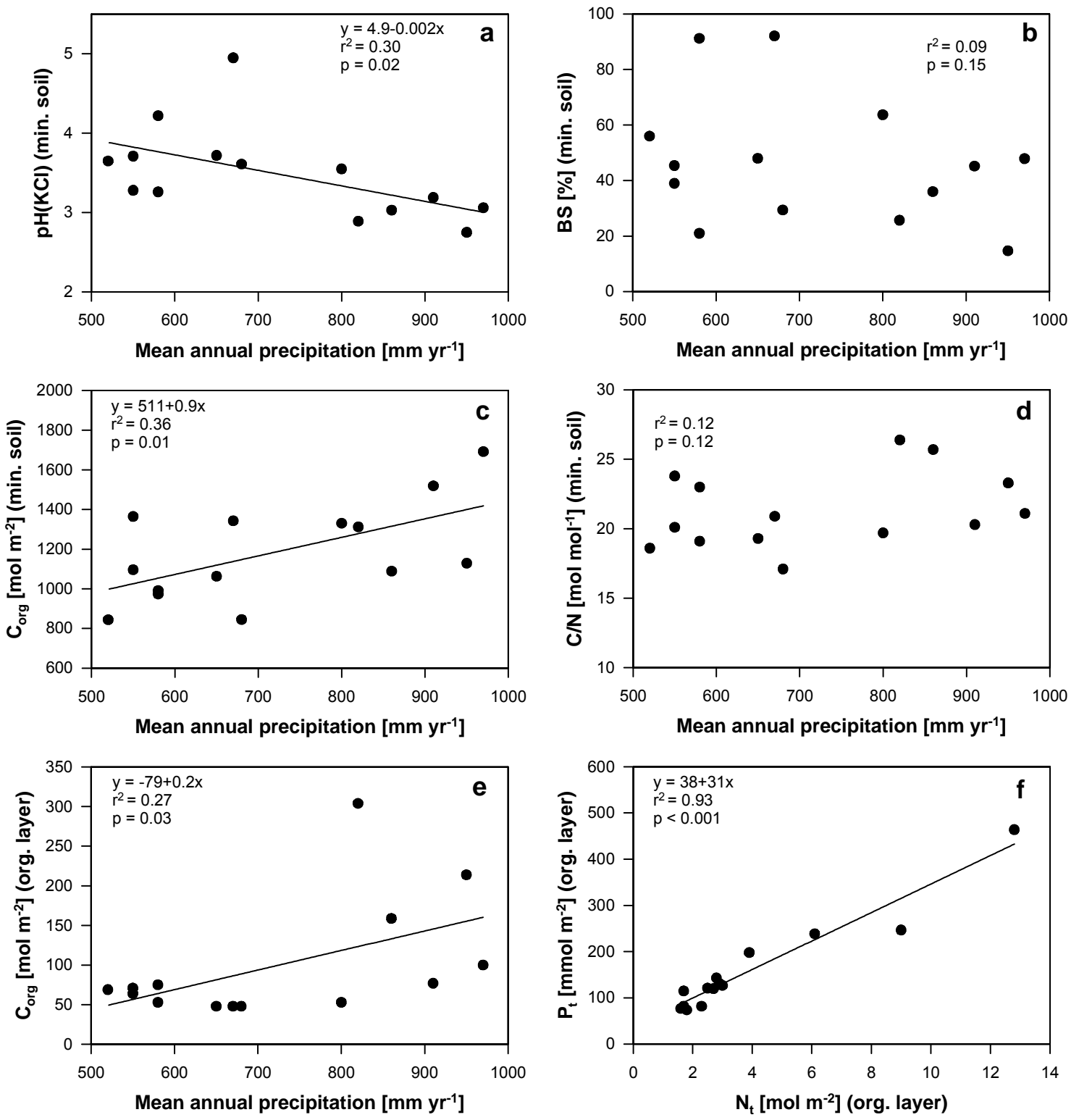

Figure 3. Some relationships of mineral soil properties $(0-20 \mathrm{~cm})$ with annual precipitation (a-d), of organic layer properties with annual precipitation (e), and of organic layer properties (f) in beech forests on Triassic sandstone (Middle Bunter) along a precipitation gradient in central Germany (mean of five soil samples per study site). Values given are the relationship of $\mathrm{pH}(\mathrm{KCl})$, base saturation (BS), organic carbon pool, and $\mathrm{C} / \mathrm{N}$ ratio in the mineral soil and of the organic carbon pool in the organic layer to the annual precipitation amount, as well as of the P-pool to the $\mathrm{N}$-pool in the organic layer.

The organic carbon pool in the mineral soil of beech forests significantly increased from $1050 \mathrm{~mol} \mathrm{C}_{\text {org }} \mathrm{m}^{-2} 20 \mathrm{~cm}^{-1}$ in stands with less than $600 \mathrm{~mm} \mathrm{yr}^{-1}$ to $1450 \mathrm{~mol} \mathrm{C}_{\text {org }} \mathrm{m}^{-2}$ in stands with more than $900 \mathrm{~mm} \mathrm{yr}^{-1}$ (Fig. 3c). A similar increase of soil organic carbon with increasing annual rainfall was found by Quilchano et al. (1995). Our regression analyses showed that the carbon pool in the mineral soil was correlated to precipitation and temperature only, but not to any of the other chemical properties investigated in the organic layer or mineral soil (Appendix: Table A3). This might give a hint on a stronger dependence of the organic carbon pool on climatic influences on the biosphere and an independence of the accordant influences on the pedosphere. 


\section{Depth and quality of organic layer on Triassic sandstone}

Soils on Triassic sandstones contained $1.7-7.6 \mathrm{~kg} \mathrm{~m}^{-2}$ of organic matter or 48$304 \mathrm{~mol} \mathrm{C} \mathrm{m}^{-2}$ on top of the soil surface (Fig. 3e). We found the largest amounts in stands with $>900 \mathrm{~mm} \mathrm{yr}^{-1}$ (mean $4.0 \mathrm{~kg} \mathrm{~m}^{-2}$ or $130 \mathrm{~mol} \mathrm{C} \mathrm{m}^{-2}$ ), while organic matter was more similar in stands with $\leq 800 \mathrm{~mm} \mathrm{yr}^{-1}$ (mean $3.0 \mathrm{~kg} \mathrm{~m}^{-2}$ or $59 \mathrm{~mol} \mathrm{C} \mathrm{m}$ ). This decrease in organic layer dry mass was closely linked to the soil type sequence from more podzolic to more eutric soils in the drier stands and to the sequence of humus profiles from leptomoders to mullmoders. According to our regression analyses the accumulation of $\mathrm{C}$ in the organic layer was also closely related to that of nitrogen as evidenced by a determination coefficient of 0.997 for the C-pool/N-pool relation (Appendix: Table A2). Next to the strong dependence on the amount of nitrogen, the Camount in the organic layer was also closely related to the amount of phosphorus $\left(r^{2}=0.94\right.$; Appendix: Table A2), as were the amount of nitrogen and phosphorus to each other $\left(r^{2}=0.93\right.$; Fig. $\left.3 f\right)$.

Nutrient partitioning between organic layer and mineral soil as dependent on annual rainfall

Principal soil chemical parameters potentially limiting for plant growth are the macroelements $\mathrm{N}$ and $\mathrm{P}$. With a general decrease of the base content, the total pool of nitrogen in the mineral soil significantly increased with increasing precipitation from $51 \mathrm{~mol} \mathrm{~N} \mathrm{~m}^{-2}$ in stands with less than $600 \mathrm{~mm} \mathrm{yr}^{-1}$ to $70 \mathrm{~mol} \mathrm{~N} \mathrm{~m}^{-2}$ in stands with more than $900 \mathrm{~mm} \mathrm{yr}^{-1}$ (Fig. 4a). Maximum variation of nitrogen in the mineral soil was by a factor of two, while the pool of nitrogen in the organic layer varied stronger by a factor of eight (1.6-12.8 mol $\mathrm{N} \mathrm{m}^{-2}$ ). The higher the annual rainfall, the more nitrogen occurred in the mineral soil and the tendentious more $\mathrm{N}$ was in the organic layer on top of the soil, since its depth simultaneously increased. Hence, an upward shift of $\mathrm{N}$ from the mineral soil to the organic layer could not be found in this study.

Next to biological fixation, nitrogen is supplied to the soil by deposition of ammonium and nitrate. Emissions of $\mathrm{NO}_{x}$ and the deposition of $\mathrm{N}$ to European forests have actually increased (Dise \& Wright 1995). Total N-deposition is thereby dominated by wet deposition of $N$ (Lovett \& Lindberg 1993). These deposition inputs were observed to be even greater than soil leaching for $N$ in boreal (Ukonmaanaho \& Starr 2002) and beech forests (Rothe et al. 2002), leading to a net accumulation of nitrogen in the soil. Wet $\mathrm{N}$-deposition may partly explain the observed differences in nitrogen pools in beech forests across the investigated precipitation gradient, leading to higher nitrogen contents in the moist forest stands with high annual rainfall. Excess nitrogen deposition can change the nutrient balance and regulation processes, though, and lead to soil 
acidification (Grennfeldt \& Hultberg 1986, Aber et al. 1989, Bergkvist \& Folkeson 1992). Toxic effects of soil acidity and reactive aluminium may impede root uptake of $\mathrm{N}$, leading to further accumulation in the forest soil.

Soil $\mathrm{C} / \mathrm{N}$ ratios tended to be less favourable at the wet end of the transect (Fig. $3 \mathrm{~d}$ ). Soil acidity and a somewhat lower temperature in the moist forests stands of this study may have diminished nitrogen mineralisation (nitrification), despite great $\mathrm{N}$-pools in the mineral soil. Thus, we found higher $\delta^{15} \mathrm{~N}$-signatures in the leaf tissue of stands at the moister end of the transect, which indicate a higher $\mathrm{N}$-supply by ammonium than by nitrate in these forest stands $(r=0.52, p=0.05)$.
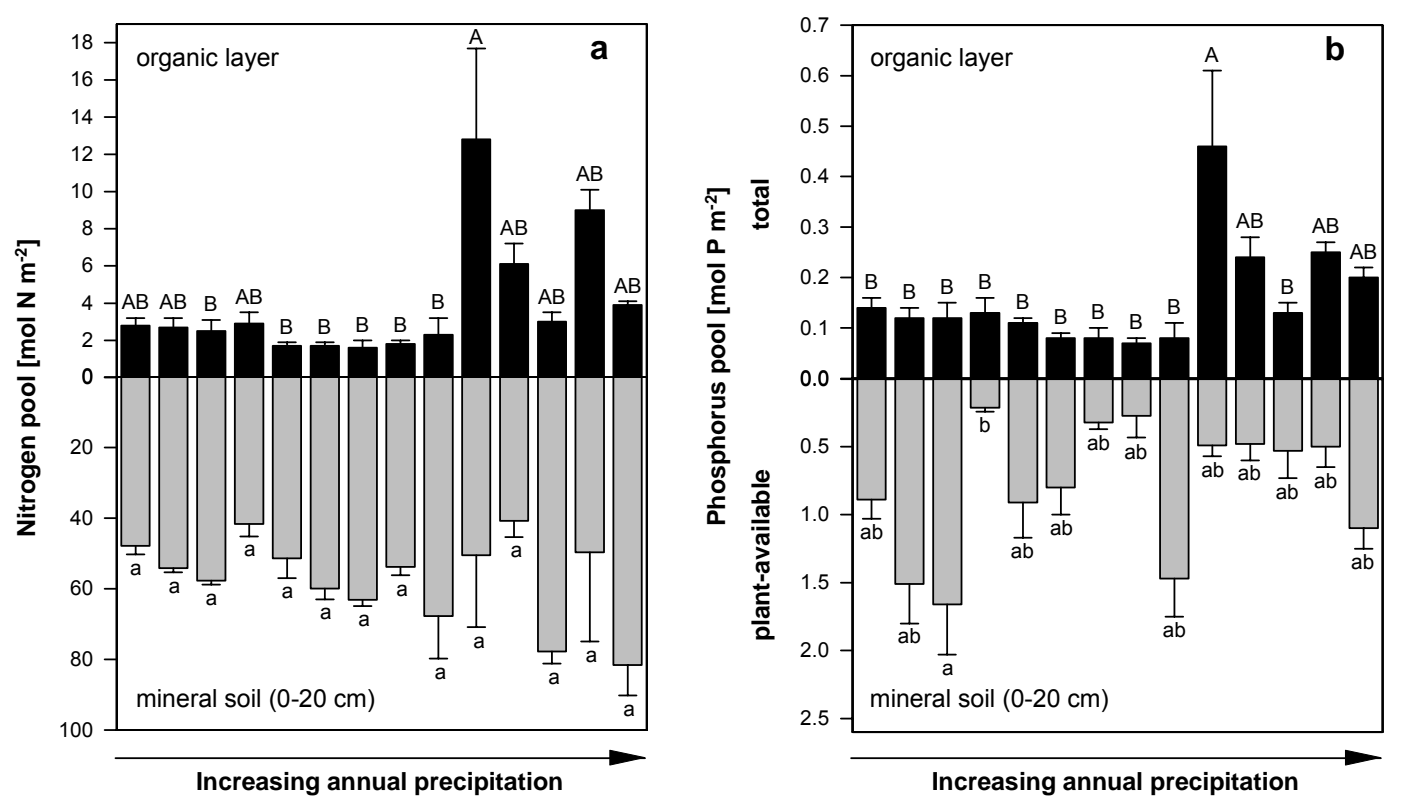

Figure 4. Nitrogen (a) and phosphorus (b) pools in the organic layer and the mineral soil $(0-20 \mathrm{~cm})$ of 14 beech stands on Triassic sandstone along a precipitation gradient in central Germany (mean and standard error of five samples per study site). Values relate to the entire organic layer (L, F, H layers). Different letters indicate significant differences among study sites.

The plant-available phosphorus (resin-exchangeable $\mathrm{P}, \mathrm{P}_{\mathrm{a}}$ ) pool in the mineral soil highly varied among the investigated forest stands by a factor of eight. A significant correlation of $\mathrm{P}_{\mathrm{a}}$ availability with annual rainfall was not found; although stands with less than $600 \mathrm{~mm} \mathrm{yr}^{-1}$ had $1.0 \mathrm{~mol} \mathrm{~Pa} \mathrm{~m}^{-2} 20 \mathrm{~cm}^{-1}$ and those with more than $900 \mathrm{~mm} \mathrm{yr}^{-1}$ had only $0.7 \mathrm{~mol} \mathrm{P}_{\mathrm{a}} \mathrm{m}^{-2} 20 \mathrm{~cm}^{-1}$ in the mineral soil (Fig. 4b). On the other hand, in stands with low annual rainfall only $0.13 \mathrm{mmol} \mathrm{P}_{\mathrm{t} \mathrm{m}} \mathrm{m}^{-2}$ were observed in the organic layer, but $0.19 \mathrm{mmol} \mathrm{P}_{\mathrm{t}} \mathrm{m}^{-2}$ in stands with high annual rainfall. The more $\mathrm{P}$ occurred in the mineral soil the smaller was the pool in the organic layer on top of the soil. Phosphorus seemed to be tendentious upward shifted in moist stands and downwards in dry stands of European beech. 
In relatively young temperate soils, nitrogen and not phosphorus is thought to be the limiting factor for plant growth (Reich \& Oleksyn 2004), indicated by a low N/P ratio. However, we found N/P ratios $>20 \mathrm{~mol} \mathrm{~mol}^{-1}$ in the organic layer, making a P-limitation in the investigated forest stands more likely (cf. Koerselman \& Meulemann 1996; Appendix: Table A1). The availability of phosphorus in temperate forest soils is mainly dependent on soil acidity (Johnson et al. 1998), which determines the size of the insoluble Ca-P and Al-P fractions, the amount of the organically-bound $\mathrm{P}$, and the mycorrhizal activity. The investigated moist forest stands on Triassic sandstone were more acidic than the dry stands, leading to a higher amount of phosphorus being unavailable bound as AI-P in the mineral soil and organically-bound in the thicker and less decomposed humus profiles, thus a lower availability of phosphorus.

Despite constricted differences in soil acidity of the generally rather nutrient-poor soils, some distinctions between the nutrient status of the investigated beech forests on Triassic sandstone along the investigated precipitation gradient could be found: the prominent role for differentiating the beech forests in terms of their soil nutrient status had the variable phosphorus pool and the content of bases in the mineral soil. High precipitation caused a higher leaching of soil bases and a fixation of phosphorus as AlP-complexes unavailable for plant nutrition. Especially the moist beech forests were therefore even stronger affected by $\mathrm{P}$-limitation than by $\mathrm{N}$-shortage that is currently deposited at high amounts. 


\subsection{Common garden experiment}

\section{Construction of the Göttingen Rhizolab Facility}

The Göttingen Rhizolab is an outdoor laboratory for the experimental study of growth dynamics of root systems of woody plants. It consists of eight drained containers $\left(1.8 \times 1.8 \times 2.2 \mathrm{~m}\right.$, for a total of $\left.7.1 \mathrm{~m}^{3}\right)$ arranged in two rows in a cellar-like subterranean setting. The containers are large enough to grow young trees under defined soil moisture and soil chemical conditions for several years without root limitation or intertree competition, while the plants are exposed to the outdoor environment. Each container is subterraneously accessible from two sides and filled with unfertilised medium-grained sand. Twenty-four Plexiglas mini-rhizotron tubes (length $2.05 \mathrm{~m}$, diameter $7 \mathrm{~cm}$ ) are installed in the upper part of each container horizontally in rows at six defined soil depths $(15.0,30.5,46.0,61.5,92.5,123.5 \mathrm{~cm}$ from the surface, four tubes per soil depth, arranged alternately in a criss-cross fashion; a total of 192 tubes in the Rhizolab). With this dense system of observation tubes, root growth and death can be monitored with high spatial resolution in the containers. Every mini-rhizotron tube is sealed permanently at the back end with a Plexiglas disc, while the front is covered with a removable plastic cover. The protruding part of the tube is covered with light-impermeable foil. The Rhizolab is covered by a mobile roof that automatically covers the young trees in the case of rainfall and thus allows precise soil moisture control, but exposes the plants to the natural insolation in the absence of rain.
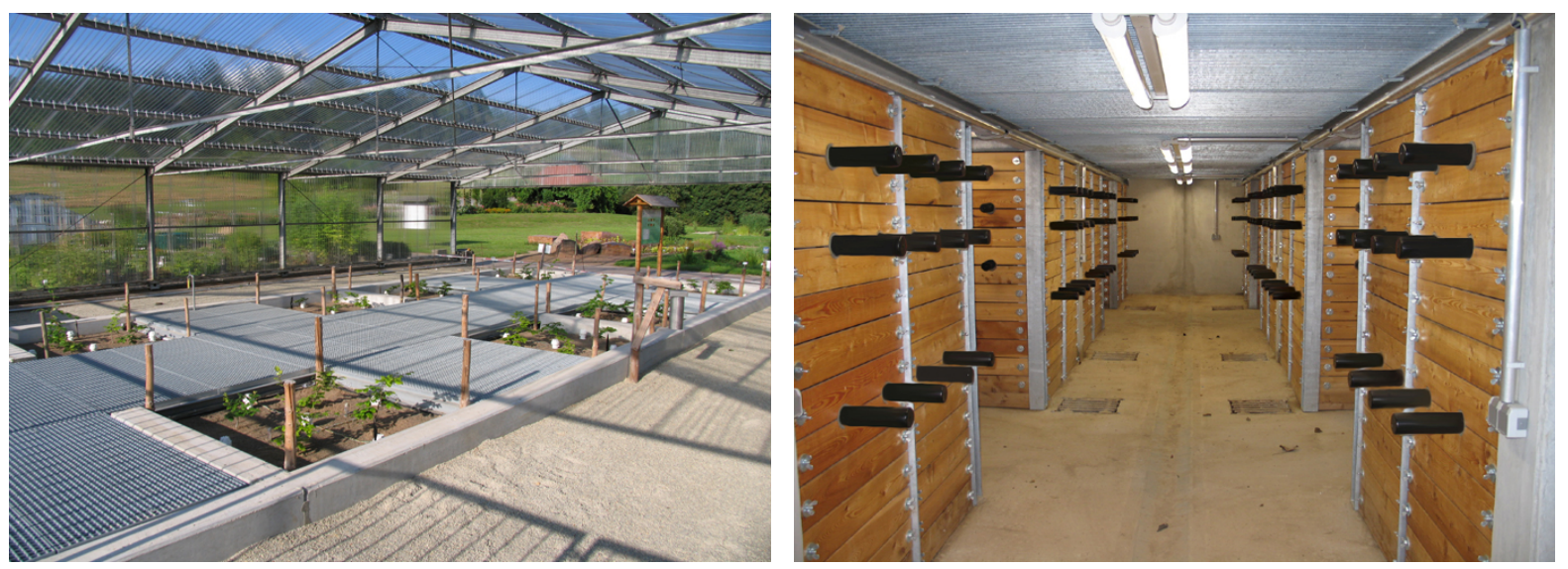

Figure 5. Aspects of the Göttingen Rhizolab Facility: containers aboveground covered by the mobile roof (left) and containers belowground with mini-rhizotron tubes (right). 


\section{Plant material}

Tree saplings for the experiment in the Rhizolab were selected in four Fagus sylvatica L. forests in the centre of the distribution range of beech in Germany to represent large differences in annual precipitation. The four stands were located along the investigated precipitation transect between the Solling Mountains and the Thuringian Basin. The forests were sufficiently comparable with respect to stand structure (closed canopy without major gaps) and age (100-120 yrs), soil chemical conditions (geological substrate: Triassic sandstone of Middle Bunter, formation: 'Hardegsen Folge') and temperature $\left(7.3\right.$ to $\left.8.0^{\circ} \mathrm{C}\right)$. Mean annual precipitation of the four sites decreased from the west to the east $\left(970,860,650\right.$, and $\left.520 \mathrm{~mm} \mathrm{yr}^{-1}\right)$, reflecting the transition from a more sub-oceanic to a more sub-continental climate in the rain shadow of the Solling and Harz mountains. The corresponding summer rainfall (May to September) decreased from 420 to $270 \mathrm{~mm} \mathrm{yr}^{-1}$. In these stands, beech saplings grown from seeds of a natural masting event were excavated, cultivated, and used as experimental plants in the Rhizolab.

\section{Experimental design}

In the experiment, two soil moisture levels were maintained: a dry (5 vol. \%) and a moist treatment (10 vol.\%; control), each replicated fourfold. Treatments were arranged by random in the Rhizolab. In every container, four trees (one per origin) were planted in a randomised block design at equal distances to each other. Summer drought periods of 16-18 wks subsequent to the first phase of leaf growth was simulated, such as may occur in very dry years in central Germany. The experiment took place from May 2005 to August 2006, with the 2006 growing season being characterised by a higher air temperature $\left(20.0^{\circ} \mathrm{C}\right.$ vs. $\left.18.5^{\circ} \mathrm{C}\right)$ and by a higher vapour pressure deficit $(9.0 \mathrm{hPa}$ vs. 7.5 hPa; Fig. 6).
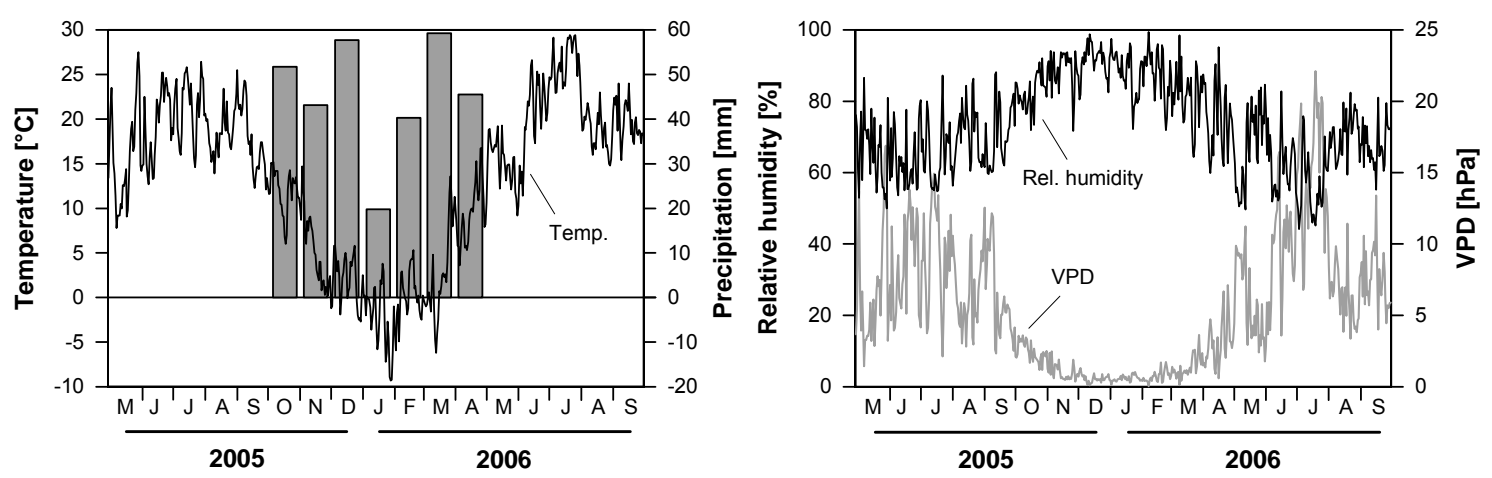

Figure 6. Climatic conditions during the experiment in the Göttingen Rhizolab Facility from May 2005 to September 2006. Shown are air temperature, relative humidity and vapour pressure deficit (VPD) during the year and the monthly sum of precipitation for the period from October 2005 to April 2006 without experimental soil moisture treatment. 


\section{Genetic characterization}

To characterise genetic differences between the four investigated beech populations, isozyme analyses of ten enzymes of dormant buds were carried out (ISOGEN, Reckershausen, Germany). The genetic diversity ( $v)$, the expected heterozygosity $\left(H_{e}\right)$, and a comparison between the genetic structures according to the genetic distance $\left(d_{0}\right)$ were calculated with the program GSED (Gillet 1994; details in Chapter V).

\section{Estimation of root lifespan and turnover}

For quantifying root growth and death, mini-rhizotron images of the roots were collected with a scanner system ( $\mathrm{Cl}-600, \mathrm{CID}$ Inc., USA). Pictures were recorded every second week at the entire surface of the mini-rhizotron tubes from May 2005 to August 2006. In order to determine temporal changes in root length, image sequences were analysed with the computer program WinRHIZOTron (Régent, Canada). Root order as defined by Pregitzer et al. (2002) was determined visually. Root survivorship curves were calculated using the Weibull distribution for right censored data with the package SAS, version 8.2 (Cary, USA). The Weibull distribution for right censored data is a reliability analysis, which defines the probability of an individual of a root population to survive until at least time $t$. Relative production of fine roots were calculated from the proportion of increase to the standing stock of fine root length. Turnover of fine roots was referred to as the proportion of fine root length decrease to fine root length increase (details in Chapter V).

\section{Determination of biomass allocation patterns and morphology}

After harvest in mid-August 2006, leaf, shoot, coarse root, and fine root mass were weighed. Maximum rooting width and depth in the container were measured. Total fine root area and specific root area (SRA), total leaf size and specific leaf area (SLA) were determined with a flat-bed scanner and the programs WinRHIZO and WinFOLIA, respectively (Régent Instruments, Quebec, Canada). Grounded samples were analysed for total carbon and nitrogen with a $\mathrm{C} / \mathrm{N}$ elemental analyser. The carbon isotope signature of plant dry mass was analysed by mass spectroscopy (Delta plus, ThermoFinnigan, USA) at the Centre for Stable Isotope Research and Analysis (KOSI) of the University of Göttingen (details in Chapter V). 


\title{
Chapter 3
}

\author{
Leaf size and leaf area index \\ in Fagus sylvatica forests: \\ competing effects of precipitation, \\ temperature and nitrogen availability
}

IC Meier · Ch Leuschner

Ecosystems (2008, accepted) 


\section{Abstract}

Plants across diverse biomes tend to produce smaller leaves and a reduced total leaf area when exposed to drought. For mature trees of a single species, however, the leaf area-water supply relationship is not well understood. We tested the paradigm of leaf area reduction upon drought by a transect study with 14 mature Fagus sylvatica forests along a steep precipitation gradient (970 to $520 \mathrm{~mm} \mathrm{yr}^{-1}$ ) by applying two independent methods of leaf size determination. Contrary to expectation, average leaf size in dry stands (520-550 $\mathrm{mm} \mathrm{yr}^{-1}$ ) was about 40\% larger and SLA was higher than in moist stands (910-970 $\left.\mathrm{mm} \mathrm{yr}^{-1}\right)$. As a result of increased leaf sizes, leaf area index significantly increased from the high- to the low-precipitation stands. Multiple regression analyses suggested that average leaf size was primarily controlled by temperature, whereas the influence of soil moisture and soil $\mathrm{C} / \mathrm{N}$ ratio was low. Summer rainfall of the preceding year was the most significant predictor of total leaf number. We assume that leaf expansion of beech was independent of water supply, because it takes place in May with ample soil water reserves along the entire transect. In contrast, bud formation, which determines total leaf number, occurs in mid-summer, when droughts are severest. We conclude that leaf expansion and stand leaf area of beech along this precipitation gradient are not a simple function of water availability, but are controlled by several abiotic factors including spring temperature and possibly also nitrogen supply, which both tend to increase towards drier sites, thus overlaying any negative effect of water shortage on leaf development.

Keywords: adult trees, bud formation, drought, European beech, LAl, leaf expansion, leaf population, precipitation gradient 


\section{Introduction}

There is a vital debate on how temperate trees may respond to an increased frequency and severity of summer droughts as is predicted in recent climate change scenarios for parts of Central Europe (IPCC 2001, 2007, Rowell \& Jones 2006). This question is particularly relevant for economically important tree species such as European beech (Fagus sylvatica L.). This species has a sub-oceanic distribution and exhibits a number of physiological and morphological traits that characterise it as comparatively droughtsensitive (Backes \& Leuschner 2000, Granier et al. 2007). Therefore, reduced summer rainfall could threaten beech forests in regions of Central Europe, where this species is actually growing near its drought limit.

Numerous laboratory experiments with herbaceous plants and tree seedlings have shown that leaf area reduction is a common response to soil water shortage (e.g., Fischer \& Turner 1978, Begg 1980, Poorter 1989, Lof \& Welander 2000, Pedrol et al. 2000 , Otieno et al. 2005), thereby reducing the transpiring surface area and avoiding severe decreases in cell water potential and turgor (Hinckley et al. 1981, Kozlowski \& Pallardy 1997). Next to the environmental control on leaf area development, genotypic variation may also interfere. Tree leaf area and stand leaf area index (LAl, the onesided cumulative surface area of all leaves per unit ground area) are of paramount importance for forest biogeochemical fluxes because radiation interception, productivity, canopy conductance and stand transpiration are all closely linked to LAI (Gholz 1990, Bréda \& Granier 1996, Kozlowski \& Pallardy 1997, Welander \& Ottoson 1997).

If the response of trees and forests to a possibly drier climate is to be predicted, longterm adaptive responses and highly flexible resource allocation patterns in these longlived plants must be taken into account. This makes simple extrapolation from laboratory seedling or sapling studies to mature forests difficult if not impossible. Much more realistic results can be expected from large manipulation experiments in the field such as throughfall exclusion experiments, where a reduced precipitation is simulated (e.g., Wullschleger \& Hanson 2006). However, due to high costs and restrictions in personnel, most large-scale water manipulation experiments in forests suffer from missing replication and short duration with the consequence that adaptive responses of trees are only rarely covered. Another source of information can be comparative studies in forest stands along precipitation gradients which may provide valuable additional information for understanding long-term tree adaptation to drought if the sites are carefully selected and other environmental factors are kept sufficiently constant. 
Studies on leaf area index and leaf morphology changes in mature forest stands of a single tree species along precipitation or soil moisture gradients have only rarely been conducted so far. The existing gradient studies in forests focussing on the leaf areawater supply relationship referred to long gradients and typically included a tree species turnover between the moist and dry ends of the gradient (e.g., Grier \& Running 1977, Hinckley et al. 1981, Runyon et al. 1994, Turner 1994, Jose \& Gillespie 1997, Cunningham et al. 1999, Reich et al. 1999, Wright et al. 2004). This kind of data may allow general conclusions on how water shortage affects forest leaf area within biomes, but it gives no insight into a tree species' adaptive potential with respect to leaf area development and leaf morphology.

European beech forms mono-specific stands under a broad range of soil chemical and hydrological conditions, from highly acid to basic soils (Leuschner et al. 2006a), and from low to high rainfall regimes. Hence, this species provides unique opportunities for investigating a tree species' response to water availability in the field by covering a broad range of soil moisture or rainfall conditions. In this study, we compared the leaf area development of 14 mature beech forests of similar age and structure along a steep precipitation gradient (520 to $970 \mathrm{~mm} \mathrm{yr}^{-1}$ ), while other environmental factors were by far less variable. We aimed at testing the paradigm of a decrease in LAI and mean leaf size with declining rainfall for mature trees of a single species, thereby improving our understanding of long-term adaptive drought responses of temperate trees.

\section{Materials and Methods}

\section{Study area and forest stands}

The study was conducted in the centre of the distribution area of Fagus sylvatica in southern Lower Saxony, northern Thuringia and south-western Saxony Anhalt in central Germany. Fourteen mature beech forests with comparable stand structure were selected for study (Table 1). The sites were chosen along a $150 \mathrm{~km}$ long WNW-ESE transect in level to slightly sloping terrain at elevations of 230 to $440 \mathrm{~m}$ a.s.l. All stands grew on the same geological substrate (Triassic sandstone of Middle Bunter) to enhance comparability of soil chemical conditions. Mean annual temperature was $7.8^{\circ} \mathrm{C}$ along the transect, with a tendency for slightly higher temperatures in the eastern, more continental section of the transect. Mean annual precipitation decreased from the west $\left(970 \mathrm{~mm} \mathrm{yr}^{-1}\right)$ to the east $\left(520 \mathrm{~mm} \mathrm{yr}^{-1}\right)$, reflecting the transition from a 


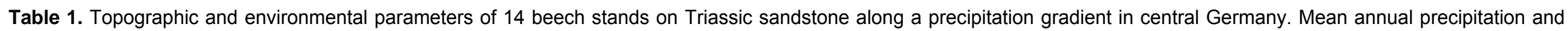
temperature were derived from weather station data corrected for altitude. Different letters indicate significant differences between the study sites.

\begin{tabular}{|c|c|c|c|c|c|c|c|c|c|c|c|}
\hline $\begin{array}{c}\text { Site } \\
\#\end{array}$ & Location & Coordinates & $\begin{array}{l}\text { Altitude } \\
\text { [m a.s.l.] }\end{array}$ & Exposition & $\begin{array}{c}\text { Inclination } \\
{\left[{ }^{\circ}\right]}\end{array}$ & $\begin{array}{c}\text { Mean annual } \\
\text { precipitation } \\
{\left[\mathrm{mm} \mathrm{yr}^{-1}\right]}\end{array}$ & $\begin{array}{c}\text { Soil moisture } \\
\text { in May } \\
\text { [vol.\%] }\end{array}$ & $\begin{array}{c}\text { Mean annual } \\
\text { temperature } \\
{\left[{ }^{\circ} \mathrm{C}\right]}\end{array}$ & $\begin{array}{c}\text { Temperature } \\
\text { in May }{ }^{1} \\
{\left[{ }^{\circ} \mathrm{C}\right]}\end{array}$ & $\mathrm{pH}\left(\mathrm{H}_{\mathbf{2}} \mathrm{O}\right)^{2}$ & $\begin{array}{l}\text { C/N ratio } \\
{\left[\mathrm{mol} \mathrm{mol}^{-1}\right]}\end{array}$ \\
\hline 1 & Hellental & $09^{\circ} 36^{\prime} 51^{\circ} 48^{\prime}$ & 400 & NW & 9.1 & 970 & $18.4^{\mathrm{A}}$ & 7.3 & $8.1^{\mathrm{e}}$ & $4.0^{A B}$ & $21.1^{\text {bcde }}$ \\
\hline 2 & Limker Strang & $09^{\circ} 40^{\prime} 51^{\circ} 43^{\prime}$ & 380 & NW & 4.0 & 950 & $17.7^{\mathrm{A}}$ & 7.4 & $8.2^{\mathrm{e}}$ & $3.8^{\mathrm{BC}}$ & $23.3^{a b c}$ \\
\hline 3 & Storenhai & $09^{\circ} 26^{\prime} 51^{\circ} 44^{\prime}$ & 340 & NW & 4.3 & 910 & $19.3^{A}$ & 7.7 & $8.8^{\mathrm{de}}$ & $4.2^{\mathrm{AB}}$ & $20.3^{\text {bcde }}$ \\
\hline 4 & Lamspringe & $10^{\circ} 02^{\prime} 51^{\circ} 57^{\prime}$ & 250 & SW & 7.4 & 860 & $23.8^{A}$ & 8.2 & $9.1^{\mathrm{cde}}$ & $3.6^{C}$ & $25.7^{\mathrm{a}}$ \\
\hline 5 & Totenberg & $09^{\circ} 39^{\prime} 51^{\circ} 32^{\prime}$ & 410 & NE & 1.6 & 820 & $20.4^{\mathrm{A}}$ & 7.3 & $7.9^{e}$ & $4.1^{A B}$ & $26.4^{a}$ \\
\hline 6 & Jägerborn & $09^{\circ} 44^{\prime} 51^{\circ} 19^{\prime}$ & 440 & NW & 6.7 & 800 & $18.7^{\mathrm{A}}$ & 7.1 & $8.0^{\mathrm{de}}$ & $4.4^{\mathrm{AB}}$ & $19.7^{\text {bcde }}$ \\
\hline 7 & Knüll & $10^{\circ} 01^{\prime} 51^{\circ} 29^{\prime}$ & 250 & $\mathrm{~N}$ & 1.2 & 680 & $19.6^{A}$ & 8.2 & $9.7^{b c}$ & $4.5^{A B}$ & $17.1^{\mathrm{e}}$ \\
\hline 8 & Gerterode & $10^{\circ} 29^{\prime} 51^{\circ} 23^{\prime}$ & 340 & SW & 9.5 & 670 & $20.1^{\mathrm{A}}$ & 7.7 & $8.3^{\mathrm{de}}$ & $5.6^{A}$ & $20.9^{\text {bcde }}$ \\
\hline 9 & Herrenholz & $10^{\circ} 27^{\prime} 51^{\circ} 32^{\prime}$ & 320 & $S$ & 4.3 & 650 & $24.4^{\mathrm{A}}$ & 7.8 & $8.6^{\mathrm{cd}}$ & $4.6^{\mathrm{A}}$ & $19.3^{\mathrm{cde}}$ \\
\hline 10 & Hardt & $10^{\circ} 52^{\prime} 51^{\circ} 24^{\prime}$ & 320 & NW & 4.8 & 580 & $19.1^{\mathrm{A}}$ & 7.8 & $9.0^{\mathrm{bcd}}$ & $5.3^{A}$ & $19.1^{\text {cde }}$ \\
\hline 11 & Kommissionsbuchen & $11^{\circ} 27^{\prime} 51^{\circ} 10^{\prime}$ & 280 & NW & 2.3 & 580 & $23.9^{A}$ & 8.0 & $9.3^{a b}$ & $3.9^{A B}$ & $23.0^{\mathrm{abcd}}$ \\
\hline 12 & Hohelinde & $11^{\circ} 25^{\prime} 51^{\circ} 20^{\prime}$ & 230 & SW & 5.2 & 550 & $22.8^{\mathrm{A}}$ & 8.3 & $9.7^{\mathrm{a}}$ & $4.0^{A B}$ & $23.8^{\mathrm{ab}}$ \\
\hline 13 & Ziegelroda & $11^{\circ} 26^{\prime} 51^{\circ} 19^{\prime}$ & 240 & SE & 3.0 & 550 & $21.5^{\mathrm{A}}$ & 8.3 & $9.5^{\mathrm{ab}}$ & $4.6^{\mathrm{A}}$ & $20.1^{\text {bcde }}$ \\
\hline 14 & Allstedt & $11^{\circ} 25^{\prime} 51^{\circ} 22^{\prime}$ & 280 & NW & 1.3 & 520 & $16.1^{\mathrm{A}}$ & 8.0 & $9.0^{\mathrm{bcd}}$ & $4.6^{\mathrm{A}}$ & $18.6^{\mathrm{de}}$ \\
\hline
\end{tabular}

${ }^{1}-$ in $2004,{ }^{2}-0-10 \mathrm{~cm}$ of mineral soil 
sub-oceanic to a more sub-continental climate in the rain shadow of the Solling and Harz mountains. The corresponding summer rainfall (May to September) decreased from 420 to $270 \mathrm{~mm} \mathrm{yr}^{-1}$. As in other rainfall transects, temperature and nutrient supply changed along the transect as well. However, the variability of temperature, $\mathrm{pH}$, and $\mathrm{C} / \mathrm{N}$ ratio was much smaller than that of precipitation (see table 1 ), which nearly doubled from the east to the west. For simplicity, we talk of a precipitation gradient hereafter.

Selection criteria for the stands were (i) closed canopy without major gaps, (ii) evenaged stand structure (100 to 140 yrs old; extremes 90-157 yrs), (iii) no significant presence of other tree species, and (iv) 175 to 250 stems per hectare. The stands were founded either from seeds or from planting of seedlings of autochthonous (local) origin. Typically, beech formed a single closed canopy (mono-layer) with a second tree layer and shrubs being mostly absent. Forest management activities in the stands had not been conducted for at least seven yrs, in most cases for more than ten yrs prior to the study. Most of the stands fitted to this scheme. However, a higher total stem density existed in stand \#14 where 233 stems ha $^{-1}$ reached the upper canopy, and 111 thinner beech trees formed a sparse second layer. Mean tree height in the upper canopy layer was $34 \mathrm{~m}$ in the 14 stands (extremes: $30-38 \mathrm{~m}$ ), mean breast height diameter was $41 \mathrm{~cm}(32-51 \mathrm{~cm}$; Table 2). The sites were not affected by compensatory liming activities of forestry except for stand \#6 (eight yrs ago) and \#3 (13 yrs ago).

We were not able to monitor soil moisture continuously at the 14 sites; however, TDR measurements of soil moisture were conducted every second month at $0-20 \mathrm{~cm}$ soil depth in all stands. In addition, one beech stand each at the moist and dry end of the transect was equipped with continuously logging TDR- and tensiometer stations in 2003 (15-20 cm depth; data for the moist site according to Meesenburg (unpubl.)). According to the occasional and continuous soil moisture measurements, the lower rainfall at the dry end is corresponding to lower absolute soil moisture minima and a longer duration of low soil water contents in summer in comparison to the sites at the moist end of the transect (Fig. 1a and b). The nitrogen content and the $\mathrm{C} / \mathrm{N}$ ratio of the mineral topsoil $(0-10 \mathrm{~cm})$ were analysed in five samples per stand.

We used two independent approaches to determine leaf size in the canopy of the stands, (a) by analysing fresh fallen leaves collected in autumn in litter buckets, and (b) by investigating leaves harvested with a crossbow in the upper sun canopy in midsummer. 
Table 2. Stand structural characteristics and specific leaf area (SLA) of 14 beech forests on Triassic sandstone in 2003 and 2004 along a precipitation gradient in central Germany.

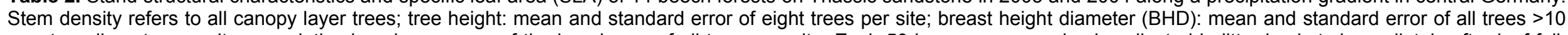
$\mathrm{cm}$ stem diameter per site; cumulative basal area: sum of the basal area of all trees per site. Each 50 leaves were randomly collected in litter buckets immediately after leaf fall; values given are mean and standard error of $n=$ ten buckets per site; total number of leaves analysed per site $=500$. Different Greek letters indicate significant differences between the study years and different Latin letters mark significant differences between the sites during a given study year. $n$.i. = not investigated.

\begin{tabular}{|c|c|c|c|c|c|c|c|c|c|c|c|}
\hline \multirow[b]{3}{*}{ Site \# } & \multirow{3}{*}{$\begin{array}{c}\text { Stand age } \\
{[\mathrm{a}]} \\
\text { mean }\end{array}$} & \multirow{3}{*}{$\begin{array}{l}\text { Stem density } \\
{\left[\mathrm{n} \mathrm{ha}^{-1}\right]} \\
\text { mean }\end{array}$} & \multirow{2}{*}{\multicolumn{2}{|c|}{$\begin{array}{c}\text { Tree height } \\
{[\mathrm{m}]}\end{array}$}} & \multirow{2}{*}{\multicolumn{2}{|c|}{$\begin{array}{l}\text { BHD } \\
{[\mathrm{cm}]}\end{array}$}} & \multirow{3}{*}{$\begin{array}{c}\text { Cumulative } \\
\text { basal area } \\
{\left[\mathrm{m}^{2} \mathrm{ha}^{-1}\right]} \\
\text { mean }\end{array}$} & \multicolumn{4}{|c|}{ Specific leaf area $\left[\mathrm{m}^{2} \mathrm{~kg}^{-1}\right]$} \\
\hline & & & & & & & & 2003 & & 2004 & \\
\hline & & & mean & s.e. & mean & s.e. & & mean & s.e. & mean & s.e. \\
\hline 1 & 136 & 189 & $32.9^{A B}$ & 0.9 & $36.1^{a}$ & 3.1 & 30.3 & ${ }^{\alpha} 20.6^{A B C}$ & 0.2 & $\beta_{18.3^{\text {cde }}}$ & 0.3 \\
\hline 2 & 153 & 189 & $33.7^{\mathrm{AB}}$ & 0.7 & $46.0^{a}$ & 3.9 & 35.0 & ${ }^{\mathrm{a}} 17.4^{\mathrm{B}}$ & 0.2 & $\beta 15.8^{e}$ & 0.3 \\
\hline 3 & 126 & 178 & $37.1^{\mathrm{A}}$ & 1.5 & $47.1^{a}$ & 2.7 & 32.5 & ${ }^{a} 20.1^{B C}$ & 0.2 & $\beta 19.0^{\text {bcde }}$ & 0.3 \\
\hline 4 & 99 & 189 & $31.6^{\mathrm{AB}}$ & 0.5 & $40.5^{a}$ & 3.4 & 30.6 & ${ }^{a} 20.9^{A B C}$ & 0.2 & ${ }^{a} 20.3^{\text {abcd }}$ & 0.8 \\
\hline 5 & 157 & 178 & $32.4^{A B}$ & 0.8 & $39.0^{a}$ & 4.0 & 31.8 & ${ }^{\alpha} 20.7^{A B C}$ & 0.6 & ${ }^{\beta} 17.4^{\mathrm{de}}$ & 0.5 \\
\hline 6 & 143 & 144 & $33.3^{A B}$ & 0.2 & $46.2^{a}$ & 3.8 & 30.5 & ${ }^{a} 21.7^{A B}$ & 0.4 & ${ }^{\beta} 18.6^{\text {cde }}$ & 0.2 \\
\hline 7 & 90 & 200 & $33.1^{A B}$ & 0.4 & $35.5^{a}$ & 2.3 & 21.3 & ${ }^{\alpha} 20.8^{A B C}$ & 0.5 & ${ }^{\alpha} 20.7^{\text {abcd }}$ & 0.6 \\
\hline 8 & 132 & 256 & $32.6^{A B}$ & 1.4 & $31.8^{a}$ & 2.4 & 27.4 & ${ }^{\alpha} 24.0^{A}$ & 0.5 & ${ }^{a} 22.3^{a b c}$ & 0.9 \\
\hline 9 & 98 & 200 & $35.0^{A B}$ & 0.4 & $33.5^{a}$ & 3.8 & 27.3 & ${ }^{\alpha} 21.5^{A B}$ & 0.6 & ${ }^{\alpha} 19.8^{a b c d}$ & 0.6 \\
\hline 10 & 139 & 189 & $37.8^{A}$ & 1.6 & $47.9^{a}$ & 2.5 & 37.7 & ${ }^{\alpha} 22.2^{A B}$ & 0.5 & ${ }^{\mathrm{a}} 23.1^{\mathrm{ac}}$ & 0.6 \\
\hline 11 & 99 & 289 & $34.0^{A B}$ & 1.0 & $38.4^{a}$ & 2.4 & 36.8 & ${ }^{\alpha} 22.2^{A B}$ & 0.9 & $\beta 19.8^{\text {acd }}$ & 0.6 \\
\hline 12 & 131 & 200 & $29.6^{B}$ & 1.3 & $45.1^{a}$ & 2.2 & 33.1 & ${ }^{\beta} 21.4^{A B}$ & 0.5 & ${ }^{\mathrm{a}} 23.0^{\mathrm{ac}}$ & 0.5 \\
\hline 13 & 132 & 167 & $35.8^{A B}$ & 0.9 & $51.3^{a}$ & 3.5 & 39.4 & $22.4^{\mathrm{AB}}$ & 0.6 & n.i. & \\
\hline 14 & 123 & 344 & $32.7^{A B}$ & 0.5 & $33.7^{a}$ & 2.4 & 48.8 & ${ }^{\alpha} 23.7^{A B}$ & 0.9 & ${ }^{\beta} 21.2^{c}$ & 0.6 \\
\hline
\end{tabular}



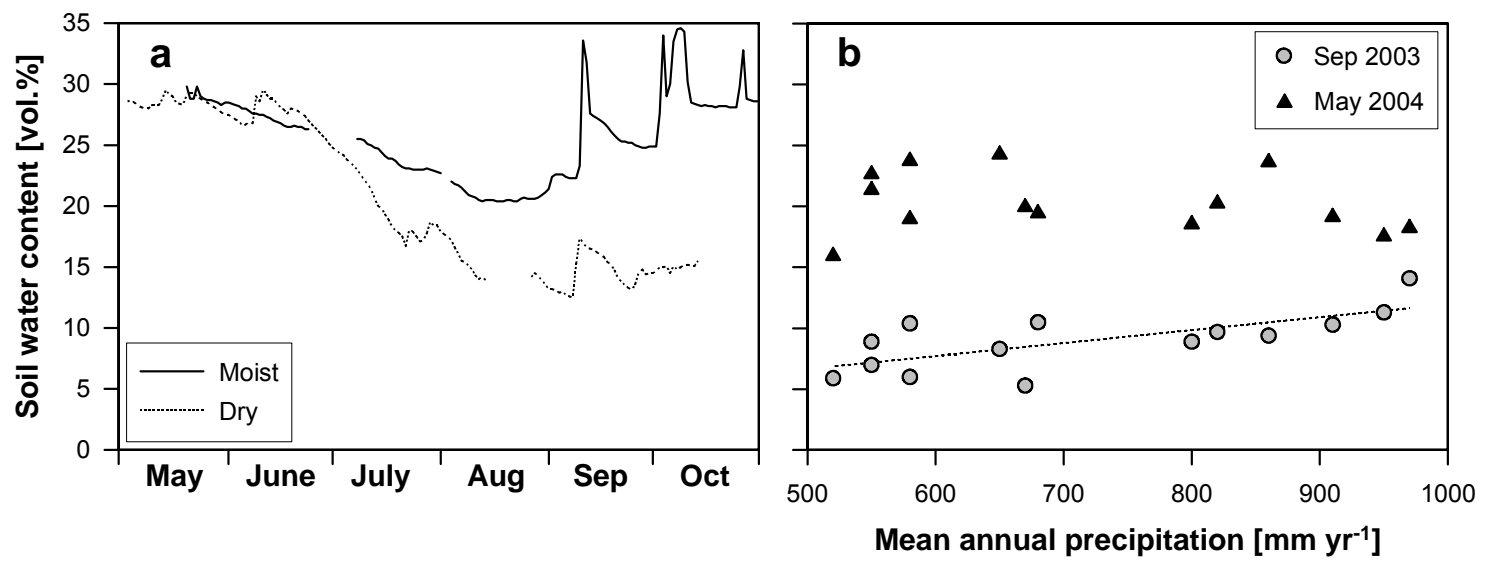

Figure 1a. Soil water content $(15-20 \mathrm{~cm})$ in beech stands at the moist $\left(>950 \mathrm{~mm} \mathrm{yr}^{-1}\right)$ and the dry end $\left(<550 \mathrm{~mm} \mathrm{yr}^{-1}\right)$ of the investigated precipitation gradient in central Germany. Values given are data for the growing season in the dry year 2003. Data for the moist beech stand according to Meesenburg (unpubl.) and for the dry beech stand according to Burk (2006). Figure 1b. Relationship between mean annual precipitation and soil water content $(0-20 \mathrm{~cm})$ in spring and late summer in 14 beech stands along the precipitation gradient in central Germany (mean of ten sampling points per study site). Values given are data for September 2003 at the end of a dry summer and for May 2004 at the time of leaf flush (Sep 2003: $y=1.3+0.01 x, r^{2}=0.50, p=0.002$; May 2004: $\left.r^{2}=0.06, p=0.21\right)$.

The leaf area measurements with leaf litter took place in 2003 and 2004, two years with a highly contrasting precipitation and temperature regime. The summer 2003 was the hottest summer in the region since 1901 with a by $20 \%$ lower annual precipitation than the long-term average in the study area. In contrast, the summer 2004 was by $20 \%$ wetter than the average record for the study area.

\section{Determination of leaf area, leaf mass and leaf morphology}

Stand leaf mass ( $\mathrm{M}_{\mathrm{l}}$, which equals annual leaf production) and leaf area index (LAl) were recorded by litter trapping in 2003 and 2004 in all 14 stands. Each ten litter buckets (aperture: $0.28 \mathrm{~m}^{2}$ ) per stand were installed in rectangular plots of $4 \mathrm{~m} \times 20 \mathrm{~m}$ with the buckets being positioned systematically in a grid with $4 \mathrm{~m}$ mesh width. The buckets had a perforated bottom and stood $10 \mathrm{~cm}$ above the forest floor with the opening being at $40 \mathrm{~cm}$ height. The placing of the rectangular $4 \mathrm{~m} \times 20 \mathrm{~m}$ sampling plots in the stands followed the stand homogeneity criteria defined above; the exact position was defined by a random procedure. All 140 litter buckets were emptied once immediately after the autumnal litter fall. At the most, $10 \%$ of total canopy leaf mass was subject to pre-senescent leaf litter fall in August or September, thus remained in the buckets for 6 to 10 weeks. According to Albers et al. (2004) and Heim \& Frey (2004), 6 to $12 \%$ of leaf mass are lost in the first six to ten wks of decomposition in beech leaves. Thus a maximum error of $1.2 \%$ in leaf mass calculation can be expected due to this type of error. With regard to mass loss, differences between moist and dry 
sites should be small, since litter quality typically is a better predictor of litter decomposition than climate at the beginning of the decomposition process (Aerts 1997, Berg et al. 2000, Heim \& Frey 2004).

The leaf samples were stored at $6^{\circ} \mathrm{C}$ and sorted into leaf and non-leaf fractions. Fifty leaves per bucket were randomly selected and analysed for their leaf area using a flatbed scanner and the computer program Win FOLIA (Régent Instruments, Quebec, Canada). Subsequently, the total leaf mass was dried $\left(70^{\circ} \mathrm{C}, 48 \mathrm{~h}\right)$ and weighed and the specific leaf area (SLA) calculated. LAI was obtained by multiplying $M_{1}$ with the stand average of SLA.

Leaves of the upper sun canopy were harvested in July/August 2005 and 2006 with a crossbow in ten (2005: seven) of the 14 stands. Eight (2005: six) branches were collected per stand and a total of 30 (180) randomly selected leaves analysed for size. All leaves of a branch were mixed and the eight (six) mixed samples were dried $\left(70^{\circ} \mathrm{C}\right.$, $48 \mathrm{~h}$ ) and weighed, and the specific leaf area (SLA) calculated. The dried samples were ground and the carbon isotope signature of plant dry mass was analysed by mass spectroscopy (Delta plus, ThermoFinnigan, USA) in the Centre for Stable Isotope Research and Analysis (KOSI) of the University of Göttingen.

\section{Statistical analyses}

All data was tested for probability of fit to normal distribution by a Shapiro-Wilk test. In case of Gaussian distribution of the data, study site means were compared with a Scheffé test. Weibull functions were fitted to the size data of the leaf populations of the stands. For identifying the most influential gradients related to environmental or stand structural parameters in the 14 stands, we applied a principal components analysis to factors that were found to be related to leaf morphology, but were mostly independent of each other (precipitation, $\mathrm{C} / \mathrm{N}$, temperature, stem density, stand age). Subsequently, we employed stepwise multiple regression analyses with backward variable elimination to quantify the effect of the putative key influential factors during leaf flush in May or during bud formation in August of the preceding year (climate, soil chemistry or stand structure). These analyses were accompanied by single-factor linear regression analyses with the key climate, soil chemistry or stand structure parameters. Significance was determined at $p<0.05$ in all tests. 


\section{Results}

\section{Total number of leaves, average leaf size, and leaf morphology}

According to the litter bucket data, the total number of beech leaves per ground area ranged from 2700 to $5000 \mathrm{~m}^{-2}$ in the 14 stands (Fig. 2b). While the number remained constant across the transect in 2004 , it decreased by about $15 \%$ from the high$\left(970 \mathrm{~mm} \mathrm{yr}^{-1}\right)$ to the low-precipitation stands $\left(520 \mathrm{~mm} \mathrm{yr}^{-1}\right)$ in 2003. In contrast, average leaf size increased in all years along this transect from the high- to the low-precipitation stands as evidenced by both the leaf litter data and the sun canopy leaves harvested in mid-summer (Fig. 2a, 3a).
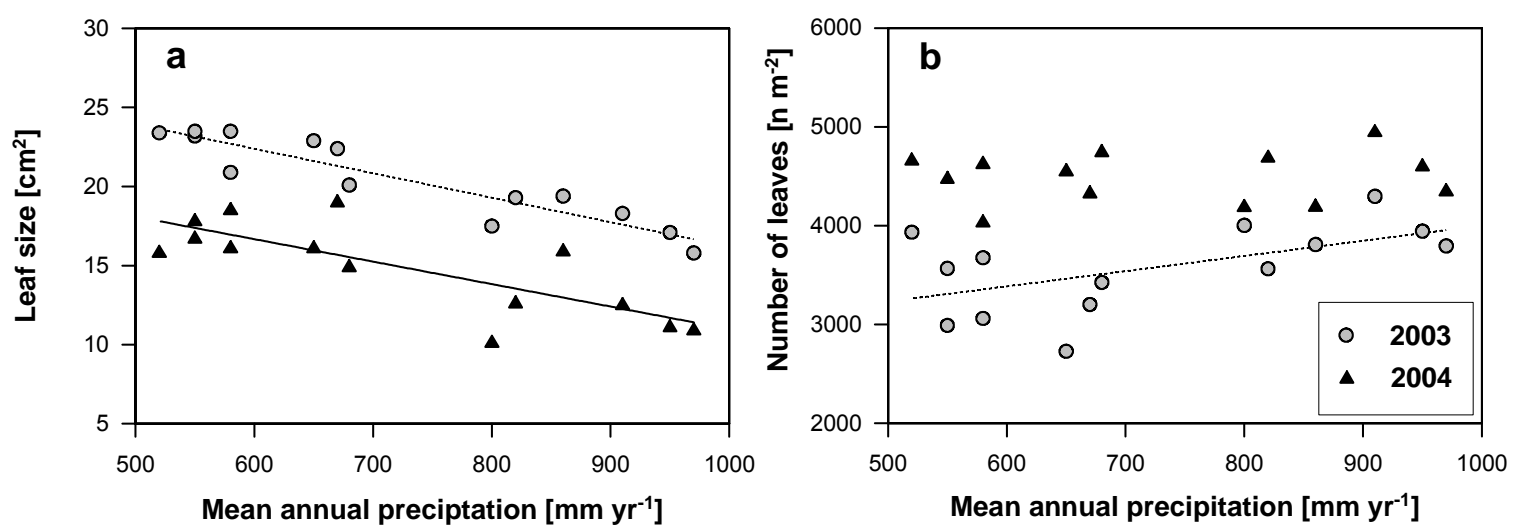

Figure 2a, b. Relationship between mean annual precipitation and average leaf size or number of leaves determined at the time of leaf fall in 14 mature beech stands along a precipitation gradient in central Germany (mean of 500 leaves randomly collected from ten litter buckets per site). Values given are data for the dry year 2003 and the moist year 2004 (leaf size 2003: $y=31.7-0.02 x, r^{2}=0.85, p<0.001 ; 2004$ : $y=25.5-0.01 x, r^{2}=0.61, p=0.001$; number of leaves 2003: $y=2462+1.5 x, r^{2}=0.31, p=0.02 ; 2004: r^{2}=0.01$, $\mathrm{p}=0.40)$.
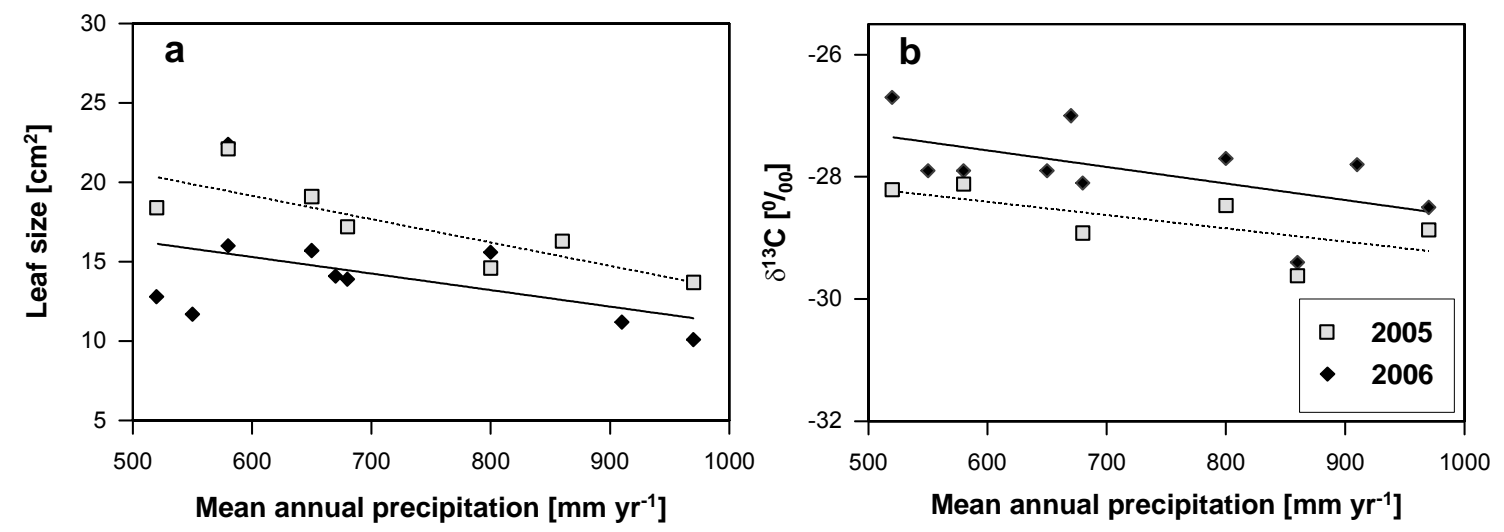

Figure 3a, b. Relationship between mean annual precipitation and average leaf size or $\delta^{13} \mathrm{C}$-signature of leaves sampled in mid-summer in the upper sun canopy of ten (2005: seven) mature beech stands along a precipitation gradient in central Germany (mean of 180 and 30 sun leaves randomly collected with a crossbow from three and two tree individuals per site in 2005 and 2006, respectively; $n=$ six and eight for $\delta^{13} \mathrm{C}$, respectively). Values given are data for the years 2005 and 2006 (leaf size 2005: $y=28.0-0.01 x$, $r^{2}=0.68, p=0.01 ; 2006: y=21.5-0.01 x, r^{2}=0.21, p=0.09 ; \delta^{13} C$-signature 2005: $y=-27.1-0.002 x, r^{2}=0.45$, $p=0.07 ; 2006$ : $y=25.9-0.003 x, r^{2}=0.33, p=0.04$; data for 2006 according to Fritz, unpubl.). 
Table 3. Statistical characteristics of leaf size distribution in 2003 and 2004 in the 14 beech stands along a precipitation gradient in central Germany (mean, median, standard deviation, minimum, and maximum, skewness and kurtosis of the leaf populations collected in litter buckets; $n=500$ randomly collected leaves per stand). .i. $=$ not investigated. Mean, median, minimum and maximum in $\mathrm{cm}^{2}$.

\begin{tabular}{|c|c|c|c|c|c|c|c|c|c|}
\hline Year & $\begin{array}{c}\text { Site } \\
\#\end{array}$ & $\begin{array}{c}\text { Annual } \\
\text { rainfall } \\
{\left[\mathrm{mm} \mathrm{yr}^{-1}\right]}\end{array}$ & Mean & Median & Min. & Max. & $\begin{array}{l}\text { Std. } \\
\text { dev. }\end{array}$ & Skewness & Kurtosis \\
\hline \multirow[t]{14}{*}{2003} & 1 & 970 & 15.8 & 15.3 & 1.8 & 43.0 & 7.6 & 0.44 & -0.11 \\
\hline & 2 & 950 & 17.1 & 16.6 & 1.5 & 45.8 & 7.2 & 0.51 & 0.42 \\
\hline & 3 & 910 & 18.3 & 17.7 & 2.6 & 46.2 & 7.9 & 0.36 & -0.18 \\
\hline & 4 & 860 & 19.4 & 18.6 & 1.0 & 57.6 & 8.7 & 0.52 & 0.26 \\
\hline & 5 & 820 & 19.3 & 19.0 & 2.2 & 48.8 & 8.3 & 0.41 & 0.19 \\
\hline & 6 & 800 & 17.5 & 17.0 & 1.6 & 39.1 & 7.5 & 0.22 & -0.28 \\
\hline & 7 & 680 & 20.1 & 19.2 & 2.2 & 47.0 & 8.2 & 0.39 & -0.20 \\
\hline & 8 & 670 & 22.4 & 21.3 & 2.0 & 60.7 & 10.7 & 0.84 & 0.96 \\
\hline & 9 & 650 & 22.9 & 22.6 & 3.3 & 49.2 & 9.1 & 0.26 & -0.23 \\
\hline & 10 & 580 & 23.5 & 22.5 & 2.4 & 59.1 & 9.9 & 0.54 & 0.49 \\
\hline & 11 & 580 & 20.9 & 19.8 & 2.9 & 65.6 & 9.5 & 0.94 & 1.86 \\
\hline & 12 & 550 & 23.5 & 23.2 & 2.3 & 48.4 & 8.8 & 0.09 & -0.36 \\
\hline & 13 & 550 & 23.2 & 22.7 & 1.9 & 62.4 & 9.9 & 0.44 & 0.15 \\
\hline & 14 & 520 & 23.4 & 22.5 & 2.5 & 65.1 & 10.2 & 0.54 & 0.49 \\
\hline \multirow[t]{14}{*}{2004} & 1 & 970 & 11.0 & 10.5 & 1.2 & 35.2 & 4.8 & 0.88 & 1.66 \\
\hline & 2 & 950 & 11.2 & 11.1 & 1.7 & 34.0 & 4.2 & 0.97 & 3.43 \\
\hline & 3 & 910 & 12.6 & 11.7 & 1.0 & 35.3 & 5.7 & 0.80 & 0.89 \\
\hline & 4 & 860 & 15.8 & 14.9 & 0.8 & 38.9 & 6.6 & 0.71 & 0.61 \\
\hline & 5 & 820 & 12.7 & 11.9 & 0.4 & 46.1 & 5.9 & 1.33 & 3.98 \\
\hline & 6 & 800 & 10.2 & 9.3 & 0.2 & 33.8 & 5.5 & 1.07 & 1.54 \\
\hline & 7 & 680 & 15.0 & 13.6 & 1.2 & 49.6 & 7.3 & 1.09 & 2.05 \\
\hline & 8 & 670 & 19.3 & 17.6 & 0.9 & 63.1 & 8.9 & 0.98 & 1.62 \\
\hline & 9 & 650 & 16.2 & 15.2 & 1.2 & 44.5 & 7.0 & 0.81 & 1.09 \\
\hline & 10 & 580 & 18.6 & 16.9 & 1.1 & 62.2 & 9.4 & 1.07 & 2.03 \\
\hline & 11 & 580 & 16.2 & 14.8 & 0.9 & 50.5 & 8.1 & 0.90 & 1.03 \\
\hline & 12 & 550 & 17.9 & 16.1 & 2.1 & 53.0 & 7.7 & 1.06 & 1.63 \\
\hline & 13 & 550 & n.i. & & & & & & \\
\hline & 14 & 520 & 15.9 & 14.8 & 0.9 & 58.0 & 8.3 & 1.12 & 2.15 \\
\hline
\end{tabular}

Beech trees growing with less than $550 \mathrm{~mm} \mathrm{yr}^{-1}$ had, on average, 35-45\% larger leaves

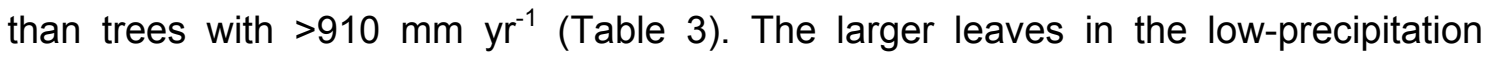
stands had a significantly higher mean specific leaf area (SLA) than the leaves in the moister stands (Table 2). Thus, the drier the climate, the larger and thinner the leaves 

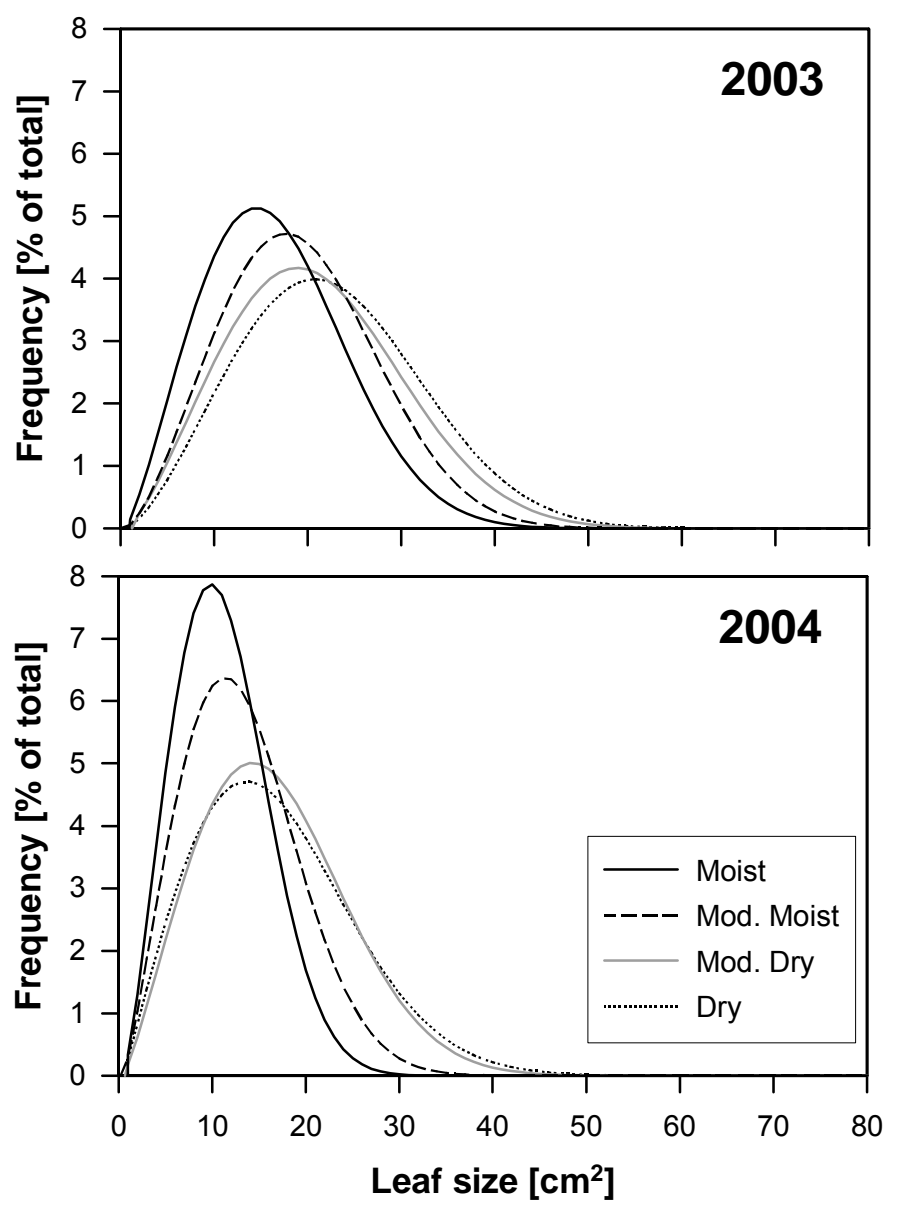

Figure 4. Size distribution in leaf populations $(n=500$ leaves per site) collected by random immediately after leaf fall in 2003 and 2004 in litter buckets (width of leaf size classes: $1 \mathrm{~cm}^{2}$ ). Mean distribution curves for moist (annual precipitation $>900 \mathrm{~mm} \mathrm{yr}^{-1}$ ), moderately moist $(900-750 \mathrm{~mm}$ ), moderately dry (750$600 \mathrm{~mm})$, and dry stands $(<600 \mathrm{~mm})$ are shown. Weibull functions were used to fit the curves.

were. Leaf size and SLA showed a similar dependence on precipitation in the dry summer 2003 and in the wet summer 2004, even though the absolute values of leaf size and SLA were different between the years. As expected, average leaf size was higher in the litter buckets, which contained the whole leaf population, than in the corresponding sun-canopy samples. The leaf populations in the litter fall samples showed not only an increase in arithmetic mean and median values from the moist to the dry end of the gradient, but were also more right-skewed in their distribution with larger leaf size maxima and an overall increase in leaf size variability toward the drier stands (Table 3, Fig. 4). Moreover, the moister stands, but not the drier stands, showed a large increase in maximum leaf size in the dry summer 2003, which resulted in higher mean and median leaf sizes in the dry than in the wet year (Table 3 ). 


\section{Stand leaf mass and leaf area index}

Stand leaf mass $\left(M_{l}\right.$, which is equivalent to annual leaf production) varied between 265 and $393 \mathrm{~g} \mathrm{~m}^{-2}$ in the 14 stands in the two study years (mean 2003: 340, 2004: $339 \mathrm{~g} \mathrm{~m}^{-2}$ ); most values ranged between 320 and $390 \mathrm{~g} \mathrm{~m}^{-2}$ (Fig. 5a). In 2003, no significant relationship between $M_{1}$ and precipitation existed; in contrast, $M_{1}$ increased with decreasing precipitation in 2004.
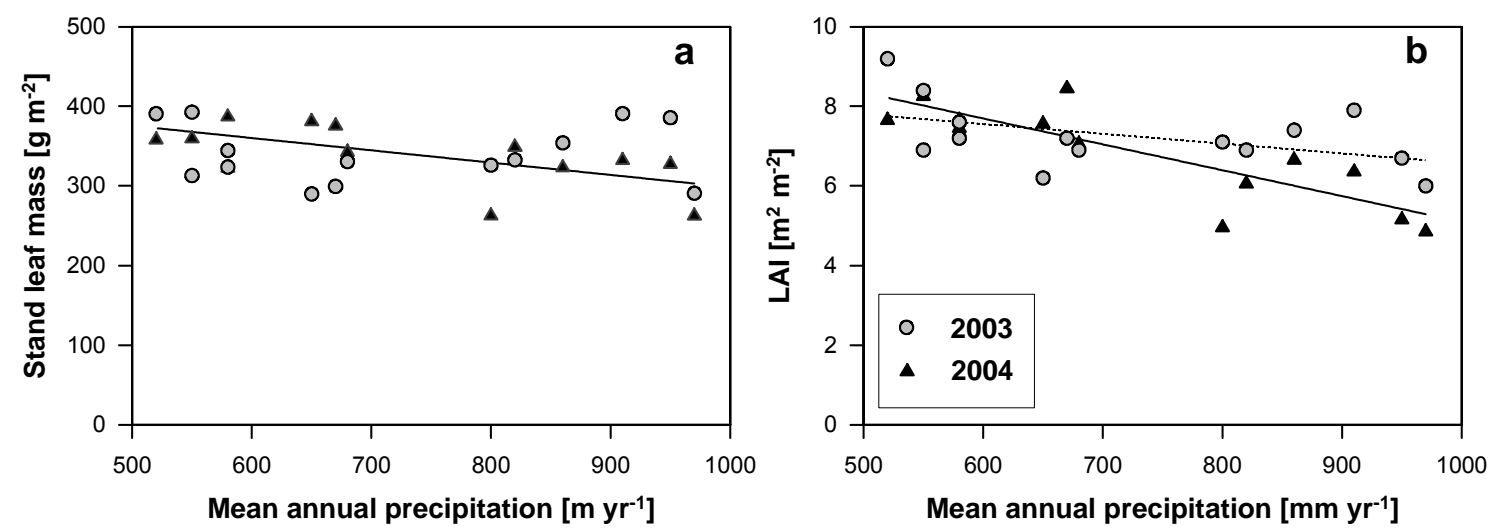

Figure 5a, b. Relationship between mean annual precipitation and stand leaf mass or leaf area index (LAI) in 2003 and 2004 in the 14 beech stands (LAI based on SLA values of 50 randomly selected leaves per bucket multiplied by total leaf dry mass in the buckets; $n=$ ten buckets per site; leaf mass 2003: $r^{2}<0.001$, $p=0.48 ; 2004: y=453-0.2 x, r^{2}=0.39, p=0.01$; LAI 2003: $y=9.0-0.003 x, r^{2}=0.22, p=0.04 ; 2004: y=11.6-0.01 x$, $\left.r^{2}=0.71, p<0.001\right)$.

Leaf area index as derived from the litter fall data showed a significant increase from the high- to the low-precipitation stands in both years (Fig. 5b). LAl ranged between 6.0 and $9.2 \mathrm{~m}^{2} \mathrm{~m}^{-2}$ in 2003 (mean of the 14 stands: 7.2) and between 4.9 and $8.5 \mathrm{~m}^{2} \mathrm{~m}^{-2}$ in

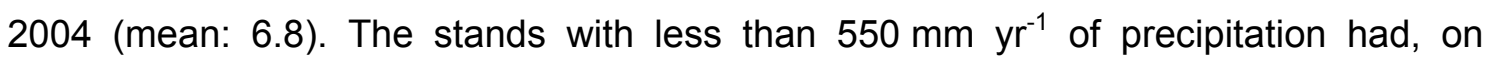
average, a by 19 and 45\% higher leaf area index in the years 2003 and 2004, respectively, than the stands with more than $910 \mathrm{~mm} \mathrm{yr}^{-1}$.

Leaf morphology, leaf area and foliar $\delta^{13} \mathrm{C}$ of leaves as affected by a dry and a wet summer

The dry summer 2003 and the wet summer 2004 contrasted in terms of water supply during the growing season. In agreement with the leaf size trend along the precipitation gradient, mean leaf size was significantly larger in all 14 stands under the lower-thanaverage summer rainfall of 2003 than in 2004 with a $20 \%$-plus rainfall in the study region (Fig. 2a), just as LAI was higher in the dry summer 2003 (mean of the 14 stands: 7.2) than in wet 2004 (6.8), in particular in the eastern low-precipitation section of the transect. The larger leaf area index was mainly a consequence of a 
higher SLA in 2003 compared to 2004, whereas leaf mass was not significantly different between the two hydrologically contrasting years. In fact, stand leaf mass averaged at $340 \mathrm{~g} \mathrm{~m}^{-2}$ in both years, irrespective of precipitation amount.

The $\delta^{13} \mathrm{C}$-signature of sun-canopy leaves increased in both years along the transect from the high- to the low-precipitation stands (Fig. $3 \mathrm{~b}$ ). The ${ }^{13} \mathrm{C} /{ }^{12} \mathrm{C}$ ratio ranged between $-29.6 \%$ and $-28.1 \%$ in 2005 and between $-29.4 \%$ and $-26.7 \%$ in 2006. Beech trees growing with less than $550 \mathrm{~mm} \mathrm{yr}^{-1}$ of precipitation had, on average, a by $1.0 \%$ and by $1.3 \%$ less negative $\delta^{13} \mathrm{C}$-signature of their leaves in the years 2005 and 2006 , respectively, than those growing with more than $850 \mathrm{~mm} \mathrm{yr}^{-1}$.

\section{Leaf area and leaf morphology as influenced by environment and stand structure}

In the transect of 14 stands, precipitation was not the only variable that could have influenced leaf area and leaf morphology of beech. According to a principal components analysis, four additional ancillary gradients (mean annual temperature, stand age, stem density, and topsoil C/N ratio) existed (Fig. 6).

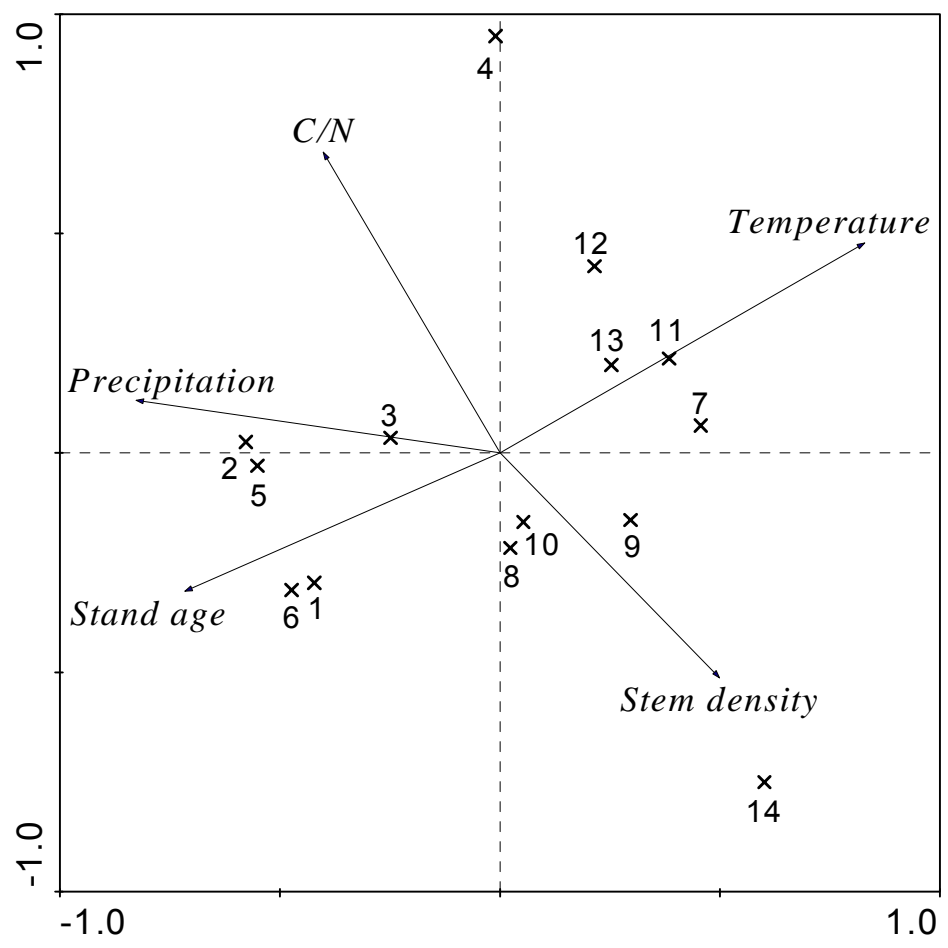

Figure 6. Principal components analysis (PCA) of important environmental and stand structural parameters (mean annual precipitation, mean annual temperature, stand age, stem density, and $\mathrm{C} / \mathrm{N}$ ratio in the mineral topsoil $(0-10 \mathrm{~cm})$ ) in the 14 mature beech stands (eigenvalue of the first axis 0.462 , loading of precipitation -0.810 and of temperature 0.805 ; eigenvalue of the second axis 0.213 , loading of $\mathrm{C} / \mathrm{N}$ ratio 0.657). Numbers indicate the 14 beech stands. 
On the first PCA axis, precipitation and stand age opposed to temperature. Accordingly, precipitation and stand age decreased as temperature increased. Precipitation, temperature and stand age explained together nearly $50 \%$ of the environmental and structural variability among the stands. Stem density and soil $\mathrm{C} / \mathrm{N}$ on the second axis explained another $21 \%$ of the variance.

A multiple regression analysis revealed for the dry summer 2003 that leaf size was influenced most strongly by air temperature in May, but also by stem density, soil moisture, stand age (all positively), and soil C/N (negatively; Table 4). In single factor correlation analyses, the influence of stem density or stand age was lacking (Table 5). In wet 2004, leaf size was exclusively a function of temperature in May, while the other factors had no significant effect (Table 4). The total number of leaves per ground area in 2003 was found to be positively influenced only by summer precipitation (May to September of the preceding year 2002); while neither air temperature, soil $\mathrm{C} / \mathrm{N}$, stem density, nor stand age had a significant effect (model: $r^{2}=0.31, p=0.04$; predictor: $F=7.5, p=0.02$ ). In 2004, none of the tested parameters had a significant effect on leaf numbers according to multiple regression analyses. However, in one-factorial correlation analyses, leaf number in 2004 was negatively influenced by base saturation (Table 5).

Table 4. Multiple regression analysis with backward variable elimination on the effects of soil moisture in May 2003 and 2004 (M), air temperature in May 2003 and 2004 (T), C/N ratio in the mineral topsoil (N), stem density (D) or stand age (A) on average leaf size in the 14 beech stands in 2003 and 2004. Values given are the determination coefficient $r^{2}$ and the probability of error $p$ for the model and the $F$-value and probability of error $p$ for the selected predictors. The + or - signs at the predictor variables indicate positive or negative relationships. For units refer to the tables 1 and 2 .

\begin{tabular}{|c|c|c|c|c|c|c|}
\hline \multicolumn{7}{|c|}{ Model } \\
\hline \multicolumn{2}{|l|}{$\mathbf{Y}$} & \multirow{2}{*}{$\frac{r^{2}}{0.77}$} & \multirow{2}{*}{$\frac{\mathbf{p}}{0.02}$} & \multirow{2}{*}{$\begin{array}{c}\text { Predictor } \\
+T\end{array}$} & \multirow{2}{*}{$\frac{\boldsymbol{F}}{10.3}$} & \multirow{2}{*}{$\frac{\mathbf{p}}{0.01}$} \\
\hline Leaf size & 2003 & & & & & \\
\hline & & & & $+D$ & 10.1 & 0.01 \\
\hline & & & & $+\mathrm{M}$ & 10.0 & 0.01 \\
\hline & & & & $+\mathrm{A}$ & 9.1 & 0.01 \\
\hline & & & & $-N$ & 6.0 & 0.04 \\
\hline Leaf size & 2004 & 0.34 & 0.04 & $+\mathrm{T}$ & 5.6 & 0.04 \\
\hline
\end{tabular}


Table 5. Results of correlation analyses between leaf size or number of leaves and each eight different measures of precipitation and temperature for the 14 mature beech forests during the dry year 2003 and the wet year 2004, as well as soil moisture, $\mathrm{N}$ - and P-contents in the mineral soil, stem density, and stand age. Values given are the Pearson correlation coefficient $r$ and the probability of error $p$. Tested were the long-term mean (1), the long-term mean from May to September (2), the annual mean or sum of the study year (3), of the period from May to September of the study year (4), of April/May of the study year (5), of the respective preceding year (2002 or 2003) (6), from May to September of the preceding year (7), and in August of the preceding year (8).

\begin{tabular}{|c|c|c|c|c|c|c|c|c|}
\hline & \multicolumn{4}{|c|}{ Leaf size } & \multicolumn{4}{|c|}{ Number of leaves } \\
\hline & \multicolumn{2}{|c|}{2003} & \multicolumn{2}{|c|}{2004} & \multicolumn{2}{|c|}{2003} & \multicolumn{2}{|c|}{2004} \\
\hline & $\mathbf{r}$ & p & $\mathbf{r}$ & p & $r$ & p & $\mathbf{r}$ & $\mathbf{p}$ \\
\hline Prec 1 & -0.92 & $<0.001$ & -0.77 & 0.001 & 0.55 & 0.02 & 0.08 & 0.40 \\
\hline Prec 2 & -0.94 & $<0.001$ & -0.84 & $<0.001$ & 0.62 & 0.01 & 0.05 & 0.43 \\
\hline Prec 3 & -0.84 & $<0.001$ & -0.67 & 0.01 & 0.45 & 0.05 & -0.06 & 0.42 \\
\hline Prec 4 & -0.44 & 0.06 & -0.73 & 0.003 & 0.03 & 0.45 & -0.06 & 0.42 \\
\hline Prec 5 & -0.41 & 0.07 & -0.26 & 0.20 & 0.23 & 0.22 & -0.04 & 0.44 \\
\hline Prec 6 & -0.85 & $<0.001$ & -0.64 & 0.01 & 0.47 & 0.04 & 0.05 & 0.44 \\
\hline Prec 7 & -0.87 & $<0.001$ & -0.38 & 0.10 & 0.56 & 0.02 & -0.13 & 0.33 \\
\hline Prec 8 & -0.48 & 0.04 & -0.29 & 0.17 & 0.37 & 0.09 & -0.31 & 0.15 \\
\hline Moist 5 & 0.24 & 0.21 & 0.41 & 0.08 & -0.41 & 0.07 & -0.08 & 0.40 \\
\hline Temp 1 & 0.67 & 0.004 & 0.72 & 0.003 & -0.33 & 0.13 & 0.12 & 0.35 \\
\hline Temp 2 & 0.66 & 0.005 & 0.71 & 0.004 & -0.34 & 0.12 & 0.10 & 0.37 \\
\hline Temp 3 & 0.66 & 0.005 & 0.69 & 0.004 & -0.32 & 0.13 & 0.12 & 0.35 \\
\hline Temp 4 & 0.66 & 0.005 & 0.71 & 0.003 & -0.32 & 0.13 & 0.11 & 0.36 \\
\hline Temp 5 & 0.67 & 0.005 & 0.71 & 0.003 & -0.30 & 0.15 & 0.11 & 0.36 \\
\hline Temp 6 & 0.64 & 0.006 & 0.71 & 0.003 & -0.29 & 0.15 & 0.13 & 0.33 \\
\hline Temp 7 & 0.67 & 0.004 & 0.71 & 0.003 & -0.31 & 0.14 & 0.11 & 0.36 \\
\hline Temp 8 & 0.67 & 0.004 & 0.70 & 0.004 & -0.30 & 0.15 & 0.12 & 0.34 \\
\hline $\mathbf{N}$ & -0.42 & 0.07 & -0.42 & 0.08 & 0.20 & 0.25 & 0.07 & 0.41 \\
\hline $\mathrm{C} / \mathrm{N}$ & -0.24 & 0.20 & -0.09 & 0.39 & 0.24 & 0.21 & -0.05 & 0.44 \\
\hline $\mathbf{P}_{\mathbf{a}}$ & 0.16 & 0.30 & -0.19 & 0.27 & -0.15 & 0.31 & -0.34 & 0.13 \\
\hline$C / P_{a}$ & -0.14 & 0.32 & 0.22 & 0.24 & 0.13 & 0.33 & 0.29 & 0.17 \\
\hline $\mathrm{N} / \mathrm{P}_{\mathrm{a}}$ & -0.11 & 0.35 & 0.20 & 0.25 & 0.08 & 0.39 & 0.37 & 0.11 \\
\hline Base saturation & 0.38 & 0.09 & -0.33 & 0.12 & 0.44 & 0.07 & -0.59 & 0.02 \\
\hline Stem density & 0.35 & 0.11 & 0.33 & 0.14 & 0.04 & 0.45 & 0.14 & 0.32 \\
\hline Stand age & -0.25 & 0.19 & -0.39 & 0.09 & 0.21 & 0.24 & -0.16 & 0.30 \\
\hline
\end{tabular}




\section{Discussion}

\section{The leaf area-water supply relationship in forests}

Two different approaches have been used in tree physiology to analyse the relationship between water availability and leaf area in woody plants: (i) experimental studies in the laboratory or in gardens with potted seedlings or saplings, and (ii) comparative field studies along natural rainfall gradients. Precipitation has often been used as a proxy of soil water availability, because continuous soil moisture data are mostly lacking as in the present study. In this study, a close correlation between rainfall amount and soil moisture existed, in particular in the mid- to late-summer period, which justifies this approach (Fig. 1b). A reduction of leaf area in drought-exposed plants can occur as a short-term response to unusual stress events or in the course of a long-term adjustment to growth-limiting water regimes. Both processes are physiologically different. In the first case, part or all of the leaves are abscised during the growing season prior to normal leaf senescence (Torrecillas et al. 1999, Munné-Bosch \& Alegre 2004, Bréda et al. 2006); in the second case, the number of new leaf buds or the rate of leaf expansion, or both, are reduced (Fotelli et al. 2000, Otieno et al. 2005). The relationship between water availability (alternatively precipitation) and leaf area development may be different in the two cases.

Growth experiments with tree seedlings or saplings under contrasting soil moisture treatments may typically comprise both short-term responses to drought stress and long-term acclimation processes, because the plants most often are only partly adapted to the specific drought regime of the experiment. In contrast, field studies comparing different forest stands in contrasting environments most often reflect primarily long-term (phenotypic and genotypic) adjustments to the existing water regime, while short-term responses to extreme drought stress events are of secondary importance. Not surprisingly, the two approaches may yield different results on the leaf area-water supply relationship.

Drought experiments with potted tree seedlings or saplings in most cases showed a reduction in average leaf size, specific leaf area, and total leaf area per plant with increasing water shortage; this response is to be expected from basic physiological knowledge (Kozlowski \& Pallardy 1997, Otieno et al. 2005). However, in a few cases, contrary results were also obtained in experiments with tree seedlings. For example, Aspelmeier \& Leuschner (2006) reported a larger mean leaf size and a higher SLA (but a reduced total leaf area) in desiccated birch saplings compared to the well watered control plants. They explained their unexpected finding by a drought-induced leaf shedding of older leaves and a subsequent carbon and nitrogen allocation shift to the 
recently produced leaves that were partly released from drought stress limitation after several leaves had been shed.

The large majority of studies in mature stands reported a positive relationship between precipitation or soil water availability and leaf area index, when moisture transects included a turnover of tree species or forest communities (e.g., Grier \& Running 1977, Kozlowski \& Pallardy 1997, Bussotti et al. 2000, Eamus 2003, Prior et al. 2005). In studies with only one tree species, a reduction in LAI with decreasing rainfall was found in certain temperate coniferous stands by Gower et al. (1992), Mencuccini \& Grace (1994), Hebert \& Jack (1998) and Maherali \& DeLucia (1998), and in species-poor tropical forests (Hawaii) by Harrington et al. (1995), Austin \& Vitousek (1998) and Ares \& Fownes (1999). However, we are only aware of one study (Bussotti et al. 2000) along a rainfall gradient focussing on the LAI of a temperate broad-leaved tree species. In the present study, both average leaf size and LAI increased with a decrease in precipitation, independently of the method applied for leaf area determination (litter sampling or mid-summer leaf harvesting). This result contradicts our working hypothesis and also contrasts with the above-mentioned literature data from temperate coniferous and tropical island forests with a positive leaf area-water supply relationship.

\section{Environmental controls of forest leaf area}

The unexpected increase in LAI toward the drier end of our precipitation gradient was the consequence of a significant increase in average leaf size, which more than compensated for a reduced total number of leaves in the drier stands. According to the frequency distribution diagrams in figure 4, the number of large leaves increased in dry years and towards drier stands. For analysing the factors that may control leaf size and total leaf numbers, we applied single factor and multiple correlation analyses. Surprisingly, not only mean annual precipitation was negatively correlated with leaf size and LAI (compare figs. 2a, 3a, and 5), but also other components of precipitation such as the long-term mean precipitation in the period May to September or in April/May of the study year, and even the precipitation of the preceding year (Table 5). This unexpected result demands a closer look on other factors such as temperature and soil nitrogen, which tend to increase with decreasing precipitation and might have direct and/or indirect effects on leaf size and LAI. In fact, mean annual precipitation was negatively correlated with mean air temperature in our sample $\left(r^{2}=0.41, p=0.01\right)$ and tended to increase with $\mathrm{C} / \mathrm{N}$ ratio $\left(r^{2}=0.12, p=0.12\right)$. 
The process of leaf expansion is partly controlled by genetic constitution (adaptation), partly by the environmental conditions during leaf flushing, i.e., by phenotypic plasticity (Parkhurst \& Loucks 1972, Van Volkenburgh 1999, Hovenden \& Vander Schoor 2004, Aspelmeier \& Leuschner 2006). Besides water availability, nitrogen supply, radiation and temperature are environmental factors that are known to influence leaf expansion (Milthorpe \& Newton 1963, Radin \& Boyer 1982, Tardieu et al. 1999, Harrington et al. 2001). While the radiation regime during leaf flushing is crucial for developing the sun leaf/shade leaf dichotomy within the crown (Kim et al. 2005), it is probably of no relevance for differences in average leaf sizes among the 14 studied stands, because radiation input was more or less uniform along the transect (mean sum of global radiation in two measuring years: 2420 and $2330 \mathrm{MJ} \mathrm{m}^{-2}$ in the moistest and the driest beech stand of the transect, respectively; Schipka 2003). From a look on the frequency distribution graphs of leaf size it appears that stands in a drier climate or in a drier summer produced more extreme shade leaves with very large size (Fig. 4), while the total number of leaves per ground area and the number of small sun-canopy leaves decreased from the moist to the dry stands, at least in the dry summer of 2003 . This indicates a more open sun canopy in drier climates or drier summers that transmits more radiation to the lower leaf strata (Sack et al. 2006). In other words, in moist climates or moist summers, leaf size in the beech shade canopy seems to be stronger limited by low light, since the sun canopy is more closed under those conditions. Any factor that reduces the density of the sun canopy would then promote leaf expansion in the shade canopy, leading to particularly large shade leaves.

Our data indicate that other factors than a higher radiation transmission through the sun canopy must also play a role in explaining the leaf size increase toward the dry end of the transect. Leaf sampling in July/August in the upper sun canopy of the stands revealed a similar increase in average leaf size towards drier sites (Fig. 3a) as did the litter fall data, which represented the whole leaf population of the trees. Thus, not only the shade leaves, but also the sun leaves, increased in mean size. In the multiple regression analyses, we therefore focussed on the influence of those environmental variables that could influence leaf flushing in May, i.e., air temperature in May, soil moisture in May and soil $\mathrm{C} / \mathrm{N}$ ratio, as well as stem density and stand age. Obviously, in both years, the largest influence on leaf area was exerted by air temperature, followed by soil moisture and stem density in 2003. In 2004, air temperature in May was the single influential factor. This indicates that leaf expansion was stimulated by higher spring temperatures.

Because cell expansion has been found to be highly sensitive to plant water deficits (Bradford \& Hsiao 1982, Lu \& Neumann 1998, Bray 2004), we assumed that soil water 
status during April and May is the most influential abiotic factor controlling leaf size of beech. However, our soil moisture measurements on all study plots in May 2004 showed ample soil water reserves (16 to 24 vol. $\%$ ) in this period in all stands, indicating that drought stress cannot be a major factor in this critical period of leaf development (cf. Dittmar \& Elling 2006), neither in the moist nor in the dry sections of the transect. In fact, all stands received sufficient rainfall in the months before May 2003 and May 2004 to reach field capacity of soil water when leaf flushing started. Favourable soil moisture conditions in May existed irrespective of rainfall deficits that may have developed later in the summer of the respective year.

The absence of an effect of water availability in May on leaf expansion would explain why beech leaves are equally large, or even larger, in stands with low summer rainfall as in the eastern section of the transect. In fact, a negative gradient in soil moisture from the western to the eastern end of the transect does not develop before July (Fig. 1a and Schipka et al. 2005). Leaf size development and summer droughts, as they develop later in the year, seem to be seasonally decoupled in temperate tree species such as beech (cf. Hanson \& Weltzin 2000, Wullschleger \& Hanson 2006). Nevertheless, late-summer droughts can have a dramatic effect on tree physiological processes other than leaf expansion (Gebre et al. 1998, Tschaplinski et al. 1998, Wullschleger et al. 1998, Wullschleger \& Hanson 2006).

Our hydrological observations match well the results of the regression analyses. They imply that a higher temperature in spring seems to be an important factor promoting a larger leaf size and LAI in beech (significant), whereas the influence of water supply is relatively small (Table 4 and 5). The observation of Nihlgård \& Lindgren (1977), who found a particularly low LAI (2.9-4.3 $\left.\mathrm{m}^{2} \mathrm{~m}^{-2}\right)$ at the northern limit of beech distribution in southern Sweden, may be viewed as support of this conclusion. Along altitudinal gradients in mountains that comprise an increase of water availability and a decrease of temperature, leaf area seems to be largely under the control of temperature (Körner et al. 1986).

A better $\mathrm{N}$-supply could also be one of the causes of larger leaves and a higher LAI in the stands of the drier end of our transect (Table 4 and 5), as indicated by a weakly significant correlation with the total nitrogen pool. Soil chemical analyses evidenced not only a decrease of the $\mathrm{C} / \mathrm{N}$ ratio by $3 \mathrm{~mol} \mathrm{~mol}^{-1}$ with decreasing rainfall, but also indicated a tendency towards a higher base saturation in the mineral topsoil (difference not significant; Meier \& Leuschner, unpublished). Since all stands grow on the same geological substrate, this gradient in soil chemistry is thought to be caused by an increasing summer deficit in the climatic water balance toward the drier end of the transect, which reduces the leaching loss of nitrate and base cations (Yavitt \& Wright 
1996). Even though $\mathrm{N}$-mineralisation data are missing, a better $\mathrm{N}$-supply in spring during leaf flush at the drier and more base-rich sites is likely from the well documented close correlation between $\mathrm{C} / \mathrm{N}$ ratio, base saturation and $\mathrm{N}$-mineralisation rate and soil fertility or base saturation in temperate forest soils (Kriebitzsch 1989, Singh \& Singh 1994, Van der Krift \& Berendse 2001). Elevated nitrogen supply and uptake by the roots increase the synthesis of cytokinins which enhance leaf expansion (Van der Werf \& Nagel 1996), implying a direct positive effect of soil $\mathrm{N}$-availability on beech leaf area. Thus, relatively mild drought stress, as it develops at 520 to $650 \mathrm{~mm} \mathrm{yr}^{-1}$ of precipitation at the dry end of our transect, should increase N-supply and enhance leaf expansion, thereby compensating for any negative effect of water shortage on beech leaf development. In arid climates with more severe droughts than in central Germany, however, nitrogen mineralisation and $\mathrm{N}$-diffusion to the root surface most likely will be growth-limiting processes. They may reduce leaf expansion, instead of increasing it, leading to smaller, more scleromorphic leaves as an adaptive response to drought.

The number of leaves produced by a beech tree is determined by the number of buds, which were formed during July or August of the preceding summer (Eschrich et al. 1989). Fagus sylvatica expands its leaves in a single leaf flush in May; dormant buds for additional leaf flushes later in summer are lacking in this species. Thus, we expect that the number of leaves is primarily determined by the environmental conditions in the previous year's mid-summer period (July/August), when drought periods are usually most severe in the study region. Reductions in the tree's vitality and growth potential in mid-summer could negatively affect the number of buds produced, which should reduce the number of leaves present in the subsequent year. This produces a hang-over effect of drought stress on beech leaf area, which lasts for at least one year. Our multiple regression analysis with backward variable elimination revealed that the amount of precipitation in the preceding growing season (May to September) was indeed a highly influential variable determining total leaf numbers. However, this variable had a significant effect in 2003 only, but not in 2004. Other abiotic and biotic parameters that were tested such as summer temperature, soil $\mathrm{C} / \mathrm{N}$ ratio, or stand age had no significant influence on total leaf numbers at all.

\section{Leaf area development and the drought sensitivity of beech}

With mean values of 6.8 to $7.2 \mathrm{~m}^{2} \mathrm{~m}^{-2}$, central German beech forests are maintaining a relatively high leaf area index compared to other broad-leaved tree species (Jaro 1959, Leuschner et al. 2006b). Moreover, LAl is not reduced in close proximity to the drought limit of beech existence at the drier end of the studied transect. What is the adaptive significance of a large leaf area and relatively mesomorphic leaves in this species? 
Results obtained from the present study and from other investigations on the water status of mature beech trees allow some conclusions on the whole-tree drought response of Fagus sylvatica and the role played by leaf area in this context. Not surprisingly, there is multiple evidence that water shortage during mid-summer hits the leaves of the low-precipitation stands harder than those in the moister section of the transect. First, the $\delta^{13} \mathrm{C}$-signature of sun leaf dry mass in July was significantly less negative in low than in high rainfall stands, indicating a greater reduction of leaf conductance, or a smaller maximum leaf conductance, at the drier sites (Fig. 3b). A lowered leaf conductance coincided with a reduced photosynthetic activity of beech during severe drought periods as observed in gas exchange measurements in the dry summer 1996 in stand \#14 at the low-rainfall end of the transect (Landwehr, unpublished results). Second, during dry summers, leaves are shed at pre-senescent state in August or September in the drier stands of our transect and in other Central European beech forests on shallow soils (Stefancik 1997, Bréda et al. 2006). We speculate that massive leaf losses are partly the consequence of the apparent decoupling of leaf area development in wet May and the severe summer droughts later in the year in July/August; the latter seem to hit a leaf area that is not well adapted to this kind of stress. Third, a poor match between leaf area and the severity of summer droughts may also be the cause of late-summer reductions in stem growth, which are characteristic for beech not only in dry, but also in relatively wet climates (Pigott \& Pigott 1993, Lebaube et al. 2000). Finally, on shallow soils, beech may suffer from periodic canopy dieback leading to elevated tree mortality rates during long dry spells (pers. observation).

Given these obvious physiological limitations, it is surprising that beech is maintaining a high LAl even in the driest environments that are tolerated by this species. This behaviour reflects the conflicting demands of competitive and stress tolerating strategies on plant physiology and morphology. A high leaf area index is the basis not only of a relatively high carbon gain, but also of the species' ability to cast deep shade, which successfully suppresses competitors for light or soil resources (Ellenberg 1996). The large leaf area and its maintenance under variable environmental conditions play a key role in the survival strategy of this late-successional species. A determinate mode of leaf expansion early in the summer and the risk of physiological failure later in summer must be seen as unavoidable trade-offs of the strategy of beech to reach competitive superiority in a large variety of environments. For disentangling the full complexity of the environmental and biotic controls of leaf area development in beech, manipulative studies in controlled environments combined with field observations in mature stands are needed. 


\section{Acknowledgement}

The authors would like to thank Dr. H. Meesenburg (Nordwestdeutsche Forstliche Versuchsanstalt, Göttingen), Dr. D. Burk, and R. Fritz for the provision of data. We gratefully acknowledge financial support granted to I.C. Meier by the Deutsche Bundesstiftung Umwelt. 


\title{
Chapter 4
}

The belowground drought response of European beech:

fine root biomass and carbon partitioning in 14 mature stands across a precipitation gradient

\author{
IC Meier $\cdot$ Ch Leuschner
}

Global Change Biology (2008, accepted) 


\section{Abstract}

How tree root systems will respond to increased drought stress, as predicted for parts of Central Europe, is not well understood. According to the optimal partitioning theory, plants should enhance root growth relative to aboveground growth in order to reduce water limitations. We tested this prediction in a transect study with 14 mature forest stands of European beech (Fagus sylvatica L.) by analyzing the response of the fine root system to a large decrease in annual precipitation (970 to $520 \mathrm{~mm} \mathrm{yr}^{-1}$ ). In three years with contrasting precipitation regimes, we investigated leaf area and leaf biomass, fine root biomass and necromass (organic layer and mineral soil to $40 \mathrm{~cm}$ ), and fine root productivity (ingrowth core approach), and analysed the dependence on precipitation, temperature, soil nutrient availability, and stand structure. In contrast to the optimal partitioning theory, fine root biomass decreased by about a third from stands with $>950 \mathrm{~mm} \mathrm{yr}^{-1}$ to those with $<550 \mathrm{~mm} \mathrm{yr}^{-1}$ while leaf biomass remained constant, resulting in a significant decrease, and not an increase, of the fine root/leaf biomass ratio towards drier sites. Average fine root diameter decreased toward the drier stands, thereby partly compensating for the loss in root biomass and surface area. Both $\delta^{13} \mathrm{C}$-signature of fine root mass and the ingrowth core data indicated a higher fine root turnover in the drier stands. PCA and regression analyses revealed a positive influence of precipitation on the profile total of fine root biomass in the 14 stands, and a negative one of temperature and plant-available soil phosphorus. We hypothesize that summer droughts lead to increased fine root mortality, thereby reducing root biomass, but they also stimulate compensatory fine root production in the drier stands. We conclude that the optimal partitioning theory fails to explain the observed decrease in the fine root/leaf biomass ratio, but is supported by the data if carbon allocation to roots is considered, which would account for enhanced root turnover in drier environments.

Keywords: $\delta^{13} \mathrm{C}$-signature, Fagus sylvatica, fine root necromass, root carbon turnover, ingrowth cores, optimal partitioning theory, phosphorus, root morphology, soil moisture, temperature 


\section{Introduction}

Global warming will most likely increase the frequency and duration of summer droughts in various regions of Central Europe (Rowell \& Jones 2006, IPCC 2007). Periodic soil water shortage together with a higher atmospheric demand for water vapour could reduce the growth and vitality of sensitive tree species with the possible consequence of drought-induced dieback in parts of the distribution range. Forest dieback as a consequence of global warming and higher drought intensities has recently been reported, for example, from the south Argentinean Andes and from Southern Europe, where Nothofagus pumilio (Poepp. \& Endl.) Krasser and Fagus sylvatica L., respectively, are retreating from their drought-induced forest lines (Peñuelas \& Boada 2003, Masiokas \& Villalba 2004). In Central Europe, Fagus sylvatica L. and Picea abies (L.) Karst. are economically important tree species with a suboceanic or boreal distribution range, which may be sensitive to increasing water shortage in summer.

Even though Fagus sylvatica achieves dominance on sites representing a relatively broad spectrum of hydrological regimes, this species has been found to be more sensitive to drought-induced xylem embolism and stem growth reductions than other temperate broad-leaved trees such as oaks (Magnani \& Borghetti 1995, Cochard et al. 2001, Leuschner et al. 2001a). In addition, European beech may suffer from presenescent leaf shedding or even canopy dieback on shallow soils when facing severe drought (Bréda et al. 2006). Further, Fotelli et al. (2004) and Geßler et al. (2005) have postulated that Fagus sylvatica may suffer from drought-induced nitrogen shortage, which could reduce growth and vitality under a future drier climate.

While much attention has been paid to the drought response of aboveground organs such as stems, twigs and leaves, little is known about the response of the root system of mature beech trees to water shortage. Fine roots, i.e., roots $<2 \mathrm{~mm}$ in diameter, represent a small but functionally highly important fraction of tree biomass, which might respond more sensitively to drought than aboveground organs. Although fine roots constitute only about $2-3 \%$ of the total biomass, fine root production may account for roughly $50 \%$ of the carbon cycled in forests, and can consume up to $66 \%$ of the annual photosynthate assimilated by the canopy (Nadelhoffer \& Raich 1992, Hendrick \& Pregitzer 1993, Vogt et al. 1996). Any distortion of the fine root system by stressors such as drought should therefore not only influence tree vitality, but might also affect carbon and nutrient cycling in the ecosystem.

Besides temperature, nutrient availability and some other biotic and abiotic parameters, soil moisture is a key factor that has been found to influence fine root biomass and 
turnover of trees (Kuhns et al. 1985, Santantonio \& Hermann 1985, Nisbeth \& Mullins 1986, Pregitzer et al. 1993, Espeleta et al. 1999, Gill \& Jackson 2000, Leuschner \& Hertel 2003). According to the optimal partitioning theory, plants should allocate relatively more carbon and nutrients to root growth than to aboveground growth, when plant growth is limited by water and/or nutrient shortage (Bloom et al. 1985). However, evidence in support of this theory, when applied to tree root growth during water shortage, is partly contradictory and should be scale-dependent. Not only irrigation (e.g., Alexander \& Fairley 1983, Khalil \& Grace 1992, Fort et al. 1997) but also experimental drought (e.g., Bongarten \& Teskey 1987, Van Hees 1997, Kozlowski \& Pallardy 2002) has been found to stimulate fine root growth of tree seedlings or saplings in greenhouse or garden experiments, indicating that the response of the root system depends on drought intensity and duration. However, laboratory experiments with tree seedlings or saplings may not give adequate information for predicting the drought response of adult trees in the field. Field manipulation of the hydrology of forests such as throughfall exclusion experiments will yield more realistic results (e.g., Joslin et al. 2000, Davidson et al. 2004, Borken et al. 2006), but often lack sufficient site replication and exclude long-term adaptive responses of the tree root system due to relatively short experimental duration.

If carefully selected with respect to the comparability of study sites, comparative studies along precipitation or soil moisture gradients can produce valuable information on the long-term adaptive response of tree fine root systems to water shortage. Major advantages of transect studies along hydrological gradients are (i) the possibility to investigate a relatively large number of stands allowing for statistical analysis, and (ii) the fact that mature stands are studied in which the trees should have adapted to the local drought regime.

The few studies that examined the root system of a single tree species along precipitation gradients showed decreases in fine root biomass with decreasing rainfall (Nisbeth \& Mullins 1986, Leuschner \& Hertel 2003, Leuschner et al. 2004). Increasing water shortage was found to inhibit fine root production in temperate forests (Teskey \& Hinckley 1981, Kuhns et al. 1985, Burton et al. 2000, Joslin et al. 2000). However, stimulation of tree fine root growth by drought has also been reported from mature forests (e.g., Santantonio \& Hermann 1985, Leuschner et al. 2001a). Unfortunately, most data sets refer to one or two stands only. This makes conclusions on the more general relationship between tree root system size or activity and water availability difficult.

This study investigates stand fine root biomass, fine root morphology and fine root productivity in 14 mature stands of European beech along a steep precipitation 
gradient (970 to $520 \mathrm{~mm} \mathrm{yr}^{-1}$ ). The aim of the study was to detect adaptive responses of the fine root system of beech to a decrease in water availability. By relating profile totals of fine root biomass, the fine root/leaf biomass ratio, as well as ingrowth core measurements and the $\delta^{13} \mathrm{C}$ signature of fine root mass (as indicators of carbon allocation) to precipitation, we tested the optimal partitioning theory in mature forests. This theory predicts that relatively more carbon should be allocated to root growth than to leaf growth with decreasing water availability, which could result either in a larger fine root biomass to foliar biomass ratio, or a higher fine root turnover, or both.

\section{Materials and Methods}

\section{Study area and forest stands}

Fourteen mature beech forests with comparable stand structure were selected for study in the centre of the distribution range of Fagus sylvatica in central Germany (Table 1). The sites were chosen along a $150 \mathrm{~km}$ long WNW-ESE transect in submontane elevation between the Solling Mountains and the Thuringian Basin. Stand selection criteria were (i) closed canopy without major gaps, (ii) even-aged stand structure (100 to $140 \mathrm{yrs}$ old; extremes: 90 and $157 \mathrm{yrs}$ ), (iii) no significant presence of other tree species, and (iv) similar stem densities (175-250 $\left.\mathrm{n} \mathrm{ha}{ }^{-1}\right)$. The root and soil chemical sampling took place in a $30 \times 30 \mathrm{~m}$ plot in the centre of each stand. Typically, beech formed a single closed canopy layer (mono-layer) with additional tree layers and shrubs being mostly absent. Forest management activities in the stands had not been conducted for at least seven yrs, in most cases for more than ten yrs prior to study. All stands grew on the same geological substrate (Triassic sandstone of Middle Bunter, 'Hardegsen Folge') to ensure sufficient comparability of soil chemical conditions. The sites were not affected by compensatory liming activities of forestry except for stand \#6 (eight yrs ago) and \#3 (13 yrs ago). The soils ranged from acidified Cambisols to podzolic Umbrisols, the humus form from vermimulls to leptomoders. On average, a $5.3 \mathrm{~cm}$ thick organic matter layer on top of the soil was present in the 14 stands (extremes: $3.5-7.2 \mathrm{~cm}$ ). The rather nutrient-poor soils had a $\mathrm{C} / \mathrm{N}$ ratio of 17 $26 \mathrm{~mol} \mathrm{~mol}^{-1}$ (mean: 21) and a plant-available phosphorus content of $0.2-1.7 \mathrm{~mol} \mathrm{~m}^{-2}$ $20 \mathrm{~cm}^{-1}$ (mean: 0.8).

Mean annual temperature was $7.8^{\circ} \mathrm{C}$ with a tendency for slightly higher temperatures in the eastern, more continental section of the gradient. Mean annual precipitation

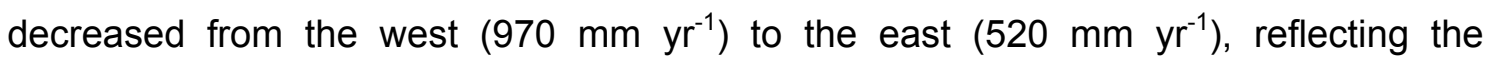
transition from a more sub-oceanic to a more sub-continental climate in the rain shadow of the Solling and Harz mountains. The corresponding summer rainfall (May to September) decreased from 420 to $270 \mathrm{~mm} \mathrm{yr}^{-1}$. 


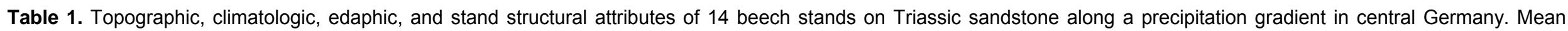
annual precipitation and temperature were derived from weather station data corrected for altitude.

\begin{tabular}{|c|c|c|c|c|c|c|c|c|c|c|c|c|}
\hline \multirow{2}{*}{$\begin{array}{l}\text { Site } \\
\# \\
1\end{array}$} & \multicolumn{2}{|c|}{ Coordinates } & \multirow{2}{*}{$\begin{array}{c}\begin{array}{c}\text { Altitude } \\
\text { [m a.s.I.] }\end{array} \\
400\end{array}$} & \multirow{2}{*}{$\begin{array}{c}\text { Exposition } \\
\text { NW }\end{array}$} & \multirow{2}{*}{$\begin{array}{c}\begin{array}{c}\text { Inclination } \\
{\left[{ }^{\circ}\right]}\end{array} \\
9\end{array}$} & \multirow{2}{*}{$\begin{array}{c}\begin{array}{c}\text { Precipitation } \\
{\left[\mathrm{mm} \mathrm{yr}^{-1}\right]}\end{array} \\
970\end{array}$} & \multirow{2}{*}{$\begin{array}{c}\begin{array}{c}\text { Temperature } \\
{\left[{ }^{\circ} \mathrm{C}\right]}\end{array} \\
7.3\end{array}$} & \multirow{2}{*}{$\begin{array}{c}\begin{array}{c}\text { Stand age } \\
\text { [yr] }\end{array} \\
136\end{array}$} & \multirow{2}{*}{$\begin{array}{c}\begin{array}{c}\text { Stem basal } \\
\text { area }\left[\mathrm{m}^{2} \mathrm{ha}^{-1}\right]\end{array} \\
30.3\end{array}$} & \multirow{2}{*}{$\begin{array}{c}\begin{array}{c}\text { Organic layer } \\
\text { depth [cm] }\end{array} \\
5.5^{\mathrm{a}}\end{array}$} & \multirow{2}{*}{$\frac{\begin{array}{c}\mathrm{C} / \mathrm{N}_{(\min )} \\
{\left[\mathrm{mol} \mathrm{mol}^{-1}\right]}\end{array}}{21.1^{\mathrm{bcde}}}$} & \multirow{2}{*}{$\frac{\begin{array}{c}\mathbf{P}_{\mathrm{a}(\mathrm{min})} \\
{\left[\mathrm{mol} \mathrm{m}^{-2}\right]}\end{array}}{0.95^{\alpha \beta}}$} \\
\hline & $09^{\circ} 36^{\prime}$ & $51^{\circ} 48^{\prime}$ & & & & & & & & & & \\
\hline 2 & $09^{\circ} 40^{\prime}$ & $51^{\circ} 43^{\prime}$ & 380 & NW & 4 & 950 & 7.4 & 153 & 35.0 & $7.2^{a}$ & $23.3^{a b c}$ & $0.50^{\alpha \beta}$ \\
\hline 3 & $09^{\circ} 26^{\prime}$ & $51^{\circ} 44^{\prime}$ & 340 & NW & 4 & 910 & 7.7 & 126 & 32.5 & $4.2^{\mathrm{a}}$ & $20.3^{\text {bcde }}$ & $0.45^{\alpha \beta}$ \\
\hline 4 & $10^{\circ} 02^{\prime}$ & $51^{\circ} 57^{\prime}$ & 250 & SW & 7 & 860 & 8.2 & 99 & 30.6 & $6.8^{a}$ & $25.7^{\mathrm{a}}$ & $0.43^{\alpha \beta}$ \\
\hline 5 & $09^{\circ} 39^{\prime}$ & $51^{\circ} 32^{\prime}$ & 410 & NE & 2 & 820 & 7.3 & 157 & 31.8 & $5.5^{\mathrm{a}}$ & $26.4^{a}$ & $0.32^{\alpha \beta}$ \\
\hline 6 & $09^{\circ} 44^{\prime}$ & $51^{\circ} 19^{\prime}$ & 440 & NW & 7 & 800 & 7.1 & 143 & 30.5 & $4.5^{\mathrm{a}}$ & $19.7^{\text {bcde }}$ & $1.47^{a}$ \\
\hline 7 & $10^{\circ} 01^{\prime}$ & $51^{\circ} 29^{\prime}$ & 250 & $\mathrm{~N}$ & 1 & 680 & 8.2 & 90 & 21.3 & $5.4^{\mathrm{a}}$ & $17.1^{\mathrm{e}}$ & $0.24^{\beta}$ \\
\hline 8 & $10^{\circ} 29^{\prime}$ & $51^{\circ} 23^{\prime}$ & 340 & SW & 10 & 670 & 7.7 & 132 & 27.4 & $5.7^{\mathrm{a}}$ & $20.9^{\text {bcde }}$ & $0.26^{\beta}$ \\
\hline 9 & $10^{\circ} 27^{\prime}$ & $51^{\circ} 32^{\prime}$ & 320 & $S$ & 4 & 650 & 7.8 & 98 & 27.3 & $3.5^{\mathrm{a}}$ & $19.3^{\text {cde }}$ & $0.56^{\alpha \beta}$ \\
\hline 10 & $10^{\circ} 52^{\prime}$ & $51^{\circ} 24^{\prime}$ & 320 & NW & 5 & 580 & 7.8 & 139 & 37.7 & $4.3^{a}$ & $19.1^{\text {cde }}$ & $0.48^{\alpha \beta}$ \\
\hline 11 & $11^{\circ} 27^{\prime}$ & $51^{\circ} 10^{\prime}$ & 280 & NW & 2 & 580 & 8.0 & 99 & 36.8 & $5.9^{a}$ & $23.0^{\mathrm{abcd}}$ & $0.16^{\beta}$ \\
\hline 12 & $11^{\circ} 25^{\prime}$ & $51^{\circ} 20^{\prime}$ & 230 & SW & 5 & 550 & 8.3 & 131 & 33.1 & $5.0^{\mathrm{a}}$ & $23.8^{a b}$ & $1.23^{\alpha \beta}$ \\
\hline 13 & $11^{\circ} 26^{\prime}$ & $51^{\circ} 19^{\prime}$ & 240 & SE & 3 & 550 & 8.3 & 132 & 39.4 & $5.0^{\mathrm{a}}$ & $20.1^{\text {bcde }}$ & $1.10^{\alpha \beta}$ \\
\hline 14 & $11^{\circ} 25^{\prime}$ & $51^{\circ} 22^{\prime}$ & 280 & NW & 1 & 520 & 8.0 & 123 & 48.8 & $5.0^{a}$ & $18.6^{\mathrm{de}}$ & $0.68^{\alpha \beta}$ \\
\hline
\end{tabular}


The investigation took place from 2003 to 2005, three years with highly contrasting precipitation and temperature regimes. The summer of 2003 was the hottest summer in the region since 1901 , with about $20 \%$ less annual precipitation than the long-term average in the study area. In contrast, the summer of 2004 was up to $20 \%$ wetter than the average record for the study area. In the summer of 2005, the precipitation regime was closer to the average.

\section{Measurement of climate, edaphic and stand structural parameters}

Mean annual precipitation and temperature were derived from weather station data corrected for altitude. For the moistest and the driest stand, the amount of precipitation estimated from the weather station data was validated by rain gauge measurements in the stand in the 2004 growing season. We were not able to monitor soil moisture continuously at the 14 sites; however, soil moisture measurements with a mobile TDR probe (Trime-FM2, Imko, Ettlingen, Germany) were conducted every second month in 0-20 cm soil depth (including the organic layer) at ten randomly chosen locations in all stands. In addition, one beech stand each at the moist and dry end of the transect was equipped with continuously logging TDR- and tensiometer stations in 2003 (\#1 and \#14; $15-20 \mathrm{~cm}$ depth; data for the moist site according to Meesenburg (unpubl.)). According to these occasional and continuous soil moisture measurements, the lower rainfall at the dry end is corresponding to lower absolute soil moisture minima and a longer duration of low soil water contents in summer in comparison to the sites at the moist end of the gradient as expected from the rainfall data (Fig. 1a and b).
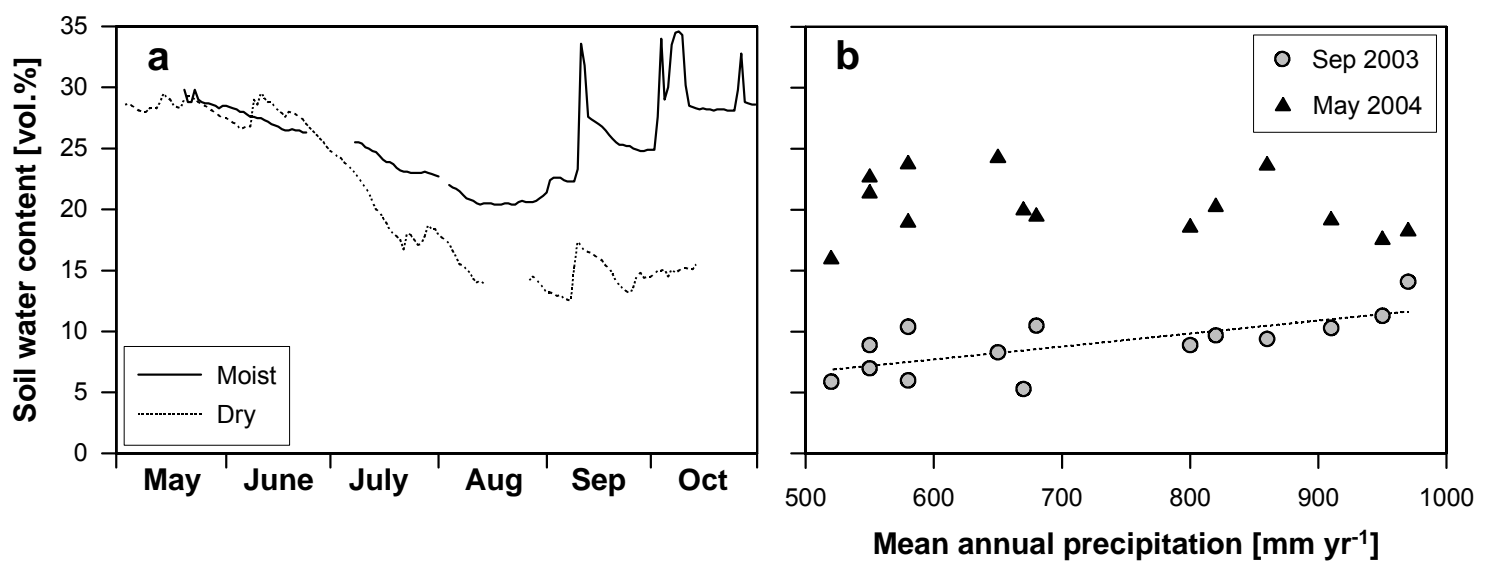

Figure 1a. Soil water content $(15-20 \mathrm{~cm})$ in beech stands at the moist $\left(>950 \mathrm{~mm} \mathrm{yr}^{-1}\right)$ and the dry end $\left(<550 \mathrm{~mm} \mathrm{yr}^{-1}\right)$ of the investigated precipitation gradient in central Germany. Values given are data for the growing season in the dry year 2003. Data for the moist beech stand according to Meesenburg (unpubl.) and for the dry beech stand according to Burk (2006). Figure 1b. Relationship between mean annual precipitation and soil water content $(0-20 \mathrm{~cm})$ in spring and late summer in 14 beech stands along the precipitation gradient in central Germany (mean of ten sampling points per study site). Values given are data for September 2003 at the end of a dry summer and for May 2004 at the time of leaf flush (Sep 2003: $y=1.3+0.01 x, r^{2}=0.50, p=0.002 ;$ May 2004: $\left.r^{2}=0.06, p=0.21\right)$. 
Air temperature in $1.3 \mathrm{~m}$ height and soil temperature in $10 \mathrm{~cm}$ depth were continuously measured with i-button sensors (Thermochron, Maxim, Dallas, USA) from July 2004 to June 2005.

A soil profile examination was carried out at every study site in a soil pit in the centre of the plot in April 2004 following the criteria of 'Arbeitskreis Standortskartierung' (1996). Soil samples were taken at five randomly chosen locations within the plot at 0-10 and $10-20 \mathrm{~cm}$ soil depth. Sample preparation and chemical analyses followed mainly the protocol given by 'Bundesweite Bodenzustandserhebung im Wald' (BMELF 1994). Additionally, plant available phosphorus according to Bowman \& Cole (1978) was extracted by resin bags that were placed for $16 \mathrm{~h}$ in a solution of $1 \mathrm{~g}$ soil material suspended in $30 \mathrm{ml}$ water (Sibbesen 1977). The phosphorus was re-exchanged by $\mathrm{NaCl}$ and $\mathrm{NaOH}$ solutions and analysed by blue-dyeing (Murphy \& Riley 1962) and photometric measurement.

Mean diameter at breast height $(\mathrm{dbh})$, stem basal area in $1.3 \mathrm{~m}$ height and stem density were determined in January 2004 for all stems in the $30 \times 30$ m study plots. Eight dominant trees in the canopy were randomly chosen within each study plot and measured for tree height with an optical tree height meter (Vertex III, Haglöf, Sweden). Stand leaf mass ( $\mathrm{M}_{\mathrm{l}}$, which equals annual leaf production) and leaf area index (LAI) were recorded by litter trapping in 2003 and 2004 in all 14 stands (for measuring details see Chapter III).

\section{Fine root sampling and analyses}

In 2003, profile totals of fine root biomass and necromass of beech were investigated by soil coring to $40 \mathrm{~cm}$ depth in all 14 forest stands. This data was extrapolated to $120 \mathrm{~cm}$ depth using depth functions of fine root biomass established in a related, earlier study by Hertel (1999) in four stands. The percentage of fine root biomass in 40$120 \mathrm{~cm}$ of the earlier study was correlated with annual precipitation; the percentage was calculated for every annual precipitation amount of this study and subsequently related to the measured fine root biomass in $0-40 \mathrm{~cm}$ depth. Due to the enormous labour effort required for investigating 14 stands, the sampling program had to be reduced in 2004 and 2005. In 2004, nine stands selected along the full transect were studied in the organic layer and the mineral soil to $40 \mathrm{~cm}$ soil depth. In 2005 , fine root mass was investigated in the organic layer and the mineral soil to $10 \mathrm{~cm}$ soil depth in 13 stands and extrapolated to $20 \mathrm{~cm}$ depth according to the results of the two former years. For being able to compare the standing stock of fine root biomass in the stands, each one sampling campaign was conducted in the summer months (June - 
September) of the three study years. Because the root samples had to be processed within four weeks after coring, the sites were investigated sequentially in three distinct periods of the summer. To avoid seasonal bias, the sites covered in the three sampling periods were evenly distributed over the whole transect. Each 12 root samples per stand were taken with a soil corer $(4 \mathrm{~cm}$ in diameter) from the uppermost $40 \mathrm{~cm}$ of the soil profile (including the organic layer) at random coordinates within the $30 \times 30 \mathrm{~m}$ plots, and divided into five sub-samples (organic layer, 0-10, 10-20, 20-30, and 30$40 \mathrm{~cm}$ ). The material was immediately transported to the laboratory and stored at $6^{\circ} \mathrm{C}$ for no longer than four weeks. Only roots $<2 \mathrm{~mm}$ in diameter were considered for analysis. In a few stands, small amounts of fine roots of herbaceous species or tree species other than beech were present; they were discarded. Large fine root segments (>10 $\mathrm{mm}$ in length) were picked out by hand and sorted into live and dead fine root mass under a stereo-microscope (40x). Criteria for assessing root vitality were the colour and structure of the root surface, root elasticity and turgescence, branching structure, and the degree of cohesion of cortex, periderm and stele (for criteria see Persson 1978, Leuschner et al. 2001b).

With this procedure, the largest part of the fine root biomass fraction is obtained, while only a small proportion of the mostly detritus-like fine root necromass is detected (Bauhus \& Bartsch 1996, Hertel \& Leuschner 2002). For increasing the accuracy of both the biomass and necromass analysis, we subjected every third root sample of the 2005 campaign to an in-depth microscopic analysis for even smallest root fragments, adopting a method introduced by Van Praag et al. (1987) and modified by Hertel \& Leuschner (2002). The additional root bio- and necromass obtained by this procedure was added to the fraction of large root segments. In the samples without a detailed analysis, a corresponding fraction was added to the biomass and necromass values. Fine root biomass and necromass were expressed as profile totals (organic layer plus 0-40 or 0-20 $\mathrm{cm}$ of mineral soil, respectively; in $\mathrm{g} \mathrm{m}^{-2}$ ). Specific fine root surface area (SRA, in $\mathrm{cm}^{2} \mathrm{~g}^{-1}$ ) was determined in one randomly selected intact fine root system segment of about $20 \mathrm{~cm}$ length per sample by optical surface measurement with a flatbed scanner and the program WinRHIZO (Régent Instruments, Quebec, Canada), and subsequent drying $\left(48 \mathrm{~h}, 70^{\circ} \mathrm{C}\right)$. The cumulative fine root surface area index (RAI) was obtained by multiplying fine root biomass $\left(\mathrm{g} \mathrm{m}^{-2}\right)$ with SRA.

Fine root biomass samples were extracted in July 2005 for analysing the carbon isotope composition of the dry matter by mass spectroscopy (Delta plus, ThermoFinnigan, USA; $n=12$ per stand). For comparison, leaves of the upper sun canopy were sampled with a crossbow in six of the 14 stands and analysed for $\delta^{13} \mathrm{C}$ as well $(n=6$ per stand). 
The ingrowth core method was used for assessing the growth potential of the fine roots in the 14 stands. This technique is not suitable for measuring the actual growth rate of fine roots (Steele et al. 1997, Hertel \& Leuschner 2002), but it may give relative values of the growth potential and regeneration ability of fine roots after disturbance in a larger number of different forest stands under the local conditions (e.g., Neill 1992, Makkonen \& Helmisaari 1999, Higgins et al. 2002, Jones et al. 2003, Majdi et al. 2005). In each stand, twenty-four soil cores of $5.5 \mathrm{~cm}$ in diameter and $10 \mathrm{~cm}$ soil depth were extracted in June 2003 at random coordinates, all macroscopically visible root mass sorted out by hand on site, and the soil material immediately and carefully refilled into the hole. The core locations were marked with several flags for re-sampling. We attempted to manually re-establish the original bulk density and layering of the soil in the cores as close as possible. The re-colonisation of the soil cores was controlled after 12 months in four cores that were extracted and analysed in June 2004; all cores showed the beginning of vital ingrowth of beech fine roots from the surrounding soil. The remaining 20 cores per stand were harvested in May 2005 after 23 months of exposure and analysed for their fine root biomass, as described above. By relating root increment per year to the standing stock of fine root biomass in the direct proximity of the cores, we calculated relative fine root ingrowth rate as a rough estimate of root turnover (in $\mathrm{yr}^{-1}$ ).

\section{Statistical analyses}

Statistical analyses were conducted with the package SAS, version 8.2 (Statistical Analyses System, SAS Institute Inc., Cary, NC, USA). Means and standard errors of root parameters were calculated from each 12 sampling locations per study site (ingrowth core experiment: 20). Probability of fit to normal distribution was tested by a Shapiro-Wilk test. The study site means were compared with a one-factorial analysis of variance followed by a Scheffé test. The number of edaphic, stand structural, climatic and topographic parameters to be considered in the subsequent analysis was reduced using a principal components analysis (PCA; Table 2). Those PCA axes that were explaining $\geq 75 \%$ of the respective variance were used as independent variables in subsequent multiple regression analyses with backward variable elimination to test whether the PCA-derived variables were significant predictors for fine root biomass, productivity, or relative fine root ingrowth rate. The multiple regression analyses were accompanied by single-factor linear regression analyses to quantify the influence of the most influential parameters of each PCA-derived variable on fine root mass. The influence of precipitation and temperature on fine root biomass, productivity, and relative ingrowth rate was investigated in more detail by differentiating between possible effects of the current year, of the preceding year, or of the long-term average. 
Significance was determined at $p \leq 0.05$ in most tests; in a few cases, $p \leq 0.1$ was used to indicate weak significance.

Table 2. Principal components analyses on the importance of various edaphic, stand structural, climatic, and topographic parameters in the 14 mature beech stands. The most characteristic variables (according to their loading) of each PCA axis are in bold. $\mathrm{P}_{\mathrm{a}}=$ plant-available phosphorus; $\mathrm{Ca}, \mathrm{Mg}, \mathrm{K}=\mathrm{NH}_{4} \mathrm{Cl}-$ exchangeable $\mathrm{Ca}, \mathrm{Mg}$ or $\mathrm{K}$ cations.

\begin{tabular}{|c|c|c|c|}
\hline PCA & Axis 1 & Axis 2 & Axis 3 \\
\hline $\begin{array}{l}\text { Edaphic parameters } \\
\text { Eigenvalue }\end{array}$ & $\begin{array}{l}\text { Soil } 1 \\
0.461\end{array}$ & $\begin{array}{l}\text { Soil } 2 \\
0.209\end{array}$ & $\begin{array}{l}\text { Soil } 3 \\
0.126\end{array}$ \\
\hline $\begin{array}{l}\mathrm{pH}\left(\mathrm{H}_{2} \mathrm{O}\right) \\
\mathrm{C} / \mathrm{N} \\
\mathrm{Pa}_{\mathrm{a}} \\
\mathrm{N} / \mathrm{P}_{\mathrm{a}} \\
\mathrm{CEC} \\
\text { Base saturation } \\
\mathrm{Ca} \\
\mathrm{Mg} \\
\mathrm{K}\end{array}$ & $\begin{array}{r}\mathbf{0 . 8 4 3} \\
-0.567 \\
0.239 \\
-0.042 \\
\mathbf{0 . 8 0 4} \\
\mathbf{0 . 9 1 0} \\
\mathbf{0 . 8 8 4} \\
0.515 \\
0.731\end{array}$ & $\begin{array}{r}0.311 \\
-0.041 \\
-0.909 \\
0.907 \\
0.017 \\
0.009 \\
0.074 \\
-0.353 \\
0.088\end{array}$ & $\begin{array}{r}-0.237 \\
0.722 \\
0.098 \\
0.096 \\
0.544 \\
-0.018 \\
0.424 \\
-0.216 \\
-0.131\end{array}$ \\
\hline $\begin{array}{l}\text { Stand structural } \\
\text { parameters } \\
\text { Eigenvalue }\end{array}$ & $\begin{array}{l}\text { Structure } 1 \\
0.408\end{array}$ & $\begin{array}{l}\text { Structure } 2 \\
0.304\end{array}$ & $\begin{array}{l}\text { Structure } 3 \\
0.192\end{array}$ \\
\hline $\begin{array}{l}\text { Stand age } \\
\text { Tree height } \\
\text { Stem density } \\
\text { dbh } \\
\text { Stem basal area }\end{array}$ & $\begin{array}{r}-0.562 \\
-0.558 \\
0.737 \\
-0.930 \\
-0.117\end{array}$ & $\begin{array}{l}0.371 \\
0.138 \\
0.659 \\
0.092 \\
\mathbf{0 . 9 6 0}\end{array}$ & $\begin{array}{r}0.614 \\
-0.749 \\
-0.090 \\
0.026 \\
-0.068\end{array}$ \\
\hline $\begin{array}{l}\text { Climatic and topo- } \\
\text { graphic parameters } \\
\text { Eigenvalue }\end{array}$ & $\begin{array}{l}\text { Climate } 1 \\
0.613\end{array}$ & $\begin{array}{l}\text { Climate } 2 \\
0.175\end{array}$ & \\
\hline $\begin{array}{l}\text { Inclination } \\
\text { Altitude } \\
\text { Precipitation } \\
\text { Soil moisture } \\
\text { Air temperature } \\
\text { Soil temperature }\end{array}$ & $\begin{array}{r}0.374 \\
\mathbf{0 . 8 6 6} \\
\mathbf{0 . 8 4 3} \\
0.614 \\
-0.866 \\
-\mathbf{0 . 8 0 0}\end{array}$ & $\begin{array}{r}0.643 \\
0.242 \\
-0.146 \\
-0.605 \\
-0.243 \\
0.208\end{array}$ & \\
\hline
\end{tabular}




\section{Results}

\section{Stand fine root biomass and necromass}

Beech fine root biomass $\left(\mathrm{FRB}_{\mathrm{p}}\right)$ in the 14 stands varied in 2003 between 107 and $531 \mathrm{~g} \mathrm{~m}^{-2}$ in the soil profile to $40 \mathrm{~cm}$ depth (including the organic layer), and between 120 and $583 \mathrm{~g} \mathrm{~m}^{-2}$ in the profile to $120 \mathrm{~cm}$ depth (extrapolated data; Fig. 2a). For the soil profile to $20 \mathrm{~cm}$ depth, the mean $\mathrm{FRB}_{\mathrm{p}}$ value of the stands was $226 \mathrm{~g} \mathrm{~m}^{-2}$ in the summer of 2003, $197 \mathrm{~g} \mathrm{~m}^{-2}$ in 2004 and $173 \mathrm{~g} \mathrm{~m}^{-2}$ in 2005. Plotting fine root biomass against mean annual precipitation revealed a significant or weakly significant $(0.02<p<0.09)$ decrease of $\mathrm{FRB}_{\mathrm{p}}$ with decreasing precipitation along the gradient in the dry summer of 2003 and the wet summer of 2004 (2003: $p=0.03, r=+0.53$; 2004: $p=0.09, r=+0.50$; Fig. $2 b$ ). Fine root biomass decreased toward the drier stands not only in the $0-20 \mathrm{~cm}$ profile, but also in the $0-40$ and the $0-120 \mathrm{~cm}$ profiles $(p=0.03$ and 0.05 , respectively; data not shown). The slope of the regression lines for the 20,40 and $120 \mathrm{~cm}$ profiles indicates a decrease of $\mathrm{FRB}_{\mathrm{p}}$ by about $30 \mathrm{~g} \mathrm{~m}^{-2}$ per precipitation reduction of $100 \mathrm{~mm} \mathrm{yr}^{-1}$ in 2003 and 2004. Thus, beech stands growing with less than $550 \mathrm{~mm} \mathrm{yr}^{-1}$ of precipitation had, on average, a by $35 \%$ smaller profile total of fine root biomass than stands receiving more than $950 \mathrm{~mm} \mathrm{yr}^{-1}$. In the year 2005, $\mathrm{FRB}_{\mathrm{p}}$ also tended to decrease toward the drier stands, but the decrease was less steep and not significant.

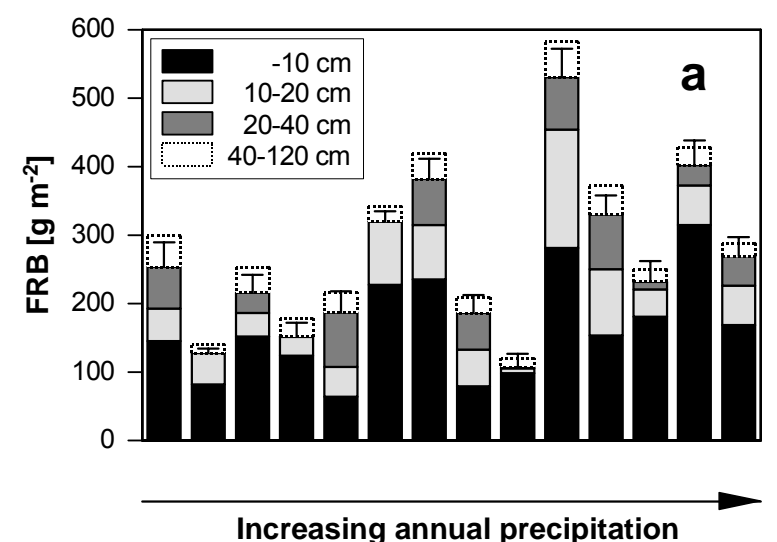

Figure 2a. Profile totals of fine root biomass $\left(\mathrm{FRB}_{p}\right)$ in 2003 in the organic layer and the mineral soil to $40 \mathrm{~cm}$ depth in 14 mature beech stands along a precipitation gradient in central Germany (mean and standard error of 12 profiles per study site). Dotted bar sections indicate extrapolated biomass to $120 \mathrm{~cm}$ depth as derived from fine root depth-relationships established in four representative soil profiles. Figure 2b. Relationship between mean annual precipitation and fine root biomass (FRB) in the organic layer and the mineral soil until $20 \mathrm{~cm}$ depth in beech stands along a precipitation gradient in central Germany in 2003 (13 stands), 2004 (nine stands) and 2005 (12 stands) (mean of 12 profiles per study site; 2003: $\left.r^{2}=0.28, p=0.03 ; 2004: r^{2}=0.25, p=0.09 ; 2005: r^{2}=0.11, p=0.15\right)$. 
For the fine root necromass total in the profile $\left(F R N_{p}\right)$, we found no significant decrease with declining precipitation in 2003, 2004 or 2005 (data not shown). The $\mathrm{FRN}_{\mathrm{p}}$ means of the 14 stands were 287, 192 and $182 \mathrm{~g} \mathrm{~m}^{-2}$ in the summers of 2003, 2004 and 2005, respectively. The fine root biomass/necromass ratio was less than unity in 2003 , but close to one in 2004 and 2005.

\section{Vertical distribution of fine roots}

In all 14 stands of the gradient, beech fine roots showed highest densities in the uppermost soil layers; root density decreased exponentially with soil depth. In both the high and low precipitation stands, more than $75 \%$ of the profile total of fine root biomass (extrapolated to $120 \mathrm{~cm}$ depth) occurred in the $0-20 \mathrm{~cm}$ layer plus organic layer (Fig. 2a). However, the root biomass in the organic layer greatly increased toward the moist end of the gradient, where this layer had higher moisture contents during the summer than at the dry end. In the low precipitation stands, only negligible amounts of fine root biomass occurred in the organic layer and nearly all fine roots were located in the mineral soil to $40 \mathrm{~cm}$ depth. In contrast, the organic layer contained up to $46 \%$ of $\mathrm{FRB}_{\mathrm{p}}$ in the high precipitation stands. The relative importance of the organic layer in the profile total of fine root biomass increased exponentially with increasing precipitation in all summers (significant trend); however, the increase was most pronounced in the dry summer of 2003 (Fig. 3). Since the organic layer on top of the soil showed a considerable variability among the 14 stands, we found a high coefficient of variation (CV) for the fine root biomass stock in this horizon (160\%), which was much larger than the CV of the root biomass in the mineral soil $(50-60 \%$ for the $0-10$ and $10-20 \mathrm{~cm}$ layers).

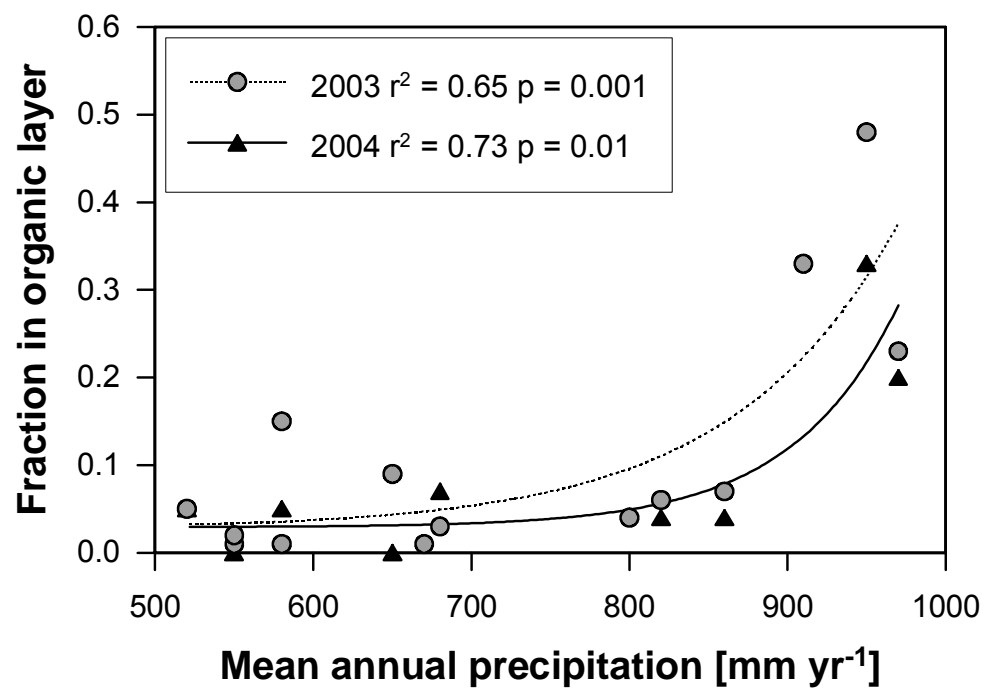

Figure 3. Relationship between mean annual precipitation and the fraction of fine roots contained in the organic layer (in relation to the profile total of fine roots until $40 \mathrm{~cm}$ depth) in the beech stands in 2003 (14 stands) and 2004 (nine stands; mean of 12 profiles per study site). 
Morphology, surface area, and $\delta^{13} \mathrm{C}$ of the fine roots and root/shoot carbon partitioning

While the mean of fine root specific surface area (SRA) was similar for high- and lowprecipitation stands in the dry summer of 2003, SRA significantly increased toward the drier stands in the wetter summers of 2004 and 2005 (Fig. 4a). Hence, stands with less than $550 \mathrm{~mm} \mathrm{yr}^{-1}$ of precipitation had average SRA values of about $400 \mathrm{~cm}^{2} \mathrm{~g}^{-1}$, those with $>950 \mathrm{~mm} \mathrm{yr}^{-1}$ of only about $290 \mathrm{~cm}^{2} \mathrm{~g}^{-1}$.

Thus, the fine roots of the drier stands were on average thinner than those of the moister stands, at least in 2004 and 2005. Based on the FRB and SRA data, we calculated cumulative fine root surface area indices (RAl) of 6.3 and $5.2 \mathrm{~m}^{2} \mathrm{~m}^{-2}$ in 2004 and 2005, respectively, with no significant dependency on precipitation amount (Fig. 4b). In contrast, in the dry summer of 2003, RAl decreased from $7.2 \mathrm{~m}^{2} \mathrm{~m}^{-2}$ in stands with $>950 \mathrm{~mm} \mathrm{yr}^{-1}$ to $4.2 \mathrm{~m}^{2} \mathrm{~m}^{-2}$ in stands with $<550 \mathrm{~mm} \mathrm{yr}^{-1}$ of precipitation.
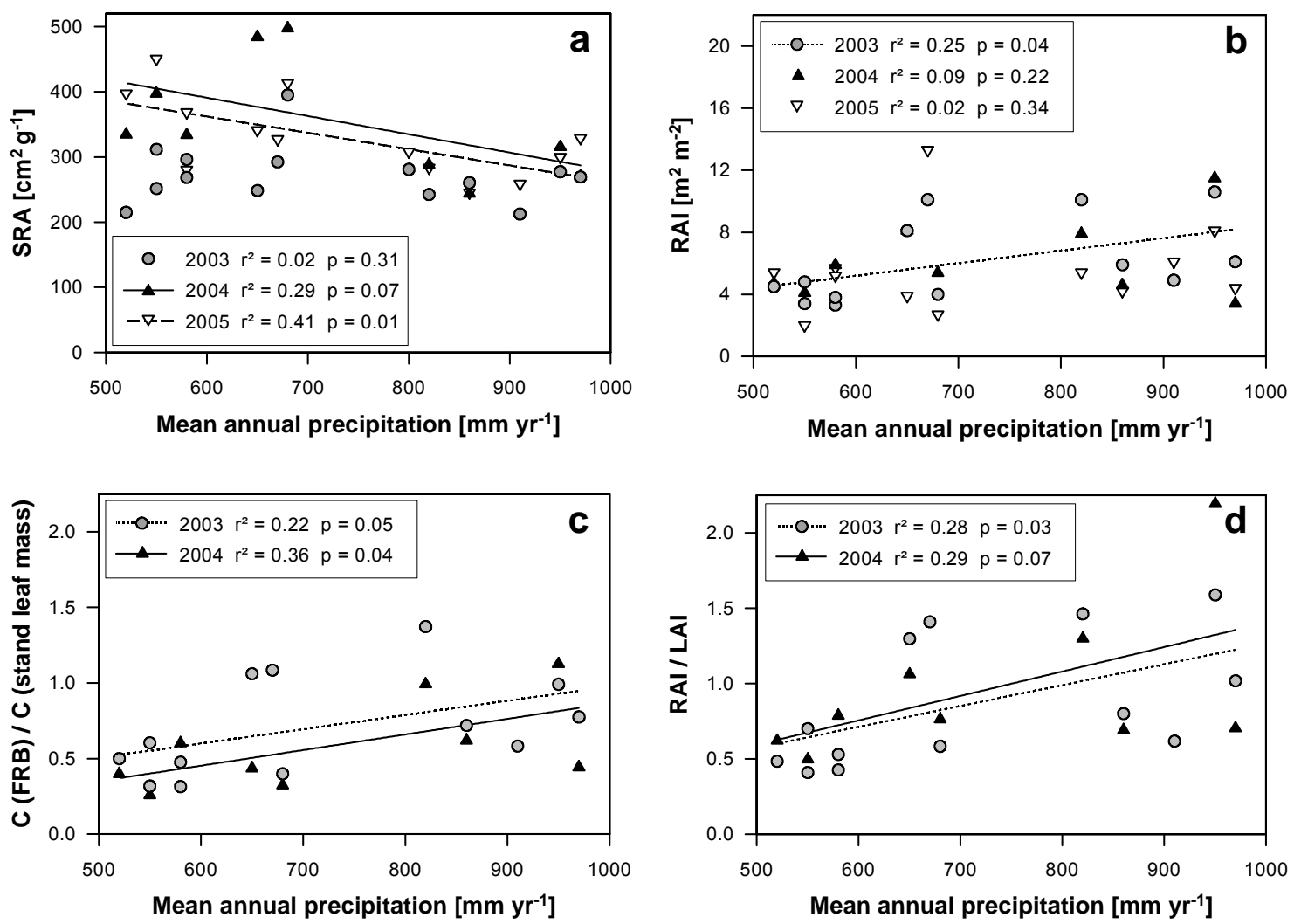

Figure 4a-b. Relationship between mean annual precipitation and specific fine root surface area (SRA) or cumulative fine root area per ground area (RAI) in the organic layer and the mineral soil to $20 \mathrm{~cm}$ depth in the beech stands in 2003 (14 stands), 2004 (nine stands) and 2005 (13 stands; mean of 12 samples per study site). Figure 4c. Relationship between mean annual precipitation and C-partitioning to fine root biomass (FRB) vs. leaf mass in the beech stands in 2003 (13 stands) and 2004 (nine stands). Leaf litter fall was used as an estimate of stand leaf mass. Figure 4d. Relationship between mean annual precipitation and the root area index (RAI)/leaf area index (LAI) ratio in the two years. 
Both the carbon partitioning ratio, i.e., the $C$ invested in fine root mass vs. $C$ invested in leaf mass, and the area index ratio of fine roots to leaves significantly increased toward the moister stands in the dry summer 2003 and the wet summer 2004 (Fig. 4c-d). Stands with less than $550 \mathrm{~mm} \mathrm{yr}^{-1}$ had on average a $52 \%$ smaller C-partitioning to fine roots and a $60 \%$ smaller root to leaf area index ratio than those with more than $950 \mathrm{~mm} \mathrm{yr}^{-1}$.

The $\delta^{13} \mathrm{C}$-signature of fine root biomass sampled in July 2005 varied between $-28.2 \%$ o and $-25.6 \%$ in the 14 stands. The discrimination of ${ }^{13} \mathrm{C}$ was more or less similar for the stands with 750 to $970 \mathrm{~mm} \mathrm{yr}^{-1}(-27.3$ to $-28.2 \%$ ). However, in stands with less than $650 \mathrm{~mm} \mathrm{yr}^{-1}$, the mean $\delta^{13} \mathrm{C}$ of fine roots steeply increased up to $-25.6 \%$ (Fig. 5). Beech sun leaves were on average by $1.5 \%$ isotopically lighter than the fine roots in the same stand. The $\delta^{13} \mathrm{C}$-signature of the leaves decreased linearly with decreasing rainfall from $-29.6 \%$ to $-28.1 \%$ from the moist to the dry end of the gradient.

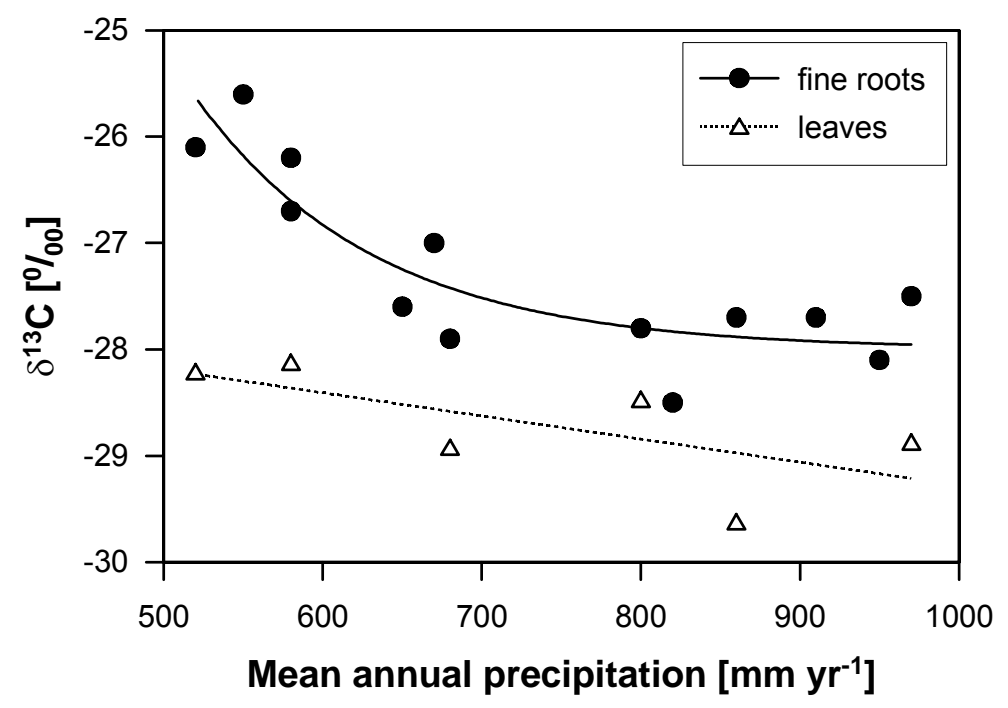

Figure 5. Relationship between mean annual precipitation and the $\delta^{13} \mathrm{C}$-signature of fine roots and sun leaves in July 2005 in 13 and six mature beech stands, respectively, along the precipitation gradient (mean of 12 or six samples per study site; fine roots: $y=-28+\exp (-0.01(x-618)) ; r^{2}=0.78, p<0.001$; leaves: -27.1 $0.002 x ; r^{2}=0.45, p=0.07$ ). 


\section{Fine root productivity and relative ingrowth rate}

Fine root productivity in the organic layer and the upper $10 \mathrm{~cm}$ of the soil as estimated with ingrowth cores ranged from 21 to $63 \mathrm{~g} \mathrm{~m}^{-2} \mathrm{yr}^{-1}$ in the 14 stands. It must be kept in mind that the magnitude of these production values is questionable due to the unknown starting point of fine root ingrowth into the cores. Beech stands with high $\left(>900 \mathrm{~mm} \mathrm{yr}^{-1}\right)$ or low precipitation $\left(<550 \mathrm{~mm} \mathrm{yr}^{-1}\right.$ ) had similar average productivity values (41 and $36 \mathrm{~g} \mathrm{~m}^{-2} \mathrm{yr}^{-1}$, data not shown), indicating a weak or missing dependence of fine root productivity on precipitation.

In contrast, when the growth rate in the soil cores is expressed in relation to the fine root stock in the soil close to the cores, an increase in relative fine root productivity with decreasing precipitation is observed (Fig. 6). Relative root ingrowth rate, i.e., productivity per standing stock, increased with decreasing precipitation from $0.2 \mathrm{yr}^{-1}$ at the moist end to $0.5 \mathrm{yr}^{-1}$ at the dry end of the transect. Again, the absolute height of these values of fine root ingrowth is most likely unreliable due to the mentioned methodological drawbacks of the ingrowth core method.

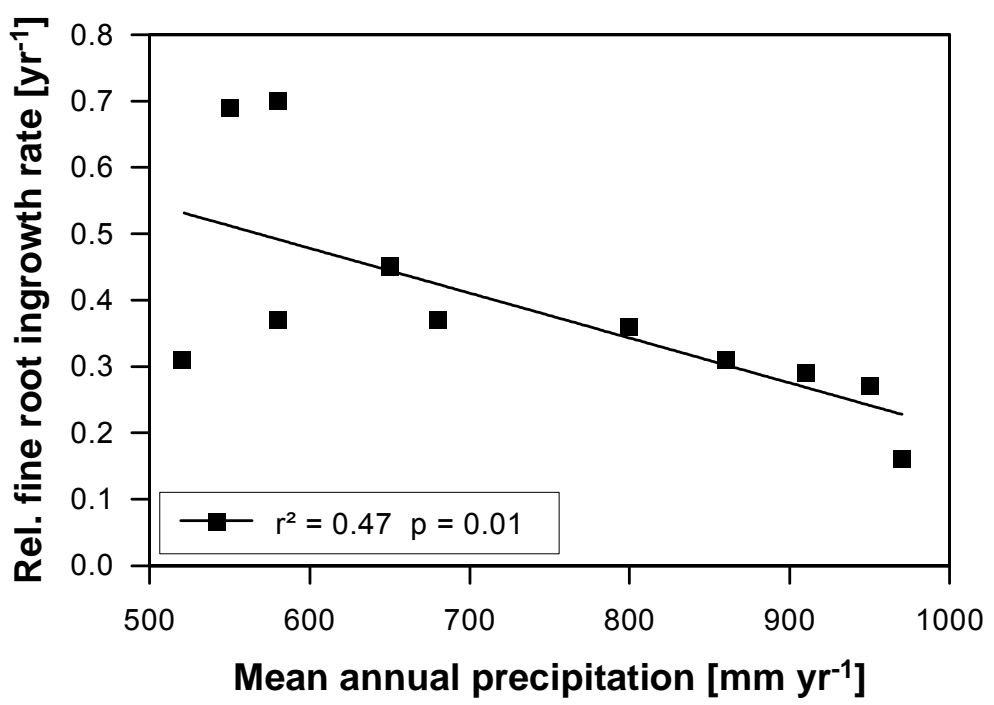

Figure 6. Relationship between mean annual precipitation and relative fine root ingrowth rate in the organic layer and the mineral soil to $10 \mathrm{~cm}$ depth in 11 mature beech stands along the precipitation gradient (mean of 20 ingrowth core experiments per study site). The ingrowth cores were exposed in the period June 2003 to May 2005. Relative ingrowth rate was calculated as root productivity per root standing stock. 


\section{Discussion}

\section{Stand fine root biomass and water availability}

This study revealed a substantial decrease in the fine root biomass of beech forests with a decrease in precipitation: stands with less than $550 \mathrm{~mm} \mathrm{yr}^{-1}$ had a by $35 \%$ smaller profile total of fine root biomass and a by $52 \%$ smaller fine root/leaf biomass ratio than stands with more than $950 \mathrm{~mm} \mathrm{yr}^{-1}$. Two of the drier stands had fine root profile totals of less than $150 \mathrm{~g} \mathrm{~m}^{-2}$ in the $0-40 \mathrm{~cm}$ profile (including the organic layer); these values are among the lowest that have been reported for Fagus sylvatica forests in Europe (Leuschner \& Hertel 2003) and they are at the lower limit of $F^{2} B_{p}$ values found in temperate forests around the world (Vogt et al. 1996).

A decrease in $\mathrm{FRB}_{\mathrm{p}}$ with decreasing precipitation is in line with results obtained in Sitka spruce and Norway spruce stands differing in water availability (Nisbeth \& Mullins 1986, Leuschner \& Hertel 2003) and it supports the conclusions drawn from a metaanalysis of fine root biomass data in European beech forests across a broad climatic range (Leuschner \& Hertel 2003). Thus, beech forests seem to be able to meet their water demands in drier environments with a remarkably small fine root biomass and total fine root surface area. This finding seems to contradict the optimal partitioning theory in plants, which predicts an increase in root growth relative to leaf growth upon drought in order to maximise the efficiency of water capture by relative increase in the root absorbing surface, thereby reducing water limitation. A closer inspection of the optimal partitioning theory with its focus on carbon investment and biomass allocation suggests that the related assumptions of this theory are too simple when applied to root water uptake. There is evidence that water uptake by the root system of trees is more dependent on the specific uptake rate of the absorbing fine roots, i.e., the driving root-soil water potential gradient and the radial hydraulic conductivity of the root, than on the total surface area of the root system itself (Leuschner et al. 2003). For example, by comparing dry and moist beech stands, Burk (2006) found that beech had higher surface-specific water uptake rates in the stand with lower annual precipitation than in the moister stand, despite a lower fine root biomass at the dry site. In this study, root water uptake was primarily controlled by the water potential gradient between soil and root xylem. Thus, mature trees seem to be able to maintain root water absorption in a drying soil solely by lowering their root water potential and hence increasing absorption per unit root surface, at least during mild drought periods. This indicates that physiological acclimation processes are equally important, or even more important, than morphological changes, which would alter root system size. Because of its focus on allocation patterns rather than the physiology of resource capture, the optimal 
partitioning theory may not be adequate for explaining the response of beech root systems to water shortage under field conditions.

The relationship between water availability and root system size is further complicated by the fact that root growth and mortality may depend more on nutrient supply than on water availability, thereby possibly overriding any effect of water shortage on carbon allocation to fine root growth. Soil nitrogen availability has been found to influence fine root production and the root standing stock of trees negatively (Tisdale et al. 1985, Côté et al. 1998, Lauenroth \& Gill 2003). In the present study, N-availability, as reflected by soil $\mathrm{C} / \mathrm{N}$ ratio, tended to be higher at the dry than the moist end of the transect, probably due to lower nitrate leaching losses in the drier climate. However, the multiple regression analysis did not show a $\mathrm{C} / \mathrm{N}$ effect on fine root biomass (Table 3), which seems to contradict the above-cited observations from other studies. On the other hand, plant-available phosphorus had a significant negative effect on $\mathrm{FRB}_{\mathrm{p}}$ in 2005 and a weakly significant effect in the other two years (Tables 3 and 4). Additionally, at least in the summer of 2004, the somewhat higher temperature in the drier section of the gradient should have negatively affected fine root biomass, since the standing stock of tree fine roots generally tends to decrease with increasing temperature (Vogt et al. 1996, Leuschner \& Hertel 2003).

Table 3. Multiple regression analysis with backward variable elimination on the effects of the parameter groups soil, stand structure, and climate on fine root biomass, productivity, and relative ingrowth rate in the 14 mature beech stands in 2003, 2004 and 2005 (see also table 2). Values given are the determination coefficient $r^{2}$ and the probability of error $p$ for the model and the $F$-value and probability of error $p$ for the selected predictors. The + or - signs at the predictor variables indicate positive or negative relationships. Fine root productivity and relative fine root ingrowth rate was estimated by the ingrowth core approach in the period from June 2003 to May 2005. n.s. = not significant.

\begin{tabular}{|c|c|c|c|c|c|c|c|}
\hline \multirow[b]{2}{*}{$\mathbf{Y}$} & & \multicolumn{2}{|c|}{ Model } & & \multirow[b]{2}{*}{ Predictor } & \multirow[b]{2}{*}{$\boldsymbol{F}$} & \multirow[b]{2}{*}{$\mathbf{p}$} \\
\hline & & $\mathbf{r}^{2}$ & $\mathbf{p}$ & & & & \\
\hline \multirow[t]{5}{*}{ Fine root biomass } & 2003 & 0.38 & 0.03 & + & Climate 1 & 6.7 & 0.03 \\
\hline & 2004 & & n.s. & & & & \\
\hline & 2005 & 0.75 & 0.01 & + & Climate 2 & 10.6 & 0.01 \\
\hline & & & & + & Soil 2 & 7.4 & 0.03 \\
\hline & & & & + & Climate 1 & 7.3 & 0.03 \\
\hline \multicolumn{2}{|c|}{ Fine root productivity } & & n.s. & & & & \\
\hline \multicolumn{2}{|c|}{ Relative fine root ingrowth rate } & 0.41 & 0.04 & - & Climate 1 & 5.7 & 0.04 \\
\hline
\end{tabular}


Table 4. Results of correlation analyses between fine root biomass, productivity or relative ingrowth rate and each seven different precipitation and temperature parameters for the dry year 2003, the wet year 2004 and the moderately dry year 2005, as well as plant-available phosphorus content $P_{a}$ and $N / P_{a}$ ratio in the mineral soil, and stem basal area. Values given are the Pearson correlation coefficient $r$ and the probability of error $p$. For either precipitation or temperature the following parameters were tested: longterm mean or total (1), long-term mean or total from May to September (2), long-term mean or total in April/May (3), mean or total of the study year (4), May to September mean or total of the study year (5), mean or total of the respective preceding year (2002, 2003 or 2004) (6), May to September mean or total of the respective preceding year ( 7$)$. All significant correlations $(p \leq 0.05)$ are in bold.

\begin{tabular}{|c|c|c|c|c|c|c|c|c|c|c|}
\hline & \multicolumn{6}{|c|}{ Fine root biomass } & \multirow{2}{*}{\multicolumn{2}{|c|}{$\begin{array}{c}\text { Fine root } \\
\text { productivity }\end{array}$}} & \multirow{2}{*}{\multicolumn{2}{|c|}{$\begin{array}{l}\text { Rel. fine root } \\
\text { ingrowth rate }\end{array}$}} \\
\hline & \multicolumn{2}{|c|}{2003} & \multicolumn{2}{|c|}{2004} & \multicolumn{2}{|c|}{2005} & & & & \\
\hline & $\mathbf{r}$ & p & $\mathbf{r}$ & $\mathbf{p}$ & $\mathbf{r}$ & $\mathbf{p}$ & $\mathbf{r}$ & p & $r$ & p \\
\hline Prec 1 & 0.53 & 0.03 & 0.50 & 0.09 & 0.33 & 0.15 & 0.03 & 0.46 & -0.69 & 0.01 \\
\hline Prec 2 & 0.54 & 0.03 & 0.53 & 0.07 & 0.24 & 0.23 & -0.01 & 0.48 & -0.64 & 0.02 \\
\hline Prec 3 & 0.53 & 0.03 & 0.47 & 0.10 & 0.27 & 0.20 & -0.02 & 0.48 & -0.50 & 0.06 \\
\hline Prec 4 & 0.55 & 0.03 & 0.51 & 0.08 & 0.42 & 0.09 & 0.11 & 0.37 & -0.70 & 0.01 \\
\hline Prec 5 & 0.68 & 0.01 & 0.58 & 0.05 & 0.29 & 0.19 & 0.06 & 0.43 & -0.65 & 0.01 \\
\hline Prec 6 & 0.53 & 0.03 & 0.46 & 0.11 & 0.43 & 0.08 & 0.10 & 0.38 & -0.66 & 0.01 \\
\hline Prec 7 & 0.49 & 0.04 & 0.51 & 0.08 & 0.41 & 0.09 & 0.10 & 0.39 & 0.03 & 0.46 \\
\hline Temp 1 & -0.41 & 0.07 & -0.63 & 0.03 & -0.27 & 0.19 & -0.04 & 0.45 & 0.53 & 0.05 \\
\hline Temp 2 & -0.41 & 0.07 & -0.65 & 0.03 & -0.30 & 0.16 & -0.02 & 0.47 & 0.52 & 0.05 \\
\hline Temp 3 & -0.40 & 0.08 & -0.65 & 0.03 & -0.24 & 0.22 & -0.03 & 0.47 & 0.51 & 0.06 \\
\hline Temp 4 & -0.39 & 0.08 & -0.62 & 0.04 & -0.29 & 0.17 & -0.05 & 0.43 & 0.52 & 0.05 \\
\hline Temp 5 & -0.43 & 0.06 & -0.65 & 0.03 & -0.29 & 0.17 & -0.04 & 0.46 & 0.53 & 0.05 \\
\hline Temp 6 & -0.40 & 0.08 & -0.59 & 0.05 & -0.29 & 0.17 & -0.05 & 0.43 & 0.52 & 0.05 \\
\hline Temp 7 & -0.43 & 0.06 & -0.65 & 0.03 & -0.30 & 0.09 & -0.01 & 0.49 & 0.53 & 0.05 \\
\hline Prec/Temp 1 & 0.58 & 0.02 & 0.54 & 0.07 & 0.35 & 0.13 & 0.02 & 0.48 & -0.69 & 0.01 \\
\hline Prec/Temp 4 & 0.60 & 0.02 & 0.55 & 0.06 & 0.43 & 0.08 & 0.09 & 0.39 & -0.71 & 0.01 \\
\hline Prec/Temp 6 & 0.57 & 0.02 & 0.50 & 0.08 & 0.45 & 0.07 & 0.09 & 0.39 & -0.68 & 0.01 \\
\hline $\mathbf{P}_{\mathbf{a}}$ & -0.37 & 0.09 & -0.51 & 0.08 & -0.56 & 0.02 & -0.37 & 0.13 & 0.10 & 0.39 \\
\hline $\mathrm{N} / \mathrm{P}_{\mathrm{a}}$ & 0.08 & 0.40 & 0.10 & 0.40 & 0.43 & 0.07 & -0.08 & 0.41 & 0.16 & 0.33 \\
\hline $\begin{array}{l}\text { Stem basal } \\
\text { area }\end{array}$ & -0.14 & 0.32 & 0.10 & 0.40 & 0.02 & 0.48 & 0.41 & 0.11 & 0.04 & 0.45 \\
\hline
\end{tabular}

Thus, it appears from the regression analyses that the amount of fine root biomass in the 14 beech stands is influenced by a combination of environmental factors including precipitation, temperature and plant-available phosphorus. The influence of precipitation (total of the study year or of the growing season or the long-term mean) was strongest in the dry summer of 2003 , while temperature was most influential in the wet summer of 2004 (Table 4). In 2003, fine root biomass was also significantly dependent on the precipitation/temperature quotient, which is probably a consequence 
of the negative correlation between mean annual precipitation and mean annual temperature in the gradient $\left(r^{2}=0.41, p=0.01\right)$.

Fine root productivity and relative ingrowth rate as influenced by water availability

The standing stock of fine root biomass is determined by the balance between fine root growth and fine root death. The onset of fine root growth in spring coincides with rising soil temperatures (Lyr \& Hoffmann 1967, Teskey \& Hinckley 1981, Kuhns et al. 1985, Davis et al. 2004). A higher root production in spring than in autumn, despite similarly favourable temperature and soil moisture conditions in both seasons, indicates that fine root growth in temperate trees is largely under endogenous control, i.e., should be determined by the strength of carbon sinks and sources in roots and leaves.

Fine root productivity as estimated by the ingrowth core method was neither influenced by precipitation or temperature, nor by $\mathrm{N}$ - or $\mathrm{P}$-availability in our gradient (Table 3 ). The lack of a drought effect on fine root growth may be explained by ample soil water reserves in all 14 stands in May 2004 (16 to 24 vol.\%; Fig. 1b). Thus, all stands must have received sufficient precipitation amounts in winter to replenish the soil water deficit of the preceding extremely dry late summer and to reach field capacity of soil water in May. Low soil water contents in the drier stands were not observed before June or July, after stand transpiration had started to deplete the soil water resources (Fig. 1a). This indicates that drought stress cannot be a critical factor during the onset of fine root growth in spring. For the same reason, leaf expansion in May was found to be not dependent on water supply in these beech stands; rather, it was dependent on temperature and possibly N-supply along the transect (see Chapter III).

Discrimination against ${ }^{13} \mathrm{C}$ during photosynthesis is a well characterised phenomenon (Farquhar et al. 1989). However, post-photosynthetic fractionation of stable carbon isotopes further modifies isotopic signatures of individual plant organs (Hobbie et al. 2002, Badeck et al. 2005, Peuke et al. 2006). In this study, leaves were on average by $1-4 \%$ lighter in terms of carbon than roots, which is probably a consequence of the post-photosynthetic carbohydrate fractionation, either during sugar transfer from leaves to roots or during root respiration (Hobbie et al. 2002, Damesin \& Lelarge 2003, Badeck et al. 2005, Peuke et al. 2006). The $\delta^{13} \mathrm{C}$-signature of fine root biomass produced hints on physiological changes that may have taken place in the droughtexposed roots of the low-precipitation stands. The large exponential increase in root $\delta^{13} \mathrm{C}$ toward the driest stands may possibly be explained by a higher carbohydrate demand of the roots in the driest stands, caused by elevated root mortality. Increased 
fine root mortality would increase competition intensity for carbon between plantinternal sinks and, thus, decrease ${ }^{13} \mathrm{C}$-discrimination during root growth.

We hypothesise that the drier stands face a higher drought-induced fine root mortality in late-summer, thereby reducing fine root biomass to lower standing stocks than in the moister stands. To compensate for these biomass losses, fine root growth seems to have increased in relative terms, since we observed a higher relative fine root ingrowth rate, i.e., a higher growth per standing stock, in the ingrowth cores of the drier stands compared to the moister ones. Thus, water shortage in summer apparently has increased the sink strength for carbon per unit of root system, even though total root biomass decreased toward the drier stands. Thus, when applied to beech root functioning during drought, the optimal partitioning theory requires a modification in the sense that drought may well increase carbon allocation to roots when soil water is limiting, but only in relative terms, while total fine root biomass and the fine root/leaf biomass ratio are reduced.

\section{Adaptive response of the beech root system to drought}

Tree fine root systems in dry climates have been found to respond to water shortage not only by a reduction in overall fine root biomass, but also by exploring deeper, moister soil layers (Richards \& Caldwell 1987, Kozlowski et al. 1991, Nepstad et al. 1994, Jackson et al. 1999). This was also observed, for example, for mesic Norway spruce and Sugar maple stands at dry sites (Persson et al. 1995, Hendrick \& Pregitzer 1996). Repeated proliferation of roots into unexplored soil patches or layers may be a more successful strategy of drought survival than the ability to extract large amounts of water in moist periods. According to our measurements, only $12 \%$ of the profile total fine root biomass of European beech occurred in the lower part of the soil profiles at $20-40 \mathrm{~cm}$ depth and only $10 \%$ at $40-120 \mathrm{~cm}$ depth. This is in accordance with the conclusions by Jackson et al. (1996) from a literature review, indicating that the fine root system of trees is mostly insignificant in terms of its biomass below $40 \mathrm{~cm}$ soil depth. However, unlike nutrient uptake, which mainly takes place in the nitrogen- and phosphorus-rich upper soil horizons, water absorption by tree roots does not only occur near the soil surface with highest fine root densities, but is also dependent on a few highly active, deep-reaching roots (Carbon et al. 1980, Nepstad et al. 1994, Bishop \& Dambrine 1995).

In the case of European beech, we found a significant shift of fine root biomass from the organic layer to the upper mineral soil with decreasing precipitation along our transect. The organic layer of the drier stands generally was thinner and more mull-like (mullmoders) than in the moister stands, where thicker, more humified leptomoders 
were present. Hydrologic measurements in drought-exposed, mull-like organic layers have shown that the soil matrix potential can reach very low values during summer, which makes these layers unfavourable for fine root growth (Leuschner, unpubl.). Thus, beech roots seem to retreat from drought-exposed organic upper soil layers in regions affected by irregular summer droughts.

Reduced water availability may also affect fine root morphology, in particular the average diameter of fine roots (or specific root surface area, SRA). According to our investigation, SRA increased significantly with decreasing precipitation in two of the three study years. Thus, a higher fine root surface area compensated partly for the smaller total fine root biomass in the drier stands. Thin roots $<1 \mathrm{~mm}$ in diameter are primarily important for water and nutrient uptake and tend to have a shorter lifespan than thicker, higher-order roots. The latter are mainly serving for transport and carbohydrate storage, and for producing additional lateral roots (Eissenstat et al. 2000, Pregitzer 2002). During extended periods of drought, the thinner roots of the uppermost dry horizons may readily be shed, hence reducing whole-plant maintenance costs when soil conditions are unfavourable (Bryla et al. 1997). Carbon invested into root maintenance often exceeds the amounts of $C$ used for root production. Therefore, such a strategy is in accordance with the optimization of carbon-use efficiency at the whole plant level (Eissenstat 1997), because roots are produced under favourable soil conditions when high amounts of water and nutrients can be extracted, but they are shed when soil resource are poor in supply, thus maximizing overall tree productivity (Eissenstat \& Yanai 2002).

\section{Conclusions}

Our transect study in 14 mature beech forests on similar geologic substrate revealed adaptive responses of the fine root system along a precipitation gradient, in particular a decrease in mean fine root diameter and an apparent change in root carbon turnover patterns (as indicated by the $\delta^{13} \mathrm{C}$-signature) with decreasing rainfall. A higher summer drought apparently increases carbon allocation to fine roots in relative, but not in absolute terms, thereby partly compensating for a substantial reduction in total fine root biomass toward the drier stands. While the optimal partitioning theory fails to explain the observed decrease in fine root biomass and fine root/leaf biomass ratio with decreasing precipitation, the theory is supported by the data if modified to account for carbon allocation, thereby considering root turnover as well. The fine root system of beech showed a considerable plasticity across the precipitation gradient, both with respect to overall size and dynamics, which is most likely one of the causes for European beech being successful in high- and low-precipitation environments. Studies 
including direct observation of root turnover with the mini-rhizotron technique and throughfall exclusion experiments in mature stands are needed to provide a more detailed understanding of the relationship between beech fine root dynamics and water availability under field conditions.

\section{Acknowledgements}

The authors would like to thank Dr. H. Meesenburg (Nordwestdeutsche Forstliche Versuchsanstalt, Göttingen) and Dr. D. Burk for the provision of data. We gratefully acknowledge the financial support granted to I.C. Meier by the Deutsche Bundesstiftung Umwelt. 


\title{
Chapter 5
}

\section{Genotypic variation and phenotypic plasticity in the drought response of the fine root system of European beech}

\author{
IC Meier $\cdot$ Ch Leuschner \\ Tree Physiology (2008) 28 297-309
}




\section{Summary}

How temperate trees will respond to drier summers under climate change as predicted for parts of Europe and eastern North America will depend to a large extent on the drought susceptibility of the root system. We investigated the importance of the genetic constitution for the belowground drought response of European beech (Fagus sylvatica L.) in an experiment with four beech populations from regions with low to high precipitation (520-970 mm yr ${ }^{-1}$ ). Saplings were grown at ample (10 vol.\%) or reduced soil moisture (5 vol.\%) in the Göttingen Rhizolab Facility for two consecutive summers, and the response of fine root biomass, root morphology, root depth distribution, fine root production and turnover was investigated by a combined mini-rhizotron and harvest technique approach. Total root mass per plant was reduced by $30-40 \%$ in the dry treatment, which resulted from (i) a reduction of median fine root lifespan by roughly $50 \%$ and hence an increase in fine root turnover, and (ii) a 10-fold reduction in relative fine root growth rate (productivity per standing root biomass). The root/shoot ratio did not increase with drought. Although beech plants originating from drier climates tended to reduce their root biomass upon drought less than those from moister origins, analyses of variance revealed no significant influence of genotype on root mass, morphology, growth rate or turnover. However, all investigated fine root traits (with few exceptions) showed considerable phenotypic plasticity between the dry and wet treatments. We conclude that beech saplings respond to summer drought primarily by shortening root lifespan, whereas root system structure and root/shoot Cpartitioning pattern are not altered. While beech fine root growth and turnover were subject to a high phenotypic plasticity, genotypic variation was of minor importance. In contrast, genotype had a strong influence on leaf and shoot morphogenesis and growth.

Keywords: common garden experiment, $\delta^{13} C$-signature, Fagus sylvatica, fine root longevity, fine root turnover, genetic variability, mini-rhizotrons, rhizolab, root morphology 


\section{Introduction}

Climate change is predicted to result in reduced summer rainfall and warmer winters in parts of Central Europe (IPCC 2001, 2007, Rowell \& Jones 2006). Plants will have to respond to these rapidly changing climatic conditions or will face local extinction if they are not sufficiently adapted to altered drought and temperature conditions. Variation within species may increase adaptability to a changing environment, and can be achieved by different means: a population can exhibit a high degree of genetic variability, comprising genotypes adapted to different environments, or a given genotype can exhibit a certain degree of phenotypic plasticity, coding for the ability of the individual to express different physiological or morphological phenotypes in different environments (Gregorius \& Kleinschmit 1999, Pigliucci 2001, Callaway et al. 2003). While phenotypic plasticity generally evolves to maximise fitness in variable environments, specialisation is favoured over plasticity in more stable environments by a variety of inherent costs to plasticity (Van Tienderen 1991, Dorn et al. 2000, Relyea 2002). The extent of phenotypic plasticity often has a genetic basis and is subject to selective pressure, and thus can be adaptive to the biotic or abiotic environment (Schlichting 1986, Jasieński et al. 1997, Agrawal 2001). It is not known whether specific genes are responsible for coding for phenotypic plasticity or if plasticity evolves as a by-product of selection for individual traits (Scheiner 1993, Schlichting \& Pigliucci 1993, Via 1993). Nonetheless, elevated levels of genetic diversity and heterozygosity are thought to increase survival capacity and adaptability (Hertel 1992, Hazler et al. 1997). Rapid climate change as predicted requires a deeper understanding of the genetic and phenotypic basis of plant adaptation to altered drought and temperature regimes.

In Central Europe, European beech (Fagus sylvatica L.) is one of the economically most important tree species. Genetic differentiation between beech stands has been found to be extremely low, whereas genetic variation within autochthonous populations is generally substantial (Comps et al. 1990, Belletti \& Lanteri 1996). Weak genetic differentiation between different beech stands as evidenced by analysis of isozyme loci (Comps et al. 1990, Gömöry et al. 1992) or cpDNA markers (Demesure et al. 1996) is predominantly explained by historical factors: after the last glacial period of the Pleistocene, European beech was one of the last European tree species to re-colonise Central Europe from its refugial areas and arrived in central Germany about 5,0004,000 yrs BP (Magri et al. 2006). Thus, no more than 20 to 50 beech generations have passed until today. A drastic reduction in population size of European beech during the last glacial period has been considered to be one of the main factors responsible for the low allelic diversity of modern beech (Comps et al. 2001). Postglacial leading edge 
expansion into new territory resulted in founding events and a further loss of alleles, while homozygosity increased (Hewitt 2000). Notwithstanding the depauperation of the beech gene pool owing to historical events, limited gene flow due to small transport distances of effective beech pollen may promote new, local genetic differentiation (Cuguen et al. 1988, Müller-Stark 1996, Wang 2001).

Despite its comparably low genetic diversity and heterozygosity, beech is an abundant late-successional tree species in Central Europe. In this area, beech is a strong competitor, achieving dominance on sites representing a relatively broad spectrum of nutrient and hydrologic regimes. Even though it grows on sites with high to relatively low rainfall, Fagus sylvatica has turned out to be more vulnerable to drought-induced cavitation and stem growth reductions upon water shortage than other temperate broad-leaved trees such as oaks (Cochard et al. 2001, Leuschner et al. 2001a). In addition, European beech may suffer from pre-senescent leaf shedding or even canopy dieback on shallow soils in the course of severe droughts (Bréda et al. 2006).

While much attention has been paid to the drought response of aboveground organs such as stems, twigs and leaves, little is known about the response of the root system of beech trees to water shortage. Although fine roots constitute only about $2-3 \%$ of the total biomass, fine root production may account for roughly $50 \%$ of the carbon cycled in forests, and can consume up to $66 \%$ of the annual photosynthate assimilated by the canopy (Nadelhoffer \& Raich 1992, Hendrick \& Pregitzer 1993, Vogt et al. 1996). Any distortion of the fine root system by stressors such as drought should therefore not only influence tree vitality, but might also affect carbon and nutrient cycling in the ecosystem.

This study used a common garden experiment in the Göttingen Rhizolab Facility to investigate the drought response of fine root production and turnover and fine root morphology in beech from four different provenances with contrasting drought experience at their origin. Study aims were (i) to compare the drought response of belowground and aboveground plant organs and (ii) to differentiate between phenotypic plasticity and genetic variability in the drought response of beech root systems. 


\section{Materials and Methods}

\section{Plant material}

Four Fagus sylvatica L. forests in the centre of the distribution range of beech in central Germany (states of Lower Saxony, Thuringia, and Saxony-Anhalt) were selected for study to represent large differences in annual precipitation. The four stands were located along a $150 \mathrm{~km}$-long WNW-ESE gradient in submontane elevation between the Solling Mountains and the Thuringian Basin. The stands were sufficiently comparable with respect to stand structure (closed canopy without major gaps) and age (100$120 \mathrm{yrs}$ ), soil chemical conditions (geological substrate: Triassic sandstone of Middle Bunter, formation 'Hardegsen Folge'), and temperature $\left(7.3\right.$ to $8.0^{\circ} \mathrm{C}$; Table 1$)$. Mean annual precipitation decreased from the west $\left(970 \mathrm{~mm} \mathrm{yr}^{-1}\right)$ to the east $\left(520 \mathrm{~mm} \mathrm{yr}^{-1}\right)$, reflecting the transition from a more sub-oceanic to a more sub-continental climate in the rain shadow of the Solling and Harz mountains. The corresponding summer rainfall (May to September) decreased from 420 to $270 \mathrm{~mm} \mathrm{yr}^{-1}$. In these stands, beech saplings grown from seeds of a natural masting event were excavated and used as experimental plants in the Rhizolab.

Table 1. Longitude, latitude, mean annual or summer precipitation, and mean annual temperature at origin, as well as harmonic mean of diversity $v$ (Gregorius 1978) and mean expected heterozygosity $\mathrm{H}_{\mathrm{e}}$ of the gene pool of four different origins of Fagus sylvatica L. used in the experiment in the Rhizolab Facility. Mean annual precipitation and temperature were derived from weather station data corrected for altitude.

\begin{tabular}{|c|c|c|c|c|c|c|c|}
\hline \multirow[t]{2}{*}{ Origin } & \multirow[t]{2}{*}{ Longitude } & \multirow[t]{2}{*}{ Latitude } & \multicolumn{2}{|c|}{$\begin{array}{l}\text { Precipitation } \\
{[\mathrm{mm}]}\end{array}$} & \multirow{2}{*}{$\begin{array}{c}\text { Temperature } \\
{\left[{ }^{\circ} \mathrm{C}\right]} \\
\text { annual } \\
\end{array}$} & \multirow[t]{2}{*}{ Diversity } & \multirow[t]{2}{*}{ Heterozygosity } \\
\hline & & & annual & summer & & & \\
\hline Ziegelroda & $11^{\circ} 25^{\prime}$ & $51^{\circ} 22^{\prime}$ & 520 & 270 & 8.0 & 1.33 & 0.27 \\
\hline Bleicherode & $10^{\circ} 27^{\prime}$ & $51^{\circ} 32^{\prime}$ & 650 & 300 & 7.8 & 1.35 & 0.28 \\
\hline Westerhofen & $10^{\circ} 02^{\prime}$ & $51^{\circ} 57^{\prime}$ & 860 & 410 & 8.2 & 1.26 & 0.22 \\
\hline Dassel & $09^{\circ} 36^{\prime}$ & $51^{\circ} 48^{\prime}$ & 970 & 420 & 7.3 & 1.30 & 0.25 \\
\hline
\end{tabular}

In April 2004, about 25 beech saplings each were selected in the stands. Selected saplings were comparable in terms of total number of leaf buds (corresponding to an age of about four yrs) and plant height (about $30 \mathrm{~cm}$ ). Selected individuals were excavated and soil material was carefully removed from the roots. Saplings were then transferred into 5 L-plastic pots filled with fertilised sand (Osmocote Pro Controlled Release Fertiliser, Substral, Austria). The pots were placed in a random arrangement in a greenhouse, where the beech saplings were cultivated at a mean daytime temperatures of $20-23^{\circ} \mathrm{C}$ and night temperatures of $12-15^{\circ} \mathrm{C}$ in well watered soil for the following four months. To adapt the small trees to the outdoor temperature regime, the 
pots were moved to the garden in August 2004, where they were sufficiently watered until transfer to the Rhizolab containers in November 2004.

\section{The Göttingen Rhizolab Facility and experimental design}

The Göttingen Rhizolab is an outdoor laboratory for the experimental study of growth dynamics of root systems of woody plants. It consists of eight drained containers $\left(1.8 \times 1.8 \times 2.2 \mathrm{~m}\right.$, for a total of $\left.7.1 \mathrm{~m}^{3}\right)$ arranged in two rows in a cellar-like subterranean setting. The containers are large enough to grow young trees under defined soil moisture and soil chemical conditions for several years without root limitation or intertree competition, while the plants are exposed to the outdoor environment. Each container is subterraneously accessible from two sides and filled with unfertilised medium-grained sand. The bulk density is comparable to that of the sandstone-derived soils at the plants' origin. The sand has a $\mathrm{pH}(\mathrm{KCl})$ of 6.7 , a $\mathrm{C} / \mathrm{N}$ ratio of 4.6 , high phosphorus content $\left(9.3 \mu \mathrm{mol} \mathrm{g}{ }^{-1}\right)$, cation exchange capacity of $41 \mu \mathrm{mol}_{\mathrm{c}} \mathrm{g}^{-1}$, and high base saturation (98\%). These values tend to mirror relatively rich conditions in natural beech forests, and thus additional fertilisation was deemed unnecessary (cf. Leuschner et al. 2006a). Twenty-four Plexiglas mini-rhizotron tubes (length $2.05 \mathrm{~m}$, diameter $7 \mathrm{~cm}$ ) are installed in the upper part of each container horizontally in rows at six defined soil depths $(15.0,30.5,46.0,61.5,92.5,123.5 \mathrm{~cm}$ from the surface, four tubes per soil depth, arranged alternately in a criss-cross fashion; a total of 192 tubes in the Rhizolab). With this dense system of observation tubes, root growth and death can be monitored with high spatial resolution in the containers. Every mini-rhizotron tube is sealed permanently at the back end with a Plexiglas disc, while the front is covered with a removable plastic cover. The protruding part of the tube is covered with lightimpermeable foil.

The Rhizolab is covered by a mobile roof that automatically covers the young trees in the case of rainfall and thus allows precise soil moisture control, but exposes the plants to the natural insolation in the absence of rain. In the experiment, two soil moisture levels were maintained: a dry (5 vol.\%) and a moist treatment (10 vol.\%; control) each replicated fourfold. Soil moisture was measured throughout the profile to a depth of $1.6 \mathrm{~m}$; to this end, five access tubes were inserted vertically per container and the volumetric soil water content measured every second day by frequency domain reflectometry (FDR; Diviner2000, Sentek sensor technologies, Australia). Water lost by transpiration or evaporation was quantified with the soil moisture data to a soil depth of $40 \mathrm{~cm}$ and replaced every day by homogeneous drip irrigation.

Air temperature and air humidity were recorded continuously at 10-min intervals with a Hobo Pro RH/Temp (Onset Computer, USA) data logger (see table 2). Soil 
temperature was measured with several NTC (negative temperature coefficient) thermistors arranged in five, horizontal lines at $10 \mathrm{~cm}$ soil depth and at two vertical profiles to a depth of $1 \mathrm{~m}$.

Table 2. Climatic conditions during the experiment in the Göttingen Rhizolab Facility in the 2005 growing season, in winter 2005/2006, and in the 2006 growing season.

\begin{tabular}{lrrrrrrrr}
\hline & & \multicolumn{2}{c}{2005} & \multicolumn{2}{c}{ 2005/2006 } & \multicolumn{2}{c}{2006} \\
& & & May-Sep & Min-Max & Oct-Apr & Min-Max & May-Sep & Min-Max \\
\hline Air temperature & & {$\left[{ }^{\circ} \mathrm{C}\right]$} & 18.5 & $(0.7-41.1)$ & 4.2 & $(-14.7-29.5)$ & 20.0 & $(1.2-44.4)$ \\
Soil temperature & $5 \mathrm{~cm}$ & {$\left[{ }^{\circ} \mathrm{C}\right]$} & 17.5 & $(5.7-34.0)$ & 4.4 & $(-7.1-27.4)$ & 19.6 & $(7.0-35.1)$ \\
& $40 \mathrm{~cm}$ & {$\left[{ }^{\circ} \mathrm{C}\right]$} & 17.5 & $(11.1-23.4)$ & 4.6 & $(-1.1-21.5)$ & 19.1 & $(10.5-26.7)$ \\
VPD & & {$[\mathrm{hPa}]$} & 7.5 & & 1.4 & & 9.0 & \\
\hline
\end{tabular}

${ }^{1}$-Soil temperature data in the 2006 growing season from May to August

In November 2004, thirty-two of the cultivated beech trees (eight per origin) were transferred to the containers of the Rhizolab. In every container, four trees (one per origin) were planted in a randomised block design at equal distances (about $1 \mathrm{~m}$ ) to each other. The treatments were replicated fourfold in different randomly arranged containers in the Rhizolab (four dry and four moist containers each containing four trees). The drought treatment was initiated at the end of May 2005 at the termination of the first period of leaf expansion and was continued until August 2006. In the cold season (October 2005 - April 2006) the Rhizolab was left uncovered to allow for natural precipitation allowing for a re-saturation of the soil water reserves. The experiment thus simulated two summer drought periods of $16-18$ wks subsequent to the first phase of leaf growth, such as may occur in very dry years in central Germany.

\section{Analysis of isozyme systems}

To characterise genetic differences between the four investigated beech populations, isozyme analyses of ten enzymes were carried out (ISOGEN, Reckershausen, Germany). Dormant buds were sampled at the end of the experiment in August 2006, analysed for isozymes of isocitrate dehydrogenase (IDH-A), malate dehydrogenase $(\mathrm{MDH}-\mathrm{B}, \mathrm{MDH}-\mathrm{C})$, 6-phosphogluconate dehydrogenase (6-PGDH), shikimate dehydrogenase (SKDH-A), glutamate oxaloacetate transaminase (GOT-B), phosphoglucomutase (PGM-A), phosphoglucose isomerase (PGI-A, PGI-B), and menadione reductase (MNR-A) by standard techniques (Cheliak \& Pitel 1984, Liengsiri et al. 1990). The genetic diversity (v), expected heterozygosity $\left(H_{e}\right)$, and a comparison between the genetic structures of the populations according to the genetic distance $\left(d_{0}\right)$ 
were calculated with the program GSED (Gillet 1994). By definition, genetic distance $d_{0}$ (Gregorius 1974) was $0 \%$ if the genetic structures were identical and $d_{0}$ was $100 \%$ if they were completely different.

\section{Mini-rhizotron image recording and root growth analysis}

For quantifying root growth and death, mini-rhizotron images of the roots were collected with a scanner system (CI-600, CID Inc., USA). Pictures were recorded every second week at the entire surface of the mini-rhizotron tubes from May 2005 to August 2006 (or every fourth week in the cold season from October 2005 to April 2006). Because of the spatial arrangement of the beech individuals in the containers (plant distance $1 \mathrm{~m}$ ), roots observed at the tube surface could in nearly all cases be assigned to a certain plant. In order to determine temporal changes in root length, image sequences were analysed with the computer program WinRHIZOTron (Régent Instruments, Quebec, Canada). Root order as defined by Pregitzer et al. (2002) was determined visually. Since the determination of root vitality based on colour has proved to be difficult or even impossible (Comas et al. 2000, Withington et al. 2006), we used the date of disappearance of a root segment as the date of its death. In most cases, root periderm or cortex exhibited no signs of vitality loss before the root disappeared. Hence, our approach to root lifespan determination, which uses the period between appearance and disappearance, will overestimate root longevity, because any reduction in root vitality prior to death is ignored. Root lifespan and root persistence are accordingly used as synonyms in this study. In order to calculate with precise dates, root birth and death events were assumed to have occurred in the middle between two successive imaging dates. Individual root life span was calculated as the number of days from root birth to root death. Root survivorship curves were then calculated from the recorded birth and death events or from the birth events and the time until the end of the experiment using the Weibull distribution for right-censored data with the package SAS, version 8.2 (Cary, USA). This was done for the root cohort born in the cold season until the beginning of the second experimental drought treatment, i.e., in the period from October 2005 to May 2006.

Relative production of fine roots was defined as the sum of fine root length increase in the 2006 growing season related to the existing fine root length in April 2006. Since a non-steady state situation of root growth and death in the containers of the Rhizolab was presumed, turnover of fine roots was calculated as the sum of fine root length decrease in the 2006 growing season relative to the sum of fine root length increase in this period. 


\section{Measurement of biomass production and root and shoot morphology}

The young beech trees were harvested in mid-August 2006. After carefully extracting the complete trees from the soil, the remaining soil material was washed off the roots and maximum rooting width and depth in the containers were determined. The trees were then separated into above-ground and below-ground biomass. Roots were sorted by diameter (fine roots $<2 \mathrm{~mm}$, coarse roots $>2 \mathrm{~mm}$ ) and the root system sliced into $10 \mathrm{~cm}$-depth layers. Total fine root surface area and specific root area (SRA, in $\mathrm{cm}^{2} \mathrm{~g}^{-1}$ ) were determined in each four randomly selected, intact branch root systems $(10-15 \mathrm{~cm}$ in length) per layer. Leaf size and specific leaf area (SLA, in $\left.\mathrm{cm}^{2} \mathrm{~g}^{-1}\right)$ were determined for all leaves of a tree. Root and leaf area measurements were conducted by optical surface measurement with a flat-bed scanner using the programs WinRHIZO and WinFOLIA, respectively (Régent Instruments, Quebec, Canada). After analysis, leaves, shoots, coarse roots, and fine roots were dried $\left(48 \mathrm{~h}, 70^{\circ} \mathrm{C}\right)$ and weighed. Dried samples were grounded and analysed for total carbon and nitrogen with a $\mathrm{C} / \mathrm{N}$ elemental analyser. The carbon isotope signature of plant dry mass was analysed by mass spectroscopy (Delta plus, ThermoFinnigan, USA) in the Centre for Stable Isotope Research and Analysis (KOSI) of the University of Göttingen.

\section{Statistical analyses}

Statistical analyses were conducted with the package SAS, version 8.2 (SAS Institute, Cary, USA). Means and standard errors of root traits were calculated from each four beech trees per treatment and origin. Probability of fit to normal distribution was tested with a Shapiro-Wilk test $(p \leq 0.05)$. Those data sets deviating from normal distribution were compared by one-way Kruskal-Wallis single factor analyses of variance and nonparametric multiple comparison tests after Wilcoxon to locate the differences. In case of Gaussian distribution, means of each treatment and origin were compared with onefactorial analyses of variance followed by a Scheffé test to analyse the differences between treatments and origins in detail. Additionally, means of treatments and origins were subjected to two-factorial analyses of variance to assess the importance of the influence of genotype (genetic variability) or treatment (phenotypic plasticity) or their interaction on various root properties. A plasticity index was calculated as $\mathrm{PI}=$ (maximum median - minimum median)/maximum median (according to Valladares et al. 2006). We applied linear regression analyses to quantify the influence of the precipitation at the origin of a population on various root characteristics in the experiment. We used a lower significance level of $p \leq 0.1$ in all tests, because it turned out that fine root biomass and turnover were highly variable among the plants and treatments, while it was impossible to accommodate more than four replicate containers per treatment with sufficient mini-rhizotron equipment and associated image analysis. Hence, our statistical tests indicate only weak significance in most cases. 


\section{Results}

\section{Genetic differences between the beech populations}

On the basis of the isozyme analyses, the four investigated beech provenances turned out to be comparable with respect to their mean diversity $\vee(1.26-1.35)$ and expected heterozygosity $\mathrm{H}_{\mathrm{e}}(0.22-0.28)$ within the gene pool of the population (Table 1). The genetic distance $d_{0}$ between the gene pools made the four beech populations clearly distinguishable from each other (Table 3).

Table 3. Genetic distances ( $d_{0}$ in $\%$ ) between the genetic structures of the four different beech populations

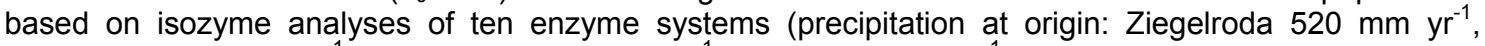
Bleicherode $650 \mathrm{~mm} \mathrm{yr}^{-1}$, Westerhofen $860 \mathrm{~mm} \mathrm{yr}^{-1}$, Dassel $970 \mathrm{~mm} \mathrm{yr}^{-1}$ ).

\begin{tabular}{lcccc}
\hline Origins & Ziegelroda & Bleicherode & Westerhofen & Dassel \\
\hline Ziegelroda & 0.0 & & & \\
Bleicherode & 13.7 & 0.0 & & \\
Westerhofen & 8.1 & 15.0 & 0.0 & \\
Dassel & 8.7 & 13.7 & 5.0 & 0.0 \\
\hline
\end{tabular}

Although the genetic distance between the wet and the moderately wet tree origin was only $5 \%$, the two origins had a genetic distance of $8-9 \%$ to the population of the driest stand and of $14-15 \%$ to the moderately dry site. The trees from the moderately dry tree provenance (Bleicherode) were the most distant from the other genotypes.

\section{Drought effects on fine root biomass and its vertical distribution}

After 20 months of growth in the rhizolab containers, the young beech trees had 24 to $52 \mathrm{~g}$ of total root biomass per tree, or 12 to $28 \mathrm{~g}$ of fine root biomass (Fig. 1a) with no significant difference between the populations from dry or wet sites. However, the four populations responded differently to the drought treatment, which was applied for 16 to 18 wks in summer 2005 and 2006. Fine root biomass was reduced by $41 \%$ in the beech individuals from sites with high or moderately high precipitation (difference between treatments significant), but by only $29 \%$ in the trees from areas with low or moderately low annual precipitation (difference not significant). Thus, beech trees originating from sites with ample water supply showed a more pronounced relative reduction of their fine root biomass in response to soil drought than those originating from drier sites. 

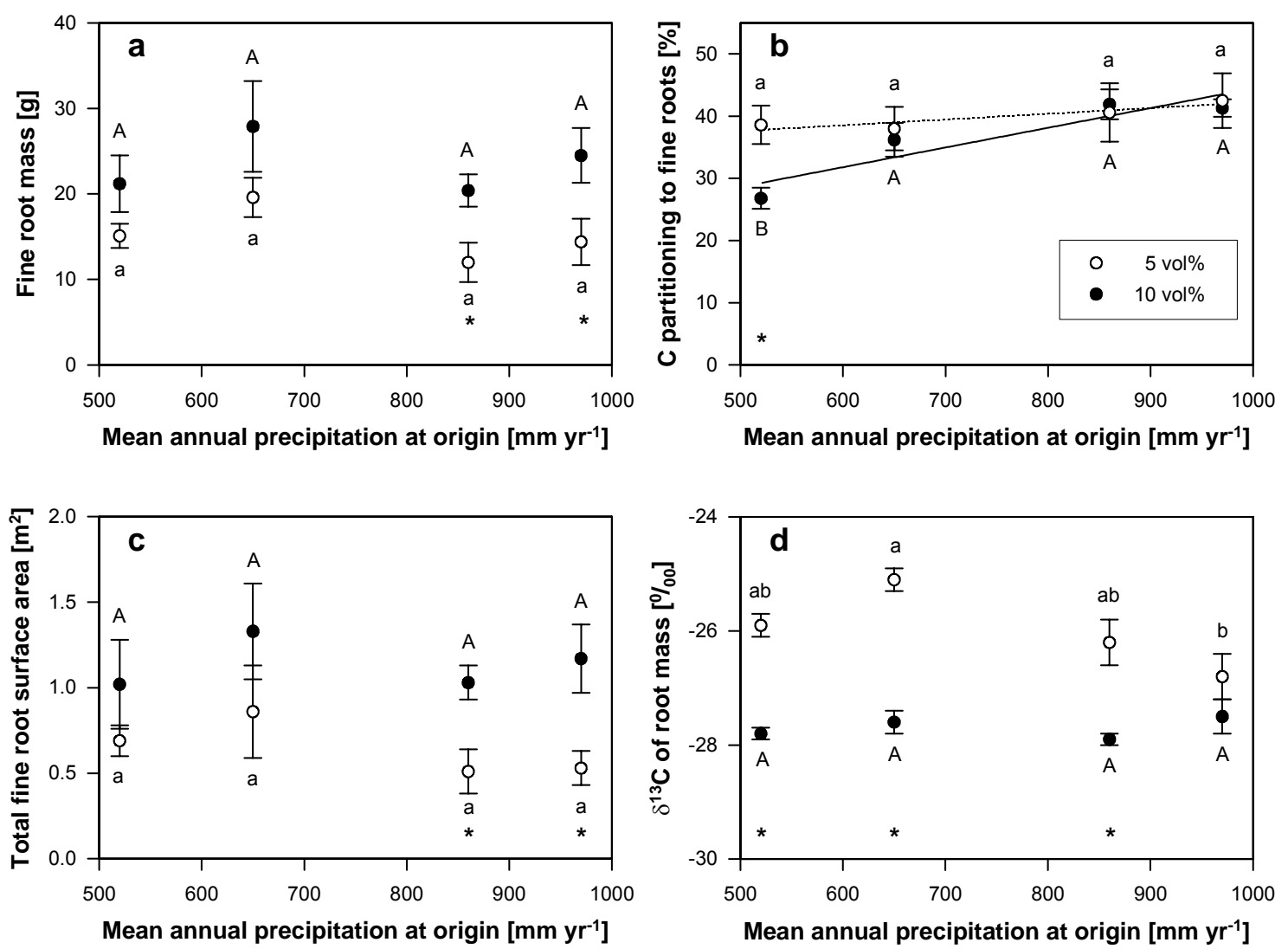

Figure 1a-d. Relationship between mean annual precipitation at plant origin and fine root mass at the date of harvest, total fine root surface area, relative carbon allocation to fine roots and $\delta^{13} \mathrm{C}$-signature in fine root dry mass of four different beech populations grown at two soil moisture levels (mean and standard error of four beech trees per origin and treatment). Significant differences between origins are indicated for high soil moisture by different capital letters and for low soil moisture by different lower case letters; differences significant at $p \leq 0.1$ between the treatments are marked with *. For correlation coefficients and probabilities of error see table 5 .

All beech trees concentrated $50 \%$ or more of their fine root biomass in the uppermost $30 \mathrm{~cm}$ of the soil profile (Fig. 2). In the two wetter tree provenances (970 and $860 \mathrm{~mm}$ of annual rainfall), fine root biomass decreased exponentially with soil depth, while in the two drier provenances, fine root biomass was more evenly distributed to a depth of $40 \mathrm{~cm}$, and decreased exponentially from $40 \mathrm{~cm}$ onwards. The plants in the moist treatment not only produced more fine root biomass, but also penetrated the soil to a greater depth. In this treatment, $90 \%$ of root biomass was distributed between $0 \mathrm{~cm}$ and 50-75 $\mathrm{cm}$ depth. Beech trees from Dassel, the wettest site, had the deepest fine root penetration, while trees from the other three sites were rather similar with respect to their rooting depth. In contrast, in the dry treatment, $90 \%$ of the root biomass was distributed between $0 \mathrm{~cm}$ and $30-60 \mathrm{~cm}$ depth. The drought treatment led to a reduction of $40 \mathrm{~cm}$ in rooting depth in beech trees from the wettest site $\left(970 \mathrm{~mm} \mathrm{yr}^{-1}\right)$, but to a reduction of only $10 \mathrm{~cm}$ in individuals from the two dry sites (520 and $\left.650 \mathrm{~mm} \mathrm{yr}^{-1}\right)$. 

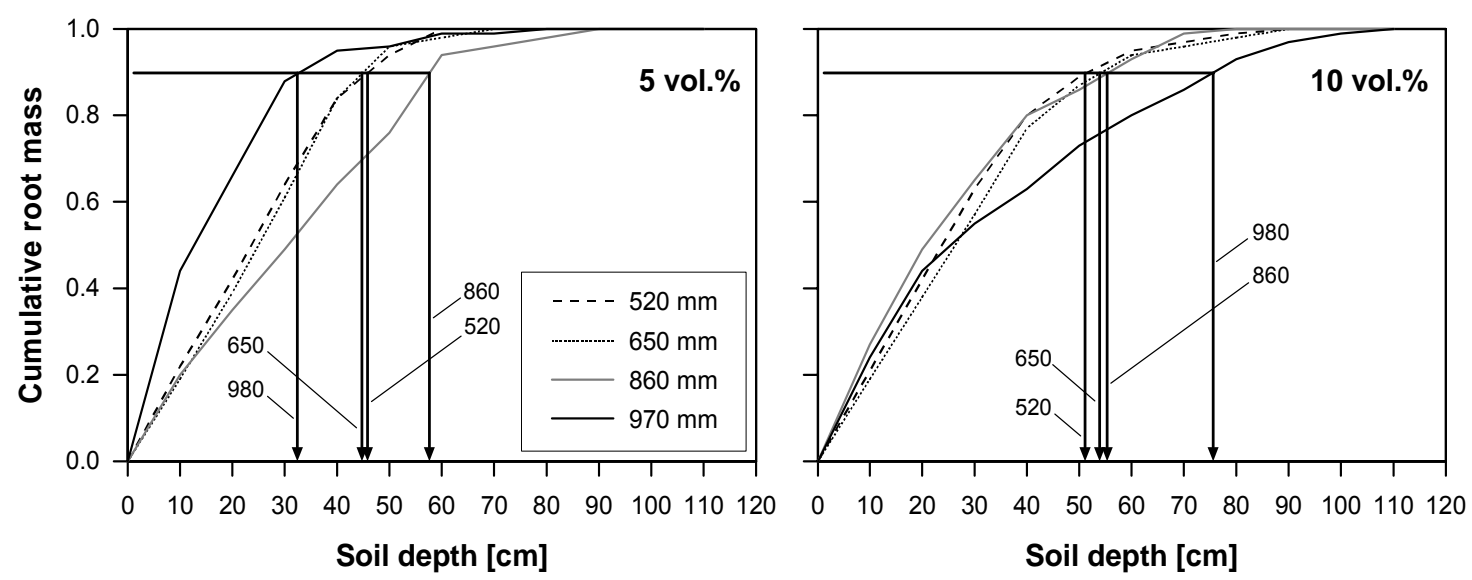

Figure 2. Cumulative root mass in the soil profile (fraction of profile total) of the four beech populations grown at two soil moisture levels (mean of four beech trees per origin and treatment). The arrows indicate the depth above which $90 \%$ of the root mass is found.

\section{Carbon partitioning to roots and $\delta^{13} \mathrm{C}$-signature of fine root mass}

On the date of harvest, $30-40 \%$ of the carbon of the young beech trees was contained in fine root biomass, while $30 \%$ was in coarse root mass. Thus, the belowground/aboveground mass ratio was roughly 1.9 , with only about $20 \%$ of total carbon located in stems and $10 \%$ in leaves.

Whereas the differences between the four populations were not significant for the absolute amount of fine root biomass, a significant impact of the rainfall amount at the origin was observed with respect to the relative carbon allocation to fine roots. In individuals from the driest site $\left(520 \mathrm{~mm} \mathrm{yr}^{-1}\right)$, C-partitioning to fine roots increased from $27 \%$ in the moist treatment to $39 \%$ in the dry treatment, indicating a drought-induced allocation shift to fine root growth in this population (Fig. 1b). In individuals from the three other sites, no significant alteration of carbon partitioning between fine roots and other organs was found with drought.

The $\delta^{13} \mathrm{C}$-signature of fine root biomass varied between $-27.9 \%$ and $-25.1 \%$ in the beech trees from the four different sites (Fig. $1 \mathrm{~d}$ ). The ${ }^{13} \mathrm{C} /{ }^{12} \mathrm{C}$ ratio was fairly constant for trees in the moist treatment $(-27.9 \%$ to $-27.5 \%)$. In the dry treatment, however, $\delta^{13} \mathrm{C}$ of root biomass significantly increased to values between $-26.8 \%$ and $-25.1 \%$. This increase was more pronounced in the beech trees from drier origins (520 and $650 \mathrm{~mm} \mathrm{yr}^{-1}$ ). 
Table 4. Root morphological characteristics of four different beech populations grown at two soil moisture levels (origin: $\mathrm{Zi}=\mathrm{Ziegelroda}, \mathrm{BI}=\mathrm{Bleicherode}, \mathrm{We}=\mathrm{Westerhofen}, \mathrm{Da}=$

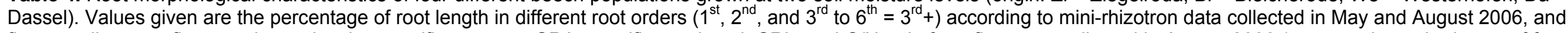
fine root diameter, fine root tissue density, specific root area SRA, specific root length SRL, and C/N ratio from fine roots collected in August 2006 (mean and standard error of four beech trees per origin and treatment). Differences between origins were not significant. Significant differences at $p \leq 0.1$ between the treatments are indicated by *.

\begin{tabular}{|c|c|c|c|c|c|c|c|c|c|c|c|c|}
\hline \multirow{2}{*}{\multicolumn{2}{|c|}{$\begin{array}{r}\text { Precipitation } \\
\text { at origin } \\
{\left[\mathrm{mm} \mathrm{yr}^{-1}\right]}\end{array}$}} & \multicolumn{6}{|c|}{ Root order [\%] } & \multirow{2}{*}{\multicolumn{2}{|c|}{$\begin{array}{c}\text { Tissue } \\
\text { density } \\
{\left[\mathrm{mg} \mathrm{cm}^{-3}\right]}\end{array}$}} & \multirow[b]{2}{*}{$\begin{array}{c}\text { SRA } \\
{\left[\mathrm{cm}^{2} \mathrm{~g}^{-1}\right]}\end{array}$} & \multirow[b]{2}{*}{$\begin{array}{c}\text { SRL } \\
{\left[\mathrm{m} \mathrm{g}^{-1}\right]}\end{array}$} & \multirow[b]{2}{*}{$\begin{array}{c}\text { C/N ratio } \\
{\left[\mathrm{mol} \mathrm{mol}{ }^{-1}\right]}\end{array}$} \\
\hline & & \multicolumn{3}{|c|}{ May } & \multicolumn{3}{|c|}{ August } & & & & & \\
\hline \multicolumn{13}{|c|}{5 vol.\% } \\
\hline $\mathrm{BI}$ & 650 & $72(9)$ & $24(5)$ & $4(3)$ & $73(9)$ & $25(8)$ & $2(1)$ & $1.36(0.16)$ & $58.3(19.4)$ & 429 (137) & $19.8(3.1)$ & $10.98(0.07)$ \\
\hline We & 860 & $68(9)$ & $32(7)$ & $0(0)$ & $78(7)$ & $20(5)$ & $2(1)$ & $1.25(0.03)^{*}$ & $42.6 \quad(4.6)$ & $380(53)$ & $19.4(2.5)$ & $10.83(0.10)^{*}$ \\
\hline $\mathrm{Da}$ & 970 & $84(4)$ & $16(2)$ & $0(0)$ & $77(6)$ & $21(5)$ & $2(1)$ & $1.19(0.15)$ & $49.0 \quad(7.4)$ & $320(47)^{*}$ & $19.3(4.5)$ & $10.70(0.28)$ \\
\hline \multicolumn{13}{|c|}{10 vol.\% } \\
\hline $\mathbf{Z i}$ & 520 & 87 (3) & $13(3)$ & $0(0)$ & $84(2)$ & $14(2)$ & $2(0)$ & $1.40(0.36)$ & $40.4 \quad(5.2)$ & 521 & $27.7(5.2)$ & $10.79(0.06)$ \\
\hline Bl & 650 & 79 (4) & $21(4)$ & 1 (1) & $87(1)$ & $12(1)$ & $1(0)$ & $1.39(0.11)$ & 55.1 & 439 (17) & $20.6(2.1)$ & $10.62(0.22)$ \\
\hline We & 860 & 79 (4) & $20(3)$ & 1 (1) & $83(1)$ & $14(0)$ & $2(1)$ & $1.58(0.11)$ & 39.9 & 421 & $19.3(3.0)$ & $10.34(0.15)$ \\
\hline $\mathrm{Da}$ & 970 & 88 & $11(5)$ & 1 (1) & $84(3)$ & $14(3)$ & $2(0)$ & $1.41(0.13)$ & $47.5(16.4)$ & 515 & $22.5(3.0)$ & $10.51(0.08)$ \\
\hline
\end{tabular}




\section{Drought effects on fine root morphology}

A significant treatment effect on fine root morphology could not be observed, although trees in the dry treatment tended to have a lower specific root area (SRA), a smaller root diameter, a lower specific root length $(S R L)$, and a higher tissue density compared to the trees in the moist treatment (Table 4). While the treatment effect was not significant, the precipitation regime at origin had a significant effect on the specific root area of beech trees in the dry treatment (Table 5): SRA decreased with increasing rainfall at origin from 431 to $320 \mathrm{~cm}^{2} \mathrm{~g}^{-1}$. Similarly, the origin had a significant influence on the specific root length of beech trees in the dry treatment: SRL decreased with increasing rainfall at origin from 24.1 to $19.3 \mathrm{~m} \mathrm{~g}^{-1}$. Thus, in response to drought, trees from the drier origins invested less biomass into a unit of fine root surface area or length than those from the wetter origins. Origin had no significant impact on diameter or tissue density of fine roots.

Table 5. Results of correlation analyses between mean annual precipitation at origin and various parameters of fine root morphology, fine root mass and production, fine root turnover, and nutrient content in fine root mass at two soil moisture levels. Values given are the Pearson correlation coefficient $r$ and the probability of error $p$. All correlations significant at $p \leq 0.1$ are in bold.

\begin{tabular}{|c|c|c|c|c|}
\hline \multirow[b]{3}{*}{ Parameter } & \multicolumn{4}{|c|}{ Soil moisture level } \\
\hline & \multicolumn{2}{|c|}{5 vol. $\%$} & \multicolumn{2}{|c|}{10 vol.\% } \\
\hline & $\mathbf{r}$ & $\mathbf{p}$ & $\mathbf{r}$ & $\mathbf{p}$ \\
\hline Specific root area (SRA) & -0.94 & 0.03 & -0.14 & 0.43 \\
\hline Fine root diameter & -0.02 & 0.49 & 0.42 & 0.29 \\
\hline Fine root tissue density & -0.37 & 0.31 & 0.01 & 0.49 \\
\hline Specific root length (SRL) & -0.81 & 0.09 & -0.60 & 0.20 \\
\hline Fine root mass & -0.49 & 0.24 & -0.01 & 0.49 \\
\hline Relative fine root production & 0.99 & 0.003 & 0.34 & 0.33 \\
\hline Fine root turnover & -0.76 & 0.12 & 0.63 & 0.19 \\
\hline Total fine root area & -0.74 & 0.13 & 0.05 & 0.48 \\
\hline C-partitioning to fine roots & 0.91 & 0.04 & 0.92 & 0.04 \\
\hline$\delta^{13} \mathrm{C}$-signature in fine roots & -0.71 & 0.14 & 0.24 & 0.37 \\
\hline $\mathrm{N}$-content in fine roots & -0.92 & 0.04 & -0.45 & 0.23 \\
\hline $\mathrm{C} / \mathrm{N}$ ratio in fine roots & -0.45 & 0.22 & -0.82 & 0.09 \\
\hline
\end{tabular}




\section{Fine root dynamics and longevity of individual roots}

The first fine root observations were made in the beginning of the growing season in May 2005, i.e., six months after the planting of the beech trees. Even though root growth and death may not have reached a steady-state in the first half of the summer of 2005, our data clearly indicate a peak in root length increase in August and September 2005 in both treatments and a decline in growth almost to zero in the leafless cold months between November 2005 and April 2006 (Fig. 3). With buds breaking and rapid leaf flushing in mid-April 2006, fine root length growth commenced in both treatments. In the moist treatment, length production almost constantly increased from April to August 2006. In contrast, in the dry treatment, length growth showed an only moderate increase or even a decrease from mid-summer (July 2006) onwards. Fine root length mortality amounted only to one third of the corresponding root length production. In the dry treatment, mortality followed mainly the same time course as productivity, while in the wet treatment, length mortality occurred almost constantly throughout the year.
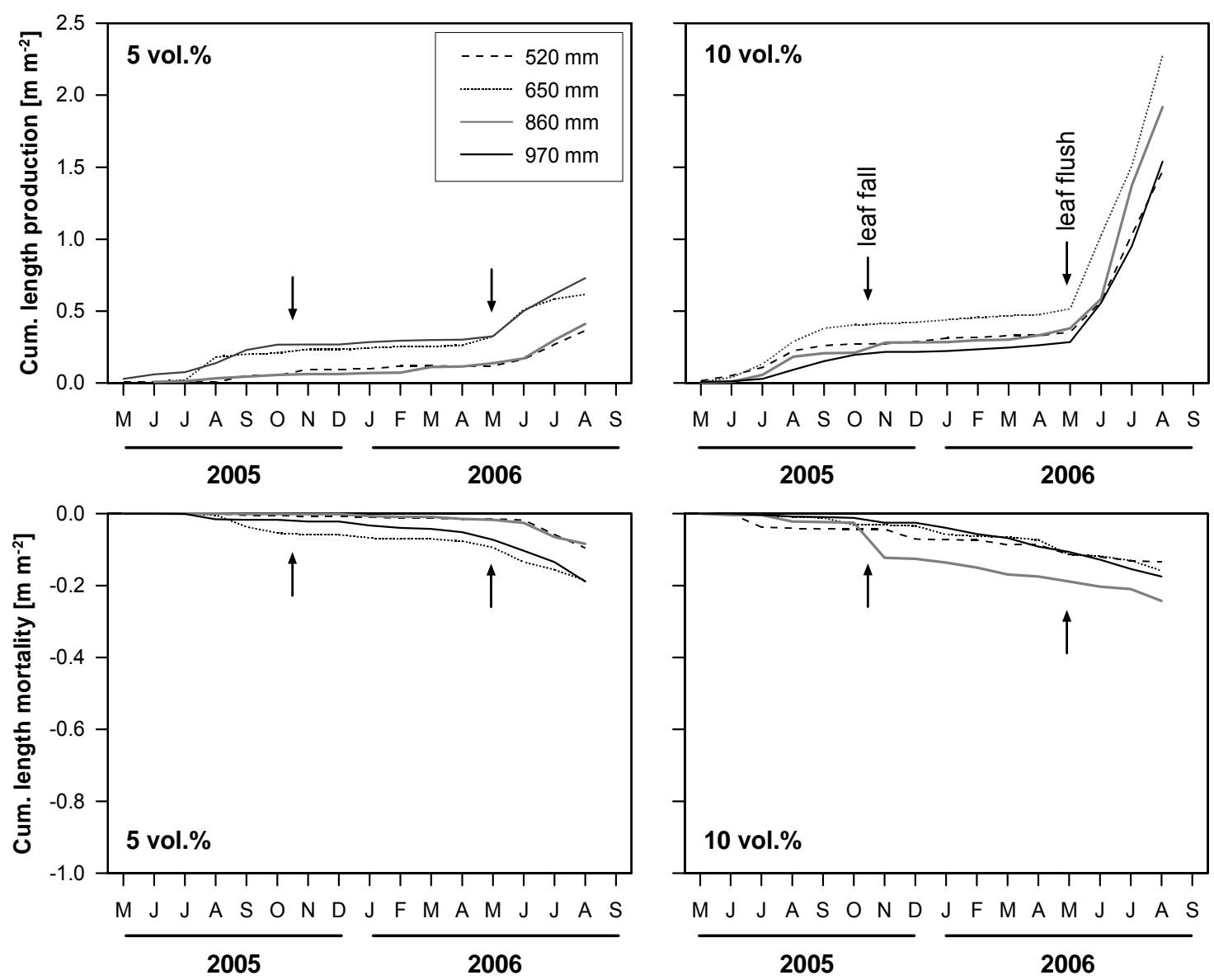

Figure 3. Cumulative length production and cumulative length mortality between May 2005 and August 2006 of fine roots of the four beech populations grown at two soil moisture levels from May 2005 to August 2006 (mean of four beech trees per origin and treatment). The arrows indicate the onset of leaf fall in autumn and leaf flush in spring. The average diameter of these roots was $0.02 \mathrm{~mm}(0.01-0.2 \mathrm{~mm}$ class). Note different scaling of $y$-axes for production and mortality. 
Table 6. Mean and standard error of root/shoot ratio, relative fine root length production (cumulative fine root length increase from May to August 2006 in relation to total root length in April 2006), fine root growth rate at 15.0 and $30.5 \mathrm{~cm}$ soil depth (at the end of the experiment in August 2006), and of root turnover in the period May to August 2006, as well as median and standard error of root life span in 2005/2006, and leaf life span in 2005 of the four different beech populations grown at two soil moisture levels (each four beech trees per origin and treatment). Significant differences at $p \leq 0.1$ between origins are indicated for high soil moisture by different capital letters and for low soil moisture by different lower case letters.

\begin{tabular}{|c|c|c|c|c|c|c|}
\hline $\begin{array}{l}\text { Precipitation } \\
\text { at origin }\end{array}$ & {$\left[\mathrm{mm} \mathrm{yr}^{-1}\right]$} & & $\begin{array}{c}\text { Ziegelroda } \\
520\end{array}$ & $\begin{array}{l}\text { Bleicherode } \\
650\end{array}$ & $\begin{array}{c}\text { Westerhofen } \\
860\end{array}$ & $\begin{array}{c}\text { Dassel } \\
970\end{array}$ \\
\hline \multirow{2}{*}{$\begin{array}{l}\text { Root/shoot } \\
\text { ratio }\end{array}$} & & 5 vol. $\%$ & $1.9^{\mathrm{a}}(0.1)$ & $1.7^{\mathrm{a}}(0.2)$ & $1.9^{\mathrm{a}}(0.2)$ & $2.3^{\mathrm{a}}(0.1)$ \\
\hline & & 10 vol. $\%$ & $1.8^{\mathrm{AB}}(0.2)$ & $1.5^{\mathrm{B}}(0.1)$ & $2.3^{A}(0.2)$ & $2.2^{\mathrm{A}}(0.2)$ \\
\hline \multirow{2}{*}{$\begin{array}{l}\text { Relative } \\
\text { fine root } \\
\text { production }\end{array}$} & & 5 vol.\% & $126^{\mathrm{b}}(110)$ & $218^{\mathrm{ab}}(131)$ & $488^{\mathrm{a}}(162)$ & $559^{\mathrm{a}}(245)$ \\
\hline & [\%] & 10 vol.\% & $6093^{A}(5211)$ & $1459^{\mathrm{A}}$ & $3840^{\mathrm{A}}(2304)$ & $7683^{A}(7080)$ \\
\hline \multirow{2}{*}{$\begin{array}{l}\text { Fine root } \\
\text { growth at } \\
15.0 \mathrm{~cm}\end{array}$} & & 5 vol.\% & $5.1^{\mathrm{ab}}(3.6)$ & $3.8^{\mathrm{b}}(1.8)$ & $9.7^{\mathrm{a}}(2.9)$ & $5.4^{\mathrm{ab}}(3.1)$ \\
\hline & {$\left[\mathrm{mm} \mathrm{d}^{-1}\right]$} & 10 vol.\% & $45.1^{\mathrm{A}}(26.7)$ & $52.9^{A}(13.7)$ & $65.8^{\mathrm{A}}(23.1)$ & $62.7^{\mathrm{A}}(10.8)$ \\
\hline \multirow{2}{*}{$\begin{array}{l}\text { Fine root } \\
\text { growth at } \\
30.5 \mathrm{~cm}\end{array}$} & & 5 vol.\% & $17.4^{\mathrm{a}}(6.0)$ & $5.2^{\mathrm{b}}(2.9)$ & $9.2^{\mathrm{ab}}(3.5)$ & $7.5^{\mathrm{ab}}(4.2)$ \\
\hline & {$\left[\mathrm{mm} \mathrm{d}^{-1}\right]$} & 10 vol.\% & $33.5^{\mathrm{A}}(13.4)$ & $73.8^{\mathrm{A}}(39.6)$ & $31.1^{\mathrm{A}}(14.1)$ & $33.5^{\mathrm{A}}(15.3)$ \\
\hline \multirow{2}{*}{$\begin{array}{l}\text { Fine root } \\
\text { turnover }\end{array}$} & & 5 vol.\% & $0.56^{\mathrm{ab}}(0.39)$ & $0.66^{\mathrm{a}}(0.43)$ & $0.09^{\mathrm{b}}(0.05)$ & $0.30^{\mathrm{ab}}(0.14)$ \\
\hline & {$\left[\mathrm{m} \mathrm{m}^{-1}\right]$} & 10 vol.\% & $0.02^{\mathrm{A}}(0.01)$ & $0.04^{\mathrm{A}}(0.03)$ & $0.02^{\mathrm{A}}(0.01)$ & $0.07^{\mathrm{A}}(0.02)$ \\
\hline \multirow{2}{*}{$\begin{array}{l}\text { Median } \\
\text { root } \\
\text { life span }\end{array}$} & & 5 vol.\% & $221(20)$ & 479 (108) & 222 & $405(57)$ \\
\hline & [d] & 10 vol.\% & $481(112)$ & 1095 & 386 (105) & $383(60)$ \\
\hline \multirow{2}{*}{$\begin{array}{l}\text { Leaf life } \\
\text { span }\end{array}$} & & 5 vol.\% & $219(5)$ & $232(1)$ & $226(5)$ & $231(6)$ \\
\hline & [d] & 10 vol.\% & $219(2)$ & $231(2)$ & $218(4)$ & $220(4)$ \\
\hline
\end{tabular}
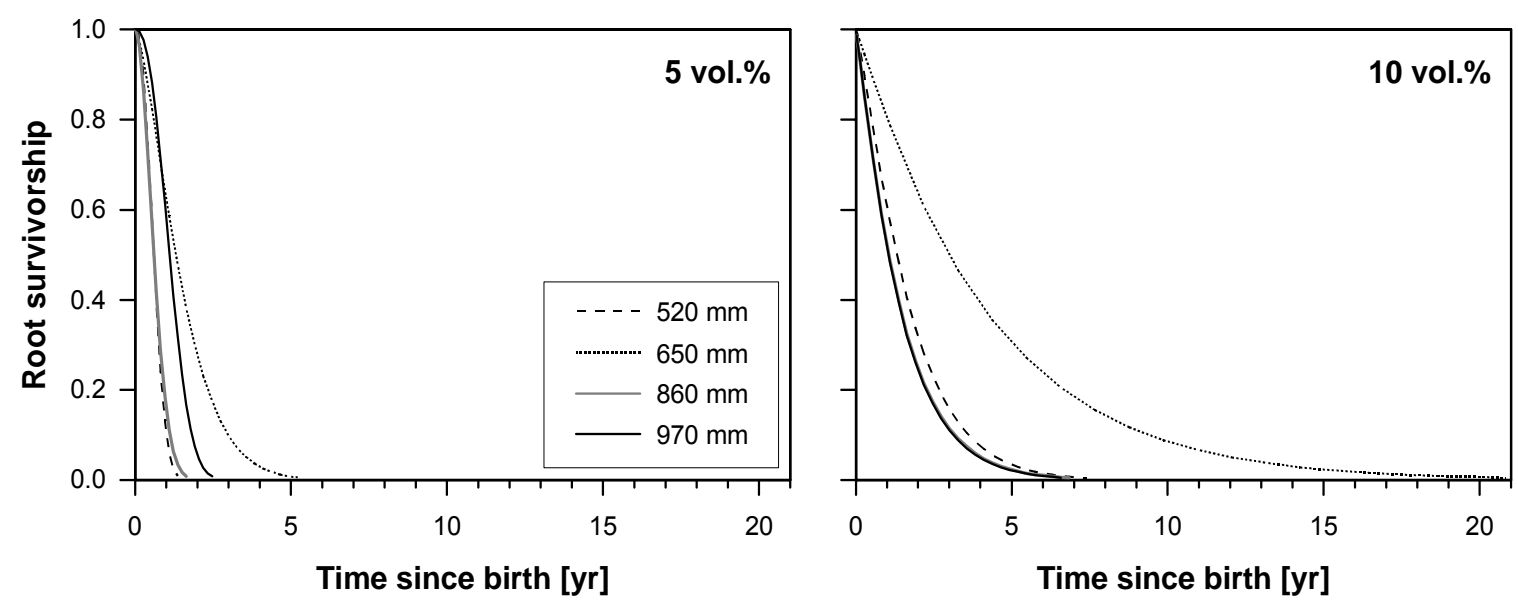

Figure 4. Root survivorship curves from mini-rhizotron data of the four beech populations grown at two soil moisture levels (mean of four beech trees per origin and treatment). Root birth and death events were assumed to have occurred in the middle between two successive biweekly sampling dates. Root survivorship curves were calculated from the presence/absence data using the Weibull distribution for right-censored data. 
In relation to the standing root length at the beginning of the 2006 growing season, fine root length increased 1.3-fold to 5.6-fold between May and August 2006 in the dry treatment, whereas it increased 14.6-fold to even 77-fold in the wet treatment (Table 6). Precipitation at the origin had a significant effect on root length production in the dry treatment, as relative root production increased with increasing rainfall at the origin of the trees. In the dry treatment, fine root growth rate was up to three times higher in deeper soil layers than near the soil surface. In the moist treatment, by contrast, fine roots grew most rapidly in the uppermost soil layer. Averaged over all four populations, mean turnover of fine roots in the period from May to August 2006 was $0.04 \mathrm{~m} \mathrm{~m}^{-1}$ in the moist treatment and higher by a factor of ten in the dry treatment $\left(0.40 \mathrm{~m} \mathrm{~m}^{-1}\right)$. Comparing the four populations showed that differences in turnover rate were less pronounced in the wet treatment than in the dry treatment, where the trees of the two dry origins had a much higher root turnover $\left(0.56\right.$ to $\left.0.66 \mathrm{~m} \mathrm{~m}^{-1}\right)$ than the moister origins $\left(0.09\right.$ to $\left.0.30 \mathrm{~m} \mathrm{~m}^{-1}\right)$.

The drought treatment reduced median root life span by nearly $50 \%$ from 1.6 yrs to only 0.9 yrs (Table 6). The longest median root lifespan (1095 d) was observed in trees from the moderately dry origin $\left(650 \mathrm{~mm} \mathrm{yr}^{-1}\right)$ in the moist treatment, even exceeding the duration of the experiment. Short-lived roots (221 d) were found in trees from the dry and the moderately wet origin (520 and $860 \mathrm{~mm} \mathrm{yr}^{-1}$ ) in the dry treatment. Drought reduced median fine root longevity by about $55 \%$ in the trees from the dry and moderately dry origins (520 and $650 \mathrm{~mm} \mathrm{yr}^{-1}$ ) and by $42 \%$ in the trees of moderately wet origin $(860 \mathrm{~mm})$, but longevity increased by about $6 \%$ in the trees from the wettest origin $(970 \mathrm{~mm})$.

\section{Discussion}

\section{The Göttingen Rhizolab as a tool of experimental root research}

The Göttingen Rhizolab facility is a system of large containers with the option to monitor root dynamics while growing woody plants under controlled hydrologic and soil chemical conditions. This laboratory combines the design of a rhizotron with the use of horizontally installed mini-rhizotron tubes for root observation. The horizontal orientation of the tubes minimises the threat of root growth artefacts due to higher soil moisture from water percolation along vertically oriented tubes as is often observed in field studies. Major advantages of this facility over an in situ investigation with minirhizotrons in the field are the well defined soil conditions, specifically of soil moisture, thereby mostly excluding confounding factors, which facilitates statistical analysis of the data. On the other hand, the more or less homogeneous soil in the containers deviates 
from field conditions by excluding vertical gradients in soil properties and a patchy distribution of nutrients, which is characteristic for most forest soils. Furthermore, the complexity of the rhizosphere with its manifold multitrophic interactions is largely reduced. Clearly, these limitations restrict the applicability of our results to the field.

\section{Drought effects on fine root biomass}

Beech saplings produced $30-40 \%$ less fine root biomass when exposed to a long summer drought (16-18 wks) in the Rhizolab experiment, while root/shoot ratio remained more or less constant (Table 6). Other drought experiments with temperate tree saplings or seedlings grown in pots or containers also showed substantial reductions in fine root biomass, but the root/shoot ratio typically increased (e.g., Bongarten \& Teskey 1987, Pallardy \& Rhoads 1993, Aspelmeier \& Leuschner 2006). Adult beech trees were also found to reduce their fine root biomass when exposed to summer drought. This is evidenced by a comparative study along a precipitation gradient in central Germany (refer to Chapter IV) and a meta-analysis of fine root biomass data from 16 Central European beech forests differing in annual precipitation (Leuschner \& Hertel 2003). Thus, experiments with potted young plants and comparative field studies in mature forests produced corresponding evidence that summer drought is an important environmental factor that reduces the standing stock of fine root biomass and the capacity for water and nutrient acquisition of Fagus sylvatica at water-limited sites.

On the other hand, a stimulation of fine root growth in desiccating soil was reported for certain tree species such as white oak (Quercus alba L.) and Douglas-fir (Pseudotsuga menziesii (Mirb.) Franco) (Teskey \& Hinckley 1981, Gower et al. 1992, Joslin \& Wolfe 1998), which would increase the absorbing root surface, thus mitigating the negative physiological consequences of water shortage in periods of drought. Similarly, Leuschner et al. (2001) observed an increase of fine root growth in a Fagus sylvatica stand that was hit by a severe summer drought. Root growth partly compensated for root biomass losses caused by elevated root mortality in the drought period. In our experiment, however, none of the four beech populations responded to the drought treatment with an increase in fine root growth.

It is possible that drought may alter not only total fine root biomass, but also the spatial distribution of tree roots. For example, water-limited trees can redistribute their fine roots to deeper soil horizons with higher soil moisture (Kozlowski et al. 1991, Persson et al. 1995, Hendrick \& Pregitzer 1996). Proliferation of unexplored deeper soil layers and retraction from more drought-exposed upper horizons can be advantageous in 
terms of carbon and nutrient costs of water absorption at dry sites, even though the potential for water extraction in moist periods may be diminished. In our experiment, we did not find a proliferation of fine roots to deeper soil horizons in the dry treatment, although the containers provided sufficient space for deeper root proliferation (Fig. 2). To the contrary: drought-affected beech saplings showed a more surface-oriented distribution of their fine roots than the well watered control. This result highlights the importance of carbohydrate stores in the trunk for any adaptive alteration of root system size and structure upon water and/or nutrient shortage. It appears that active exploration of deeper, increasingly moister soil layers is not an option for beech seedlings or saplings, but only for adult trees, even though soil moisture increased by 0.2 vol. $\%$ per $10 \mathrm{~cm}$ of soil depth in the containers. Therefore, young trees should be more susceptible to drought than older ones with more flexible root growth.

\section{Drought effects on fine root dynamics}

Besides structural adaptation strategies, fine roots may also respond to low soil moisture by altering their dynamic properties. Depending on the drought regime and the plant's growth and carbon allocation strategy, root system responses to drought may vary from a rapid shedding of roots in dry soil to the production of long-lived roots that survive under drought conditions (Santantonio \& Hermann 1985, Pregitzer et al. 1993, Eissenstat 1997). If roots are maintained during short-term unfavourable soil conditions, the construction costs of new root growth, when more favourable soil conditions return, are reduced. Maintenance costs of these long-lived roots can be lowered by decreased root respiration during drought (Bryla et al. 1997, Eissenstat \& Volder 2005). During extended drought periods, however, a more successful strategy can be to decrease the whole plant maintenance costs by shedding roots (Bryla et al. 1997). Since uptake efficiency of roots rapidly declines with age (Bouma et al. 2001, Volder et al. 2004), the hydraulic conductivity of newly produced roots after a drought period may be three times higher than that of older roots (e.g., Huang \& Nobel 1993). Therefore, if roots are produced in the most favourable soil patches and shed when they are no longer efficient in water and nutrient absorption, then total plant production, theoretically, should be maximised (Eissenstat \& Yanai 2002).

In our experiment with beech saplings, the alteration of root longevity seems to play a key role as an adaptive response to soil drought. Median fine root longevity as calculated from the root birth and death events in the mini-rhizotrons varied between 380 and $1060 \mathrm{~d}$ in the four beech populations in the moist control, but decreased to only 200-480 d in the dry treatment (Table 6). Our calculated fine root longevities are 
rather long compared to other studies with woody plants. For example, median fine root longevity varied between 30 and $60 \mathrm{~d}$ in fast-growing fruit trees of the family Rosaceae (Black et al. 1998, Bouma et al. 2001, Pregitzer et al. 1993, Wells \& Eissenstat 2001), between 40 and $900 \mathrm{~d}$ in more slow-growing forest tree species of the Aceraceae (Hendrick \& Pregitzer 1993, Black et al. 1998, Withington et al. 2006), between 80 and $640 \mathrm{~d}$ in some species of the Pinaceae (Majdi \& Kangas 1997, Black et al. 1998, Withington et al. 2006), and from 210 to $350 \mathrm{~d}$ in species of the Fagaceae (Withington et al. 2006). Differences in root longevity may be caused by the different systematic position of the trees, but are more often a consequence of variable environmental conditions. Besides drought, complex interactions with soil biota, shifts in plant defences against root herbivory and parasitism and competition are thought to be important determinants of root lifespan (Wilson et al. 1995, Eissenstat et al. 2000, Wells et al. 2002). In our experiment, species, plant age, soil chemistry, and plant density, which influences root competition, were held constant, while only plant origin and soil moisture were variable. Because we transplanted the beech seedlings in the forest soil, all plants are likely to have been infected with the local mycorrhizal species. Whether or not the mycorrhizal flora was different between the four sites and resulted in different root longevities is not known.

A summer drought of 16 to 18 wks resulted not only in a decrease of median fine root longevity and the associated increase in root turnover, but decreased also the proportion of root length attributable to first- and second-order roots (Table 4). Thus, the beech saplings shed their finest branch roots more rapidly, but partly replaced them by thin, nitrogen-rich, and relatively short-lived finest roots. These rootlets most likely have a particularly high metabolic activity (Pregitzer et al. 1998), thus increasing resource uptake and growth of the saplings, if water and nutrient-rich soil patches are still available. Thus, it appears that alteration of dynamic properties of fine roots is more important than root structural changes in the response of beech saplings to drought.

Root longevity is a parameter that has been found to correlate with a number of other morphological and physiological attributes. For example, short fine root longevity was linked to a small root diameter, low root tissue density, high specific root length, high nitrogen concentration, a high root maintenance respiration rate, high root uptake capacity, and, possibly, a high root hydraulic conductivity in certain species (Fernandez \& Caldwell 1975, Kummerow et al. 1978, Ryser 1996, Eissenstat et al. 2000, Bouma et al. 2001, Wells \& Eissenstat 2003, Tjoelker et al. 2005, Withington et al. 2006). However, contrasting relationships have been found as well. For example, Espeleta \& Donovan (2002) reported among xeric and mesic sand hill tree species the shortest root lifespan and greatest root turnover in the species with thick roots of low SRL and 
high tissue density. Although we identified a tendency for thinner roots in the treatment with short root longevities and high root turnover, a correlation with the logarithm of root longevity was significant neither for root diameter, root tissue density, specific root area, nor for specific root length. Moreover, median root lifespan was independent of leaf lifespan in the dry treatment $(r=0.56, p=0.22)$, indicating physiological autonomy of beech fine roots when exposed to drought. In contrast, in the moist control, there was a significant positive correlation between the logarithm of median fine root longevity and the logarithm of leaf longevity $(r=0.98, p=0.01)$.

\section{Influence of genotype on the root system's drought response}

We expected that beech saplings originating from a drier climate should exhibit a better drought adaptation by reducing root biomass to a lesser extent when growing in dry soil. Indeed, the plants from the drier sites (Ziegelroda and Bleicherode) reduced their root biomass upon drought less than those from moister sites (Fig. 1). Moreover, the dry Ziegelroda site was the only beech population that increased its relative carbon allocation to the root system significantly upon drought.

Discrimination against ${ }^{13} \mathrm{C}$ during photosynthesis is a well characterised phenomenon (Farquhar et al. 1989). However, post-photosynthetic fractionation of stable carbon isotopes further modifies isotopic signatures of individual plant organs. In general, roots are isotopically heavier than leaves (Hobbie et al. 2002, Badeck et al. 2005, Peuke et al. 2006). In our experiment, the drought treatment led to less negative $\delta^{13} \mathrm{C}$-signatures of the root tissue than in the moist control treatment. This can be explained by a higher carbohydrate demand of the stressed root system, which turns over fine root mass at a higher rate. A more rapid root turnover increases plant-internal competition for carbohydrates, thereby decreasing ${ }^{13} \mathrm{C}$-discrimination during root growth. The increase in fine root turnover (and thus in $\delta^{13} \mathrm{C}$ ) with drought was greater in the beech populations from dry sites than in those from moist sites. This matches the observation that rapid shedding and re-growth of fine roots may increase the resource economy of root operation in soils with a patchy and pulsed availability of water and nutrients, because root growth in the favourable soil patches increases the water and nutrient return per unit carbon invested. Although the $\delta^{13} \mathrm{C}$-signatures and the carbon partitioning data indicate differences between individuals from dry and moist sites, a two-factorial analysis of variance of the influence of origin (genetic variability), treatment (phenotypic plasticity) and their interaction on different leaf and root parameters revealed no significant influence of the genotype on any root parameter. 
Table 7. Significance of the effect of origin, treatment, and the interaction of origin and treatment on the variance of 13 leaf and root parameters according to two-factorial analyses of variance. The phenotypic plasticity index $\mathrm{PI}$ is also given for these traits $(x=$ significant influence at $p \leq 0.1, x \times=p \leq 0.05, x \times x=$ $\mathrm{p} \leq 0.01)$.

\begin{tabular}{|c|c|c|c|c|}
\hline Parameter & Origin & Treatment & $\begin{array}{l}\text { Origin } \times \\
\text { Treatment }\end{array}$ & $\begin{array}{l}\text { Plasticity } \\
\text { index }\end{array}$ \\
\hline Leaf size & & $x x$ & & 0.34 \\
\hline Specific leaf area (SLA) & & $x$ & & 0.22 \\
\hline Leaf mass & $x \times x$ & $x x$ & & 0.66 \\
\hline Number of leaves & $x x$ & & & 0.48 \\
\hline Total leaf area & $x \times x$ & $x$ & & 0.60 \\
\hline C partitioning to leaves & $x \times x$ & & & 0.46 \\
\hline$\delta^{13} \mathrm{C}$-signature of leaf mass & & $x \times x$ & $x \times x$ & 0.09 \\
\hline Foliar $\mathrm{N}$-content & $x x$ & $x \times x$ & & 0.32 \\
\hline $\mathrm{C} / \mathrm{N}$ ratio in leaf mass & $x x$ & $x \times x$ & & 0.34 \\
\hline Specific root area (SRA) & & $x$ & & 0.46 \\
\hline Fine root tissue density & & & & 0.42 \\
\hline Fine root mass & & $x \times x$ & & 0.62 \\
\hline Total fine root area & & $x \times x$ & & 0.69 \\
\hline C partitioning to fine roots & & & & 0.35 \\
\hline$\delta^{13} \mathrm{C}$-signature of fine root mass & $x$ & $x \times x$ & $x$ & 0.10 \\
\hline $\mathrm{N}$ content of fine root mass & & & & 0.06 \\
\hline $\mathrm{C} / \mathrm{N}$ ratio of fine root mass & & $x x$ & & 0.04 \\
\hline Relative fine root production & & $x x$ & & 0.96 \\
\hline Fine root turnover & & $x x$ & & 0.94 \\
\hline Root/leaf mass ratio & $x x$ & & & 0.46 \\
\hline Fine root/leaf area ratio & & $x x$ & & 0.48 \\
\hline
\end{tabular}

By contrast, most fine root traits (fine root mass, total fine root area, $\delta^{13} \mathrm{C}$-signature of fine root mass, $\mathrm{C} / \mathrm{N}$ ratio in fine root mass, and relative fine root production and turnover) showed a considerable phenotypic plasticity, i.e., were significantly different under moist and dry conditions (Table 7).

Genetic variability and phenotypic plasticity in the root system's response to drought

For species with broad fundamental niches, the variation in physiological, morphological, and anatomical characteristics may be achieved by a combination of genotypic differentiation and phenotypic plasticity (Cordell et al. 1998). Phenotypic plasticity should be high for traits that are adaptations to more variable environments (Bradshaw 1965, Callaway 2003), while genetic differentiation or specialisation is advantageous in fairly constant environments.

In comparison to other investigations of genetic distances between Fagus sylvatica populations, the distances between the four populations of our study are fairly wide (Konnert 1995, Belletti \& Lanteri 1996, Wang 2003). Analyses of variance revealed a 
marked genotypic control of important leaf traits such as foliar $\mathrm{N}$-content, leaf numbers, and total leaf area in the four populations (Table 7), while most root traits were significantly influenced by phenotypic plasticity (treatment) and the genotypic influence was negligible. Our results indicate that aboveground and belowground organs of young beech trees adapt to summer drought by fundamentally different strategies in terms of genetic and environmental control.

We found the highest plasticity index (PI) for fine root production and turnover (0.95), properties that determine the dynamic response of the root system. In the case of leaf properties, a maximum $\mathrm{PI}$ value of 0.66 was revealed (leaf mass). A much higher phenotypic plasticity of root system properties than leaf traits is understandable, when the spatial and temporal heterogeneity of the aboveground and belowground environments of a plant are compared. The aboveground resource light is more predictably distributed in space than are water and nutrients in the soil, which favours a higher genetic control over leaf and canopy properties. In contrast, the soil environment consists of patches of high water and nutrient availability that change unpredictably in space and time demanding a high degree of phenotypic plasticity in resource uptake rates and root proliferation (Poorter \& Lambers 1986, Grime et al. 1991, Sultan 2001, Kembel \& Cahill 2005). Our data suggest that increased drought tolerance in young beech trees, as is inferred from the drier origin, is primarily based on the enhanced phenotypic plasticity in root dynamics. Moreover, the degree of phenotypic plasticity in root responses to drought varies between genotypes in Fagus sylvatica.

Root systems can show considerable plasticity in the timing of growth and placement, rooting density, absorptive capacity, total surface area, specific root area, and architecture (Teskey \& Hinckley 1981, Kuhns et al. 1985, Jackson et al. 1990, Pregitzer et al. 1993, Fitter 1994, Jackson \& Caldwell 1996, Kutschera \& Lichtenegger 2002, Callaway et al. 2003). Plastic responses to variable resource availabilities are hypothesised to provide a competitive advantage and increase plant fitness. Other studies have failed to detect strong environmental control on root growth and have concluded that fine root dynamics are primarily under endogenous (Kossuth \& Ross 1987, Hendrick \& Pregitzer 1997, Côté et al. 1998, Joslin et al. 2001) or genetic (Aspelmeier \& Leuschner 2006) control. In common garden experiments with beech, Italian and Spanish provenances were shown to have a greater relative biomass allocation to roots than mesic populations from Central Europe (Tognetti et al. 1995, García-Plazaola \& Becerril 2000), which points to an at least partial genetic background of root drought response in these drought-exposed beech populations. Further studies on the foraging precision of fine root dynamics of beech are needed to 
provide a more detailed understanding of the benefits gained by increased phenotypic plasticity belowground.

\section{Conclusions}

The root system of Fagus sylvatica saplings responds to summer drought primarily by shortening root lifespan and thus enhancing fine root turnover. The two consecutive summer drought periods accelerated the shedding of finest roots, while the birth of new rootlets decreased greatly. Consequently, we observed a marked decrease in root mass upon drought, but no principal alteration of root system structure or rooting depth. Thus, the root system of the young trees responded mainly in terms of altered root dynamics, which emphasises the importance of phenotypic plasticity, while genetically determined carbon partitioning patterns remained rather stable. Compared to other Central European tree species, Fagus sylvatica has only limited between-population genetic variability, which nevertheless has a large influence on the variability of leaf traits. Thus it appears that aboveground traits of young beech trees are primarily controlled by genotypic variation, while fine root growth and turnover are subject to high phenotypic plasticity; the latter, however, varies to a certain extent with genotype.

\section{Acknowledgements}

The authors would like to thank Heiko Eichner for his invaluable help in constructing the experimental set-up in the containers of the Rhizolab and Mechthild Stange and Uta Nüsse-Hahne for their help in the labour-intensive work of collecting mini-rhizotron images. We also would like to thank Melanie Jones and one anonymous referee for their helpful reviews of this manuscript. We gratefully acknowledge the financial support granted to I.C. Meier by the Deutsche Bundesstiftung Umwelt. 
Chapter 6

Synopsis 


\section{Competing effects of phenology and precipitation, temperature and nutrient availability on leaves of European beech}

Plants tend to produce smaller, more xeromorphic leaves and a reduced total leaf area when exposed to drought (e.g., Hinckley et al. 1981, Kozlowski \& Pallardy 1997). The large majority of studies in mature forests therefore reported a positive relationship between precipitation or soil water availability and leaf area index (e.g., Grier and Running 1977, Hinckley et al. 1981, Runyon et al. 1994, Turner 1994, Jose \& Gillespie 1997). On the contrary, in the present study, both average leaf size and leaf area index (LAI) of mature beech stands increased with a decrease in precipitation, independently of the method applied for leaf area determination (litter sampling or mid-summer harvesting of sun-crown leaves). In stands with less than $550 \mathrm{~mm} \mathrm{yr}^{-1}$ the average leaf was about $40 \%$ larger and had a higher specific leaf area (SLA) than the average leaf in stands with more than $900 \mathrm{~mm} \mathrm{yr}^{-1}$. While the total number of leaves per ground area tended to decrease with declining rainfall, this reduction did not compensate for the increase in average leaf size. As a result, LAI significantly increased from the high- to the low-precipitation stands by $1-2 \mathrm{~m}^{2} \mathrm{~m}^{-2}$.

The explanation for the unexpected drought responses of the leaves of European beech can partly be found in phenology. Leaf production of beech is temporarily uncoupled from summer droughts, as they develop later in the year, because leaf expansion predominantly takes place in May, when the water content of forest soils has reached field capacity. Ample soil water reserves indicated that drought stress cannot be an important factor in this critical period of leaf development, neither in the moist nor in the dry sections of the transect. Leaf size development and summer droughts, as they develop later in the year, seem to be seasonally disconnected in temperate forests such as beech forests (cf. Hanson \& Weltzin 2000, Wullschleger \& Hanson 2006). The onset of leaf growth in spring coincided with rising temperatures, which was the major factor determining average leaf size, whereas the influence of soil moisture and nitrogen supply was low.

Nevertheless, water shortage during mid-summer affected leaves of the low precipitation stands stronger than those in the moister section of the transect, as was evidenced by a greater reduction of leaf stomatal conductance and, thus, photosynthetic $\mathrm{C}$-fixation. Maintenance of a high LAI, even in the driest environments that are tolerated by this species, reflects the conflicting demands of competitive and stress tolerating strategies on plant physiology and morphology: producing a high LAI supports the survival strategies of late-successional European beech to outmatch competitors by casting deep shade. A determinate mode of leaf expansion in the early summer and physiological failure later in the year must be seen as unavoidable tradeoff to reach competitive superiority in a large range of environments. 


\section{Optimal carbon partitioning to beech fine roots?}

Predictions of the response of trees and forests to a possibly drier climate must consider long-term adaptive responses and highly flexible resource partitioning patterns in these long-lived plants and ecosystems. According to the optimal resource partitioning theory, plants should allocate the relatively more carbon and nutrients to root growth than to aboveground growth, when plant growth is limited by water and/or nutrient shortage (Bloom et al. 1985). On the other hand, the more factors like radiation or $\mathrm{CO}_{2}$ are limiting, the relatively more carbon should be allocated to leaves. Plants in desiccated soil are therefore expected to enhance fine root growth $(<2 \mathrm{~mm}$ in diameter), thus maximizing efficiency for water capture during drought.

This hypothesis could not be supported for European beech. This study revealed a substantial decrease of the fine root biomass and total root area of European beech with a decrease in soil moisture: mature stands and beech saplings under water limitation had only $60-65 \%$ of the fine root biomass at ample water supply. The ratio of fine root area to leaf area was significantly shifted to the disadvantage of the root surface in stands with low annual rainfall (Fig. 1a) or in saplings of dry origins (Fig. 1b), while the relative carbon partitioning to leaves increased.
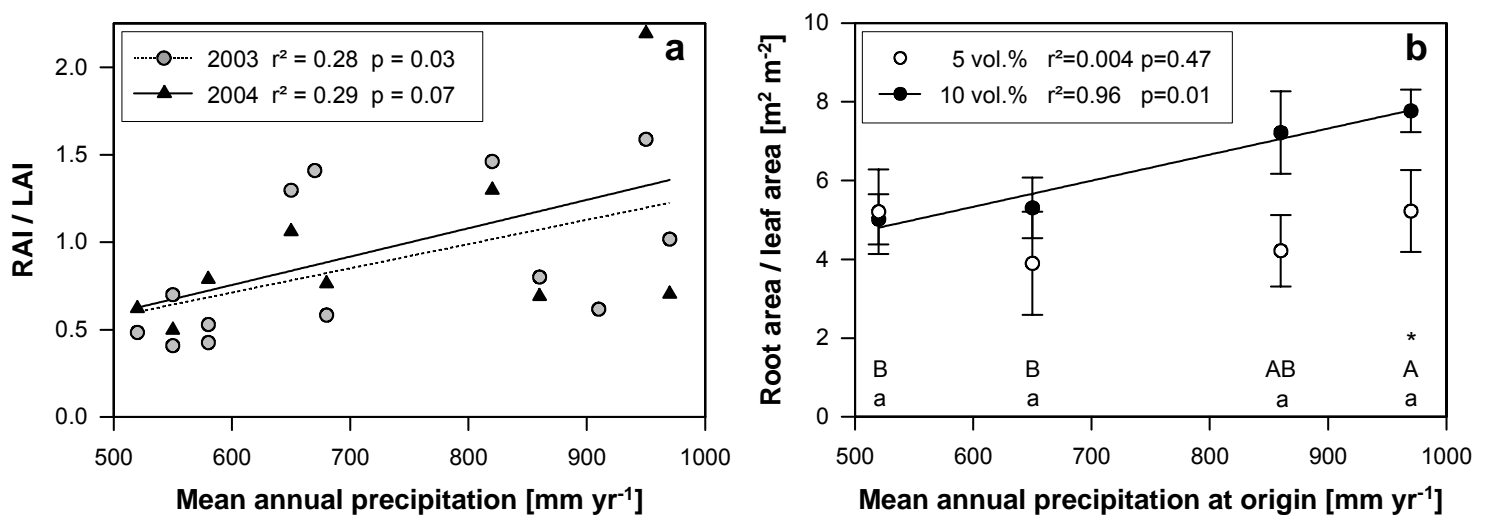

Figure 1a. Relationship between mean annual precipitation and the root area index (RAI)/leaf area index (LAl) ratio in 13 (2004: nine) mature beech forests along a precipitation gradient in central Germany. Figure 1b. Relationship between mean annual precipitation at plant origin and the fine root/leaf area ratio of four different beech populations grown at two soil moisture levels in the Göttingen Rhizolab (mean and standard error of four beech saplings per origin and treatment). Significant differences between origins are indicated for high soil moisture by different capital letters and for low soil moisture by different lower case letters; differences significant at $p \leq 0.1$ between the treatments are marked with *.

In mature beech stands, fine root productivity was not enhanced, but remained stable across the rainfall transect, independent of any of the investigated environmental parameters. Summer droughts later in the year led to increased root mortality, thus to higher fine root carbon turnover and reduced fine root biomass in the drier stands. 
Obviously, drought did not increase fine root production in absolute, but in relative terms (fine root productivity per standing root biomass) in the drier stands. In beech saplings, summer drought even led to a 10 -fold reduction in fine root growth rate. Due to a simultaneous reduction of median fine root lifespan by roughly $50 \%$, fine root carbon turnover of tree saplings increased, as it did in mature stands.

Beech trees seem to be able to meet their water demands in drier environments with a remarkably small fine root biomass and total fine root surface area. While the optimal partitioning theory fails to explain the observed decrease in the fine root/leaf biomass ratio with decreasing soil moisture, the theory is supported by the data if modified to account for carbon allocation to roots is considered, which would account for enhanced root turnover in drier environments.

\section{Adaptive fine root responses of beech to drought}

Several adaptive drought responses of tree fine root systems are known. For example, water limited trees can redistribute their fine roots to deeper soil horizons with higher soil moisture (Kozlowski et al. 1991, Persson et al. 1995, Hendrick \& Pregitzer 1996). Proliferation into unexplored deeper soil can be advantageous in terms of carbon and nutrient costs of water absorption at dry sites. In mature beech stands, we found a retreat of fine root biomass from drought-exposed organic layers to the upper mineral soil with decreasing precipitation, though not a marked re-distribution to deeper soil horizons. In beech saplings an active proliferation of fine roots to deeper soil horizons as a response to water shortage could not be found. By contrast, the drought-affected beech saplings showed a more surface-oriented distribution of their fine roots than the well watered control. This result highlights the importance of carbohydrate stores in the trunk for any adaptive alteration of root system size and structure upon water and/or nutrient shortage.

The carbon and nutrient costs of water uptake should be lower in small-diameter roots (Tyree et al. 1998), favouring thin roots in terms of resource economy under waterlimited conditions over thicker ones (Eissenstat \& Yanai 1997). Indeed, average diameter of fine roots of adult trees decreased with declining annual precipitation, suggesting an improvement of the cost/benefit ratio of root operation towards drier climates. Additionally, the higher fine root surface area partly compensated for the smaller total fine root biomass in the drier stands. Beech saplings also reduced average root diameter. However, specific root area decreased with drought, because root tissue density tended to be higher. This may reflect the compromise roots have to find between drought resistance, which is linked to robustness and a high tissue 
density (Wahl \& Ryser 2000, Craine et al. 2001, Lux et al. 2002), and low resource investment by thinner roots in a drought-affected soil, where the risk of root loss is high. Besides structural adaptation strategies, fine roots may also adapt to low soil moisture by adjusting their dynamic properties. These root system responses may vary from a rapid shedding of roots in dry soil to the production of long-lived roots that survive under drought (Santantonio \& Hermann 1985, Pregitzer et al. 1993, Eissenstat 1997). In this study, the root system of beech saplings responded to summer drought primarily by shortening root lifespan, thus enhancing fine root turnover in soil patches where moisture was already depleted. Readily shedding of fine roots reduces the whole plant maintenance costs, thus it can maximise the overall tree productivity in desiccated soil.

\section{Phenotypic plasticity and genetic variability determine the drought response of European beech}

Variation within populations may increase adaptability to a changing environment, and can be achieved by different means: a species can exhibit a high degree of genetic variability, comprising genotypes specifically adapted to different environments, or a given genotype can exhibit a certain degree of phenotypic plasticity, coding for the ability of the individual to express different physiological or morphological phenotypes in different environments (Gregorius \& Kleinschmit 1999, Pigliucci 2001, Callaway et al. 2003). For species with broad fundamental niches such as European beech, the variation in physiological, morphological, and anatomical characteristics may be achieved by a combination of genotypic differentiation and phenotypic plasticity (Cordell et al. 1998). Phenotypic plasticity should be high for traits that are adaptations to more variable environments (Bradshaw 1965, Callaway 2003), while genetic differentiation or specialisation is advantageous in fairly constant environments.

In European beech, a genotypic control of important leaf traits such as foliar N-content, leaf numbers, and total leaf area were revealed, while most root traits were significantly influenced by phenotypic plasticity, and the genotypic influence was negligible. Our results indicate that aboveground and belowground organs of young beech trees adapt to summer drought by fundamentally different strategies in terms of genetic and environmental control. When comparing the spatial and temporal heterogeneity of the environments, the aboveground resource light is more predictably distributed in space than water and nutrients in the soil, which favours a higher genetic control over leaf and canopy properties. By contrast, the soil environment consists of patches of high water and nutrient availability that change unpredictably in space and time demanding a high 
degree of phenotypic plasticity in resource uptake rates and root proliferation (Poorter \& Lambers 1986, Grime et al. 1991, Sultan 2001). An increased drought tolerance in young beech trees is presumably primarily based on the enhanced phenotypic plasticity of the fine root system: expansive fine root growth in favourable soil conditions, reduced fine root longevity and increased turnover with drought, and the ability to provide for the water demands even with a strongly reduced fine root mass. 


\section{Conclusions}

This study demonstrates that

(i) leaf expansion and stand leaf area index of European beech are temporarily uncoupled from summer droughts, and are mainly controlled by rising soil temperatures in moist spring,

(ii) beech maintains a high leaf area even in the driest environments that are tolerated by this species, because a high LAl supports the survival strategy of this late successional tree species to outmatch competitors by casting deep shade,

(iii) the optimal partitioning theory fails to explain the observed decrease in beech fine root/leaf biomass ratio with decreasing precipitation, but is supported if modified to account for carbon allocation to roots, which would account for enhanced root turnover in drier environments,

(iv) adaptive drought responses of beech fine roots are (a) a decrease in mean fine root diameter, (b) a decrease in root lifespan and (c) an apparent change in root carbon turnover patterns,

(v) a considerable plasticity of the fine root system is most likely one of the reasons for European beech being successful in high- and low-precipitation environments, and

(vi) an increased drought tolerance in beech trees is primarily based on the enhanced phenotypic plasticity in fine root growth and turnover, i.e., in root dynamics.

When predicting the effects of increasing summer droughts on temperate broad-leaved tree species, belowground plasticity of the fine root system must be taken into account. Studies including direct observation of root turnover of adult trees with the minirhizotron technique and throughfall exclusion experiments in mature stands across precipitation transects are needed to provide a more detailed understanding of the relationship between beech fine root dynamics and water availability under field conditions. In particular secondary important stresses like rhizovory (root consumption) that could substantially increase with global warming, and altered competition pressure have to be incorporated. 


\section{Summary}

Global warming due to an increase in anthropogenic greenhouse gas concentrations is undisputed now and will have consequences for the global hydrological cycle. For Germany, a shift of the seasonal distribution of precipitation to reduced rainfall in summer and enhanced precipitation in winter is expected, especially in the eastern, by now more continental part of Germany. The estimated rates of future climatic change are expected to outpace migration or succession rates of many plants. Therefore, plants will have to respond to these rapidly changing climatic conditions or they will face local extinction if they are not sufficiently adapted to altered drought and temperature conditions.

In Germany, the economically most important broad-leaved tree species is European beech (Fagus sylvatica L.). Although beech is a late-successional tree species with a high dominance on a broad range of soil chemical and hydrological site conditions, F. sylvatica is more drought-sensitive than other temperate broad-leaved trees. Hence, increasing summer droughts could in future impair the vitality of beech at the drought limit of its occurrence.

In this study, the drought response of beech was studied simultaneously at several levels. The focus was on the two key interfaces for water flow in the soil-plantatmosphere continuum (SPAC): fine roots and leaves. Studies were conducted with both beech saplings and mature forest stands. A major aim was the investigation of long-term adaptive responses of adult beech trees to low soil moisture. In the centre of Germany, the response of the leaf and the fine root system of 14 mature forest stands to a large decrease in annual rainfall from $970 \mathrm{~mm} \mathrm{yr}^{-1}$ to $520 \mathrm{~mm} \mathrm{yr}^{-1}$ were studied. In this region, topographic conditions cause a change of precipitation conditions at a relatively small scale, while a bed of uniform geological substrate ensures sufficient comparability of soil chemical conditions. A second aim was the experimental investigation of the specific contribution of phenotypic plasticity and genetic variability to the drought response of beech in a common garden experiment. This experiment was conducted in the Göttingen Rhizolab Facility, an outdoor laboratory for the experimental investigation of the growth dynamics of root systems of woody plants. Beech trees from four different provenances contrasting in precipitation at origin were grown in large containers with precise control of soil moisture.

Surprisingly, adult trees responded to a large decrease in annual rainfall along the transect with an increase of leaf area and leaf area index ( $\mathrm{LAl}$ ), even though the total number of leaves per ground area decreased. This result contrasts with the widespread 
believe that plants reduce their leaf area and form more xeromorphic leaves upon drought. It appears that beech leaf expansion was more strongly influenced by air temperature, whereas influences of soil moisture and nitrogen were surprisingly low.

The optimal resource partitioning theory predicts enhanced root growth during drought in order to reduce water limitation in a desiccated soil. This hypothesis could not be supported for European beech. Under water limitation, beech rather decreased fine root biomass by about a third due to reduced fine root longevity and increased root turnover. Beech trees seem to be able to meet their water demand in drier environments with a remarkably small fine root biomass and total surface area.

The explanation for the unexpected drought responses of European beech can partly be found in phenology: leaf production is temporarily uncoupled from summer droughts, because leaf expansion takes place in May, when ample soil water reserves exist in both high- and low-precipitation stands. Not water is the limiting factor, but temperature and to a minor extent soil nitrogen supply. On the other hand, fine root production can almost constantly proceed during the whole growing season. With drought, fine root longevity in unfavourable soil patches decreases and roots are readily shed to reduce maintenance costs, thus maximizing overall tree productivity. However, leaf response is not as plastic in dry summer conditions as root dynamics. Hence, the poor match between leaf area and summer drought cause several physiological limitations. Producing a high LAI despite the desiccated soil in summer supports the survival strategies of late-successional European beech to outmatch competitors by casting deep shade.

Aboveground and belowground organs of beech adapt to summer drought by fundamentally different strategies in terms of genetic and environmental control: the limited between-population genetic variability determines important leaf traits of European beech. Yet, an increased drought tolerance is in this species presumably primarily based on the enhanced phenotypic plasticity of the fine root system: expansive fine root growth in favourable soil conditions, reduced fine root longevity and increased turnover with drought, and the ability to provide for the water demands even with a strongly reduced fine root mass. 


\section{Zusammenfassung}

Die prognostizierte globale Klimaerwärmung aufgrund eines Anstieges an Treibhausgasen wird Konsequenzen für den Wasserkreislauf der Biosphäre haben. Für Deutschland wird eine Verschiebung der saisonalen Niederschlagsverteilung prognostiziert, die zu reduzierten Regenmengen im Sommer und Anstiegen im Winter führen wird. Dies wird insbesondere in den östlichen Gebieten von Deutschland der Fall sein, die ein kontinentaleres Klima besitzen. Die berechnete Geschwindigkeit dieser Klimaänderungen wird aber die Migrations- oder Sukzessionsraten von Pflanzen vermutlich bei weitem übersteigen, so dass sie vom lokalen Aussterben bedroht sind, wenn ihre Anpassungsfähigkeit an die veränderten Trockenheits- und Temperaturbedingungen nicht ausreichend ist.

In Mitteleuropa ist die ökonomisch wichtigste Laubbaumart die Rotbuche (Fagus sylvatica L.). Obwohl die Buche eine spät-sukzessionale Baumart ist, die hinsichtlich der bodenchemischen und -hydrologischen Bedingungen als anpassungsfähig gilt, wird F. sylvatica als trockenheitsempfindlicher als andere Laubbäume aus der gemäßigten Zone eingestuft. Zunehmende Trockenheit im Sommer könnte daher die Vitalität von F. sylvatica einschränken.

In der vorliegenden Studie wurde der Einfluss von Trockenheit auf die Rotbuche untersucht. Im Mittelpunkt standen dabei diejenigen Pflanzenoberflächen, die die Wasseraufnahme und -abgabe des Baumes regeln: Die Feinwurzeln und die Blätter. Ein Ziel dieser Studie war die Untersuchung von langfristigen Anpassungsreaktionen an geringe Bodenfeuchte bei F. sylvatica. Entlang eines steilen Niederschlagsgradienten von 970 auf $520 \mathrm{~mm}$ in der Mitte Deutschlands wurde die Reaktion des Blatt- und Feinwurzelsystems von Buchenaltbeständen auf ein reduziertes Wasserangebot untersucht. In dieser Region verursachen die topographischen Bedingungen einen relativ kleinräumigen Wechsel der Niederschläge, während das geologische Ausgangsgestein Mittlerer Buntsandstein durchgehend vorhanden ist und ausreichende Vergleichbarkeit der bodenchemischen Bedingungen garantiert. Das Ziel eines common garden-Experimentes war es, zwischen phänotypischer Plastizität und genotypischer Variabilität bei der Trockenheitsantwort von $F$. sylvatica zu differenzieren. Das Experiment wurde in der Anlage des Göttinger Rhizolabs durchgeführt, einem einzigartigen Freilandlabor zur experimentellen Untersuchung der Wurzeldynamik von Waldbäumen. Vier unterschiedliche Buchenprovenienzen, die sich in der Niederschlagsmenge im Herkunftsgebiet unterschieden, wurden unter 
definierten Bodenfeuchte- und natürlichen Witterungsbedingungen bei gleichzeitig unbegrenztem Wurzelraum herangezogen.

Überraschenderweise reagierten die Blätter der Buchenaltbäume entlang des Transektes auf eine starke Abnahme des jährlichen Niederschlages mit einer Zunahme der Blattfläche und, trotz einer Reduktion der Gesamtblattzahl, sogar mit einer Zunahme des Blattflächenindexes (LAI). Dieses Ergebnis steht im Widerspruch zu der allgemeinen Annahme der Ausbildung von kleineren, xeromorpheren Blättern bei Trockenheit. Die Buchenblätter und ihr Streckungswachstum wurden offensichtlich stärker von der Lufttemperatur beeinflusst als von der Bodenfeuchte oder der Stickstoffversorgung.

Die Optimalitätstheorie der pflanzlichen Ressourcennutzung sagt für Bedingungen von Wassermangel ein verstärktes Wurzelwachstum voraus; dies konnte für die Rotbuche weder im Freiland noch im Jungpflanzen-Experiment bestätigt werden. Im Gegenteil, die Buche reduzierte bei Trockenstress aufgrund einer verkürzten Wurzellebensdauer und einer reduzierten Neubildungsrate der Wurzeln die Feinwurzelbiomasse sogar um ein Drittel. F. sylvatica scheint also in der Lage zu sein, ihren Wasserbedarf bei trockeneren Umweltbedingungen mit einer auffällig geringen Feinwurzelbiomasse und Wurzeloberfläche zu decken.

Eine Erklärung für die überraschenden Trockenheitsantworten der Rotbuche liegt teilweise in der Phänologie dieser Art: Die Blattproduktion ist zeitlich abgekoppelt von der Sommertrockenheit; die Blattentfaltung findet im feuchten Frühling statt, wenn noch ausreichende Wasserreserven in den niederschlagsreichen, aber auch in den niederschlagsarmen Beständen vorliegen. Nicht das Wasser ist dann der limitierende Faktor, sondern die Temperatur und in geringerem Maße auch die Stickstoffnachlieferung. Im Unterschied dazu können Feinwurzeln fast während der gesamten Vegetationsperiode produziert werden. Bei Trockenheit nimmt die Lebensdauer der Feinwurzeln in ungünstigen Bereichen des Bodenprofils allerdings ab und die feinsten Wurzeln werden schnell abgeworfen, um ihre Erhaltungskosten zu reduzieren und so die Gesamtproduktivität des Baumes zu maximieren. Die Reaktion von Blättern ist jedoch weniger plastisch gegenüber Sommertrockenheit als die Wurzeldynamik. Das Verhalten von F. sylvatica, trotz längerer Trockenperioden im Sommer einen hohen LAl aufrecht zu erhalten, unterstützt die Strategie dieses spätsukzessionalen Baumes, Konkurrenten durch einen hohen Schattenwurf auszuschalten.

Obwohl Blätter und Feinwurzeln Organe desselben Organismus sind, passen sich die ober- und unterirdischen Organe der Buche mit grundlegend unterschiedlichen Strategien an Sommertrockenheit an: Die ohnehin recht geringe genetische Variabilität 
zwischen verschiedenen Rotbuchenpopulationen beeinflusst wichtige Blattmerkmale. Für die Trockenheitstoleranz der Buche ist jedoch wahrscheinlich die hohe phänotypische Plastizität des Feinwurzelsystems von erheblicher Bedeutung: Expansives Wurzelwachstum bei günstigen Bodenverhältnissen, reduzierte Feinwurzellebensdauer und erhöhter Umsatz bei Trockenheit und die Fähigkeit, die Wasserversorgung auch mit einer stark reduzierten Feinwurzelmasse zu gewährleisten. 


\section{References}

Aber JD, Nadelhoffer KJ, Steudler P, Melillo JM (1989) Nitrogen saturation in northern forest ecosystems. Bioscience 39 378-386.

Aerts R (1997) Climate, leaf litter chemistry and leaf litter decomposition in terrestrial ecosystems: a triangular relationship. Oikos 79 439-449.

Agrawal AA (2001) Ecology - phenotypic plasticity in the interactions and evolution of species. Science 294 321-326.

Albers D, Migge S, Schäfer M, Scheu S (2004) Decomposition of beech leaves (Fagus sylvatica) and spruce needles (Picea abies) in pure and mixed stands of beech and spruce. Soil Biol Biochem 36 155-164.

Alexander IJ, Fairley RI (1983) Effects of N fertilization on populations of fine roots and mycorrhizas in spruce humus. Plant Soil 71 49-53.

Arbeitskreis Standortskartierung in der Arbeitsgemeinschaft Forsteinrichtung (1996) Forstliche Standortsaufnahme. IHW, Eching, 352 p.

Ares A, Fownes JH (1999) Water supply regulates structure, productivity, and water use efficiency of Acacia koa forests in Hawaii. Oecologia 121 458-466.

Aspelmeier S, Leuschner Ch (2006) Genotypic variation in drought response of silver birch (Betula pendula Roth): leaf and root morphology and carbon partitioning. Trees-Struct Funct 20 42-52.

Austin AT, Vitousek PM (1998) Nutrient dynamics on a precipitation gradient in Hawai'i. Oecologia 113 519-529.

Backes K, Leuschner Ch (2000) Leaf water relations of competitive Fagus sylvatica and Quercus petraea trees during 4 years differing in soil drought. Can $\mathrm{J}$ Forest Res 30 335-346.

Badeck FW, Tcherkez G, Nogues S, Piel C, Ghashghaie J (2005) Post-photosynthetic fractionation of stable carbon isotopes between plant organs - a widespread phenomenon. Rapid Commun Mass Sp 19 1381-1391.

Barceló J, Poschenrieder C (2002) Fast root growth responses, root exudates, and internal detoxification as clues to the mechanisms of aluminium toxicity and resistance: a review. Environ Exp Bot 48 75-92.

Battaglia M, Cherry ML, Beadle CL, Sands PJ, Hingston A (1998) Prediction of leaf area index in eucalyptus plantations: effects of water stress and temperature. Tree Physiol 18 521-528.

Bauhus J, Bartsch N (1996) Fine-root growth in beech (Fagus sylvatica) forest gaps. Can J Forest Res 26 2153-2159.

Bazzaz FA (1990) The response of natural ecosystems to the rising global $\mathrm{CO}_{2}$ levels. Annu Rev Ecol Syst 21 167-196.

Becker M (1989) The role of climate on present and past vitality of silver fir forests in the Vosges-Mountains of north-eastern France. Can J Forest Res 19 1110-1117.

Becker M, Nieminen TM, Gérémia F (1994) Short-term variations and long-term changes in oak productivity in north-eastern France. The role of climate and atmospheric $\mathrm{CO}_{2}$. Ann Sci Forest 51 477-492.

Begg JE (1980) Morphological adaptations of leaves to water stress. In: Adaptation of plants to water and high temperature stress (eds Turner NC, Kramer PJ), pp. 33-42. Wiley, New York. 
Belletti P, Lanteri S (1996) Allozyme variation among European beech (Fagus sylvatica L.) stands in Piedmont, north-western Italy. Silvae Genet 45 33-37.

Berg B, Johansson MB, Meentemeyer V (2000) Litter decomposition in a transect of Norway spruce forests: substrate quality and climate control. Can J Forest Res $\mathbf{3 0}$ 1136-1147.

Bergh J, Freeman M, Sigurdsson B, Kellomaki S, Laitinen K, Niinisto S, Peltola H, Linder S (2003) Modelling the short-term effects of climate change on the productivity of selected tree species in Nordic countries. Forest Ecol Manag 183 327-340.

Bergkvist B, Folkeson L (1992) Soil acidification and element fluxes of a Fagus sylvatica forest as influenced by simulated nitrogen deposition. Water Air Soil Poll 65 111-133.

Betts RA, Cox PM, Lee SE, Woodward FI (1997) Contrasting physiological and structural vegetation feedbacks in climate change simulations. Nature 387 796799.

Bishop K, Dambrine E (1995) Localization of tree water-uptake in Scots pine and Norway spruce with hydrological tracers. Can J Forest Res 25 286-297.

Black KE, Harbron CG, Franklin M, Atkinson D, Hooker JE (1998) Differences in root longevity of some tree species. Tree Physiol 18 259-264.

Bloom AJ, Chapin III FS, Mooney HA (1985) Resource limitation in plants - an economic analogy. Annu Rev Ecol Syst 16 363-392.

Bohn U (1992) Zum internationalen Projekt einer Karte der natürlichen Vegetation Europas im Maßstab 1:2,5 Mio. Konzept, Inhalt Erarbeitung, kartographische Darstellung und Anwendungsmöglichkeiten. Natur und Landschaft 67 476-480.

Bongarten BC, Teskey RO (1987) Dry weight partitioning and its relationship to productivity in Loblolly pine seedlings from seven sources. Forest Sci 33 255-267.

Borken W, Savage K, Davidson EA, Trumbore SE (2006) Effects of experimental drought on soil respiration and radiocarbon efflux from a temperate forest soil. Glob Change Biol 12 177-193.

Bouma TJ, Yanai RD, Elkin AD, Hartmond U, Flores-Alva DE, Eissenstat DM (2001) Estimating age-dependent costs and benefits of roots with contrasting life span: comparing apples and oranges. New Phytol 150 685-695.

Bowman RA, Cole CV (1978) An exploratory method for fractionation of organic phosphorus from grassland soils. Soil Sci 25 95-101.

Bradshaw AD (1965) Evolutionary significance of phenotypic plasticity in plants. Adv Genet 13 115-155.

Braun S, Flückiger W (1987) Untersuchungen an Gipfeltrieben von Buche (Fagus sylvatica L.). Bot Helv 97 61-73.

Bray EA (2004) Genes commonly regulated by water-deficit stress in Arabidopsis thaliana. J Exp Bot 55 2331-2341.

Bréda N, Cochard H, Dreyer E, Granier A (1993) Field comparison of transpiration, stomatal conductance and vulnerability to cavitation of Quercus petraea and Quercus robur under water stress. Ann Sci Forest 50 571-582.

Bréda N, Granier A (1996) Intra- and interannual variations of transpiration, leaf area index and radial growth of a sessile oak stand (Quercus petraea). Ann Sci Forest 53 521-536. 
Bréda N, Huc R, Granier A, Dreyer E (2006) Temperate forest trees and stands under severe drought: a review of ecophysiological responses, adaptation processes and long-term consequences. Ann For Sci 63 625-644.

Brockmann WG, Eckstein D, Aniol RW (1987) Dendroklimatologische Untersuchungen zur Bedeutung des Produktionsfaktor Wasser für das Baumwachstum. Forstwiss Centralbl 106 340-354.

Bryla DR, Bouma TJ, Eissenstat DM (1997) Root respiration in citrus acclimates to temperature and slows during drought. Plant Cell Environ 20 1411-1420.

Bundesministerium für Ernährung Landwirtschaft und Forsten (1994) Bundesweite Bodenzustandserhebung im Wald (BZE): Arbeitsanleitung. BMELF, Bonn, 158 p.

Burk D (2006) Physiologische, anatomische und chemische Aspekte der Regulation der Wurzelwasseraufnahme bei Rotbuche, Kiefer und Birke auf zwei unterschiedlich wasserversorgten Standorten. $\mathrm{PhD}$ thesis, University of Göttingen. http://webdoc.sub.gwdg.de/diss/2006/burk/burk.pdf.

Burton AJ, Pregitzer KS, Hendrick RL (2000) Relationships between fine root dynamics and nitrogen availability in Michigan northern hardwood forests. Oecologia 125 389-399.

Bussotti F, Borghini F, Celesti C, Leonzio C, Bruschi P (2000) Leaf morphology and macronutrients in broadleaved trees in central Italy. Trees-Struct Funct 14 361368.

Callaway RM, Pennings SC, Richards CL (2003) Phenotypic plasticity and interactions among plants. Ecology 84 1115-1128.

Carbon BA, Bartle GA, Murray AM, Macpherson DK (1980) The distribution of root length, and the limits to flow of soil-water to roots in a dry sclerophyll forest. Forest Sci 26 656-664.

Cech PG, Pepin S, Körner C (2003) Elevated $\mathrm{CO}_{2}$ reduces sap flux in mature deciduous forest trees. Oecologia 137 258-268.

Chalecki EL, Gleick PH (1999) A framework of ordered climate effects on water resources: a comprehensive bibliography. J Am Water Resour As 35 1657-1665.

Cheliak WM, Pitel JA (1984) Techniques for starch gel electrophoresis of enzymes from forest tree species. Petawa National Forestry Institute, Ontario, $49 \mathrm{p}$.

Ciais P, Reichstein M, Viovy N, Granier A, Ogee J, Allard V, Aubinet M, Buchmann N, Bernhofer C, Carrara A, Chevallier $F$, De Noblet N, Friend AD, Friedlingstein $P$, Grunwald T, Heinesch B, Keronen P, Knohl A, Krinner G, Loustau D, Manca G, Matteucci G, Miglietta F, Ourcival JM, Papale D, Pilegaard K, Rambal S, Seufert G, Soussana JF, Sanz MJ, Schulze ED, Vesala T, Valentini R (2005) Europe-wide reduction in primary productivity caused by the heat and drought in 2003 . Nature 437 529-533.

Cochard H, Lemoine D, Ameglio T, Granier A (2001) Mechanisms of xylem recovery from winter embolism in Fagus sylvatica. Tree Physiol 21 27-33.

Comas LH, Eissenstat DM, Lakso AN (2000) Assessing root death and root system dynamics in a study of grape canopy pruning. New Phytol 147 171-178.

Comps B, Thiebaut B, Paule L, Merzeau D, Letouzey J (1990) Allozymic variability in beechwoods (Fagus sylvatica L.) over Central Europe - spatial differentiation among and within populations. Heredity 65 407-417.

Comps B, Gömöry D, Letouzey J, Thiébaut B, Petit RJ (2001) Diverging trends between heterozygosity and allelic richness during postglacial colonization in the European beech. Genetics 157 389-397. 
Cordell S, Goldstein G, Mueller-Dombois D, Webb D, Vitousek PM (1998) Physiological and morphological variation in Metrosideros polymorpha, a dominant Hawaiian tree species, along an altitudinal gradient: the role of phenotypic plasticity. Oecologia 113 188-196.

Côté B, Hendershot WH, Fyles JW, Roy AG, Bradley R, Biron PM, Courchesne F (1998) The phenology of fine root growth in a maple-dominated ecosystem: relationships with some soil properties. Plant Soil 201 59-69.

Craine JM, Froehle J, Tilman DG, Wedin DA, Chapin FS (2001) The relationships among root and leaf traits of 76 grassland species and relative abundance along fertility and disturbance gradients. Oikos 93 274-285.

Cuguen J, Merzeau D, Thiebaut B (1988) Genetic structure of the European beech stands (Fagus sylvatica L.): F-statistics and importance of mating system characteristics in their evolution. Heredity 60 91-100.

Cunningham SA, Summerhayes B, Westoby M (1999) Evolutionary divergences in leaf structure and chemistry, comparing rainfall and soil nutrient gradients. Ecol Monogr 69 569-588.

Dale VH, Joyce LA, McNulty S, Neilson RP, Ayres MP, Flannigan MD, Hanson PJ, Irland LC, Lugo AE, Peterson CJ, Simberloff D, Swanson FJ, Stocks BJ, Wotton BM (2001) Climate change and forest disturbances. Bioscience 51 723-734.

Damesin C, Lelarge C (2003) Carbon isotope composition of current-year shoots from Fagus sylvatica in relation to growth, respiration and use of reserves. Plant Cell Environ 26 207-219.

Davidson EA, Ishida FY, Nepstad DC (2004) Effects of an experimental drought on soil emissions of carbon dioxide, methane, nitrous oxide, and nitric oxide in a moist tropical forest. Glob Change Biol 10 718-730.

Davis JP, Haines B, Coleman D, Hendrick R (2004) Fine root dynamics along an elevational gradient in the southern Appalachian Mountains, USA. Forest Ecol Manag 187 19-34.

Deans JD (1979) Fluctuations of the soil environment and fine root growth in a young Sitka spruce plantation. Aust J Bot 31 615-627.

Demesure B, Comps B, Petit RJ (1996) Chloroplast DNA phylogeography of the common beech (Fagus sylvatica L.) in Europe. Evolution 50 2515-2520.

Desprez-Loustau ML, Marcais B, Nageleisen LM, Piou D, Vannini A (2006) Interactive effects of drought and pathogens in forest trees. Ann For Sci 63 597-612.

Dise NB, Wright RF (1995) Nitrogen leaching from European forests in relation to nitrogen deposition. Forest Ecol Manag 71 153-161.

Dittmar Ch, Elling W (2006) Phenological phases of common beech (Fagus sylvatica L.) and their dependence on region and altitude in southern Germany. Eur J Forest Res 125 181-188.

Docherty M, Salt DT, Holopainen JK (1997) Impacts of climate change and pollution on forest insect pests. In: Forests and insects (eds Watt AD, Stork NE, Hunter MD), pp 229-247. Chapman and Hall, London.

Dorn LA, Pyle EH, Schmitt J (2000) Plasticity to light cues and resources in Arabidopsis thaliana: testing for adaptive value and costs. Evolution 54 1982-1994.

Dreyer E (1997) Photosynthesis and drought in forest trees. In: Trees - contribution to modern tree physiology (eds Rennenberg H, Eschrich W, Ziegler H), pp 215-238. Backhuys Publisher, Leiden. 
Eamus D (1996) Responses of field grown trees to $\mathrm{CO}_{2}$ enrichment. Commonw Forest Rev 75 39-47.

Eamus D (2003) How does ecosystem water balance affect net primary productivity of woody ecosystems? Funct Plant Biol 30 187-205.

Eissenstat DM (1997) Trade-offs in root form and function. In: Ecology in agriculture (ed Sackson LE), pp. 173-199. Academic Press, San Diego.

Eissenstat DM, Yanai RD (1997) The ecology of root lifespan. Adv Ecol Res 27 1-60.

Eissenstat DM, Wells CE, Yanai RD, Whitbeck JL (2000) Building roots in a changing environment: implications for root longevity. New Phytol 147 33-42.

Eissenstat DM, Yanai RD (2002) Root life span, efficiency, and turnover. In: Plant roots. The hidden half. (eds Waisel Y, Eshel A, Kafkafi U), pp. 221-238. Marcel Dekker, New York, Basel.

Eissenstat DM, Volder A (2005) The efficiency of nutrient acquisition over the life of a root. Ecol Stud 181 185-220.

Ellenberg H (1996) Vegetation Mitteleuropas mit den Alpen: In ökologischer, dynamischer und historischer Sicht. Ulmer UTB, Stuttgart, 1095 p.

Epron D, Godard D, Cornic G, Genty B (1995) Limitations of net $\mathrm{CO}_{2}$ assimilation rates by internal resistances to $\mathrm{CO}_{2}$ transfer in leaves of two species (Fagus sylvatica L. and Castanea sativa Mill.). Plant Cell Environ 18 43-51.

Eschrich W, Burchardt R, Essiamah S (1989) The induction of sun and shade leaves of the European beech (Fagus sylvatica L.): anatomical studies. Trees-Struct Funct 3 1-10.

Espeleta JF, Eissenstat DM, Graham JH (1999) Citrus root response to localized drying soil: a new approach to study mycorrhizal effects on the roots of mature trees. Plant Soil 206 1-10.

Espeleta JF, Donovan LA (2002) Fine root demography and morphology in response to soil resources availability among xeric and mesic sandhill tree species. Funct Ecol 16 113-121.

European Environment Agency EEA (2004) Impacts of Europe's changing climate. EEA, Copenhagen, $100 \mathrm{p}$.

Farquhar GD, Ehleringer JR, Hubick KT (1989) Carbon isotope discrimination and photosynthesis. Annu Rev Plant Physiol Plant Mol Biol 40 503-537.

Fernandez OA, Caldwell MM (1975) Phenology and dynamics of root growth of three cool semi-desert shrubs under field conditions. J Ecol 63 703-714.

Field CB, Jackson RB, Mooney HA (1995) Stomatal responses to increased $\mathrm{CO}_{2}$ : implications from the plant to the global scale. Plant Cell Environ 18 1214-1225.

Fischer RA, Turner NC (1978) Plant productivity in the arid and semiarid zones. Ann Rev Plant Physio 29 277-317.

Fitter AH (1994) Architecture and biomass allocation as components of the plants plastic response of root systems to soil heterogeneity. In: Exploitation of environmental heterogeneity by plants: ecophysiological process above- and belowground (eds Caldwell MM, Pearcy RW), pp. 305-323. Academic Press, San Diego.

Fort C, Fauveau ML, Muller F, Label P, Granier A, Dreyer E (1997) Stomatal conductance, growth and root signalling in young oak seedlings subjected to partial soil drying. Tree Physiol 17 281-289.

Fotelli MN, Radoglou KM, Constantinidou HIA (2000) Water stress responses of seedlings of four Mediterranean oak species. Tree Physiol 20 1065-1075. 
Fotelli MN, Rienks M, Rennenberg H, Geßler A (2004) Climate and forest management affect ${ }^{15} \mathrm{~N}$-uptake, $\mathrm{N}$ balance and biomass of European beech seedlings. Trees-Struct Funct 18 157-166.

Frech A (2006) Walddynamik in Mischwäldern des Nationalparks Hainich. Untersuchung der Mechanismen und Prognose der Waldentwicklung. PhD thesis, University of Göttingen. http://webdoc.sub.gwdg.de/diss/2006/frech/frech.pdf.

García-Plazaola JI, Becerril JM (2000) Effects of drought on photoprotective mechanisms in European beech (Fagus sylvatica L.) seedlings from different provenances. Trees-Struct Funct 14 485-490.

Gebre GM, Tschaplinski TJ, Shirshac TL (1998) Response in water relations of several hardwood species to throughfall manipulations in an upland oak forest during a wet year. Tree Physiol 18 299-305.

Gerten D, Schaphoff S, Lucht W (2007) Potential future changes in water limitations of the terrestrial biosphere. Climatic Change 80 277-299.

Geßler A, Schrempp S, Matzarakis A, Mayer H, Rennenberg H, Adams MA (2001) Radiation modifies the effect of water availability on the carbon isotope composition of beech (Fagus sylvatica). New Phytol 150 653-664.

Geßler A, Keitel C, Nahm M, Rennenberg H (2004) Water shortage affects the water and nitrogen balance in Central European beech forests. Plant Biology 6 289-298.

Geßler A, Jung K, Gasche R, Papen H, Heidenfelder A, Borner E, Metzler B, Augustin S, Hildebrand E, Rennenberg H (2005) Climate and forest management influence nitrogen balance of European beech forests: microbial $\mathrm{N}$ transformations and inorganic N net uptake capacity of mycorrhizal roots. Eur J For Res 124 95111.

Geßler A, Keitel C, Kreuzwieser J, Matyssek R, Seiler W, Rennenberg H (2007) Potential risk for European beech (Fagus sylvatica L.) in a changing climate. TreesStruct Funct 21 1-11.

Gholz HL, Ewel KC, Teskey RO (1990) Water and forest productivity. Forest Ecol Manag 30 1-18.

Gill RA, Jackson RB (2000) Global patterns of root turnover for terrestrial ecosystems. New Phytol 147 13-31.

Gillet EM (1994) GSED. Genetic structure from electrophoresis data. Version 1.0. User's manual. Institute of Forest Genetics, Göttingen, $49 \mathrm{p}$.

Gömöry D, Vysny J, Comps B, Thiebaut B (1992) Geographical patterns of genetic differentiation and diversity in European beech (Fagus sylvatica L.) populations in France. Biologia 47 571-579.

Gower ST, Vogt KA, Grier CC (1992) Carbon dynamics of Rocky Mountain Douglasfir: influence of water and nutrient availability. Ecol Monogr 62 43-65.

Grabherr G, Gottfried M, Pauli H (1994) Climate effects on mountain plants. Nature 369448.

Granier A, Biron P, Lemoine D (2000) Water balance, transpiration and canopy conductance in two beech stands. Agr Forest Meteorol 100 291-308. 
Granier $A$, Reichstein $M$, Bréda $N$, Janssens IA, Falge $E$, Ciais $P$, Grünwald $T$, Aubinet M, Berbigier P, Bernhofer C, Buchmann N, Facini O, Grassi G, Heinesch B, Ilvesniemi $H$, Keronen $P$, Knohl $A$, Köstner $B$, Lagergren $F$, Lindroth $A$, Longdoz $B$, Loustau D, Mateus J, Montagnani L, Nys C, Moors E, Papale D, Peiffer M, Pilegaard K, Pita G, Pumpanen J, Rambal S, Rebmann C, Rodrigues A, Seufert G, Tenhunen J, Vesala I, Wang Q (2007) Evidence for soil water control on carbon and water dynamics in European forests during the extremely dry year: 2003. Agr Forest Meteorol 143 123-145.

Green RN, Trowbridge RL, Klinka K (1993) Towards a taxonomic classification of humus forms. For Sci Monogr 29 1-49.

Gregorius H-R (1974) Genetischer Abstand zwischen Populationen. 1. Zur Konzeption der genetischen Abstandsmessung. Silvae Genet 23 22-27.

Gregorius H-R (1978) The concept of genetic diversity and its formal relationship to heterozygosity and genetic distance. Math Biosci 41 253-271.

Gregorius H-R, Kleinschmit JRG (1999) The environmental dichotomy of adaptation and the role of genetic diversity. Silvae Genet 48 193-199.

Gregory JM, Mitchell JFB, Brady AJ (1997) Summer drought in northern mid-latitudes in a time-dependent $\mathrm{CO}_{2}$ climate experiment. J Climate 10 662-686.

Grennfelt P, Hultberg H (1986) Effects of nitrogen deposition on the acidification of terrestrial and aquatic ecosystems. Water Air Soil Poll 30 945-963.

Grier CC, Running SW (1977) Leaf area of mature north-western coniferous forests: relation to site water balance. Ecology 58 893-899.

Grime JP, Campbell BD, Mackey JML, Crick JC (1991) Root plasticity, nitrogen capture, and competitive ability. In: Plant root growth: an ecological perspective (ed Atkinson D), pp. 381-397. Blackwell Scientific, Oxford.

Haeberli W, Beniston M (1998) Climate change and its impacts on glaciers and permafrost in the Alps. Ambio 27 258-265.

Hamilton JG, DeLucia EH, George K, Naidu SL, Finzi AC, Schlesinger WH (2002) Forest carbon balance under elevated $\mathrm{CO}_{2}$. Oecologia 131 250-260.

Hanson PJ, Weltzin JF (2000) Drought disturbance from climate change: response of United States forests. Sci Total Environ 262 205-220.

Harrington RA, Fownes JH, Meinzer FC, Scowcroft PG (1995) Forest growth along a rainfall gradient in Hawaii: Acacia koa stand structure, productivity, foliar nutrients, and water- and nutrient-use efficiencies. Oecologia 102 277-284.

Harrington RA, Fownes JH, Vitousek PM (2001) Production and resource use efficiencies in $\mathrm{N}$ - and P-limited tropical forests: a comparison of responses to longterm fertilization. Ecosystems 4 646-657.

Hayhoe K, Wake CP, Huntington TG, Luo LF, Schwartz MD, Sheffield J, Wood E, Anderson B, Bradbury J, DeGaetano A, Troy TJ, Wolfe D (2007) Past and future changes in climate and hydrological indicators in the US northeast. Clim Dynam 28 381-407.

Hazler K, Comps B, Sugar I, Melovski L, Tashev A, Gracan J (1997) Genetic structure of Fagus sylvatica L. populations in south-eastern Europe. Silvae Genet 46229 236.

Heath $\mathrm{J}$ (1998) Stomata of trees growing in $\mathrm{CO}_{2}$-enriched air show reduced sensitivity to vapour pressure deficit and drought. Plant Cell Environ 21 1077-1088. 
Heath J, Kerstiens $\mathrm{G}$ (1997) Effects of elevated $\mathrm{CO}_{2}$ on leaf gas exchange in beech and oak at two levels of nutrient supply: consequences for sensitivity to drought in beech. Plant Cell Environ 20 57-67.

Hebert MT, Jack SB (1998) Leaf area index and site water balance of Loblolly pine (Pinus taeda L.) across a precipitation gradient in east Texas. Forest Ecol Manag 105 273-282.

Heim A, Frey B (2004) Early stage litter decomposition rates for Swiss forests. Biogeochemistry 70 299-313.

Hendrick RL, Pregitzer KS (1993) The dynamics of fine root length, biomass, and nitrogen content in two northern hardwood ecosystems. Can J Forest Res 23 2507-2520.

Hendrick RL, Pregitzer KS (1996) Temporal and depth-related patterns of fine root dynamics in northern hardwood forests. J Ecol 84 167-176.

Hendrick RL, Pregitzer KS (1997) The relationship between fine root demography and the soil environment in northern hardwood forests. Ecoscience 4 99-105.

Hertel D (1999) Das Feinwurzelsystem von Rein- und Mischbeständen der Rotbuche: Struktur, Dynamik und interspezifische Konkurrenz. Gebrüder Borntraeger, Stuttgart, $190 \mathrm{p}$.

Hertel D, Leuschner Ch (2002) A comparison of four different fine root production estimates with ecosystem carbon balance data in a Fagus-Quercus mixed forest. Plant Soil 239 237-251.

Hertel H (1992) Aims and results of basic research in the Institute of Forest Tree Breeding in Waldsieversdorf, Germany. 2. The use of enzyme gene markers for practical breeding tasks. Silvae Genet 41 201-204.

Hewitt G (2000) The genetic legacy of the Quaternary ice ages. Nature 405 907-913.

Higgins PAT, Jackson RB, Des Rosiers JM, Field CB (2002) Root production and demography in a California annual grassland under elevated atmospheric carbon dioxide. Glob Change Biol 8 841-850.

Hinckley TM, Teske RO, Duhme F, Richter H (1981) Temperate hardwood forests. In: Water deficits and plant growth VI (ed Kozlowski TT), pp. 153-206. Academic Press, New York.

Hobbie EA, Tingey DT, Rygiewicz PT, Johnson MG, Olszyk DM (2002) Contributions of current year photosynthate to fine roots estimated using a ${ }^{13} \mathrm{C}$-depleted $\mathrm{CO}_{2}$ source. Plant Soil 247 233-242.

Hovenden MJ, Vander Schoor JK (2004) Nature vs. nurture in the leaf morphology of southern beech, Nothofagus cunninghamii (Nothofagaceae). New Phytol 161 585594.

Huang B, Nobel PS (1993) Hydraulic conductivity and anatomy along lateral roots of cacti - changes with soil-water status. New Phytol 123 499-507.

Hungate BA, Chapin III FS, Zhong H, Holland EA, Field CB (1997) Stimulation of grassland nitrogen cycling under carbon dioxide enrichment. Oecologia 109 149153.

Huntley B (1991) How plants respond to climatic change: migration rates, individualism and the consequences for plant communities. Ann Bot-London 67 15-22.

Idso SB (1999) The long-term response of trees to atmospheric $\mathrm{CO}_{2}$ enrichment. Glob Change Biol 5 493-495. 
International Energy Agency IEA (2005) World Energy Outlook 2005. OECD/IEA, Paris, $632 \mathrm{p}$.

IPCC (2001) Climate change 2001: the scientific basis. Contribution of working group I to the third assessment report of the Intergovernmental Panel on Climate Change. University Press, Cambridge, $944 \mathrm{p}$.

IPCC (2007) Climate change 2007: the physical basis. Summary for policymakers. Contribution of working group I to the fourth assessment report of the Intergovernmental Panel on Climate Change. http://www.ipcc.ch/SPM2feb07.pdf.

IUSS-ISRIC-FAO (2006) World reference base for soil resources 2006. A framework for international classification, correlation and communication. World Soil Resources Report 103 1-145.

Jackson PC, Meinzer FC, Bustamante M, Goldstein G, Franco A, Rundel PW, Caldas L, Igler E, Causin F (1999) Partitioning of soil water among tree species in a Brazilian Cerrado ecosystem. Tree Physiol 19 717-724.

Jackson RB, Manwaring JH, Caldwell MM (1990) Rapid physiological adjustment of roots to localized soil enrichment. Nature 344 58-60.

Jackson RB, Caldwell MM (1996) Integrating resource heterogeneity and plant plasticity: modelling nitrate and phosphate uptake in a patchy soil environment. J Ecol 84 891-903.

Jackson RB, Canadell J, Ehleringer JR, Mooney HA, Sala OE, Schulze ED (1996) A global analysis of root distributions for terrestrial biomes. Oecologia 108 389-411.

Jasieński M, Ayala FJ, Bazzaz FA (1997) Phenotypic plasticity and similarity of DNA among genotypes of an annual plant. Heredity 78 176-181.

Jenny H (1941) Factors in soil formation. McGraw-Hill, New York, 281 p.

Johnson DW, Hanson PJ, Todd DE, Susfalk RB, Trettin CF (1998) Precipitation change and soil leaching: field results and simulations from Walker Branch Watershed, Tennessee. Water Air Soil Poll 105 251-262.

Jones MD, Durall DM, Cairney WG (2003) Ectomycorrhizal fungal communities in young forest stands regenerating after clearcut logging. New Phytol 157 399-422.

Jose S, Gillespie R (1997) Leaf area-productivity relationships among mixed-species hardwood forest communities of the central hardwood region. Forest Sci 43 56-64.

Joslin JD, Wolfe MH (1998) Impacts of water input manipulations on fine root production and mortality in a mature hardwood forest. Plant Soil 204 165-174.

Joslin JD, Wolfe MH, Hanson PJ (2000) Effects of altered water regimes on forest root systems. New Phytol 147 117-129.

Joslin JD, Wolfe MH, Hanson PJ (2001) Factors controlling the timing of root elongation intensity in a mature upland oak stand. Plant Soil 228 201-212.

Joughin I, Abdalati W, Fahnestock M (2004) Large fluctuations in speed on Greenland's Jakobshavn Isbrae glacier. Nature 432 608-610.

Kellomäki S, Vaisanen H (1997) Modelling the dynamics of the forest ecosystem for climate change studies. Ecol Model 97 121-140.

Kembel SW, Cahill JF (2005) Plant phenotypic plasticity belowground: a phylogenetic perspective on root foraging trade-offs. Am Nat 166 216-230.

Khalil AAM, Grace J (1992) Acclimation to drought in Acer pseudoplatanus L. (Sycamore) seedlings. J Exp Bot 43 1591-1602. 
Kim GT, Yano S, Kozuka T, Tsukaya H (2005) Photomorphogenesis of leaves: shadeavoidance and differentiation of sun and shade leaves. Photoch Photobio S 4 770774.

Kimball BA, Lamorte RL, Pinter PJ, Wall GW, Hunsaker DJ, Adamsen FJ, Leavitt SW, Thompson TL, Matthias AD, Brooks TJ (1999) Free-air $\mathrm{CO}_{2}$-enrichment and soil nitrogen effects on energy balance and evapotranspiration of wheat. Water Resour Res 35 1179-1190.

Kirschbaum MUF (1995) The temperature dependence of soil organic matter decomposition, and the effect of global warming on soil organic $\mathrm{C}$ storage. Soil Biol Biochem 27 753-760.

Koerselman W, Meuleman AFM (1996) The vegetation N:P ratio: a new tool to detect the nature of nutrient limitation. J Appl Ecol 33 1441-1450.

Kohler M, Köckemann B, Peichl M, Schmitt J, Reif A (2006) Impacts of the drought 2003 on the crown condition of suppressed and intermediate beech trees (Fagus sylvatica L.) at the ecotone between beech and downy oak forest in the nature reserve Innerberg, Südbaden. Allg Forst Jagdztg 177 86-91.

Konnert M (1995) Investigations on the genetic variation of beech (Fagus sylvatica L.) in Bavaria. Silvae Genet 44 346-351.

Körner C (2003) Carbon limitation in trees. J Ecol 91 4-17.

Körner C, Bannister P, Mark AF (1986) Altitudinal variation in stomatal conductance, nitrogen content and leaf anatomy in different plant life forms in New Zealand. Oecologia 69 577-588.

Körner C, Asshoff R, Bignucolo O, Hättenschwiler S, Keel SG, Peláez-Riedl S, Pepin S, Siegwolf RTW, Zotz G (2005) Carbon flux and growth in mature deciduous forest trees exposed to elevated $\mathrm{CO}_{2}$. Science 309 1360-1362.

Kossuth SV, Ross SD (1987) Hormonal control of tree growth. Plant Growth Regul 6 1-215.

Kozlowski TT, Kramer PJ, Pallardy SG (1991) The physiological ecology of woody plants. Academic Press, San Diego, 657 p.

Kozlowski TT, Pallardy SG (2002) Acclimation and adaptive responses of woody plants to environmental stresses. Bot Rev 68 270-334.

Kuhns MR, Garrett HE, Teskey RO, Hinckley TM (1985) Root growth of black walnut trees related to soil temperature, soil water potential, and leaf water potential. Forest Sci 31 617-629.

Kullman L (2001) $20^{\text {th }}$ century climate warming and tree-limit rise in the southern Scandes of Sweden. Ambio 30 72-80.

Kummerow J, Krause D, Jow W (1978) Seasonal changes of fine root density in the southern Californian Chaparral. Oecologia 37 201-212.

Kundzewicz ZW, Radziejewski M, Pinskwar I (2006) Precipitation extremes in the changing climate of Europe. Climate Res 31 51-58.

Kunstmann H, Schneider K, Forkel R, Knoche R (2004) Impact analysis of climate change for an Alpine catchment using high resolution dynamic downscaling of ECHAM4 time slices. Hydrol Earth Syst Sc 8 1030-1044.

Kutschera L, Lichtenegger E (2002) Wurzelatlas mitteleuropäischer Waldbäume und Sträucher. Stocker, Graz, 604 p.

Lauenroth WK, Gill R (2003) Turnover of root systems. In: Root ecology. Ecological Studies 168 (eds de Kroon H, Visser EJW), pp 61-90. Springer, Berlin. 
Law BE, Falge E, Gu L, Baldocchi DD, Bakwin P, Berbigier P, Davis K, Dolman AJ, Falk M, Fuentes JD, Goldstein A, Granier A, Grelle A, Hollinger D, Janssens IA, Jarvis $P$, Jensen NO, Katul G, Mahli Y, Matteucci G, Meyers T, Monson R, Munger W, Oechel W, Olson R, Pilegaard K, Paw KT, Thorgeirsson H, Valentini R, Verma S, Vesala T, Wilson K, Wofsy S (2002) Environmental controls over carbon dioxide and water vapour exchange of terrestrial vegetation. Agr Forest Meteorol 113 97-120.

Le Dantec V, Dufrêne E, Saugier B (2000) Interannual and spatial variation in maximum leaf area index of temperate deciduous stands. Forest Ecol Manag 134 71-81.

Lebaube S, Le Goff N, Ottorini J-M, Granire A (2000) Carbon balance and tree growth in a Fagus sylvatica stand. Ann Forest Sci 57 49-61.

Lebourgeois F, Bréda N, Ulrich E, Granier A (2005) Climate-tree-growth relationships of European beech (Fagus sylvatica L.) in the French Permanent Plot Network (RENECOFOR). Trees-Struct Funct 19 385-401.

Lee DH, Veizer J (2003) Water and carbon cycles in the Mississippi River basin: potential implications for the northern hemisphere residual terrestrial sink. Global Biogeochem Cy 171037.

Leuschner Ch, Backes K, Hertel D, Schipka F, Schmitt U, Terborg O, Runge M (2001a) Drought responses at leaf, stem and fine root levels of competitive Fagus sylvatica L. and Quercus petraea (Matt.) Liebl. trees in dry and wet years. Forest Ecol Manag 149 33-46.

Leuschner Ch, Hertel D, Coners H, Büttner V (2001b) Root competition between beech and oak: a hypothesis. Oecologia 126 276-284.

Leuschner Ch, Coners H, Icke R, Hartmann K, Effinger ND, Schreiber L (2003) Chemical composition of the periderm in relation to in situ water absorption rates of oak, beech and spruce fine roots. Ann For Sci 60 763-772.

Leuschner Ch, Hertel D (2003) Fine root biomass of temperate forests in relation to soil acidity and fertility, climate, age and species. In: Progress in botany 64 (eds Esser K, Lüttge U, Beyschlag W, Hellwig F), pp. 405-438. Springer, Berlin, Heidelberg.

Leuschner Ch, Hertel D, Schmid I, Koch O, Muhs A, Hölscher D (2004) Stand fine root biomass and fine root morphology in old-growth beech forests as a function of precipitation and soil fertility. Plant Soil 258 43-56.

Leuschner Ch, Meier IC, Hertel D (2006a) On the niche breadth of Fagus sylvatica: soil nutrient status in 50 Central European beech stands on a broad range of bedrock types. Ann Forest Sci 63 355-368.

Leuschner Ch, Voss S, Foetzki A, Clases Y (2006b) Variation in leaf area index and stand leaf mass of European beech across gradients of soil acidity and precipitation. Plant Ecol 186 247-258.

Liengsiri C, Piewluang C, Boyle TJB (1990) Starch gel electrophoresis of tropical trees. A manual. ASEAN-Canada Forest Tree Seed Centre and Petawawa National Forestry Institute, Bangkok, Thailand, $51 \mathrm{p}$.

Lindner M, Cramer W (2002) German forest sector under global change: an interdisciplinary impact assessment. Forstwiss Centralbl 121 3-17.

Lindroth RL, Kinney KK, Platz CL (1993) Responses of deciduous trees to elevated atmospheric $\mathrm{CO}_{2}$ : productivity, phytochemistry, and insect performance. Ecology 74 763-777. 
Lockwood JG (1999) Is potential evapotranspiration and its relationship with actual evapotranspiration sensitive to elevated atmospheric $\mathrm{CO}_{2}$ levels? Climatic Change 41 193-212.

Löf M, Welander NT (2000) Carry-over effects on growth and transpiration in Fagus sylvatica seedlings after drought at various stages of development. Can $\mathrm{J}$ Forest Res 30 468-475.

Lovett GM, Lindberg SE (1993) Atmospheric deposition and canopy interactions of nitrogen in forests. Can J Forest Res 23 1603-1616.

Lu ZJ, Neumann PM (1998) Water-stressed maize, barley and rice seedlings show species diversity in mechanisms of leaf growth inhibition. J Exp Bot 49 1945-1952.

Lux A, Luxova M, Hattori T, Inanaga S, Sugimoto Y (2002) Silicification in sorghum (Sorghum bicolor) cultivars with different drought tolerance. Physiol Plantarum 115 87-92.

Lyr H, Hoffmann G (1967) Growth rates and growth periodicity of tree roots. Int Rev For Res 2 181-236.

Magnani F, Borhetti M (1995) Interpretation of seasonal changes of xylem embolism and plant hydraulic resistance in Fagus sylvatica. Plant Cell Environ 18 689-696.

Magri D, Vendramin GG, Comps B, Dupanloup I, Geburek T, Gömöry D, Latalowa M, Litt T, Paule L, Roure JM, Tantau I, van der Knaap WO, Petit RJ, de Beaulieu JL (2006) A new scenario for the Quaternary history of European beech populations: palaeobotanical evidence and genetic consequences. New Phytol 171 199-221.

Maherali H, DeLucia E (2001) Influence of climate-driven shifts in biomass allocation on water transport and storage in Ponderosa pine. Oecologia 129 481-491.

Majdi H, Kangas P (1997) Demography of fine roots in response to nutrient applications in a Norway spruce stand in south-western Sweden. Ecoscience 4 199-205.

Majdi H, Pregitzer K, Moren AS, Nylund JE, Agren GI (2005) Measuring fine root turnover in forest ecosystems. Plant Soil 276 1-8.

Makkonen K, Helmisaari HS (1999) Assessing fine-root biomass and production in a Scots pine stand - comparison of soil core and root ingrowth core methods. Plant Soil $21043-50$.

Masiokas M, Villalba R (2004) Climatic significance of intra-annual bands in the wood of Nothofagus pumilio in southern Patagonia. Trees-Struct Funct 18 696-704.

Medlyn BE, Barton CVM, Broadmeadow MSJ, Ceulemans R, De Angelis P, Forstreuter M, Freeman M, Jackson SB, Kellomaki S, Laitat E, Rey A, Roberntz P, Sigurdsson BD, Strassemeyer J, Wang K, Curtis PS, Jarvis PG (2001a) Stomatal conductance of forest species after long-term exposure to elevated $\mathrm{CO}_{2}$ concentration: a synthesis. New Phytol 149 247-264.

Medlyn BE, Rey A, Barton CVM, Forstreuter M (2001b) Above-ground growth responses of forest trees to elevated atmospheric $\mathrm{CO}_{2}$-concentrations. In: The impact of carbon dioxide and other greenhouse gases on forest ecosystems (eds Karnosky DF, Ceulemans R, Scarascia-Mugnozza GE, Innes JL), pp. 127-146. CAB International.

Mencuccini M, Grace J (1994) Climate influences the leaf area/sapwood area ratio in Scots pine. Tree Physiol 15 1-10.

Meshinev T, Apostolova I, Koleva E (2000) Influence of warming on timberline rising: a case study on Pinus peuce Griseb. in Bulgaria. Phytocoenologia 30 431-438. 
Milthorpe FL, Newton P (1963) Studies on expansion of leaf surface. 3. Influence of radiation on cell division and leaf expansion. J Exp Bot 14483.

Mooney HA, Drake BG, Luxmoore RJ, Oechel WC, Pitelka LF (1991) Predicting ecosystem responses to elevated $\mathrm{CO}_{2}$ concentrations. Bioscience 41 96-104.

Müller-Stark R (1996) Genetische Aspekte der Reproduktion der Buche (Fagus sylvatica L.) unter Berücksichtigung waldbaulicher Gegebenheiten. Berichte des Forschungszentrums Waldökosysteme A135, Göttingen, 103 p.

Munné-Bosch S, Alegre L (2004) Die and let live: leaf senescence contributes to plant survival under drought stress. Funct Plant Biol 31 203-216.

Murphy J, Riley JP (1962) A modified single-solution method for determination of phosphate in natural waters. Anal Chim Acta 27 31-36.

Nadelhoffer KJ, Raich JW (1992) Fine root production estimates and belowground carbon allocation in forest ecosystems. Ecology 73 1139-1147.

Neill C (1992) Comparison of soil coring and ingrowth methods for measuring belowground production. Ecology 73 1918-1921.

Nemani R, White M, Thornton P, Nishida K, Reddy S, Jenkins J, Running S (2002) Recent trends in hydrologic balance have enhanced the terrestrial carbon sink in the United States. Geophys Res Lett 291468.

Nepstad DC, de Carvalho CR, Davidson EA, Jipp PH, Lefebvre PA, Negreiros GH, Da Silva ED, Stone TA, Trumbore SE, Vieira S (1994) The role of deep roots in the hydrological and carbon cycles of Amazonian forests and pastures. Nature 372 666-669.

Newman El (1995) Phosphorus inputs to terrestrial ecosystems. J Ecol 83 713-726.

Nihlgård B, Lindgren L (1977) Plant biomass, primary production and bioelements of three mature beech forests in south Sweden. Oikos 28 95-104.

Nisbeth TR, Mullins CE (1986) A comparison of live and dead root weights in stands of Sitka spruce in contrasting soil water regimes. Can J Forest Res 16 394-397.

Norby RJ, Hanson PJ, O'Neill EG, Tschaplinski TJ, Weltzin JF, Hansen RA, Cheng WX, Wullschleger SD, Gunderson CA, Edwards NT, Johnson DW (2002) Net primary productivity of a $\mathrm{CO}_{2}$-enriched deciduous forest and the implications for carbon storage. Ecol Appl 12 1261-1266.

Norby RJ, Luo $\mathrm{Y}$ (2004) Evaluating ecosystem responses to rising atmospheric $\mathrm{CO}_{2}$ and global warming in a multi-factor world. New Phytol 162 281-293.

Otieno DO, Schmidt MWT, Adiku S, Tenhunen J (2005) Physiological and morphological responses to water stress in two Acacia species from contrasting habitats. Tree Physiol 25 361-371.

Pallardy SG, Rhoads JL (1993) Morphological adaptations to drought in seedlings of deciduous angiosperms. Can J Forest Res 23 1766-1774.

Parkhurst DF, Loucks OL (1972) Optimal leaf size in relation to environment. J Ecol 60 505-537.

Parmesan C, Yohe G (2003) A globally coherent fingerprint of climate change impacts across natural systems. Nature 421 37-42.

Pedrol N, Ramos P, Reigosa MJ (2000) Phenotypic plasticity and acclimation to water deficits in velvet-grass: a long-term greenhouse experiment. Changes in leaf morphology, photosynthesis and stress-induced metabolites. J Plant Physiol 157 383-393. 
Peñuelas J, Boada M (2003) A global change-induced biome shift in the Montseny mountains (NE Spain). Glob Change Biol 9 131-140.

Persson H (1978) Root dynamics in a young Scots pine stand in central Sweden. Oikos 30 508-519.

Persson H, von Fircks Y, Majdi H, Nilsson LO (1995) Root distribution in a Norway spruce (Picea abies (L.) Karst) stand subjected to drought and ammonium-sulphate application. Plant Soil 168-169 161-165.

Peuke AD, Geßler A, Rennenberg H (2006) The effect of drought on C and N stable isotopes in different fractions of leaves, stems and roots of sensitive and tolerant beech ecotypes. Plant Cell Environ 29 823-835.

Pigliucci M (2001) Phenotypic plasticity: beyond nature and nurture. Syntheses in ecology and evolution. Johns Hopkins University Press, Baltimore, 344 p.

Pigott CD, Pigott S (1993) Water as determinant of the distribution of trees at the boundary of the Mediterranean zone. J Ecol 91 557-566.

Pockman WT, Sperry JS (2000) Vulnerability to xylem cavitation and the distribution of Sonoran desert vegetation. Am J Bot 87 1287-1299.

Polley HW, Johnson HB, Tischler CR (2003) Woody invasion of grasslands: evidence that $\mathrm{CO}_{2}$ enrichment indirectly promotes establishment of Prosopis glandulosa. Plant Ecol 164 85-94.

Poorter H (1989) Interspecific variation in relative growth rate: on ecological causes and physiological consequences. In: Causes and consequences of variation in growth rate and productivity of higher plants (eds Lambers $\mathrm{H}$, Cambridge ML, Konings H, Pons TL), pp. 45-68. SPB Academic, The Hague.

Poorter H, Lambers $\mathrm{H}$ (1986) Growth and competitive ability of a highly plastic and a marginally plastic genotype of Plantago major in a fluctuating environment. Physiol Plantarum 67 217-222.

Pregitzer KS (2002) Fine roots of trees - a new perspective. New Phytol 154 267273.

Pregitzer KS, Hendrick RL, Fogel R (1993) The demography of fine roots in response to patches of water and nitrogen. New Phytol 125 575-580.

Pregitzer KS, Laskowski MJ, Burton AJ, Lessard VC, Zak DR (1998) Variation in Sugar maple root respiration with root diameter and soil depth. Tree Physiol 18 665-670.

Pregitzer KS, DeForest JL, Burton AJ, Allen MF, Ruess RW, Hendrick RL (2002) Fine root architecture of nine North American trees. Ecol Monogr 72 293-309.

Prior LD, Bowman DMJS, Eamus D (2005) Intra-specific variation in leaf attributes of four savanna tree species across a rainfall gradient in tropical Australia. Aust $\mathrm{J} B o t$ 53 323-335.

Quilchano C, Egido JA, Gonzalez MI (1995) Climate sequence of soils developed on granites in the Sierra de Gata, Salamanca, Spain. Arid Soil Res Rehab 9 385-397.

Radin JW, Boyer JS (1982) Control of leaf expansion by nitrogen nutrition in sunflower plants - role of hydraulic conductivity and turgor. Plant Physiol 69 771-775.

Raich JW, Parton WJ, Russell AE, Sanford RL, Vitousek PM (2000) Analysis of factors regulating ecosystem development on Mauna Loa using the Century model. Biogeochemistry 51 161-191. 
Reich PB, Ellsworth DS, Walters MB, Vose JM, Gresham C, Volin JC, Bowman WD (1999) Generality of leaf trait relationships: a test across six biomes. Ecology $\mathbf{8 0}$ 1955-1969.

Reich PB, Oleksyn J (2004) Global patterns of plant leaf $N$ and $P$ in relation to temperature and latitude. P Natl Acad Sci USA 101 11001-11006.

Relyea RA (2002) Costs of phenotypic plasticity. Am Nat 159 272-282.

Richards JH, Caldwell MM (1987) Hydraulic lift - substantial nocturnal water transport between soil layers by Artemisia tridentata roots. Oecologia 73 486-489.

Rignot E (2006) Changes in ice dynamics and mass balance of the Antarctic ice sheet. Philos T R Soc A 364 1637-1655.

Rothe A, Huber C, Kreutzer K, Weis W (2002) Deposition and soil leaching in stands of Norway spruce and European beech: results from the Hoglwald research in comparison with other European case studies. Plant Soil 240 33-45.

Rouault G, Candau JN, Lieutier F, Nageleisen LM, Martin JC, Warzee N (2006) Effects of drought and heat on forest insect populations in relation to the 2003 drought in western Europe. Ann For Sci 63 613-624.

Rowell DP, Jones RG (2006) Causes and uncertainty of future summer drying over Europe. Clim Dynam 27 281-299.

Runyon J, Waring RH, Goward SN, Welles JM (1994) Environmental limits on net primary production and light-use efficiency across the Oregon transect. Ecol Appl 4 226-237.

Rustad LE, Campbell JL, Marion GM, Norby RJ, Mitchell MJ, Hartley AE, Cornelissen JHC, Gurevitch J (2001) A meta-analysis of the response of soil respiration, net nitrogen mineralization, and aboveground plant growth to experimental ecosystem warming. Oecologia 126 543-562.

Ryser P (1996) The importance of tissue density for growth and life span of leaves and roots: a comparison of five ecologically contrasting grasses. Funct Ecol 10717 723.

Sack L, Melcher PJ, Liu WH, Middleton E, Pardee T (2006) How strong is intracanopy leaf plasticity in temperate deciduous trees? Am J Bot 93 829-839.

Sandstrom K (1995) Modelling the effects of rainfall variability on groundwater recharge in semi-arid Tanzania. Nord Hydrol 26 313-330.

Santantonio D, Hermann RK (1985) Standing crop, production, and turnover of fine roots on dry, moderate, and wet sites of mature Douglas-fir in western Oregon. Ann Sci Forest 42 113-142.

Santrucek J, Sage RF (1996) Acclimation of stomatal conductance to a $\mathrm{CO}_{2}$-enriched atmosphere and elevated temperature in Chenopodium album. Aust J Plant Physiol 23 467-478.

Scheiner SM (1993) Plasticity as a selectable trait - reply. Am Nat 142 371-373.

Schipka F (2003) Blattwasserzustand und Wasserumsatz von vier Buchenwäldern entlang eines Niederschlagsgradienten in Mitteldeutschland. PhD thesis, University of Göttingen. http://webdoc.sub.gwdg.de/diss/2003/schipka.

Schipka F, Heimann J, Leuschner C (2005) Regional variation in canopy transpiration of Central European beech forests. Oecologia 143 260-270.

Schlichting CD (1986) The evolution of phenotypic plasticity in plants. Ann Rev Ecol Syst 17 667-693. 
Schlichting CD, Pigliucci M (1993) Control of phenotypic plasticity via regulatory genes. Am Nat 142 366-370.

Schönwiese C-D, Bader S, Böhm R, Claussen M, Cubasch U, Fischer H, Gärtner U, Graßl H, Rahmstorf S, Sündermann J, Claussen M, Kromp-Kolb H, Richner H (2003) Klimastatement 2003 der Deutschen Meteorologischen Gesellschaft (DMG), der Österreichischen Gesellschaft für Meteorologie (ÖGM) und der Schweizerischen Gesellschaft für Meteorologie (SGM). http://www.dmg-ev.de/gesellschaft/ aktivitaeten/pdf/klimastatement_2003.pdf.

Sellers PJ, Bounoua L, Collatz GJ, Randall DA, Dazlich DA, Los SO, Berry JA, Fung I, Tucker CJ, Field CB, Jensen TG (1996) Comparison of radiative and physiological effects of doubled atmospheric $\mathrm{CO}_{2}$ on climate. Science 271 1402-1406.

Sibbesen E (1977) A simple ion-exchange resin procedure for extracting plantavailable elements from soil. Plant Soil 46 665-669.

Singh H, Singh KP (1994) Nitrogen and phosphorus availability and mineralization in dryland reduced tillage cultivation - effects of residue placement and chemical fertilizer. Soil Biol Biochem 26 695-702.

Spinnler D, Körner C (2002) Four-year growth dynamics of beech-spruce model ecosystems under $\mathrm{CO}_{2}$ enrichment on two different forest soils. Trees-Struct Funct 16 423-436.

Stark JM (1994) Causes of soil heterogeneity at different scales. In: Exploitation of environmental heterogeneity at different scales (eds Caldwell M, Pearcy R), pp. 255284. Academic Press, New York.

Steele SJ, Gower ST, Vogel JG, Norman JM (1997) Root mass, net primary production and turnover in aspen, Jack pine and black spruce forests in Saskatchewan and Manitoba, Canada. Tree Physiol 17 577-587.

Stefancik I (1997) Phenology of beech (Fagus sylvatica) in two different localities in central Slovakia. Biologia 52 33-40.

Sultan SE (2001) Phenotypic plasticity for fitness components in Polygonum species of contrasting ecological breadth. Ecology 82 328-343.

Tardieu F, Granier C, Muller B (1999) Modelling leaf expansion in a fluctuating environment: are changes in specific leaf area a consequence of changes in expansion rate? New Phytol 143 33-44.

Terborg O (1998) Die Kohlenstoffassimilation von Rotbuchen und Traubeneichen in einem Mischbestand in der Lüneburger Heide und deren Bedeutung für die interspezifische Konkurrenz. PhD thesis, University of Göttingen, 109 p.

Teskey RO, Hinckley TM (1981) Influence of temperature and water potential on root growth of white oak. Physiol Plantarum 52 363-369.

Thornley JHM, Cannell MGR (1996) Temperate forest responses to carbon dioxide, temperature and nitrogen: a model analysis. Plant Cell Environ 19 1331-1348.

Thuiller W, Lavorel S, Midgley G, Lavergne S, Rebelo T (2004) Relating plant traits and species distributions along bioclimatic gradients for 88 Leucadendron taxa. Ecology 85 1688-1699.

Tisdale SL, Nelson WL, Beaton JD (1985) Soil fertility and fertilizers. Macmillan, New York, $754 \mathrm{p}$.

Tjoelker MG, Craine JM, Wedin D, Reich PB, Tilman D (2005) Linking leaf and root trait syndromes among 39 grassland and savannah species. New Phytol 167 493508. 
Tognetti R, Johnson JD, Michelozzi M (1995) The response of European beech (Fagus sylvatica L.) seedlings from two Italian populations to drought and recovery. Trees-Struct Funct 9 348-354.

Torrecillas A, Galego R, Pérez-Pastor A, Ruiz-Sánchez MC (1999) Gas exchange and water relations of young apricot plants under drought conditions. J Agr Sci 132 445-452.

Trömel S, Schönwiese C-D (2007) Probability change of extreme precipitation observed from 1901 to 2000 in Germany. Theor Appl Climatol 87 29-39.

Tschaplinski TJ, Stewart DB, Hanson PJ, Norby RJ (1995) Interactions between drought and elevated $\mathrm{CO}_{2}$ on growth and gas exchange of seedlings of three deciduous tree species. New Phytol 129 63-71.

Tschaplinski TJ, Gebre GM, Shirshac TL (1998) Osmotic potential of several hardwood species as affected by manipulation of throughfall precipitation in an upland oak forest during a dry year. Tree Physiol 18 291-298.

Tuomi J, Niemalä P, Chapin III FS, Bryant JP, Sirin S (1988) Defensive responses of trees in relation to their carbon/nutrient balance. In: Mechanisms of woody plant defences against insects. Search for pattern (eds Mattson WJ, Levieux J, BernardDagan C), pp. 57-72. Springer, New York.

Turner IM (1994) A quantitative analysis of leaf form in woody plants from the world's major broadleaved forest types. J Biogeogr 21 413-419.

Tyree MT, Hammel HT (1972) The measurement of the turgor pressure and the water relations of plants by the pressure-bomb technique. J Exp Bot 23 267-282.

Tyree MT, Velez V, Dalling JW (1998) Growth dynamics of root and shoot hydraulic conductance in seedlings of five neotropical tree species: scaling to show possible adaptation to differing light regimes. Oecologia 114 293-298.

Ukonmaanaho L, Starr M (2002) Major nutrients and acidity: budgets and trends at four remote boreal stands in Finland during the 1990s. Sci Total Environ 29721 41.

Valladares F, Sanchez-Gomez D, Zavala MA (2006) Quantitative estimation of phenotypic plasticity: bridging the gap between the evolutionary concept and its ecological applications. J Ecol 94 1103-1116.

Van der Krift TAJ, Berendse F (2001) The effect of plant species on soil nitrogen mineralization. J Ecol 89 555-561.

Van der Werf A, Nagel OW (1996) Carbon allocation to shoots and roots in relation to nitrogen supply is mediated by cytokinins and sucrose: opinion. Plant Soil 185 2132.

Van Hees AFM (1997) Growth and morphology of pedunculate oak (Quercus robur L.) and beech (Fagus sylvatica L.) seedlings in relation to shading and drought. Ann Sci Forest 54, 9-18.

Van Praag HJ, Sougnez-Remy S, Weissen F, Carletti G (1987) Root turnover in a beech and spruce stand of the Belgian Ardennes. Plant Soil 105 87-103.

Van Tienderen PH (1991) Evolution of generalists and specialists in spatially heterogeneous environments. Evolution 45 1317-1331.

Van Volkenburgh E (1999) Leaf expansion - an integrating plant behaviour. Plant Cell Environ 22 1463-1473.

Via S (1993) Adaptive phenotypic plasticity - target or by-product of selection in a variable environment. Am Nat 142 352-365. 
Vogt KA, Vogt DJ, Palmiotto PA, Boon P, O'Hara J, Asbjornsen H (1996) Review of root dynamics in forest ecosystems grouped by climate, climatic forest type and species. Plant Soil 187 159-219.

Volder A, Smart DR, Bloom AJ, Eissenstat DM (2004) Rapid decline in nitrate uptake and respiration with age in fine lateral roots of grape: implications for root efficiency and competitive effectiveness. New Phytol 165 493-502.

Wahl S, Ryser P (2000) Root tissue structure is linked to ecological strategies of grasses. New Phytol 148 459-471.

Wang K-S (2001) Gene flow and mating system in European beech (Fagus sylvatica L.). Cuvillier-Verlag, Göttingen, 159 p.

Wang K-S (2003) Genetic diversity and temporal genetic structure in European beech (Fagus sylvatica L.). Silvae Genet 52 100-106.

Welander NT, Ottosson B (1997) Influence of photosynthetic photon flux density on growth and transpiration in seedlings of Fagus sylvatica. Tree Physiol 17 133-140.

Wells CE, Eissenstat DM (2001) Marked differences in survivorship among apple roots of different diameters. Ecology 82 882-892.

Wells CE, Glenn DM, Eissenstat DM (2002) Soil insects alter fine root demography in peach (Prunus persica). Plant Cell Environ 25 431-439.

Wells CE, Eissenstat DM (2003) Beyond the roots of young seedlings: the influence of age and order on fine root physiology. J Plant Growth Regul 21 324-334.

Wetherald RT, Manabe S (2002) Simulation of hydrologic changes associated with global warming. J Geophys Res-Atmos 107 (D19).

Wilson K, Gunn A, Cherrett JM (1995) The application of a rhizotron to study the subterranean effects of pesticides. Pedobiologia 39 132-143.

Withington JM, Reich PB, Oleksyn J, Eissenstat DM (2006) Comparisons of structure and life span in roots and leaves among temperate trees. Ecol Monogr 76 381-397.

Wright IJ, Reich PB, Westoby M, Ackerly DD, Baruch Z, Bongers F, Cavender-Bares J, Chapin T, Cornelissen JHC, Diemer M, Flexas J, Garnier E, Groom PK, Gulias J, Hikosaka K, Lamont BB, Lee T, Lee W, Lusk C, Midgley JJ, Navas ML, Niinemets U, Oleksyn J, Osada N, Poorter H, Poot P, Prior L, Pyankov VI, Roumet C, Thomas SC, Tjoelker MG, Veneklaas EJ, Villar R (2004) The worldwide leaf economics spectrum. Nature 428 821-827.

Wullschleger SD, Hanson PJ, Tschaplinski TJ (1998) Whole-plant water flux in understory red maple exposed to altered precipitation regimes. Tree Physiol 18 7179.

Wullschleger SD, Hanson PJ (2006) Sensitivity of canopy transpiration to altered precipitation in an upland oak forest: evidence from a long-term field manipulation study. Glob Change Biol 12 97-109.

Xiao JF, Moody A (2004) Photosynthetic activity of US biomes: responses to the spatial variability and seasonality of precipitation and temperature. Glob Change Biol 10 437-451.

Yang YH, Watanabe M, Wang ZP, Sakura Y, Tang CY (2003) Prediction of changes in soil moisture associated with climatic changes and their implications for vegetation changes: waves model simulation on Taihang Mountain, China. Climatic Change 57 163-183.

Yavitt JB, Wright SJ (1996) Temporal patterns of soil nutrients in a Panamanian moist forest revealed by ion-exchange resin and experimental irrigation. Plant Soil 183 117-129. 
Zak DR, Pregitzer KS, Curtis PS, Teeri JA, Fogel R, Randlett DL (1993) Elevated atmospheric $\mathrm{CO}_{2}$ and feedback between carbon and nitrogen cycles. Plant Soil 151 105-117. 
Appendix 
Table A1. Some chemical properties of the organic layer and the mineral soil of 14 beech stands on Triassic sandstone along a precipitation gradient in central Germany (mean of five samples per study site). Values relate to the entire organic layer (L, F, H layers) or the mineral soil in $0-20 \mathrm{~cm}$ depth.

\begin{tabular}{|c|c|c|c|c|c|c|c|c|c|c|c|c|c|c|c|}
\hline & Site\# & 1 & 2 & 3 & 4 & 5 & 6 & 7 & 8 & 9 & 10 & 11 & 12 & 13 & 14 \\
\hline Precipitation & {$\left[\mathrm{mm} \mathrm{yr}^{-1}\right]$} & 970 & 950 & 910 & 860 & 820 & 800 & 680 & 670 & 650 & 580 & 580 & 550 & 550 & 520 \\
\hline \multicolumn{16}{|l|}{ organic layer } \\
\hline Organic matter & {$\left[\mathrm{kg} \mathrm{m}^{-2}\right]$} & 3.0 & 6.2 & 2.7 & 6.2 & 7.6 & 2.0 & 1.9 & 1.7 & 1.7 & 2.4 & 3.2 & 3.4 & 2.9 & 3.3 \\
\hline $\mathrm{C}_{\text {org }}$ & {$\left[\mathrm{mol} \mathrm{m}^{-2}\right]$} & 100 & 214 & 77 & 159 & 304 & 53 & 48 & 48 & 48 & 53 & 75 & 64 & 71 & 69 \\
\hline $\mathrm{N}_{\mathrm{t}}$ & {$\left[\mathrm{mol} \mathrm{m}^{-2}\right]$} & 3.9 & 9.0 & 3.0 & 6.1 & 12.8 & 2.3 & 1.8 & 1.6 & 1.7 & 1.7 & 2.9 & 2.5 & 2.7 & 2.8 \\
\hline $\mathrm{C} / \mathrm{N}$ & {$\left[\mathrm{mol} \mathrm{mol}^{-1}\right]$} & 25.6 & 24.0 & 25.4 & 25.6 & 23.7 & 23.1 & 26.8 & 29.6 & 28.2 & 30.4 & 25.9 & 25.8 & 26.1 & 24.3 \\
\hline $\mathrm{pH}\left(\mathrm{H}_{2} \mathrm{O}\right)$ & & 4.7 & 4.4 & 5.3 & 5.1 & 4.6 & 5.9 & 5.6 & 5.1 & 5.8 & 5.7 & 4.8 & 4.9 & 5.9 & 5.8 \\
\hline $\mathrm{P}_{\mathrm{t}}$ & {$\left[\mathrm{mmol} \mathrm{m} \mathrm{m}^{-2}\right]$} & 198 & 247 & 127 & 239 & 464 & 82 & 74 & 77 & 82 & 115 & 131 & 121 & 120 & 143 \\
\hline $\mathrm{C} / \mathrm{P}$ & {$\left[\mathrm{mol} \mathrm{mol}^{-1}\right]$} & 505 & 837 & 596 & 651 & 615 & 619 & 653 & 607 & 586 & 462 & 589 & 531 & 576 & 483 \\
\hline$N / P$ & {$\left[\mathrm{~mol} \mathrm{~mol}^{-1}\right]$} & 19.8 & 34.9 & 23.6 & 25.5 & 26.2 & 26.6 & 24.3 & 20.5 & 20.8 & 15.2 & 22.7 & 20.6 & 22.0 & 19.9 \\
\hline $\mathrm{C} / \mathrm{Mg}$ & {$\left[\mathrm{mol} \mathrm{mol}^{-1}\right]$} & 855 & 1413 & 230 & 454 & 659 & 189 & 537 & 628 & 324 & 253 & 704 & 410 & 485 & 461 \\
\hline $\mathrm{C} / \mathrm{K}$ & {$\left[\mathrm{mol} \mathrm{mol}^{-1}\right]$} & 469 & 755 & 419 & 353 & 356 & 176 & 269 & 341 & 279 & 149 & 350 & 218 & 321 & 296 \\
\hline$(\mathrm{Ca}+\mathrm{Mg}+\mathrm{K})_{\mathrm{t}}$ & {$\left[\mathrm{mmol} \mathrm{m} \mathrm{m}^{-2}\right]$} & 753 & 795 & 1261 & 1839 & 2051 & 1454 & 519 & 741 & 809 & 854 & 692 & 755 & 652 & 907 \\
\hline \multicolumn{16}{|l|}{ mineral soil } \\
\hline $\mathrm{C}_{\text {org }}$ & {$\left[\mathrm{mol} \mathrm{m}^{-2}\right]$} & 1692 & 1129 & 1519 & 1089 & 1312 & 1331 & 845 & 1343 & 1063 & 974 & 991 & 1365 & 1096 & 844 \\
\hline $\mathrm{N}_{\mathrm{t}}$ & {$\left[\mathrm{mol} \mathrm{m}^{-2}\right]$} & 82 & 50 & 78 & 41 & 51 & 68 & 54 & 63 & 60 & 51 & 42 & 58 & 54 & 48 \\
\hline $\mathrm{C} / \mathrm{N}$ & {$\left[\mathrm{mol} \mathrm{mol}^{-1}\right]$} & 21.1 & 23.3 & 20.3 & 25.7 & 26.4 & 19.7 & 17.1 & 20.9 & 19.3 & 19.1 & 23.0 & 23.8 & 20.1 & 18.6 \\
\hline $\mathrm{pH}\left(\mathrm{H}_{2} \mathrm{O}\right)$ & & 4.0 & 3.8 & 4.2 & 3.6 & 4.1 & 4.4 & 4.5 & 5.6 & 4.6 & 5.3 & 3.9 & 4.0 & 4.6 & 4.6 \\
\hline $\mathrm{P}_{\mathrm{a}}$ & {$\left[\mathrm{mmol} \mathrm{m}{ }^{-2}\right]$} & 1099 & 497 & 530 & 482 & 491 & 1469 & 271 & 318 & 802 & 913 & 214 & 1664 & 1510 & 891 \\
\hline CEC & {$\left[\mu \mathrm{mol}_{\mathrm{c}} \mathrm{g}^{-1}\right]$} & 116 & 70 & 73 & 80 & 64 & 207 & 68 & 230 & 70 & 103 & 30 & 78 & 42 & 34 \\
\hline $\mathrm{Ca}_{\mathrm{ex}}$ & {$\left[\mathrm{mol}_{\mathrm{c}} \mathrm{m}^{-2}\right]$} & 10.6 & 0.6 & 5.2 & 5.6 & 1.9 & 28.0 & 10.6 & 39.0 & 3.9 & 20.6 & 1.9 & 9.0 & 5.3 & 5.6 \\
\hline$M g_{\mathrm{ex}}$ & {$\left[\mathrm{mol}_{\mathrm{c}} \mathrm{m}^{-2}\right]$} & 2.1 & 0.2 & 5.5 & 0.4 & 0.4 & 5.0 & 0.7 & 1.1 & 5.5 & 3.4 & 0.0 & 0.6 & 0.8 & 0.8 \\
\hline $\mathrm{K}_{\mathrm{ex}}$ & {$\left[\mathrm{mol}_{\mathrm{c}} \mathrm{m}^{-2}\right]$} & 0.6 & 0.7 & 0.4 & 0.4 & 1.5 & 0.9 & 1.5 & 1.0 & 1.0 & 2.2 & 0.5 & 1.3 & 1.1 & 0.8 \\
\hline Base saturation & [\%] & 48 & 15 & 45 & 36 & 26 & 64 & 29 & 92 & 48 & 91 & 21 & 39 & 45 & 56 \\
\hline $\mathrm{Al}_{\mathrm{ex}}$ & {$\left[\mathrm{mol}_{\mathrm{c}} \mathrm{m}^{-2}\right]$} & 20 & 6 & 14 & 12 & 12 & 14 & 41 & 16 & 36 & 8 & 11 & 16 & 8 & 3 \\
\hline
\end{tabular}

$\mathrm{a}=$ plant-available content, ex = exchangeable content, org = organic content, $\mathrm{t}=$ total content 
Table A2. Results of correlation analyses of organic layer properties of 14 beech stands on Triassic sandstone along a precipitation gradient in central Germany. Values given are

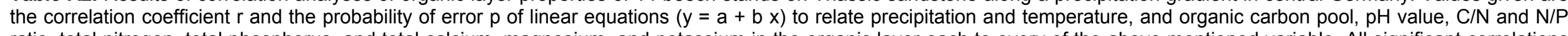
ratio, total nitrogen, total phosphorus, and total calcium, magnesium, and potassium in the organic layer each to every of the above mentioned variable. All significant correlations $(\mathrm{p} \leq 0.05)$ are in bold. For units refer to table A1.

\begin{tabular}{|c|c|c|c|c|c|c|c|c|c|c|c|c|c|c|c|c|}
\hline & \multicolumn{16}{|c|}{ Organic layer } \\
\hline & \multicolumn{2}{|c|}{$\mathrm{C}_{\text {org }}$} & \multicolumn{2}{|c|}{$\mathrm{pH}\left(\mathrm{H}_{2} \mathrm{O}\right)$} & \multicolumn{2}{|c|}{$\mathrm{C} / \mathrm{N}$} & \multicolumn{2}{|c|}{$\mathrm{N}_{\mathrm{t}}$} & \multicolumn{2}{|c|}{$P_{t}$} & \multicolumn{2}{|c|}{$\mathrm{N}_{\mathrm{t}} / \mathrm{P}_{\mathrm{t}}$} & \multicolumn{2}{|c|}{$(\mathrm{Ca}+\mathrm{Mg}+\mathrm{K})_{t}$} & \multicolumn{2}{|c|}{$\mathrm{C} / \mathrm{K}$} \\
\hline & $r$ & $\mathrm{p}$ & $r$ & $p$ & $r$ & $\mathrm{p}$ & $r$ & $\mathrm{p}$ & $r$ & $\mathrm{p}$ & $r$ & $\mathrm{p}$ & $r$ & $\mathrm{p}$ & & \\
\hline Precipitation & 0.52 & 0.03 & -0.50 & 0.03 & -0.41 & 0.07 & 0.52 & 0.03 & 0.45 & 0.05 & 0.58 & 0.01 & 0.44 & 0.06 & 0.64 & 0.01 \\
\hline Temperature & -0.38 & 0.09 & 0.27 & 0.17 & 0.33 & 0.13 & -0.40 & 0.08 & -0.35 & 0.11 & -0.34 & 0.12 & -0.36 & 0.10 & -0.30 & 0.15 \\
\hline \multicolumn{17}{|l|}{ Organic layer } \\
\hline $\mathrm{C}_{\text {org }}$ & & & -0.66 & 0.01 & -0.50 & 0.03 & 1.00 & $<0.001$ & 0.97 & $<0.001$ & 0.61 & 0.01 & 0.65 & 0.01 & 0.54 & 0.02 \\
\hline $\mathrm{pH}\left(\mathrm{H}_{2} \mathrm{O}\right)$ & & & & & 0.27 & 0.18 & -0.65 & 0.01 & -0.63 & 0.01 & -0.42 & 0.06 & -0.16 & 0.29 & -0.67 & 0.004 \\
\hline $\mathrm{C} / \mathrm{N}$ & & & & & & & -0.54 & 0.02 & -0.48 & 0.04 & -0.66 & 0.01 & -0.46 & 0.05 & -0.35 & 0.11 \\
\hline $\mathrm{N}_{\mathrm{t}}$ & & & & & & & & & 0.97 & $<0.001$ & 0.63 & 0.01 & 0.64 & 0.01 & 0.54 & 0.02 \\
\hline $\mathrm{P}_{\mathrm{t}}$ & & & & & & & & & & & 0.42 & 0.07 & 0.68 & 0.003 & 0.41 & 0.07 \\
\hline $\mathrm{N}_{\mathrm{t}} / \mathrm{P}_{\mathrm{t}}$ & & & & & & & & & & & & & 0.31 & 0.14 & 0.69 & 0.003 \\
\hline$(\mathrm{Ca}+\mathrm{Mg}+\mathrm{K})_{\mathrm{t}}$ & & & & & & & & & & & & & & & -0.04 & 0.45 \\
\hline
\end{tabular}


Table A3. Results of correlation analyses of organic layer and soil properties (mineral soil, $0-20 \mathrm{~cm}$ ) of 14 beech stands on Triassic sandstone along a precipitation gradient in central Germany. Values given are the correlation coefficient $r$ and the probability of error $p$ of linear equations $(y=a+b x)$ to relate precipitation and temperature, and organic carbon pool, $\mathrm{pH}$ value, $\mathrm{C} / \mathrm{N}$ and N/P ratio, total nitrogen, total phosphorus, and total calcium, magnesium, and potassium in the organic layer, organic carbon pool, $\mathrm{pH}$ value, $\mathrm{C} / \mathrm{N}$ ratio, total nitrogen, plant-available phosphorus, cation exchange capacity (CEC), and base saturation in the mineral soil each to every of the above mentioned variable. All significant correlations $(p \leq 0.05)$ are in bold. For units refer to table A1.

\begin{tabular}{|c|c|c|c|c|c|c|c|c|c|c|c|c|}
\hline & \multicolumn{12}{|c|}{ Mineral soil } \\
\hline & \multicolumn{2}{|c|}{$\mathrm{C}_{\text {org }}$} & \multicolumn{2}{|c|}{$\mathrm{pH}\left(\mathrm{H}_{2} \mathrm{O}\right)$} & \multicolumn{2}{|c|}{$\mathrm{C} / \mathrm{N}$} & \multicolumn{2}{|c|}{$\mathrm{P}_{\mathrm{a}}$} & \multicolumn{2}{|c|}{ CEC } & \multicolumn{2}{|c|}{ Base saturation } \\
\hline & $r$ & $\mathrm{p}$ & $r$ & $\mathrm{p}$ & $r$ & $\mathrm{p}$ & $r$ & $\mathrm{p}$ & $r$ & $\mathrm{p}$ & $r$ & $\mathrm{p}$ \\
\hline Precipitation & 0.60 & 0.01 & -0.47 & 0.04 & 0.34 & 0.12 & -0.24 & 0.20 & 0.22 & 0.23 & -0.29 & 0.15 \\
\hline Temperature & -0.53 & 0.03 & -0.002 & 0.50 & -0.10 & 0.36 & 0.03 & 0.45 & -0.50 & 0.03 & -0.10 & 0.36 \\
\hline \multicolumn{13}{|l|}{ Organic layer } \\
\hline $\mathrm{C}_{\text {org }}$ & 0.15 & 0.31 & -0.49 & 0.04 & 0.76 & $<0.001$ & -0.28 & 0.16 & -0.24 & 0.21 & -0.54 & 0.02 \\
\hline $\mathrm{pH}\left(\mathrm{H}_{2} \mathrm{O}\right)$ & -0.42 & 0.07 & 0.51 & 0.03 & -0.74 & 0.001 & 0.35 & 0.11 & 0.09 & 0.38 & 0.50 & 0.03 \\
\hline $\mathrm{C} / \mathrm{N}$ & -0.19 & 0.26 & 0.72 & 0.002 & -0.36 & 0.10 & -0.17 & 0.28 & 0.22 & 0.23 & 0.63 & 0.01 \\
\hline $\mathrm{N}_{\mathrm{t}}$ & 0.15 & 0.31 & -0.50 & 0.03 & 0.75 & 0.001 & -0.27 & 0.18 & -0.23 & 0.21 & -0.55 & 0.02 \\
\hline $\mathrm{P}_{\mathrm{t}}$ & 0.20 & 0.26 & -0.46 & 0.05 & 0.76 & 0.001 & -0.22 & 0.23 & -0.27 & 0.18 & -0.47 & 0.05 \\
\hline $\mathrm{N}_{\mathrm{t}} / \mathrm{P}_{\mathrm{t}}$ & 0.03 & 0.46 & -0.59 & 0.01 & 0.40 & 0.08 & -0.26 & 0.19 & -0.05 & 0.43 & -0.66 & 0.01 \\
\hline$(\mathrm{Ca}+\mathrm{Mg}+\mathrm{K})_{\mathrm{t}}$ & 0.23 & 0.22 & -0.33 & 0.12 & 0.61 & 0.01 & -0.10 & 0.37 & 0.09 & 0.38 & -0.13 & 0.33 \\
\hline $\mathrm{C} / \mathrm{K}$ & 0.23 & 0.22 & -0.46 & 0.05 & 0.35 & 0.11 & -0.37 & 0.10 & -0.19 & 0.26 & -0.53 & 0.03 \\
\hline \multicolumn{13}{|l|}{ Mineral soil } \\
\hline $\mathrm{C}_{\text {org }}$ & & & -0.17 & 0.28 & 0.30 & 0.15 & 0.27 & 0.18 & 0.44 & 0.06 & 0.09 & 0.38 \\
\hline $\mathrm{pH}\left(\mathrm{H}_{2} \mathrm{O}\right)$ & & & & & -0.58 & 0.01 & $<0.01$ & 0.50 & 0.49 & 0.04 & 0.86 & $<0.001$ \\
\hline $\mathrm{C} / \mathrm{N}$ & & & & & & & -0.13 & 0.33 & -0.13 & 0.33 & -0.46 & 0.05 \\
\hline $\mathrm{P}_{\mathrm{a}}$ & & & & & & & & & 0.10 & 0.36 & 0.22 & 0.23 \\
\hline CEC & & & & & & & & & & & 0.66 & 0.01 \\
\hline
\end{tabular}




\section{Herzlich bedanken möchte ich mich bei}

Christoph Leuschner, der mich in angeregten Diskussionen immer wieder neu zu motivieren wusste und der für die Finanzierung dieser Arbeit bis zum Ende Sorge getragen hat - Frank Thomas für die Übernahme des Korreferats - Dirk Gansert, Hermann Jungkunst und Astrid Rodriguez für ihre hilfreichen Verbesserungsvorschläge - meiner Zimmergenossin Doris Burk, mit der ich manch vergnügliche Stunde verbracht habe · Jasmin Lendzion für die unterstützenden Worte, wenn es nötig war, und die Cocktails zu den anderen Zeiten · Marieke Harteveld für die gemeinsam verbrachte Endphase - Choimaa Duja für die schöne neue Zimmergemeinschaft - Heinz Coners, der mir bei etlichen technischen Problemchen immer mit einem Lächeln begegnete - Vanessa Bremerich und Malte Unger, die mir beim Armbrustschießen geholfen haben · Jasmin Schumann und Marcel Tillmann, die für mich die Bomben in Wallung gehalten haben - Raphael Fritz für seine Selbstständigkeit - Mechthild Stange für ihre einfühlsame und zugleich zupackende Art · Jutta Czernitzki, Irmgard Gerstmann, Marianne Gscheidlen, Uta Nüsse-Hahne und Ute Schlonsog für unzählige Dinge · Heiko Eichner, ohne dessen Hilfe das Experiment im Wurzellabor nicht so perfekt auf- und wieder abgebaut worden wäre · Regina Helwig, Gabi Kuchenbuch, Dirk Deilke und Uli Werder, die mir bei etlichen Einsätzen im Wald und im Wurzellabor geholfen haben;

Frau Schlegel-Starrmann und der Deutschen Bundesstiftung Umwelt, die meine Dissertation, aber auch meinen Auslandsaufenthalt in den USA finanziell unterstützt haben - Herrn Brode und Herrn Bauer vom Forstamt Ziegelroda; Herrn Schulz, Frau Becker und Frau Wenzel vom Forstamt Oldisleben; Herrn Fix, Herrn Lindner, Herrn Lucke und Herrn Klüßendorf vom Forstamt Sondershausen; Herrn Hartmann und Herrn Kohlstedt vom Forstamt Leinefelde; Herrn Ils, Herrn Niephagen und Herrn Brüggemann vom Forstamt Bleicherode; Herrn Frerk und Herrn Beck vom Forstamt Reinhausen; Herrn Müller, Herrn Kohlhoff und Herrn Martin vom Forstamt Kattenbühl; Herrn Beyer und Herrn Schröder vom Forstamt Bramwald; Herrn Humbert von der Revierförsterei Westerhofen; Herrn Kraft und Herrn Engel vom Forstamt Dassel und Herrn von Prollius, Herrn Hennecke und Herrn Quast vom Forstamt Neuhaus, die mir die Forschung in ihren Wäldern ermöglicht haben;

Marc für die erste von inm entdeckte Wurzel im Wurzellabor und vieles mehr - Katha, die mir gerade in der schwierigen Anfangszeit zur Seite gestanden hat - Constanze, die mir zuliebe unseren gemeinsamen Irlandurlaub immer wieder verschoben hat · allen Freunden, die ich insbesondere in der letzten Zeit viel zu sehr vernachlässigen musste;

meinem Bruder Lars, der mir den Kopf immer wieder gerade rückt und meinen Blick für die wesentlichen Dinge schärft - meiner Mutter, die immer für mich da ist und meinem Vater, der die Liebe zur Natur in mir geweckt hat. 


\section{Personal Data}

Date of birth

28 February 1975

Place of birth

Göttingen

Citizenship

German

\section{Education}

Research visit at the Pennsylvania State University, USA

Department of Horticulture, Prof. Dr. D. Eissenstat

Grant by the German Federal Environmental Foundation (DBU)

2003-2007 PhD candidate at the Georg-August-University of Göttingen, Department of Plant Ecology, Prof. Dr. Ch. Leuschner

Grant by the German Federal Environmental Foundation (DBU)

2002

Degree in biology (Diplom-Biologin)

Research topic of the diploma thesis: ,Jährlicher Nährstoffrückfluss mit der

Blattstreu in Buchenwaldökosystemen in Abhängigkeit vom boden-

chemischen Zustand'

1997-1998 Exchange student of biology at the University of Birmingham, Great Britain Grant by the German Academic Foreign Office (DAAD: ERASMUS)

1995-2002 Student of biology at the Georg-August-University of Göttingen, Main subject botany (with a focus on plant ecology)

Additional subjects forest pedology and microbiology

1994-1995 Voluntary year of community service at the ,Self-help of Physically Handicapped Persons' in Göttingen 